DOUGLAS PIGOZZI

POR QUE LER HÉCTOR OESTERHELD? A SOCIEDADE LATINO-AMERICANA ENTRE AS DÉCADAS DE 1950 E 1970 VISTA PELOS QUADRINHOS

São Paulo

2019 


\title{
POR QUE LER HÉCTOR OESTERHELD? A SOCIEDADE \\ LATINO-AMERICANA ENTRE AS DÉCADAS DE 1950 E 1970 VISTA PELOS QUADRINHOS
}

\author{
Versão corrigida \\ (Versão original disponível na Biblioteca da ECA/USP) \\ Tese apresentada à Escola de \\ Comunicações e Artes da \\ Universidade de São Paulo, como \\ exigência parcial para obtenção do \\ título de Doutor em Ciências da \\ Comunicação. \\ Área de concentração: Interfaces \\ Sociais da Comunicação. \\ Orientador: Professor Doutor \\ Waldomiro Vergueiro.
}

São Paulo

2019 


\section{Agradecimentos}

Nesses mais de vinte anos estudando na Universidade de São Paulo, devo agradecimentos, em primeiro lugar, ao Professor Doutor Waldomiro Vergueiro, pois foi com ele que dei os meus primeiros passos como pesquisador, na elaboração de um trabalho de conclusão de curso, sob sua orientação. Posteriormente, também me acolheu como orientando no Mestrado e no Doutorado, na área das Interfaces Sociais da Comunicação.

Ressalto também que durante esses anos em que trabalhamos juntos, sempre me atendeu gentilmente, estando, em todos os momentos, disponível para o diálogo e, além disso, bem-humorado.

Também contribuiu decisivamente para que eu tivesse acesso aos textos teóricos para a realização destes dois textos científicos.

Com isso, tive a oportunidade de trabalhar com um profissional que estuda os quadrinhos pelas mais diversas temáticas e também pelas mais diferentes perspectivas, há mais de trinta e cinco anos. Não tenho palavras que possam expressar a minha gratidão.

Também agradeço ao Miguel Angel Foncueva, um especialista sobre as histórias em quadrinhos argentinas e as obras de Héctor Germán Oesterheld, que me deu várias informações importantes para o desenvolvimento desta tese de Doutorado, as quais, provavelmente, somente ele poderia me fornecer.

Entre os vários motivos de sua relevância para o desenvolvimento desta pesquisa, podem ser citados seis: pelo fato de ser argentino; ser profundo conhecedor da cultura desse país, tendo, inclusive o título de Mestre em Cultura Argentina pelo INAP - Instituto de la Administracion Publica; por ter vivenciado fatos históricos da maior importância para a Argentina e para a América Latina, como a Juventude Peronista, os Montoneros e também o período do terrorismo de Estado na Argentina, durante a ditadura do general Jorge Rafael Videla; por seu trabalho realizado com o patrimônio cultural e as histórias em quadrinhos na Biblioteca Nacional da Argentina; pelo fato de ser um profundo conhecedor da obra de Héctor Germán Oesterheld, tema com o qual trabalha há mais de vinte anos; além de possuir uma das principais coleções argentinas da produção quadrinística oesterheldiana. 
Além desses motivos, esteve sempre disponível para me auxiliar, respondendo as minhas dezenas e dezenas de perguntas, sempre de modo gentil e paciente. Além disso, me indicou diversas fontes de informação que foram úteis para a realização desta tese, o que incluiu tanto filme, como livro e também quadrinhos. Também não tenho palavras para expressar a minha gratidão. E, por fim, ainda tive o prazer de ter, com ele, escrito um artigo que foi aprovado para constar nos anais de um dos eventos mais importantes da área, no Brasil.

Agradeço também ao pesquisador Sebastián Gago, da Faculdade de Ciências da Comunicação da Universidade Nacional de Córdoba, que se colocou à disposição para auxiliar o desenvolvimento final desta tese.

Lembro de modo bastante positivo também dos colegas pesquisadores do Observatório de Histórias em Quadrinhos da Escola de Comunicações e Artes da Universidade de São Paulo, tanto pelas discussões acadêmicas como também pelo apoio para a realização das Jornadas Internacionais de Histórias em Quadrinhos.

Além disso, lembro da importância das disciplinas que cursei durante o Mestrado e o Doutorado, o que auxiliou a minha formação acadêmica. Desse modo, agradeço aos Professores Doutores Anderson Vinicius Romanini, Celso Frederico, Lucilene Cury, Maria Cristina Castilho Costa, Sandra Reimão e Waldomiro Vergueiro.

Por fim, agradeço aos Professores Doutores Mauro Wilton de Sousa, Sandra Reimão e Waldomiro Vergueiro, docentes que estiveram presentes no exame de qualificação desta tese, pelas problematizações sugeridas e por apontarem linhas de pesquisas para a continuação deste estudo. 


\title{
Resumo
}

Discute o autoritarismo na América Latina entre as décadas de 1950 e 1970, por meio das histórias em quadrinhos do roteirista argentino Héctor Germán Oesterheld. O objetivo é refletir sobre as possibilidades de comunicação para uma conscientização social e política e um maior desenvolvimento moral dos leitores com o uso dos quadrinhos, em função de seus vários recursos de linguagem. A técnica de investigação é a interpretação de bibliografias que enfocam as diferentes perspectivas sobre as histórias em quadrinhos e acerca do autoritarismo do Poder Público, o que inclui o fato histórico e político das ditaduras militares, que favoreceram relações sociais autoritárias, e também a resistência das sociedades civis latino-americanas em relação a esses governos.

Palavras-chave: América Latina; Comunicação; Histórias em quadrinhos; Oesterheld; Sociologia Política; Sociologia da Cultura.

\begin{abstract}
Discusses authoritarianism in Latin America between the 1950s and 1970s, through the comic books of argentine writer Héctor Germán Oesterheld. The objective is to reflect on the possibilities of communication for a social and political awareness and a greater moral development of the readers with the use of comics, due to its various language resources. The research technique is the interpretation of bibliographies that focus on the different perspectives on comics and on the authoritarianism of the Public Power, which includes the historical and political fact of the military dictatorships, which favored authoritarian social relations, as well as the resistance of Latin American civil societies in relation to these governments.
\end{abstract}

Keywords: Latin America; Communication; Comics; Oesterheld; Political Sociology; Sociology of Culture. 


\section{Lista de ilustrações}

Figura 1 - Capa de um exemplar da revista Caras y Caretas extraída do livro de BONA, Luigi; GIUFFRIDA, Sergio (Ed.). Historietas: storia, personaggi e percorsi del fumetto latinoamericano. Milano: Gabriele Mazzotta, 1997 (p. 17).

Figura 2 - Capa de álbum. QUINO. Toda Mafalda. São Paulo: Martins Fontes, 2010.

Figura 3 - Capa de álbum. QUINO. Mafalda inédita. São Paulo: Martins Fontes, 2013.

Figura 4 - Tira de história em quadrinhos extraída do site Arquivo de llustración Argentina. Site: https://ilustracion.fadu.uba.ar/2015/11/08/alberto-broccoli/.

Figura 5 - Capa de um exemplar da revista Satiricón extraída do site Pasado en letras. Site: http://www.pasadoenletras.com/2014/04/satiricon-diciembrede-1975.html.

Figura 6 - Capa de um exemplar da revista Skorpio extraída do Site Arquivo de Ilustración Argentina. Site: https://ilustracion.fadu.uba.ar/2016/06/03/revista-skorpio/.

Figura 7 - Capa de um exemplar da revista Fierro extraída do livro de BONA, Luigi; GIUFFRIDA, Sergio (Ed.). Historietas: storia, personaggi e percorsi del fumetto latinoamericano. Milano: Gabriele Mazzotta, 1997 (p. 21).

Figura 8 - Capa de revista. MARTINI, Claudio Roberto; SASTURAIN, Juan (Org.). Fierro Brasil no 1: antologia de historietas de revista argentina Fierro e quadrinhos brasileiros. Campinas, SP: Zarabatana Books, 2011.

Figura 9 - Capa de revista. MARTINI, Claudio Roberto; SASTURAIN, Juan (Org.). Fierro Brasil no 2: antologia de historietas de revista argentina Fierro e quadrinhos brasileiros. Campinas, SP: Zarabatana Books, 2012.

Figura 10 - Figura de álbum. MARTINI, Claudio Roberto; SASTURAIN, Juan (Org.). Fierro Brasil no 2: antologia de historietas de revista argentina Fierro e quadrinhos brasileiros. Campinas, SP: Zarabatana Books, 2012 (p. 5).

Figura 11 - Capa de álbum. REYES, Carlos; ELGUETA, Rodrigo. Los Años de Allende. Santiago: Hueders, 2015.

Figura 12 - Figura de álbum. REYES, Carlos; ELGUETA, Rodrigo. Los Años de Allende. Santiago: Hueders, 2015 (p. 113).

Figura 13 - Figura de álbum. REYES, Carlos; ELGUETA, Rodrigo. Los Años de Allende. Santiago: Hueders, 2015 (p. 114). 
Figura 14 - Figura de álbum. RODRÍGUEZ PINO. Anticristo. Santiago: Metales Pesados, 2017 (p. 18).

Figura 15 - Figura de álbum. RODRíGUEZ PINO. Anticristo. Santiago: Metales Pesados, 2017 (p. 18).

Figura 16 - Figura de álbum. RODRíGUEZ PINO. Anticristo. Santiago: Metales Pesados, 2017 (p. 18).

Figura 17 - Figura de álbum. RODRÍGUEZ PINO. Anticristo. Santiago: Metales Pesados, 2017 (p. 18).

Figura 18 - Capa de adaptação literária. PRIETO, Jenaro. El Socio. Santiago: Origo, 2017.

Figura 19 - Figura de álbum. PRIETO, Jenaro. El Socio. Santiago: Origo, 2017 (p. 2).

Figura 20 - Tira de história em quadrinhos extraída do site El Diario del Cuy. Site: https://elcuy.files.wordpress.com/2018/09/tiras-1416-y-1417-color.jpg.

Figura 21 - Capa de álbum. VILLAR, Alfredo; ROSSELL, Luis; COSSIO, Jesús. Sendero Luminoso: história de uma guerra suja. São Paulo: Veneta, 2016.

Figura 22 - Capa de adaptação literária. GUIMARÃES, Bernardo. A Escrava Isaura. São Paulo: Ática, 2010.

Figura 23 - Capa de adaptação literária. VON GOETHE, Johann Wolfgang. Fausto em quadrinhos. São Paulo: Peirópolis, 2017. (Clássicos em HQ, 16).

Figura 24 - Figura extraída do site Latino Weekly Review. Site: latinoweeklyreview.com/?attachment_id=292726.

Figura 25 - Exemplo de trabalho artístico de autor extraído do livro de BONA, Luigi; GIUFFRIDA, Sergio (Ed.). Historietas: storia, personaggi e percorsi del fumetto latinoamericano. Milano: Gabriele Mazzotta, 1997 (p. 80).

Figura 26 - Figura de personagem extraída do site Historieteca. Historieta argentina. Site: historieteca.com.ar/HGO/hgo.htm.

Figura 27 - Figuras de personagens extraídas do site Historieteca. Historieta argentina. Site: historieteca.com.ar/HGO/hgo.htm.

Figura 28 - Figuras de personagens extraídas do site Historieteca. Historieta argentina. Site: historieteca.com.ar/HGO/hgo.htm.

Figura 29 - Figura de álbum. OESTERHELD, Héctor Germán; BRECCIA, Alberto. Mort Cinder. Buenos Aires: Diario Clarín, 2004 (p. 181). 
Figura 30 - Capa de álbum. OESTERHELD, Héctor Germán; BRECCIA, Alberto; BRECCIA, Enrique. Che: os últimos dias de um herói. São Paulo: Conrad, 2008.

Figura 31 - Figura de álbum. OESTERHELD, Héctor Germán; BRECCIA, Alberto. El Eternauta. Buenos Aires: Ediciones de La Urraca, [19-] (p. 34).

Figura 32 - Figura de álbum. OESTERHELD, Héctor Germán; BRECCIA, Alberto. El Eternauta. Buenos Aires: Ediciones de La Urraca, [19-] (p. 38).

Figura 33 - Figura de álbum. OESTERHELD, Héctor Germán; BRECCIA, Alberto. El Eternauta. Buenos Aires: Ediciones de La Urraca, [19-] (p. 37).

Figura 34 - Figura de álbum. OESTERHELD, Héctor Germán; BRECCIA, Alberto. El Eternauta. Buenos Aires: Ediciones de La Urraca, [19-] (p. 63).

Figura 35 - Figura de álbum. OESTERHELD, Héctor Germán; BRECCIA, Alberto. El Eternauta. Buenos Aires: Ediciones de La Urraca, [19-] (p. 56).

Figura 36 - Figura de álbum. OESTERHELD, Héctor Germán; TRIGO, Gustavo. La Guerra de los Antartes. Buenos Aires: Colihue, 1998 (p. 15).

Figura 37 - Figura de álbum. OESTERHELD, Héctor Germán; TRIGO, Gustavo. La Guerra de los Antartes. Buenos Aires: Colihue, 1998 (p. 91).

Figura 38 - Capa de álbum. SANZ, Salvador. O Esqueleto: o início. Campinas, SP: Zarabatana Books, 2015.

Figura 39 - Capa de revista. HORA CERO SUPLEMENTO SEMANAL. Buenos Aires: Frontera, 1957. Figura cedida pelo colecionador e expositor Miguel Angel Foncueva.

Figura 40 - Capa de álbum. OESTERHELD, Héctor Germán; SOLANO LOPEZ, Francisco. O Eternauta. São Paulo: Martins Fontes, 2011.

Figura 41 - Figura de personagem extraída do site Historieteca. Historieta argentina. Site: historieteca.com.ar/HGO/hgo.htm.

Figura 42 - Figura de álbum. OESTERHELD, Héctor Germán; SOLANO LOPEZ, Francisco. O Eternauta. São Paulo: Martins Fontes, 2011 (p. 89).

Figura 43 - Figura de álbum. OESTERHELD, Héctor Germán; SOLANO LOPEZ, Francisco. O Eternauta. São Paulo: Martins Fontes, 2011 (p. 208).

Figura 44 - Figura de álbum. OESTERHELD, Héctor Germán; SOLANO LOPEZ, Francisco. O Eternauta. São Paulo: Martins Fontes, 2011 (p. 211).

Figura 45 - Figura de álbum. OESTERHELD, Héctor Germán; SOLANO LOPEZ, Francisco. O Eternauta. São Paulo: Martins Fontes, 2011 (p. 105). 
Figura 46 - Figura de álbum. OESTERHELD, Héctor Germán; SOLANO LOPEZ, Francisco. O Eternauta. São Paulo: Martins Fontes, 2011 (p. 172).

Figura 47 - Figura de álbum. OESTERHELD, Héctor Germán; SOLANO LOPEZ, Francisco. O Eternauta. São Paulo: Martins Fontes, 2011 (p.15).

Figura 48 - Figura de álbum. OESTERHELD, Héctor Germán; SOLANO LOPEZ, Francisco. O Eternauta. São Paulo: Martins Fontes, 2011 (p. 15).

Figura 49 - Figura de álbum. OESTERHELD, Héctor Germán; SOLANO LOPEZ, Francisco. O Eternauta. São Paulo: Martins Fontes, 2011 (p. 15).

Figura 50 - Figura de álbum. OESTERHELD, Héctor Germán; SOLANO LOPEZ, Francisco. O Eternauta. São Paulo: Martins Fontes, 2011 (p. 357).

Figura 51 - Capa de álbum. OESTERHELD, Héctor Germán; SOLANO LOPEZ, Francisco. O Eternauta II. São Paulo: Martins Fontes, 2013.

Figura 52 - Figura de álbum. OESTERHELD, Héctor Germán; SOLANO LOPEZ, Francisco. O Eternauta II. São Paulo: Martins Fontes, 2013 (p. 11).

Figura 53 - Figura de álbum. OESTERHELD, Héctor Germán; SOLANO LOPEZ, Francisco. O Eternauta II. São Paulo: Martins Fontes, 2013 (p. 12).

Figura 54 - Figura de álbum. OESTERHELD, Héctor Germán; SOLANO LOPEZ, Francisco. O Eternauta II. São Paulo: Martins Fontes, 2013 (p. 130).

Figura 55 - Figura de álbum. OESTERHELD, Héctor Germán; SOLANO LOPEZ, Francisco. O Eternauta II. São Paulo: Martins Fontes, 2013 (p. 74).

Figura 56 - Figura de álbum. OESTERHELD, Héctor Germán; SOLANO LOPEZ, Francisco. O Eternauta II. São Paulo: Martins Fontes, 2013 (p. 78).

Figura 57 - Figura de álbum. OESTERHELD, Héctor Germán; SOLANO LOPEZ, Francisco. O Eternauta II. São Paulo: Martins Fontes, 2013 (p. 78).

Figura 58 - Figura de álbum. OESTERHELD, Héctor Germán; SOLANO LOPEZ, Francisco. O Eternauta. São Paulo: Martins Fontes, 2011 (p. 11).

Figura 59 - Figura de álbum. OESTERHELD, Héctor Germán; SOLANO LOPEZ, Francisco. O Eternauta. São Paulo: Martins Fontes, 2011 (p. 12).

Figura 60 - Figura de álbum. OESTERHELD, Héctor Germán; SOLANO LOPEZ, Francisco. O Eternauta II. São Paulo: Martins Fontes, 2013 (p. 19).

Figura 61 - Figura de álbum. OESTERHELD, Héctor Germán; SOLANO LOPEZ, Francisco. O Eternauta II. São Paulo: Martins Fontes, 2013 (p. 19).

Figura 62 - Figura de álbum. OESTERHELD, Héctor Germán; SOLANO LOPEZ, Francisco. O Eternauta II. São Paulo: Martins Fontes, 2013 (p. 65). 
Figura 63 - Figura de álbum. OESTERHELD, Héctor Germán; SOLANO LOPEZ, Francisco. O Eternauta II. São Paulo: Martins Fontes, 2013 (p. 78).

Figura 64 - Figura de álbum. OESTERHELD, Héctor Germán; SOLANO LOPEZ, Francisco. O Eternauta II. São Paulo: Martins Fontes, 2013 (p. 63).

Figura 65 - Figura de álbum. OESTERHELD, Héctor Germán; SOLANO LOPEZ, Francisco. O Eternauta II. São Paulo: Martins Fontes, 2013 (p. 161).

Figura 66 - Figura de álbum. OESTERHELD, Héctor Germán; SOLANO LOPEZ, Francisco. O Eternauta II. São Paulo: Martins Fontes, 2013 (p. 169).

Figura 67 - Figura de álbum. OESTERHELD, Héctor Germán; SOLANO LOPEZ, Francisco. O Eternauta II. São Paulo: Martins Fontes, 2013 (p. 181).

Figura 68 - Figura extraída do site Globedia. El Diario colaborativo. Site: http://globedia.com/macrismo-desaparecer-eternauta-hipocresia-aparentepolitica. 


\section{Sumário}

Introdução

Capítulo 1: Os objetivos, a hipótese e os procedimentos de pesquisa 20

$\begin{array}{ll}1.1 \text { Objetivos } & 20\end{array}$

1.2 Hipótese 21

$\begin{array}{ll}1.3 \text { Procedimentos de pesquisa } & 22\end{array}$

Capítulo 2: As histórias em quadrinhos e as ciências da comunicação 24

2.1 Os quadrinhos como meio de comunicação de massa 24

2.2 Características das histórias em quadrinhos 29

Capítulo 3: Uma região sob o autoritarismo do Estado: percalços na América Latina

Capítulo 4: Panorama dos quadrinhos de crítica social e política na América Latina

55

Capítulo 5: Héctor Germán Oesterheld e a sua inovadora produção quadrinística

Capítulo 6: El Eternauta: uma análise política e social

129

6.1 Contexto da produção de El Eternauta e El Eternauta II 129

6.2 El Eternauta

6.3 El Eternauta II

Considerações finais

Referências, material quadrinístico e bibliografia complementar

Referências

Material quadrinístico

Bibliografia complementar 


\section{INTRODUÇÃO}

As histórias em quadrinhos têm uma das contribuições mais significativas, no interior da produção cultural do mundo contemporâneo, pelos seus vários recursos intrínsecos de linguagens (como o uso das imagens, das figuras de linguagem e dos textos, ao mesmo tempo) e, nas mais diversas áreas, como a cultura política, a divulgação científica, a educação e o entretenimento. Em função de seu trabalho único com as linguagens, os quadrinhos são um veículo de comunicação privilegiado para a construção (e reconstrução) dos imaginários de seu público leitor.

Em específico, nesta tese de Doutorado, o roteirista de histórias em quadrinhos escolhido para ter a sua obra analisada foi Héctor Germán Oesterheld. Tanto Campos (2008), como Montero (2013), chegam a mencionar que Oesterheld é considerado, no meio quadrinístico, o principal roteirista de histórias em quadrinhos da história argentina e latino-americana. Portanto, a escolha de trabalhar com a produção quadrinística de Oesterheld se deve a sua importância como produtor na área.

Além disso, Oesterheld teve participação ativa nos eventos culturais, literários e políticos da Argentina e também da América Latina. Dada a repercussão de sua obra, ele é, historicamente, uma das figuras politicamente mais relevantes do mundo quadrinístico.

Oesterheld foi também um dos responsáveis por um deslocamento na ênfase das histórias em quadrinhos, de uma produção mais voltada para o entretenimento em direção a um conteúdo mais adulto, amplo, denso, educativo, politizado, profundo e reflexivo, que problematiza os fatos sociais do mundo contemporâneo, em especial nas sociedades latino-americanas, num trabalho que envolve, inclusive, uma maior conscientização acerca do exercício da cidadania do público leitor. Posteriormente, nos anos 1980, outros quadrinhistas também seguiram esse percurso na Europa, como, por exemplo, o sérvio radicado francês Enki Bilal e o inglês Alan Moore, por meio de seus quadrinhos "A Feira dos Imortais", presente na Trilogia Nikopol, e $V$ de Vingança, respectivamente. 
Desse modo, entendemos que Oesterheld pode ser visto como um dos principais pensadores acerca dos problemas culturais, econômicos, políticos e sociais latino-americanos nas últimas décadas, pois sua produção quadrinística tem o mérito de retratar as mais diferentes complexidades humanas, além de também estudar e expor aos leitores diversos padrões de comportamento social, não ficando preso às percepções sectárias de alguma ideologia ou pensamento dominante de uma época, e expressando, desse modo, sua capacidade de crítica à sociedade contemporânea, de modo criativo e inovador para aquele momento histórico.

Suas histórias em quadrinhos têm significativo poder explicativo acerca das sociedades latino-americanas, incluindo a temática da ditadura militar, fato que ocorreu, ao longo do século $\mathrm{XX}$, em vários países desta região geográfica. Aborda de modo aprofundado a problemática do autoritarismo e da resistência da sociedade civil a este cenário político, com um trabalho de significativa criatividade e qualidade, fugindo do maniqueísmo simplista do bem contra 0 mal, então predominante no meio quadrinístico (ao menos na produção de quadrinhos da América Latina, influenciada pelos produtos de origem estadunidense).

Portanto, a produção quadrinística oesterheldiana apresenta ao público leitor contribuições da maior importância para os estudos acerca das memórias, dos espaços e dos tempos que envolvem contextos políticos e sociais da América Latina, trabalhando, desse modo, com a leitura das imagens e dos textos, em conjunto.

Com isso, os quadrinhos de Oesterheld constroem narrativas que auxiliam - leitor a ter uma visão mais ampla e aprofundada acerca dos problemas sociais do mundo moderno e, em específico da América Latina, como o autoritarismo do Estado. E, além disso, chegam a formular propostas de intervenções prática e viáveis, as quais são, por vezes, fortemente políticas, podendo ser utilizadas pelos membros e por organizações da sociedade civil.

Em função da extensão da produção quadrinística oesterheldiana e dos objetivos desta tese, foi preciso efetuar uma delimitação do objeto da pesquisa, 
buscando trabalhar, principalmente, com dois momentos diferentes da produção deste roteirista de quadrinhos.

Num primeiro momento, na segunda metade da década de 1950, Oesterheld como um roteirista de histórias em quadrinhos dos gêneros da aventura e da ficção científica; e num segundo momento, a partir da segunda metade dos anos 1960, Oesterheld fazendo uso de sua capacidade criativa para elaborar roteiros mais contextualizados com o cenário político latinoamericano. Para tanto, é de fundamental importância apresentar o contexto político da época: as ditaduras militares e o problema do autoritarismo do Estado, num cenário de lutas políticas entre diferentes classes sociais, com suas respectivas visões de mundo.

Em função desse recorte do objeto de pesquisa, foram escolhidas as histórias em quadrinhos El Eternauta (publicada, pela primeira vez, entre os anos de 1957 e 1959) e El Eternauta II (publicada pela primeira vez, entre os anos de 1976 e 1978). Ambas contam com roteiros de Héctor Germán Oesterheld e desenhos de Francisco Solano López.

Isso posto, nesta tese foi necessário trabalhar com três linhas diferentes de conhecimentos: os estudos sobre as histórias em quadrinhos, com as suas características peculiares de linguagem no interior da produção cultural do mundo moderno; uma análise sobre as ditaduras militares e o contexto político latino-americano das décadas de 1950, 1960 e 1970; além da proposta quadrinística inovadora de Oesterheld.

Desse modo, esta tese está estruturada em introdução; desenvolvimento (que abarca seis capítulos); considerações finais; além do último tópico que apresenta as referências, o material quadrinístico e a bibliografia complementar. A introdução desta pesquisa trata basicamente do roteirista escolhido para o estudo neste trabalho acadêmico, de suas obras e períodos analisados, além de uma justificativa da importância desta tese. Também apresenta a organização, em capítulos, desta monografia. 
O primeiro capítulo trata dos objetivos (geral e específicos), da hipótese, no âmbito de estudo da área das Ciências da Comunicação, além dos procedimentos de pesquisa utilizados neste estudo.

O segundo capítulo apresenta as histórias em quadrinhos, como um meio de comunicação de massa e as suas características intrínsecas no uso das mais diferentes linguagens, que as tornam diferenciadas em relação aos demais meios de comunicação, buscando também apresentar algumas características comuns entre os quadrinhos e alguns dos demais meios de comunicação de massa.

Basicamente, os filósofos trabalhados de modo crítico nesse capítulo desta tese, acerca da discussão sobre os meios de comunicação e, em específico, sobre a indústria cultural, foram Horkheimer e Adorno (por meio do livro escrito por ambos que foi traduzido para o português, datado de 2002, e em espanhol, publicado em 2009).

Em relação aos estudos das histórias em quadrinhos foram utilizados os textos de Alessandri (1997), Barbieri (2017), Gociol e Rosemberg (2003), Postema (2018), Ramos (2010), Santos e Vergueiro (em uma publicação que trata das linguagens dos quadrinhos, de 2015), Silva Junior (2017), além de outros dois textos de Vergueiro (sua dissertação de Mestrado, que trata dos quadrinhos como meio de comunicação de massa, de 1985, e de um livro sobre as pesquisas acadêmicas sobre histórias em quadrinhos, de 2017).

O terceiro capítulo cumpre a função de contextualizar tanto a problemática do autoritarismo na América Latina como o fato político das ditaduras militares. Com isso, apresenta a situação sócio-histórica que influenciou a produção de um conjunto relevante de histórias em quadrinhos voltadas para o tema da cultura política e da conscientização social do leitor, principalmente nos casos da Argentina, do Chile, do Peru, do Brasil, da Nicarágua e de Cuba.

Além disso, esse capítulo apresenta o momento histórico da produção quadrinística de Oesterheld: a segunda metade do século XX. Desse modo, esse capítulo trata das origens de temas que são importantes naquele contexto 
e que, até hoje, são problemáticos em vários aspectos da vida cotidiana dos indivíduos (e coletividades) da sociedade civil latino-americana.

Para tanto, foram analisadas as contribuições dos estudos de Applebaum (2004), Arendt (1989), Ayala Mora (2016), Bastos (2006), Cavalcante Neto (2013), Coggiola (2001), Collier e Sater (1998), Doucey (2009), Drinot (2017), Galeano (2001), Gillespie (1998), Invernizzi e Gociol (2003), López Romero (2016), Marx [1867] (2013), Milton (2017), Montero (2013), Nepomuceno (1985), Pigozzi (2011), Rénique (2009), Rodas Chaves (2016), Salina Cañas (2013), Tannenbaum (1975), Valladares e Berbel (1994), Vega Ugalde (2016), Winn (2010), Zimmermann (2006), além do filme Imagens do Estado Novo (2018).

O quarto capítulo trata da produção quadrinística latino-americana que, por circunstâncias culturais, econômicas e sociais, tem a função de desenvolver a educação política do leitor, focando, portanto, na temática da cultura política. Trabalha, desse modo, como sendo um capítulo que apresenta um contexto cultural no âmbito das histórias em quadrinhos latino-americanas e também os seus desdobramentos até o momento presente. Para tanto, refere-se a autores e produções que tenham conteúdo de crítica social e política. Além disso, dialoga fortemente com o capítulo anterior desta tese.

Em relação às histórias em quadrinhos sul-americanas, e, em específico os quadrinhos argentinos, foram trabalhados os textos dos pesquisadores CataláCarrasco, Drinot e Scorer (2017); Fossati (1997); Gociol e Rosemberg (2003); Montero (2013) e Silva Junior (2017). Também foi útil o livro de Barbieri (2017), que trata da linguagem dos quadrinhos, que foi influenciada pela produção argentina.

Os comentários apresentados nesta tese acerca dos quadrinhos chilenos contaram com as contribuições das análises de Andaur (2017); Berth (2017); o catálogo de revistas elaborado por Hasson (2014), bem como outro texto desse autor, um artigo sobre quadrinhos políticos chilenos, Hasson (2018); além de Ojeda (2018) e Olmedo Carrasco (2017). Também foi relevante o contexto histórico e social chileno fornecido pelo livro de Collier e Sater (1998). Devido a falta de publicações de histórias em quadrinhos chilenas no mercado editorial 
brasileiro, foi necessário ir para o Chile, na cidade de Santiago, durante o período desta pesquisa, para a aquisição de fontes primárias de pesquisa, 0 que ocorreu em junho de 2018.

Para as observações acerca dos quadrinhos peruanos, foram usadas as publicações de Drinot (2017), Pérez-del-Solar (2012) e Milton (2017). Em relação às histórias em quadrinhos brasileiras foram utilizadas as pesquisas de Silva Junior (2004) e Vergueiro (2017), que foram fundamentais para a elaboração desta etapa da tese. Ainda na América do Sul, na discussão sobre os quadrinhos bolivianos, foi útil o texto de Cuevas [entre 2007 e 2018] e, por fim, foi consultada, para o estudo das histórias em quadrinhos venezuelanas, a colaboração de Guerra (1997).

Na América Central, para o estudo dos quadrinhos nicaraguenses, foram estudados os textos dos pesquisadores Berth (2017) e Vallecillo (1984), além do contexto histórico e social fornecido pela publicação de Zimmermann (2006). Em relação aos quadrinhos cubanos, existiram as contribuições dos textos de Catalá-Carrasco (2017), Mogno (1997), Someillan (2005), além de um artigo, sobre a formação de um novo homem, escrito por Ernesto "Che" Guevara (2009).

$\mathrm{Na}$ América do Norte, na exposição acerca dos quadrinhos mexicanos, foram utilizadas as análises de Bartra (2009), Bona e Giuffrida (1997), Del Río Garcia (1984), Fernández L’Hoeste e Poblete (2009), Fossati e Rosso (1997), e também de Soto Díaz [entre 2008 e 2018].

O quinto capítulo trata da obra quadrinística de Oesterheld, apresentando sua formação acadêmica, o momento em que começou a atuar como roteirista de histórias em quadrinhos, os gêneros de quadrinhos com os quais trabalhava e suas principais obras como Rolo, el marciano adoptivo (em parceria com Francisco Solano López), além de Sherlock Time, Mort Cinder, Che e El Eternauta (em parceria com Alberto Breccia).

Também estuda a passagem do trabalho quadrinístico de Oesterheld, de um roteirista dos gêneros de aventura e ficção-científica, para um intelectual que escrevia roteiros mais politizados, a partir, principalmente, dos quadrinhos 
Che e El Eternauta (ambos na seguna metade da década de 1960, com desenhos de Alberto Breccia).

Nesse capítulo, foi imprescindível a biografia de Oesterheld escrita por Montero (2013) e o trabalho de contextualização histórica realizado por Gillespie (1998). Também foram consultadas e analisadas produções científicas de outros autores: Avila (2007), Balletta (2017), Campos (2008), Díaz [entre 2003 e 2018], Gago (2010), Gociol (2007), Gociol e Rosemberg (2003), Hasson (2014), José Muñoz (2013), Ortega (2017), Pablo Muñoz (2004), Saccomanno (2004), além de duas produções científicas de um mesmo autor: um artigo de Von Sprecher (2007) e um livro de Von Sprecher (2010), e também do livro Oesterheld en tercera persona (2008), uma edição coletiva da editora La Bañadera del Comic.

O sexto capítulo trata dos quadrinhos El Eternauta e El Eternauta II (ambos realizados em parceria com Francisco Solano López), o que envolve tanto o cenário político e social da produção dos quadrinhos El Eternauta e Eternauta II, como também uma análise dessas duas graphic novels. Busca estudar algumas das imagens presentes nessas obras e também expor e discutir acerca do discurso apresentado nesses quadrinhos, fazendo relações com os momentos históricos dessas narrativas: El Eternauta (final dos anos 1950) e El Eternauta II (final dos anos 1970).

Foram utilizados, para a redação desse capítulo, as contribuições teóricas dos autores Arendt (1989), Avila (2007), Campos (2008), Coggiola (2001), Fossati (1997), García (2012), Gillespie (1998), Montero (2013), Reati (2009), Terán (2010), e, como no capítulo anterior, de duas produções científica de um mesmo autor: um artigo de Von Sprecher (2007) e um livro de Von Sprecher (2010). Além disso, foram também utilizadas a publicação Oesterheld en tercera persona (2008), uma edição coletiva da editora La Bañadera del Comic, e o filme La Hora de los hornos: notas y testimonios sobre el colonialismo, la violencia y la liberación [200-].

Posteriormente, são apresentadas as considerações finais desta tese, com os resultados desta pesquisa acerca da produção quadrinística oesterheldiana (sua contextualização e sua posterior influência), além de suas relações com a 
liberdade de expressão, no âmbito dos estudos da Comunicação, da Sociologia e da Ciência Política. Entende-se os quadrinhos de Oesterheld como documentos culturais que auxiliam o público leitor a ter uma formação social e política melhor fundamentada acerca de questões históricas e atuais; nesse caso, em específico, na América Latina.

Ao final, são apresentadas as referências que foram utilizadas ao longo deste trabalho científico, dividido em três itens: as referências (citadas nesta tese), o material quadrinístico (utilizado e/ou citado), além da bibliografia complementar (não citadas nesta tese, mas que foram consultadas ao longo da pesquisa e foram fundamentais para este estudo). 


\section{OS OBJETIVOS, A HIPÓTESE E OS PROCEDIMENTOS DE PESQUISA}

\subsection{Objetivos}

O objetivo geral desta tese é a análise das obras do quadrinista argentino Héctor Germán Oesterheld, em particular as histórias em quadrinhos El Eternauta e El Eternauta II, que possuem desenhos de Francisco Solano López, fazendo uma relação com os eventos políticos ocorridos na América Latina durante as décadas de 1950 e 1970.

Naquele momento histórico ocorrem, em vários países latino-americanos, as ditaduras militares, regimes políticos que, ainda hoje, impactam de diversos modos nas sociedades latino-americanas. Com isso, busca-se refletir sobre situações que envolvem tanto o autoritarismo político como a problemática das disputas entre as classes sociais, no interior da sociedade contemporânea.

Como objetivos específicos, temos:

1) realizar uma contextualização das histórias em quadrinhos como meio de comunicação de massa, lembrando seu papel de relevância para uma reflexão mais crítica e densa sobre a realidade social e política das sociedades modernas;

2) apresentar a produção quadrinística de Oesterheld, como uma renovação das histórias em quadrinhos, em função de vários fatores, como um maior aprofundamento psicológico dos personagens e um trabalho com o senso crítico do leitor;

3) verificar a mudança da visão de mundo e de valores simbólicos de Oesterheld, ao longo de sua vida profissional, entre as décadas de 1950 e 1970, fato esse que impactou na sua produção de quadrinhos e que está ligada ao cenário político da América Latina e, em específico, da Argentina e do Chile (países nos quais Oesterheld trabalhou como roteirista de histórias em quadrinhos e nos quais teve papel relevante na produção quadrinística). 


\subsection{Hipótese}

A hipótese desta pesquisa é a de que as histórias em quadrinhos elaboradas pelo roteirista Oesterheld, durante as décadas de 1950 e 1970, constituem fonte da maior importância para a análise das temáticas sociais e políticas da América Latina, pois discutem, de modo inovador (para aquele momento histórico) e com alto patamar de complexidade e de problematização, várias das questões que até os dias atuais não foram resolvidas em parte significativa desta região geográfica. Desse modo, é possível afirmar que a produção quadrinística oesterheldiana apresenta, por meio de suas narrativas e histórias, temáticas e discussões que, por vezes, tratam de temas próprios da Ciência Política, da Comunicação, da Filosofia e da Sociologia.

Em específico, esta tese de Doutorado trata, principalmente, de sua produção quadrinística mais conhecida e relevante no mundo dos quadrinhos: El Eternauta, que foi realizada em parceria com o desenhista Francisco Solano López, em suas duas versões: El Eternauta (1957-1959) e El Eternauta II (1976-1978). É adequado lembrar que entre esses dois períodos foi publicada uma outra versão de El Eternauta, com roteiros de Oesterheld e desenhos de Alberto Breccia, no ano de 1969.

As duas histórias em quadrinhos elaboradas pela dupla Oesterheld/Solano López possuem significativa riqueza de linguagens, fazendo uso, ao mesmo tempo, das imagens, dos textos e das figuras de linguagens e atuam como um meio facilitador da comunicação, auxiliando na transmissão dos fluxos de mensagens, além de construir e (reconstruir) sentidos para o público leitor, produzindo informações de modo único, quando comparadas aos outros meios de comunicação de massa. Desse modo, esses quadrinhos têm a capacidade de "ampliar" as formas e as possibilidades de leitura, nesse caso, tanto escrita como icônica, trabalhando, em específico, com temáticas próprias da cultura política.

Portanto, fazendo uso dos quadrinhos é possível aprofundar a reflexão crítica sobre o mundo contemporâneo e, com isso, desenvolver um maior 
patamar de consciência acerca da complexidade da realidade social das sociedades latino-americana.

\subsection{Procedimentos de pesquisa}

A técnica de investigação foi a leitura e a interpretação de bibliografias que enfocam as diferentes visões sobre os quadrinhos como patrimônio cultural, o que inclui suas especificidades no interior dos meios de comunicação, além da literatura que trata sobre a problemática do autoritarismo, no contexto das ditaduras militares latino-americanas.

Para tanto, foi necessária uma pesquisa documental, que envolveu um levantamento da literatura acerca de quatro temas, principalmente: as histórias em quadrinhos como meio de comunicação de massa; um panorama históricosocial latino-americano sobre o autoritarismo do Poder Público; a produção quadrinística que trabalha com a crítica social e política na América Latina e também publicações que discutem a originalidade e a relevância dos quadrinhos de Oesterheld, o que inclui um debate que envolve uma possível formação (e transformação) da consciência social do público leitor destas histórias em quadrinhos.

Com isso, decidiu-se pela realização de um estudo de caso, dos quadrinhos El Eternauta e El Eternauta II, buscando identificar as relações com o autoritarismo do poder público, em dois momentos históricos diferentes: segunda metade dos anos 1950 e segunda metade dos anos 1970, entendendo essa problemática como um fenômeno político e sociológico.

Tal fato ocorre quando um indivíduo, ou uma fração de classe social, ou até mesmo uma classe social como um todo, exerce um controle sobre toda a sociedade, por meio de condutas autoritárias e repressivas, o que tangencia a discussão sobre o totalitarismo.

Para tanto, foi preciso trabalhar com a análise do discurso dos personagens das histórias em quadrinhos El Eternauta e El Eternauta II, pois essas mensagens expressam as linhas ideológicas e políticas de seus 
pensamentos, expondo, desse modo, os possíveis conflitos existentes entre diferentes grupos societários nessas histórias em quadrinhos que remetem a diversos cenários e problemáticas da realidade política daqueles momentos históricos, os quais, por vezes, ainda sem uma resolução adequada nos dias atuais.

Esses discursos apresentam argumentos que, potencialmente, têm a capacidade de persuadir os leitores, em termos de pensamentos e ações, para que ocorra um posicionamento desse público leitor em relação a algumas destas questões. 


\section{AS HISTÓRIAS EM QUADRINHOS E AS CIÊNCIAS DA COMUNICAÇÃO}

\subsection{Os quadrinhos como meio de comunicação de massa}

As diversas manifestações culturais que existem na sociedade contemporânea, como o cinema, as emissoras de rádio e de televisão, as histórias em quadrinhos, a internet, os jornais (eletrônicos e impressos), a literatura e o teatro, possuem características que as aproximam como meios de comunicação de massa e também aspectos que as diferenciam.

Essas manifestações culturais tornam-se meios de comunicação de massa quando o seu público é formado por um conjunto de indivíduos que não é segmentado, por exemplo, por condições psicológicas, ou por faixas etárias, ou mesmo por valores estéticos, sendo, com isso, constituído um grande público, ou uma "massa".

Em linhas gerais, é possível mencionar que essa "massa" é facilmente influenciada, tanto por manifestações culturais, como pelos mais diversos meios de comunicação, pois esse público possui um baixo patamar de autonomia e de reflexão crítica em relação aos fundamentos da sociedade contemporânea, sendo passível de fácil manipulação política e também de ser receptivo a uma obediência irrefletida.

Portanto, nesse contexto, os meios de comunicação possuem a capacidade de promover diferentes formas de "homogeneização cultural". Deve-se também ter em conta que, por vezes, alguns estratos sociais podem influenciar o que é veiculado por esses meios.

Esse segmento da indústria, entendido como "indústria cultural" não é neutra, estando imersa em um contexto mais amplo, que envolve a temática da ideologia, da política, dos valores sociais, e, consequentemente, da disputa pelo poder. Como lembra Vergueiro (1985):

A indústria cultural tende sempre a transmitir um conteúdo conservador e funciona como reforço das normas sociais pelo artifício de repeti-las até a exaustão. Quando a inculcamos de 
conservadora, não queremos com isto afirmar que não promova mudanças estilísticas; sabemos muito bem que ela contribuiu para diversas destas mudanças e as inovações estilísticas introduzidas pelo cinema, as histórias em quadrinhos e a televisão são muito eloquentes para serem esquecidas. No entanto, a ideologia da indústria cultural, em seu todo, é sempre conservadora porque a ela não interessam mudanças no sistema; qualquer mudança que arranhe mais que o superficial irá retirar dela a supremacia que exerce sobre as massas. É, portanto, alienatória, veiculando sempre padrões de conformismo ao mesmo tempo que finge divertir; reforçando normas sociais dominantes enquanto finge estar zombando delas, doutrinando o público para o consumo ao mesmo tempo que se faz passar por duradoura [...]". (VERGUEIRO, 1985, p. 49).

Tal contexto acaba por produzir (e reproduzir) tanto padrões culturais como ideologias, o que, no caso específico dos quadrinhos, já era estudado na década de 1980, também por Vergueiro (1985):

As histórias em quadrinhos produzidas com o intuito de serem consumidas em grande escala tendem a reproduzir os padrões norte-americanos de produção e funcionam como reduplicadores da ideologia que entra no país via histórias em quadrinhos "enlatadas". (VERGUEIRO, 1985, p. 169-170).

As teorias da industrialização da cultura, com a consequente formação da indústria cultural e da cultura de massa, envolve, por exemplo, a discussão do controle social, como uma forma de exercício do poder, por meio do conformismo e do entretenimento, com o consequente ocultamento dos conflitos estruturais próprios da sociedade contemporânea, e também uma possível padronização nas formas como são produzidos os bens culturais, elaboradas por Theodor Wiesengrund Adorno e Max Horkheimer, são analisadas, nesta tese, a partir de uma perspectiva crítica, pois os meios de comunicação de massa e, particularmente, as histórias em quadrinhos, podem ser úteis ao leitor para a formação de um pensamento mais complexo acerca da realidade cultural, social e política do mundo contemporâneo. Como exemplo, é possível problematizar o texto a seguir: 
A atrofia da imaginação e da espontaneidade do consumidor cultural de hoje não tem necessidade de ser explicada em termos psicológicos. Os próprios produtos [...] paralisam aquelas capacidades pela sua própria constituição objetiva. Eles são feitos de modo que a sua apreensão adequada exige, por um lado, rapidez de percepção, capacidade de observação e competência específica, e por outro é feita de modo a vetar, de fato, a atividade mental [...]. (HORKHEIMER; ADORNO, 2002, p. 16).

Uma possível crítica ao trecho citado de Adorno e Horkheimer, é o fato de que uma parcela significativa das produções culturais, mesmo produzidas em escala industrial, realizadas por diferentes meios de comunicação atua, justamente, no desenvolvimento da capacidade crítica, da fantasia e da imaginação do público leitor.

No cinema, por exemplo, pode-se ser mencionada a produção cinematográfica de Ingmar Bergman e Jean-Luc Godard; na literatura, por exemplo, Johann Wolfgang von Goethe (literatura clássica alemã) e do colombiano Mario Mendoza Zambrano (literatura contemporânea latinoamericana), nos quadrinhos, por exemplo, a produção quadrinística dos roteiristas Alan Moore, Enki Bilal e Héctor Germán Oesterheld e no teatro, por exemplo, as peças de Augusto Boal e Bertolt Brecht. Todos esses intelectuais compreenderam de modo profundo as relações sociais de seus momentos históricos e, além disso, criticaram esses padrões societários.

Os autores Horkheimer e Adorno, no texto "La Industria Cultural: llustración como engaño de masas", pertencente à obra Dialéctica de la Ilustración: fragmentos filosóficos (em português: Dialética do Esclarecimento: fragmentos filosóficos), chegam a mencionar que: "o empobrecimento dos materiais estéticos que a hoje mal velada identidade de todos os produtos da indústria cultural poderá triunfar abertamente". (HORKHEIMER; ADORNO, 2009, p. 169, tradução nossa) ${ }^{1}$.

Contudo, as histórias em quadrinhos, em função do uso dos seus recursos intrínsecos para a construção de uma narrativa, mesclando as imagens e os

\footnotetext{
${ }^{1}$ El empobrecimiento de los materiales estéticos que la identidad hoy apenas velada de todos los produtos de la indústria cultural podrá mañana triunfar abiertamente.
} 
textos, além de um leque significativo de figuras de linguagens, em conjunto, podem apresentar diversas combinações de produtos culturais que favorecem a criatividade e também as inovações estéticas. E, ao mesmo tempo, o desenvolvimento de uma formação moral e política do receptor dessas mensagens, auxiliando o leitor a analisar e criticar os atuais padrões de sociabilidade. Nesse sentido, é possível afirmar que os quadrinhos, como bens culturais, têm, potencialmente, a capacidade de desenvolver e transmitir determinadas narrativas de forma mais complexa ao público leitor.

Com isso, a afirmação de que "a indústria cultural tende a apresentar-se como um conjunto de proposições protocolares e, portanto, apenas como um profeta irrefutável do existente" (HORKHEIMER; ADORNO, 2009, p. 192, tradução nossa $)^{2}$ é problemática, uma vez que, nem sempre, os bens culturais produzidos por esse segmento industrial atuam em favor do conformismo do seu público. Inclusive, nesta tese, são estudadas histórias em quadrinhos que, por vezes, cumprem um papel até mesmo inverso a esse. Pode-se dizer ainda que já há algum tempo, com o aumento da complexidade do mercado editorial das histórias em quadrinhos, ocorre uma renovação das publicações e, consequentemente, do consumo desses quadrinhos, diversificando também as possibilidades de estudos que envolvem essas histórias. Lembrando, novamente, Vergueiro (2017):

A boa notícia é que as obras que fazem avançar a lingugem quadrinística já não se situam somente no âmbito do quadrinho alternativo ou underground, como antes se pensava. Cada vez mais, é possível encontrar no contexto de quadrinhos mainstream obras que, embora tratando de temáticas aparentemente padronizadas, re-elaboram a linguagem e influem significativamente em seu aprimoramento. $E$ isso ocorre com frequência cada vez maior. (VERGUEIRO, 2017, p. 5).

Deve-se também sempre levar em consideração o histórico de produção deste suporte informacional, de acordo com cada país. Como exemplo, tanto o

\footnotetext{
${ }^{2}$ La industria cultural tiende a presentarse como um conjunto de proposiciones protocolaris y así justamente como profeta irrefutable de lo existente.
} 
monumental trabalho de mais de seiscentas páginas de Gociol e Rosemberg (2003), como os textos de Alessandri (1997), Ramos (2010) e de Silva Junior (2017), mencionam o fato de que as histórias em quadrinhos se consolidaram, na Argentina, num primeiro momento, nas revistas, o que difere dos Estados Unidos, onde as primeiras publicações ocorreram nos jornais. Silva Junior (2017) chega a mencionar algumas destas revistas argentinas, entre as quais: Caras y Caretas (que aparece ao público leitor em 1898), PBT e El Hogar (ambas lançadas no mercado em 1904). Abaixo, na figura um, é apresentada uma capa da revista Caras y Caretas, de 1912.

Fig. 1 - Capa de uma revista Caras y Caretas.

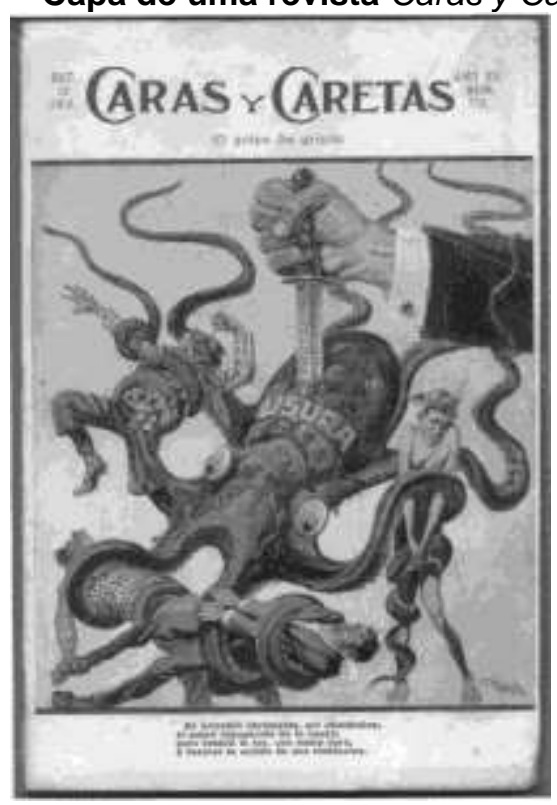

Fonte: acervo do orientador desta tese.

Desse modo, os quadrinhos são produções histórico-sociais que refletem e, além disso, também dialogam e podem questionar acerca dos diversos cenários culturais e políticos em seu universo ficcional. Ou seja: os quadrinhos podem ser entendidos como uma expressão complexa, crítica e figurativa de uma determinada realidade $\mathrm{e}$, desse modo, auxiliam na construção (e conformação) de uma memória coletiva da sociedade. 


\subsection{Características das histórias em quadrinhos}

As histórias em quadrinhos são um meio de comunicação que pelas suas linguagens intrínsecas e pela sua complexidade artística, diferenciam-se de todos os demais meios de comunicação de massa. Ou seja, existem códigos específicos que são peculiares às linguagens das histórias em quadrinhos, que tornam esse meio de comunicação único, detentor de um conjunto de linguagens autônomas. Nos termos de Postema (2018):

Os quadrinhos, como uma forma de arte e de narrativa, são um sistema em que o número de elementos ou fragmentos díspares trabalham juntos para criar um todo completo. Os elementos dos quadrinhos são parcialmente pictóricos, parcialmente textuais e, por vezes, um híbrido dos dois. Esses elementos incluem as imagens dos quadrinhos ou cartoons; as molduras ou quadros que compõem as imagens, das quais o layout da página (inclusive o design do livro) é uma parte importante; assim como os recordatórios, os balões de fala e as próprias palavras, sejam as inseridas nos balões e recordatórios ou as integradas à imagem. (POSTEMA, 2018, p. 14-15).

Desse modo, por meio dessa forma narrativa peculiar própria dos quadrinhos, é possível construir sentido e também produzir informações de modo singular, fato esse que ocorre num contexto mais geral, ao longo da história da humanidade, no qual ocorreu o desenvolvimento de diferentes formas para a comunicação, como os desenhos e os sinais, processos esses influenciados fortemente pelas mais diversas situações sociais, uma vez que essas produzem (e reproduzem) as condições de existência desses grupos societários.

Tal fato faz com que as histórias em quadrinhos possuam um leque de recursos de linguagem que os tornam diferentes, por exemplo, do cinema, das emissoras de rádio e de televisão, da internet, dos jornais (eletrônicos e impressos em papel), da literatura e do teatro.

Os quadrinhos podem ser entendidos como uma narrativa sequencial por possuírem uma narração em quadros, no interior de um sistema narrativo, no 
qual ocorre a existência simultânea de dois códigos de linguagem: o pictórico (imagens) e o linguístico (as palavras escritas utilizadas nas narrações).

Além do uso dessas duas linguagens, as histórias em quadrinhos também trabalham com vários outros elementos de linguagens, tais como: os balões e os recordatórios, que transmitem as narrações de uma história em quadrinhos, além da possibilidade do uso das figuras de linguagem, como, por exemplo, as ironias, as metáforas visuais, as metonímias, as onomatopeias (sonogramas, úteis para reproduzir sons do universo acústico) e as parábolas visuais. Esse conjunto de linguagens torna complexa a leitura dos quadrinhos, pois:

Ao conectar esses fragmentos, preencher as lacunas envolve diversos e diferentes tipos de leitura, em que apenas uma é a leitura de palavras. A estrutura fragmentada dos quadrinhos envolve muitos códigos e signos variados em cada nível de significação (desenhos, layout, sequência, narrativa) e, consequentemente, exigem diferentes formas de decodificação em cada nível. (POSTEMA, 2018, p. 24).

Por exemplo, a linguagem escrita pode tanto apresentar ao leitor pensamento de um determinado personagem, como apresentar diálogos entre diferentes personagens de uma determinada trama, como também apresentar informações do percurso da história ao leitor.

Em específico, os balões podem possuir diferentes formatos, de acordo com o objetivo da narrativa. Por exemplo, no capítulo intitulado "Aspectos da linguagem, da narrativa e da estética das histórias em quadrinhos: convenções e rupturas", de Roberto Elísio dos Santos, presente no livro $A$ Linguagem dos quadrinhos: estudos de estética, linguística e semiótica, organizado por Vergueiro e Santos (2015), menciona a existência de nove formas diferentes de balões nas histórias em quadrinhos, sendo esses: cochicho (diálogo em voz baixa), splash (personagem nervoso), pensamento, eletrônico (sons que saem de equipamentos eletrônicos), glacial (desprezo de um personagem em relação a outro), tremido (expressão de medo), em off (personagem fora de cena), uníssono (mesma fala simultânea de diferentes personagens) e, por fim, 
o balão de fala intercalado. Lembra-se que cada um desses balões apresenta uma formatação diferente.

Além dos balões, os recordatórios têm uma função relevante nas histórias em quadrinhos, pois transmitem ao leitor uma narração (o que envolve tanto as noções de espaço como também a do tempo percorrido em uma história) ou expressam o pensamento de um determinado personagem ao leitor da narrativa.

Com relação às imagens, essas são usadas, por exemplo, para representar os ambientes, os cenários e os personagens das histórias e são obtidas pelos desenhos (o que envolve, por exemplo, um traço fino ou grosso) e pelas cores (por meio das mais diferentes tonalidades, ou até mesmo pela sua ausência). Desse modo, têm a capacidade de estabelecer diálogos entre si, com significados diferentes no interior de determinadas culturas e diversas condições sociais de existência do público leitor, podendo exibir diferentes expressões e significados. De acordo, novamente, com Postema (2018):

As imagens contêm diversos códigos, desde os que se relacionam com 0 próprio desenho, como as linhas, a perspectiva e as cores, até os que estão conectados ao mundo representado, como objetos materiais, linguagem corporal e códigos gestuais. [...] Os códigos simbólicos e os intertextuais acrescentam outra camada de significação, construindo sentidos conotativos sobre o significado denotativo puro e trazendo significados que não estão visíveis de forma explícita. $A$ isso, devemos acrescentar mais duas formas de significação que não podem ser representadas diretamente em imagens estáticas e isoladas, mas que estão em funcionamento, apesar disso. Essas formas são os códigos narrativo e temporal.

Normalmente, cada quadro individual apresenta um momento no tempo. A particularidade do momento retratado em quadros individuais codifica a narratividade: o momento que é mostrado não está finalizado. Isso torna implícito que se trata de um fragmento de um todo maior. Esse todo é a narrativa em progresso, não importando o quanto seja simples. Como resultado, um quadro cria, inevitavelmente, uma atração para as imagens que o circundam com o objetivo de completar 0 potencial narrativo de uma única imagem de quadrinhos. (POSTEMA, 2018, p. 41-42). 
Esses conjuntos de recursos de linguagens, apresentados ao público leitor de modo simultâneo, formam uma narrativa singular que tem a capacidade de apresentar um conteúdo muitas vezes criativo e inovador, ampliando as possibilidades de transmissão de informações, dos mais diferentes modos, expressos, por exemplo, pelas cores, luzes e sombras, movimentos, tempos, auxiliando, desse modo, no desenvolvimento da fantasia e da imaginação do público leitor. Essa combinação de recursos textuais e visuais também pode acelerar ou retardar a velocidade de leitura dos quadrinhos. Em função disso, é adequado notar que a narrativa de uma história em quadrinhos pode, potencialmente, solicitar várias formas de leitura por parte de seu público, sempre levando em consideração que a produção quadrinística trabalha com diferentes estruturas narrativas.

A partir desses códigos quadrinísticos, incluindo suas interações e também pela sua capacidade de formular críticas aos fatos e contextos sociais do mundo contemporâneo, os quadrinhos acabam por formatar um meio de comunicação privilegiado, pois pode expressar, de inúmeros modos, diferentes registros de visões particulares sobre os acontecimentos políticos e sociais. E, além do aspecto da linguagem ser singular quando comparado com os demais meios de comunicação, pode-se dizer, ainda, que as histórias em quadrinhos também possuem uma riqueza significativa em relação aos seus gêneros, podendo ser mencionados como exemplos: as adaptações de narrativas literárias, as aventuras, os educativos, as histórias de ficção científica, de guerra, as policiais, as aventuras dos super-heróis, as narrativas humorísticas e as histórias de terror.

Contudo, os quadrinhos também apresentam semelhanças em relação às diversas formas de expressão artística e outros meios de comunicação, pois todos esses compartilham diversas formas de linguagens. Nesse sentido, um dos exemplos que pode ser citado é a da caricatura política e social, que trabalha principalmente com a deformação de alguma(s) característica(s) do que está sendo retratado. Ou seja, a caricatura, ao representar um determinado personagem por meio do desenho, pode fazer uso do exagero ao enfatizar determinado(s) traço(s) de uma pessoa. Desse modo, as caricaturas podem ser utilizadas de diversas maneiras, tanto de forma crítica como irônica, 
ao reforçar gestos, hábitos ou vícios do personagem retratado, sendo comuns em situações que buscam transmitir ao leitor tanto o humor como a sátira política.

É possível afirmar que as relações entre as histórias em quadrinhos e as caricaturas são antigas, pois "os quadrinhos fazem grande uso da caricatura desde seus primórdios, até o ponto de haver criado em nossa cultura uma intensa identificação entre imagens caricaturescas e imagens de quadrinhos". (BARBIERI, 2017, p. 67). Com isso, por meio das caricaturas, é possível transmitir maior expressividade das figuras ao leitor, do mesmo modo que um quadrinho pode ser mais ou menos dramático, de acordo com os desenhos existentes em seu interior.

Existem também os quadrinhos expressionistas como Che, El Eternauta, Mort Cinder e Sherlock Time, sendo essas quatro publicações realizadas pelo argentino Héctor Germán Oesterheld (roteirista), em parceria com o uruguaio de nascimento, que mudou para a Argentina, com sua família, aos três anos, Alberto Breccia (desenhista). Outros autores que produzem quadrinhos expressionistas são os argentinos Carlos Sampayo (roteirista) e José Muñoz (desenhista).

Oesterheld, Alberto Breccia, Carlos Sampayo e José Muñoz são, no meio quadrinístico, profissionais que fizeram histórias em quadrinhos das mais respeitadas tanto na América Latina como na Europa. José Muñoz, por exemplo, teve a oportunidade, em sua carreira profissional, de conviver com Alberto Breccia (na condição de seu aluno) e Francisco Solano López (como seu assistente).

Barbieri (2017) menciona que as histórias em quadrinhos de Carlos Sampayo e José Muñoz têm ênfase em temáticas psicológicas e sociais, sendo histórias permeadas pela dramaticidade, fazendo uso, por exemplo, do desprezo social e da figura de linguagem da ironia, além de recursos artísticos parecidos com os usados nas caricaturas políticas e sociais. Além disso, Carlos Sampayo e José Muñoz fazem uso de uma quantidade significativa de signos em suas imagens, tornando a leitura de seus quadrinhos mais complexa e densa, apresentando ao leitor, por exemplo, um maior aprofundamento das 
personalidades dos protagonistas de seus quadrinhos e, por vezes, trabalhando, num mesmo quadrinho, mais de um plano de ação dos personagens de uma mesma história. Tal fato pode causar uma diminuição no tempo de leitura de suas histórias em quadrinhos, tendo em vista, também, a menor ou maior complexidade do fragmento de história apresentado ao leitor no interior deste enquadramento, o que envolve, por exemplo, as dimensões dos quadrinhos e a riqueza de detalhes existente no interior destes quadrinhos.

Outros exemplos de expressões artísticas que dialogam com as histórias em quadrinhos são as ilustrações e as pinturas, pois ambas realizam um trabalho intenso com a linguagem das imagens, ao retratar os ambientes, os objetos, as paisagens e as pessoas.

As ilustrações, as pinturas e os quadrinhos, também fazem uso da perspectiva, como forma de reproduzir a profundidade do espaço com a representação de figuras tridimensionais em um suporte plano (como uma folha de papel), que pode retratar tanto uma realidade "objetiva", como também uma "subjetiva", ou seja, ligada a uma representação interior de algum personagem ou grupo social, como, por exemplo: uma alucinação, um pensamento ou um sonho.

Desse modo, ao representar a profundidade do espaço, uma perspectiva é útil para aumentar o realismo de um desenho, para uma visualização mais ampla e satisfatória por parte do público leitor, por exemplo, ao enfocar uma determinada parte de uma imagem (objeto, paisagem ou pessoa), tendo em vista os objetivos do desenhista (e, de um modo geral, também do roteirista da história).

Todas essas representações artísticas, seja na forma de caricaturas, histórias em quadrinhos, ilustrações ou pinturas possuem uma importância e uma qualidade estética em si, que é apropriada pelo leitor das imagens de diferentes modos, o que envolve tanto a sua subjetividade como também uma possível influência cultural, econômica, política e social à qual esse leitor está submetido. E, além disso, esses produtos (ou mercadorias, no mundo capitalista) são produzidos (e comercializados) em determinados contextos culturais e econômicos que acabam influenciando essas produções. Com isso, 
a partir desse ponto de vista, as histórias em quadrinhos (como as caricaturas, as ilustrações, as pinturas e os demais bens culturais) podem ser passíveis de serem "desconstruídos" e contextualizados, por meio das análises e dos estudos científicos, com o objetivo de fornecerem conteúdos, nas mais diversas áreas do conhecimento, que são úteis para um maior entendimento acerca dos aspectos estruturais e também dos processos históricos e societários do mundo contemporâneo. 


\section{UMA REGIÃO SOB O AUTORITARISMO DO ESTADO: PERCALÇOS NA} AMÉRICA LATINA

Para Marx [1867] (2013), historicamente e também no mundo contemporâneo, sob a vigência do capitalismo, existem grupos societários que obtém privilégios em relação a outros grupos sociais, uma vez que os recursos são escassos e mal distribuídos.

Em específico, no capitalismo, para manter essa configuração econômica e social de dominação, perpetuando esse contexto favorável para alguns estratos sociais, as classes sociais privilegiadas, mais precisamente, os proprietários dos meios relevantes de produção, fazem uso das instituições jurídicas, militares, políticas e religiosas, disseminando, com isso, a sua ideologia de classe social, o que configura, portanto, uma relação de poder (e opressão) em diversas facetas da vida cotidiana, fazendo uso sistemático de práticas de manipulação no interior do imaginário social.

Essa dominação de classe social, em uma sociedade capitalista, quando levada ao extremo, pode dar origem ao fenômeno do totalitarismo. Tal fato guarda paralelos, no mundo atual, no âmbito das relações econômicas, com a lógica de valorização constante do capital e de crescente domínio desse mesmo capital sobre tudo ou, dito em outros termos, de um avanço do capitalismo que faz com que esse modo de produção esteja ocupando (ou invadindo), cada vez mais, praticamente todos os aspectos e espaços da vida cotidiana, formando, dessa maneira, uma verdadeira "roda infernal das mercadorias". Um exemplo de tal contexto é a concentração dos meios de comunicação (e, por exemplo, de modo subsequente, das formas de propaganda política) em poucas mãos, promovendo, desse modo, uma constante manipulação e um intenso controle ideológico.

Esse cenário, de uma configuração cultural, política e social organizada em uma busca sistemática do lucro, é expresso de diferentes modos, como, por exemplo, em sua face jurídica, por meio da garantia da propriedade privada pelo Estado (capitalista), que desse modo atua como uma instituição que protege essa forma de propriedade. Ou seja, não atua em favor do bem 
comum, nem ao menos para zelar pela satisfação das necessidades humanas mínimas de toda a população, mas sim a favor de uma determinada classe social.

Esse Estado pode atuar, inclusive, de formas autoritárias e repressivas, buscando defender os diversos processos de valorização do capital (na esfera econômica) e atuando a favor dos interesses de determinados grupos sociais que esse Estado representa (na esfera política), ou seja, nos dois casos, dos estratos sociais privilegiados.

Desse modo, o ser humano (e também a natureza) devem, necessariamente, submeter-se a uma determinada forma de domínio, com a constituição, na atualidade, de um poder total do capital, dando origem a um "mercado total", onde tudo é uma mercadoria e parcelas consideráveis de indivíduos deixam de serem vistos como humanos e passam a ser considerados como "consumidores" (ou marionetes do sistema), sendo modelados de acordo com considerações monetárias e sendo submetidos a uma forte imposição de padrões de comportamento (com a consequente perda de autonomia e também da capacidade de reflexão desses indivíduos), num contexto de crescente concentração do capital nas mãos dos proprietários dos meios relevantes de produção. Como lembra Pigozzi (2011), em artigo publicado nos anais das 1as. Jornadas Internacionais de Histórias em Quadrinhos, evento realizado na Escola de Comunicações e Artes da Universidade de São Paulo, em 2011:

Enfim, os indivíduos da sociedade civil se transformam em um conjunto de "cadáveres vivos", num contexto em que suas infinitas possibilidades de criação, imaginação e produção ficam inaproveitadas. Desse modo, os atores sociais se tornam apenas fantoches manipulados pelas normas sociais, que são elaboradas por apenas alguns indivíduos com interesses bem evidentes de dominação sobre a sociedade como um todo. (PIGOZZI, 2011, p. 4).

Essa forma de totalitarismo tem como características: uma ideologia oficial que não admite contestação (seja essa expressa pelo anarquismo, pelo 
comunismo ou, mais atualmente, pela ecologia) e, para tanto, faz uso sistemático de diversas formas de propaganda política; promoção de processos de atomização social que conduzem à individualização extrema, dificultando os debates políticos que acolhem diversos pontos de vista; além de executar um projeto de dominação sobre a sociedade civil como um todo, incluindo, desse modo, a assimilação (ou, até mesmo, a eliminação física) dos atores sociais críticos a este ideário político. O objetivo é o controle absoluto, ou seja, a dominação total dos indivíduos, por parte de alguns estratos sociais (ligados ao capital); para esse fim, pode ocorrer tanto a manipulação das consciências, individuais e coletivas, como também o uso de mecanismos que envolvam diferentes formas de punições e repressões.

Nesse último aspecto citado no parágrafo anterior, é incalculável o número de pessoas que sofreram (e sofrem) as consequências políticas pela defesa de suas ideias e sua luta pela igualdade social e justiça. Como exemplo, pode ser mencionado o assassinato, por milicianos fascistas, do deputado e escritor italiano Giacomo Matteotti, em 1924, que era uma das principais vozes que alertavam sobre o crescimento do fascismo na sociedade italiana. Como lembra Tannenbaum (1975), Matteotti era deputado do Partido Socialista e na época fazia intensa oposição ao fascismo e, também, à colaboração e aos acordos políticos com o governo de Benito Mussolini.

Dito de outro modo: o totalitarismo, potencialmente, pode levar ao extermínio de pessoas (e grupos societários) mais críticos e reflexivos em relação aos mecanismos de dominação existentes em uma sociedade dividida em classes sociais, como, por exemplo, o capitalismo. Para tanto, pode fazer uso dos campos de concentração, sendo esse um dos traços que caracterizou o totalitarismo nazista. É adequado ressaltar que os campos de trabalhos forçados não foram exclusividades do mundo capitalista, pois, por exemplo, também existiram na Rússia soviética sob o nome de gulags, onde estavam prisioneiros criminais e políticos, sob um sistema de repressão e punição. Applebaum (2004) menciona que existiam na Rússia, ao final de 1919, vinte e um campos de trabalhos forçados e, nesse mesmo país, ao final de 1920, o número desses campos era de cento e sete. 
Com isso, o totalitarismo é dependente da ideologia e da força bruta, objetiva o domínio total, fazendo uso, por vezes, dos campos de extermínio, expressando, desse modo, que as vidas dos membros de alguns estratos sociais são desnecessárias e dando origem a um consequente desprezo por esses seres humanos, considerados, portanto, como "supérfluos" ou "indesejáveis" para o sistema.

Desse modo, em sociedades totalitárias, ou com aspectos de autoritarismo extremo, ocorrem práticas de terror em massa contra os atores e grupos sociais que possuem uma visão de mundo divergente daquela dos donos do poder, num contexto de violenta repressão política, que, em alguma medida, reflete a luta de classes no capitalismo pelo acesso aos bens materiais e simbólicos e também pelo predomínio das narrativas e visões de mundo. Nos termos de Invernizzi e Gociol (2003):

No caso dos artistas em geral, e dos escritores em particular, a violência metódica do terror trabalhou simultaneamente sobre as pessoas e sobre a produção, contra homens e contra livros, desaparecendo a uns, censurando a outros. (INVERNIZZI; GOCIOL, 2003, p. 275, tradução nossa) ${ }^{3}$.

Tal cenário expõe um projeto político e social de domínio de alguns grupos sociais sobre outros, que busca sempre o domínio total, tanto em termos de ideários e narrativas, como também de práticas sociais, no interior de um contexto societário, práticas essas que buscam a internalização das regras do capital e, consequentemente, do mercado, pelos atores sociais. Com isso, configura-se um processo contínuo de moldagem das consciências e de imposição de uma ideologia, que afeta tanto os indivíduos (na esfera privada) como também os cidadãos (na esfera pública) e, além disso, dos grupos societários, expressos, por exemplo, nas formas de associações de trabalhadores ou na constituição de partidos políticos de oposição.

\footnotetext{
${ }^{3} \mathrm{Em}$ el caso de los artistas em general, y de los escritores en particular, la violencia metódica del terror trabajó simultaneamente sobre las personas y sobre la producción, contra hombres y contra libros, desapareciendo a unos, censurando a otros.
} 
Isso posto, esta tese busca uma aproximação entre um entendimento sobre as problemáticas políticas das sociedades totalitárias e algumas das ditaduras militares na América Latina, durante o século XX, com o intuito de compreender melhor, por meio dos meios de comunicação de massa e, em específico, pelas histórias em quadrinhos, a existência de características semelhantes entre o totalitarismo e o autoritarismo extremo dessas ditaduras, pelo uso, por exemplo, do terror absoluto, pois pertence a "própria natureza dos regimes totalitários exigir o poder ilimitado". (ARENDT, 1989, p. 507).

Essas ditaduras militares, na maioria das vezes, têm como contexto a Guerra Fria, num confronto estratégico, ideológico e político entre o mundo capitalista e os países que aderiram ao "socialismo real" (ou seja, as nações que tentaram colocar em prática as teses do socialismo científico). Todas as ditaduras militares latino-americanas defendiam a hegemonia do capitalismo, com duas exceções: no Equador, entre 1937 e 1938, sob o governo do general Alberto Enríquez Gallo e no Peru, entre 1968 e 1975, sob o governo do general Juan Francisco Velasco Alvarado.

No Equador, de acordo com Ayala Mora (2016), o general Alberto Enríquez Gallo manteve uma política nacionalista, obrigando as empresas estrangeiras a pagar impostos, além de controlar, de modo rigoroso, as importações. É importante ressaltar que em seu governo, vários ministros possuíam uma orientação socialista. López Romero (2016) lembra que durante esse período os indivíduos que possuíam um ideário de esquerda viveram num ambiente de liberdade, o que favoreceu a consolidação de suas organizações políticas.

Desse modo, é possível afirmar que Enríquez Gallo era receptivo às demandas das diferentes categorias profissionais pertencentes às classes que vivem do trabalho, incluindo tanto os trabalhadores rurais como também os urbanos.

Também digno de nota e que demonstra a politização dos mais diversos estratos sociais equatorianos foi a Gloriosa Revolución de Mayo, ocorrida em 1944, que é considerada, segundo Ayala Mora (2016), como sendo, até os dias 
atuais, a mobilização democrática e popular mais importante da história do Equador.

A Gloriosa Revolución de Mayo teve início da cidade de Guaiaquil e chegou a todo o território equatoriano. Com isso, o então presidente Carlos Alberto Arroyo del Río foi deposto e, além disso, também evitou que ele fosse substituído na presidência pelo seu candidato preferido, Miguel Ángel Albornoz.

Rodas Chaves (2016) e Vega Ugalde (2016) mencionam como principais características da Gloriosa Revolución de Mayo o fato de ter sido uma mobilização popular massiva, que ocorreu nos mais diversos espaços territoriais do Equador, com uma presença marcante do ideário e da ação política socialista.

No Peru, durante o período em que foi governado pelo general Juan Francisco Velasco Alvarado, num primeiro momento, ocorreu uma ruptura com os Estados Unidos e, posteriormente, efetivou-se um alinhamento ao "socialismo real", expresso, principalmente, pela União Soviética.

Seu governo realizou a reforma agrária, educacional, industrial, além da nacionalização dos bancos, dos meios de comunicação, da pesca, além dos recursos naturais, como lembram Coggiola (2001) e Rénique (2009). Tal contexto social favoreceu amplamente a mobilização das camadas populares peruanas.

É adequado lembrar o histórico de politização das classes que vivem do trabalho no Peru, com a fundação já em 1924 da APRA (Aliança Popular Revolucionária Americana), um partido social-democrata, o qual, de acordo com Rénique (2009), sofreu uma divisão interna em 1960, dando origem ao Movimiento de Izquierda Revolucionaria (MIR), fortemente influenciado pelo contexto histórico da Revolução Cubana de 1959. Esse último grupo que optou por uma resistência armada aos diferentes governos peruanos, praticamente deixou de existir, como grupo armado, em 1966, com a morte, nessa resistência armada, de Guillermo Lobatón Milla que, naquele momento, liderava uma das frentes desta organização. 
Também na década de 1920 ocorre a fundação do Partido Comunista Peruano e, além disso, Drinot (2017) ressalta a fundação, na década de 1960, do Ejercito de Liberación Nacional (ELN) neste mesmo país.

De acordo com Milton (2017), entre o ano de 1980 e a metade da década de 1990, ocorre um conflito armado entre o grupo peruano Sendero Luminoso e o Estado, que resultou em mais de 69.000 mortos e desaparecidos, de acordo com o relatório final da Comisión de la Verdade y Reconciliación, publicado em 2003.

No Paraguai, tendo como fonte o jornal $A B C$ Color, em específico na seção "Especiales - $25^{\circ}$ aniversario del Golpe de Estado"4, a ditadura militar teve início em 1954 e término em 1989, durando quase trinta e cinco anos, sendo a mais longa da América Latina. Durante este período, o presidente foi Alfredo Stroessner Matiauda, que era, desde 1951, o comandante-chefe das Forças Armadas paraguaias.

Stroessner foi eleito presidente numa votação onde apenas filiados do Partido Colorado votaram para o cargo de presidente do Paraguai. Já em 1955, Stroessner começou um processo de institucionalização da ditadura, por meio de mudanças na legislação e, no ano seguinte, no país, aconteceram seguidas manifestações nas ruas desfavoráveis ao presidente, promovidas pela sociedade civil. Sua ditadura foi marcada pela repressão às pessoas críticas ao seu governo ditatorial, pela repressão à imprensa e também por detenções arbitrárias.

No Brasil, em seu período republicano, os militares sempre foram influentes politicamente na vida nacional. Como lembra Cavalcante Neto (2013) e, também, o filme Imagens do Estado Novo (2018), os militares apoiaram tanto o período de governo que ficou conhecido por Estado Novo (1937-1945), chefiado por Getúlio Vargas, como também participaram ativamente da deposição desse presidente, em 1945. Além disso, os militares pressionaram politicamente Vargas, durante o seu segundo mandato, até

4 Disponível em: <http://www.abc.com.py/especiales/25-aniversario-del-golpe-de-1989/>. Acesso em: 17 nov. 2018. 
1954. Posteriormente, realizaram um golpe de Estado, entre os dias 31 de março e 1ํ de abril de 1964, com a deposição do presidente João Goulart, com o apoio de outros estratos sociais, como os proprietários dos meios relevantes de produção, da Igreja Católica e de vários veículos de comunicação.

Existiram várias motivações para a execução desse golpe militar. Algumas dessas foram propostas do governo Goulart, como, por exemplo, a realização das reformas agrária e urbana; além da luta contra a possível existência de comunistas na sociedade civil, tendo como alvo, por exemplo, membros do Partido Comunista Brasileiro (PCB). Para tanto, os militares fizeram uso de atos institucionais, num visível desapreço pela Constituição então vigente. Essa ditadura militar existiu até o ano de 1985.

Esse histórico tem inúmeras consequências até os dias atuais, o que envolve, por exemplo, o autoritarismo, a corrupção, a falta de uma maior problematização acerca da cultura política para amplas parcelas da sociedade, a injusta distribuição de renda, a militarização da segurança pública, a péssima educação pública no Ensino Fundamental e Médio, além da situação precária dos mais diversos serviços públicos.

$\mathrm{Na}$ Bolívia, os dois períodos de ditadura militar mais repressoras contra a sociedade civil foram: a do general René Barrientos Ortuño (1964-1969), que assumiu o poder por meio de um golpe de Estado. Seu período de governo foi marcado por assassinatos políticos, pelas prisões arbitrárias, pela repressão e tortura contra membros da sociedade civil.

Posteriormente, Hugo Banzer Suárez (1971-1978), promoveu, no período de sua presidência, repressão ao estudantes e trabalhadores rurais e urbanos, com um governo marcado fortemente pela ideologia anticomunista, como lembra Coggiola (2001).

Por sua vez, o Chile, país de forte tradição democrática no continente americano, foi governado entre 1964 e 1970 pelo advogado e sociólogo Eduardo Frei Montalva, que possuía um ideário e uma prática política socialdemocrata, cujo lema era "revolución em libertad". Ao final do seu mandato, foram realizadas eleições, sendo eleito para presidente o médico Salvador 
Allende Gossens, com a proposta de uma via democrática em direção ao socialismo, numa coalizão chamada Unidade Popular.

Essa frente incluía um grupo significativo de partidos políticos, entre eles o Partido Socialista Chileno (PS, sendo Allende um dos fundadores dessa agremiação partidária, em 1933) e o Partido Comunista de Chile (PC, fundado em 1922), com o apoio crítico do Movimiento de Izquierda Revolucionaria (MIR), organização essa que foi fundada em 1965, na Universidade de Concepción, de acordo com Collier e Sater (1998). Uma contextualização e um histórico mais detalhado do MIR, é feito pelo pesquisador Salinas Cañas (2013), doutor em Estudos Latino-Americanos, pela Universidade do Chile, no livro El Tres letras. Historia y contexto del Movimiento de Izquierda Revolucionaria (MIR).

De acordo com Winn (2010), Allende realizou quatro reformas estruturais no período de seu governo: nacionalização das minas de cobre que pertenciam aos Estados Unidos; nacionalização dos bancos privados; a reforma agrária (as fazendas que possuíam alta tecnologia passaram para as mãos do Estado chileno, porém a maior parte das propriedades rurais foi transferida para os camponeses, por meio de cooperativas - ou seja, não na forma de propriedade privada); além de uma socialização das maiores empresas chilenas de produção e distribuição, tanto na forma de apropriação pelo Estado como também na forma de participação privada e pública numa mesma unidade produtiva, com a participação dos funcionários e representantes do Estado na administração, em todas essas empresas socializadas.

Além disso, no governo de Allende também ocorreram a democratização do sistema escolar, uma intensa mobilização popular nas áreas rurais e urbanas, além de uma maior politização das massas. Contudo, em 11 de setembro de 1973, o governo civil foi deposto pelo militar Augusto José Ramón Pinochet (que chegou a ocupar o posto de Comandante em Chefe do Exército Chileno durante o governo de Allende) e, durante o golpe militar, chegou a bombardear o palácio presidencial.

Ao longo dos anos da ditadura militar de Pinochet ocorreram assassinatos políticos em larga escala, além da existência, em território chileno, dos campos 
de concentração, um dos traços característicos das ditaduras totalitárias, nos quais ficavam os ativistas políticos de esquerda e os apoiadores de Allende que, nesse momento histórico, não representavam ameaça às autoridades militares. Esses campos de concentração de prisioneiros políticos ficavam, de acordo com Winn (2010), na Antártida e nos desertos chilenos. Contudo, Collier e Sater (1998), mencionam a abertura de campos de concentração de modo generalizado no território chileno.

Entre as dezenas de milhares de mortos estão, de acordo Doucey (2009), Víctor Jara, artista musical que também atuava no teatro. Defensor dos direitos humanos, praticava a denúncia acerca da repressão policial e atuava em favor da reforma agrária. Outra vítima dessa ditadura foi, de acordo com Collier e Sater (1998), Orlando Letelier del Solar, ex-embaixador do presidente Allende. O fim dessa ditadura militar data de 1990, de acordo com Coggiola (2001).

No Uruguai, o presidente (civil) Juan María Bordaberry, fez uma aliança com os militares, em 1973, para a formação de um governo autoritário, o qual durou até o ano de 1984 (neste momento, sem Bordaberry). Durante esse período, ocorreu a implantação de um sistema de vigilância dos membros da sociedade civil uruguaia, aliado a um desmantelamento de algumas organizações sociais e sindicais. Além disso, ocorreram seguidos casos de detenção de militantes políticos, exílios e a prática sistemática da tortura. Como relata Galeano (2001):

No Uruguai existem de quatro a cinco mil presos políticos. Não é pouco. No começo foram os guerrilheiros. Depois, os militantes dos partidos de esquerda. Depois, os sindicalistas. Depois, os intelectuais. Depois, políticos tradicionais. Depois, qualquer um. A máquina não pára, exige combustível, enlouquece, devora o inventor: os partidos de direita outorgaram poderes especiais e recursos extraordinários às forças armadas para livrar-se dos tupamaros e em pouco tempo os militares ficaram com o poder e liquidaram os partidos. Entre 1973 e 1974, vinte mil pessoas passaram pelas prisões e pelos quartéis; a tortura se converteu num sistema interrogatório habitual. Nas câmaras de tortura, muitos homens já perderam a vida. [...]"

Se isso tudo não é fascismo, reconheçamos que se parece muito: o mesmo instrumental fascista de ameaça e repressão é posto em prática. $\mathrm{Na}$ verdade, ele resulta útil, mas não para conquistar o mundo; serve para massacrar as forças internas de 
transformação, para decapitar a classe operária e aniquilar a inteligência. (GALEANO, 2001, p.124-125).

Já na Argentina, menciona-se, como exemplo de disputa entre classes sociais e suas diferentes visões de mundo, o importante fato histórico do cordobazo, ocorrido no final do mês de maio de 1969, que foi o levante de estudantes e operários, o qual teve início da cidade de Córdoba, espalhandose, em seguida para outras cidades, como Corrientes, Rosário e Tucumán. Essa rebelião, de carácter nitidamente popular, realizava protestos em relação ao governo militar de Onganía.

De acordo com Terán (2010), foi nesse contexto de tensão política e aumento do número de pessoas que estavam aderindo ao pensamento marxista que, a partir de 1970, tem início na Argentina o uso crescente de assassinatos políticos, incluindo o de militantes políticos socialistas e dirigentes sindicais. Tal fato pode ser evidenciado pelo fato de que

a partir de 1970, com o pano de fundo de expressivo conflito social, organizações político-militares provenientes da esquerda marxista e peronista começaram a operar de maneira crescente após a proclamação do objetivo de libertação nacional e social. Este modo de operação incluiu [...] assassinatos políticos [...]. Muitas dessas ações foram justificadas pelo fato de que estavam inscritas em uma história de violações e injustiças anteriores que tinham sido vítimas as classes populares e o movimento peronista. (TERÁN, 2010, p. 290, tradução nossa) ${ }^{5}$.

Também aumentava, num setor da intelectualidade, um consenso sobre a necessidade de uma saída revolucionária para a Argentina, tendo em vista o cenário atual dessa nação, discutindo questões relacionadas a forma como

\footnotetext{
${ }^{5}$ Desde 1970, sobre aquel trasfondo de alta conflictividad social, organizaciones político-militares provenientes de la izquierda marxista y peronista comenzaron a operar de manera cresciente trasel proclamado objetivo de liberación nacional y social. Ese modo operativo incluyó [...] asesinatos políticos [...]. Muchas de estas acciones fueron justificadas puesto que se las inscribía en una historia de violaciones e injusticias anteriores que había tenido como víctima a las clases populares y el movimento peronista.
} 
isso poderia ocorrer e as relações entre a intelectualidade, as relações políticas e a revolução.

Nesse contexto, de acordo com Coggiola (2001) e Montero (2013), em 1973 começava a entrar em ação na Argentina a Aliança Anticomunista Argentina (AAA) - Triple A, que era, na verdade, um "esquadrão da morte", promovendo uma sequência de atentados e assassinatos políticos contra os membros da sociedade civil que possuíam uma mentalidade comunista (e, por vezes, até mesmo lideranças políticas democráticas que defendiam 0 capitalismo) e que lutavam em favor da conformação de uma nova sociedade, mais preocupada com a solidariedade e menos preocupada com o capital. Montero (2013) apresenta os seguintes dados sobre a atuação da Triple A, no período compreendido entre 1973 e 1976: no mínimo 1.500 assassinatos, 600 desaparecidos, além de centenas de atentados (em diversos locais, como instituições partidárias, residências e vias públicas).

Gillespie (1998) afirma que Triple A possuía proteção do Poder Público, dando a impressão de ter imunidade em relação à legislação vigente, num cenário de intensa violência política. Também menciona o fato de que em seguidas ocasiões, integrantes dos Montoneros - grupo político-militar de esquerda -, que eram feridos, passavam por atendimentos médicos nas ruas e, posteriormente, assassinados nas ambulâncias (que pertenciam ao sistema público de saúde), ou mesmo levados para locais onde eram torturados, antes de serem mortos.

Desse modo, é possível afirmar que na Argentina a repressão aos grupos de militantes com ideário político de esquerda começou antes de um período de ditadura militar, pois em 1973 a Argentina foi governada por dois civis: Héctor José Cámpora e Raúl Alberto Lastiri, até a volta de Juan Domingo Perón ao poder, neste mesmo ano.

E, posteriormente, com a morte de Perón, em julho de 1974, e com a ascensão de sua esposa Maria Estela Martínez de Perón, conhecida como "Isabel" ou "Isabelita" Perón, à presidência da República, a direita e a ultradireita peronista ganham maior importância no governo argentino. 
Neste governo, de Maria Estela Martínez de Perón, ocorreram seguidas greves dos trabalhadores argentinos, com conflitos constantes entre membros das classes que vivem do trabalho e o Exército, além de seguidos assassinatos políticos.

Neste contexto ocorre, em 24 de março de 1976, o golpe militar que leva o general Jorge Rafael Videla à presidência. A junta militar que tomou o poder tinha, além de Videla, responsável pelo Exército, o almirante Emilio Eduardo Massera, responsável pela Marinha, e o brigadeiro Orlando Ramón Agosti, responsável pela Força Aérea.

Segundo Gillespie (1998), com o golpe militar, foram dissolvidas as legislaturas das províncias e também o Congresso argentino, com a consequente deposição dos governadores e dos legisladores, além dos juízes. Restrições atingiram o movimento estudantil e os partidos políticos. Além disso, os sindicatos de maior relevância sofreram intervenções do Estado e alguns sindicalistas foram presos, o que também ocorreu com lideranças políticas.

Ainda de acordo com Gillespie (1998), também passaram a existir "conselhos de guerra militares", que adotavam sentenças de morte para os réus, ou seja, os membros da sociedade civil que eram acusados de subversão.

Com isso, a partir desse momento, a violência política aumentou ainda mais, em função da prática do que ficou conhecido historicamente como "terrorismo de Estado": uma luta contra o operariado e demais setores progressistas da sociedade civil, que possuía como características o fato de ser planejado e ocorrer de modo sistemático, abrangendo práticas como 0 sequestro, a tortura, e o "desaparecimento" de militantes socialistas.

De acordo com os pesquisadores Invernizzi e Gociol (2003), a ditadura militar que teve o general Videla como presidente, possuía um projeto nacional, que era apoiado pelos governos das províncias argentinas, com objetivos bem evidentes: 
[...] não há dúvidas ao fato de que o terrorismo de Estado foi um plano sistemático [...] o desaparecimento do corpo de pessoas corresponde ao projeto de desaparecimento sistemático de símbolos, discursos, imagens e tradições. Dito de outro modo: que a estratégia para a cultura foi funcional e necessária para o cumprimento integral do terrorismo de Estado como estratégia de controle e disciplinamento da sociedade argentina.

Por um lado, estavam os campos de concentração, as prisões e os grupos de tarefas. De outro, uma complexa infraestrutura de controle cultural e educativo, a qual envolvia equipes de censura, análises de inteligência, advogados, intelectuais e acadêmicos, planos editoriais, decretos, ordens, pressupostos, escritórios... Duas infraestruturas complementares e inseparáveis desde sua própria concepção. Duas caras da mesma moeda. (INVERNIZZI; GOCIOL, 2003, p. 23, tradução nossa) ${ }^{6}$.

Neste cenário, era comum a seguinte prática: os agentes desta ditadura militar retiravam a vítima de sua residência, levavam esta pessoa até um centro de detenção, onde, em meio aos procedimentos de tortura, buscam interrogar o investigado.

Posteriormente, esse ser humano "desaparecia”, numa situação em que nem seus próprios familiares tinham acesso ao seu destino final, como, por exemplo, o local de sua morte.

Por vezes, o acusado era morto única e exclusivamente por "crimes" de associação ou mesmo de opinião, não tendo relação alguma com 0 pertencimento a grupos armados de resistência da sociedade civil à ditadura militar.

Com isso, apenas durante a ditadura do general Videla, a qual teve início em 24 de março de 1976, ocorreram 30.000 mortos, num cenário de aliança entre o empresariado e as Forças Armadas contra membros da sociedade civil

\footnotetext{
${ }^{6}[\ldots]$ no hay dudas respecto de que el terrorismo de Estado fue um plan sistemático [...] a la desaparición del cuerpo de las personas se corresponde el proyecto de desaparición sistemático de símbolos, discursos, imágenes y tradiciones. Dicho de outro modo: que la estratégia hacia la cultura fue funcional y necesaria para el cumplimiento integral del terrorismo de Estado como estratégia de control y disciplinamento de la sociedad argentina.

De un lado estaban los campos de concentración, las prisiones y los grupos de tareas. Del otro, una compleja infraestructura de control cultural y educativo, la cual implicaba equipos de censura, análisis de inteligência, abogados, intelectuales y académicos, planes editoriales, decretos, dictámenes, pressupuestos, oficinas. Dos infraestructuras complementarias e inseparables desde su misma concepción. Dos caras de la misma moneda.
} 
de mentalidade socialista. De acordo com Coggiola (2001), nesse período ditatorial existiram trezentos e sessenta e dois campos de concentração (e extermínio) no território argentino, o que, do mesmo modo que no Chile, aproxima esse período histórico que ficou conhecido como terrorismo de Estado do totalitarismo. O fim da ditadura do general Videla ocorreu em 1981.

Após a saída do general Videla da presidência, outros militares continuaram a governar a Argentina: Roberto Eduardo Viola, Horácio Tomás Liendo e Carlos Alberto Lacoste (ambos em 1981); posteriormente Leopoldo Galtieri (entre 1981 e 1982); depois Alfredo Oscar Saint-Jean (em 1982) e, por fim, Reinaldo Bignone (1982-1983).

Retomando o jornal paraguaio $A B C$ Color, em específico na seção "Especiales $-25^{\circ}$ aniversario del Golpe de Estado"7, existiu, entre alguns dos países citados neste capítulo, desta tese, no caso: Argentina, Bolívia, Brasil, Chile, Paraguai e Uruguai, uma aliança político-militar, de caráter fortemente anticomunista, chamada Operação Condor, a qual promovia, de algum modo, uma organização desses sistemas repressivos. Eram características desses sistemas, que atuavam em conjunto, o uso sistemático de torturas, assassinatos e troca de prisioneiros entre essas nações. De acordo com esse jornal, o nascimento da Operação Condor ocorreu na data de 25 de novembro de 1976, no Chile, durante a ditadura de Pinochet.

Na América Central, em 1959, ocorre a Revolução Cubana, que pôs fim à ditadura de Fulgêncio Batista. Tal fato ocorreu com intensa participação popular e é um acontecimento importante para um maior entendimento acerca dos conflitos entre o capitalismo e o "socialismo real" durante o século XX, pois Cuba foi o primeiro país a sair da área de influência dos Estados Unidos nas Américas. O novo governo realizou a reforma agrária, a nacionalização das empresas e se aproximou da União Soviética, tornando-se o primeiro país do continente americano a adotar o "socialismo real" como norte para o seu desenvolvimento.

\footnotetext{
7 Disponível em: <http://www.abc.com.py/especiales/25-aniversario-del-golpe-de-1989/>.
} Acesso em: 17 nov. 2018. 
Valladares e Berbel (1994) lembram que essa adesão ao socialismo somente ocorreu dois anos após a tomada do poder pelo grupo revolucionário, liderados por Fidel Castro e Ernesto "Che" Guevara, esse último morto em 1967, na Bolívia, fato trabalhado pelo quadrinista Héctor Germán Oesterheld e pelos desenhistas Alberto Breccia e Enrique Breccia (filho de Alberto Breccia), na graphic novel Che.

Com isso, foi adotada uma política econômica que acabou com o desemprego e, além disso, ocorreu uma intervenção estatal com o objetivo de baixar os valores dos aluguéis. A assistência médica, a educação, e também o acesso à justiça se tornaram gratuitos para a população cubana.

Buscando um maior entendimento acerca dos conflitos entre o mundo capitalista e do "socialismo real", nesse momento histórico, é necessário lembrar a crise dos mísseis, ocorrida em 1962, quando a União Soviética instalou mísseis em território cubano. Esses mísseis tinham capacidade de alcance para atingir Washington, a capital dos Estados Unidos, em cerca de quinze minutos. Após sérias ameaças de retaliação dos Estados Unidos, esses equipamentos bélicos foram retirados de Cuba.

Nos últimos anos, esse modelo "socialista" foi flexibilizado com a possibilidade legal de existência de práticas comerciais mais próximas do capitalismo, principalmente depois do fim da União Soviética.

Na Nicarágua, de acordo com Zimmermann (2006), o regime do militar Anastasio Somoza fez uso intenso da repressão política contra os membros da sociedade civil, incluindo, entre os anos de 1976 e 1977, a utilização de incêndios (em plantações e residências), bombas, e, até mesmo, de napalm em assentamentos.

E, como na Argentina e no Chile, na Nicarágua também existiram casos de torturas e uso dos campos de concentração, o que guarda relações com as práticas típicas de regimes totalitários.

Em função de uma indignação moral da sociedade civil nicaraguense em relação ao uso sistemático da violência por parte desse regime, ocorreu um fortalecimento do grupo denominado como Frente Sandinista de Libertação 
Nacional (FSLN), de orientação marxista, que lutava pelo fim desse governo ditatorial.

A partir de então, a FSLN conseguiu aumentar o número de seus militantes e também um acréscimo de contatos políticos. Zimmermann (2006) também lembra a importância da imprensa nesse momento, como meio de esclarecimento da sociedade civil, por meio do jornal La Prensa, que teve, inclusive, o seu editor, Pedro Joaquín Chamorro, assassinado quando se dirigia ao trabalho, na data de 10 de janeiro de 1978.

Após essa ocorrência, eclodiram diversas demonstrações de protesto em relação ao governo de Anastasio Somoza, o que incluiu a convocação de uma greve nacional que tinha como objetivo a renúncia de Somoza, num cenário de ataques à Guarda Nacional, formação de comitês de direitos civis, lutas urbanas (principalmente em bairros pobres de moradores operários), ocupações de terras, ocupação de edifícios, além da tomada de uma cidade (Estelí, por dez dias, em abril de 1979). No final de junho de 1979, a FSLN controlava mais de vinte cidades.

É importante ressaltar que a repressão política de Anastasio Somoza sobre a sociedade civil continuou nesse período, com a existência na Nicarágua, como em El Salvador e na Guatemala, de grupos paramilitares de direita, ou "esquadrões da morte", com forte retórica anticomunista. Nesse ano, 1979, um relatório da Cruz Vermelha calculava em torno de 50.000 civis mortos pelas forças do Estado, durante essa guerra civil, que durou cerca de dezoito meses.

Ainda tendo como referência o livro de Zimmermann (2006), é lembrado que, em função de vários fatores, como: as ações repressivas do governo em relação às classes que vivem do trabalho; um esforço de mobilização política por parte da FSLN; uma importante greve de estudantes que fechou parcela significativa das escolas e também das universidades daquele país; além das relevantes ações da sociedade civil, por vezes realizadas de modo espontâneo, tiveram como consequência um progressivo enfraquecimento da gestão de Anastasio Somoza. 
De acordo com o Nepomuceno (1985) e Zimmermann (2006), o governo de Anastasio Somoza (que, na época, era uma das pessoas mais ricas da América Latina e também o maior proprietário de terras da Nicarágua) foi derrubado em julho de 1979, com a vitória da FSLN. Essa vitória contou com amplo apoio da sociedade civil. Zimmermann (2006) ressalta ainda que, na data de 20 de julho de 1979, cerca de duzentas e cinquenta mil pessoas se reuniram na Praça da Revolução para comemorar a vitória e saudar o novo governo. Muitos desses manifestantes portavam bandeiras vermelhas e pretas.

Essa guerra civil, ao final, deixou dezenas de milhares de vítimas, incluindo feridos e mortos (com um significativo número de feridos ainda precisando de assistência médica permanente em 1980). Um país próximo, Cuba, logo após ao final da guerra, começou a auxiliar a Nicarágua, com o envio diário de alimentos como leite e medicamentos, além de profissionais da área da saúde (enfermeiros e médicos).

O governo sandinista, enquanto esteve no poder, auxiliou na formação de cooperativas, confiscou toda a fortuna de Anastasio Somoza, criou impostos que incidiam sobre produtos de luxo importados, diminuiu os valores dos aluguéis pagos pelos trabalhadores, dissolveu a Guarda Nacional, nacionalizou todos os bancos do país, além de realizar a reforma agrária e criar novas fazendas estatais. Na esfera das comunicações, um jornal de ampla circulação, dois canais de televisão, além de várias estações de rádio, que eram propriedade de Anastasio Somoza, transformaram-se em porta-vozes do discurso sandinista.

Além disso, no âmbito da educação, o governo sandinista transformou casas e escritórios que pertenciam à Anastasio Somoza em centro culturais, creches e escolas, além de promover uma campanha eficiente de alfabetização. Essa campanha usou de modo massivo as histórias em quadrinhos, como será visto no capítulo quatro desta tese.

Outro país da América Central, a Guatemala conviveu com conflitos armados internos entre as décadas de 1960 e 1990, tanto nas áreas rurais como urbanas, entre o Estado e os militantes de esquerda. Esses grupos 
armados de esquerda não atingiram o seu objetivo principal, a tomada do poder.

De acordo com Coggiola (2001), essa nação, somente ao longo da década de 1980, possuía cerca de 100.000 mortos e 50.000 desaparecidos, em decorrência destes conflitos políticos.

Segundo Bastos (2006), os acordos de paz foram assinados entre as partes envolvidas nesse conflito armado em 1996. Porém, Bastos (2006) também afirma que, após essa data, um dos principais problemas da Guatemala continua sendo a formação de um Estado militarizado (ou seja, uma forte presença dos militares no Poder Público). 


\section{PANORAMA DOS QUADRINHOS DE CRÍTICA SOCIAL E POLÍTICA NA} AMÉRICA LATINA

Tendo em vista a problemática do autoritarismo discutida no capítulo anterior, é necessário lembrar que tal fato teve impacto nos meios de comunicação de massa, o que inclui as histórias em quadrinhos.

Isso posto, este capítulo trata dos quadrinhos em alguns dos vários países latino-americanos, referindo-se a autores e produções que tenham conteúdo de crítica social e política, o que inclui as adaptações literárias. Portanto, o objetivo deste capítulo não é fornecer a um possível leitor um histórico da produção quadrinística latino-americana, mas apresentar alguns quadrinhos que possuem, em alguma medida, identidade temática com a produção oesterheldiana.

Na América Latina, as histórias em quadrinhos têm sido publicadas, desde a segunda metade do século XIX, para os mais variados fins, como a alfabetização, o entretenimento e a cultura política. Neste capítulo estão expostas algumas contribuições das histórias em quadrinhos em relação a este último aspecto.

Na América do Sul, em específico na Argentina, Silva Junior (2017) aponta as histórias ilustradas sequenciadas (sem legenda nos quadrinhos ou diálogos com uso dos balões) como precursoras dos quadrinhos já na segunda metade do século XIX, sendo, em sua maioria, publicações que apresentavam ao leitor críticas políticas e sociais (de um modo geral com dois quadrinhos), além das caricaturas de políticos.

Sobre as histórias em quadrinhos propriamente ditas, Gociol e Rosemberg (2003) mencionam que, até o ano de 1945, a característica distintiva dessa produção era a quantidade de publicações (e nem sempre sua qualidade). Ainda assim, as décadas de 1940 e 1950 são consideradas, no histórico da produção de quadrinhos argentinos, como sendo la época de oro.

Tendo em vista o panorama cultural argentino da época, deve-se considerar que os anos 1940 e 1950 marcam justamente o período anterior à 
presença massiva da televisão, como meio de comunicação, no território argentino. É nesse período histórico que aparece a figura do roteirista como um profissional atuante no circuito de produção de quadrinhos (anteriormente, os desenhos e a narrativa da história eram feitos pelo mesmo profissional) e é também durante esse intervalo histórico que o público leitor argentino passou a exigir, de modo mais firme, publicações de melhor nível, com roteiros adultos, estruturados de modo adequado e com desenhos de qualidade.

Nesse contexto, ainda de acordo com Gociol e Rosemberg (2003), a revista Misterix, lançada em 1948 e pertencente à editora Abril, que chegou a ter uma tiragem de duzentos e cinquenta mil exemplares, propôs a um conjunto de desenhistas e roteiristas italianos, no início dos anos 1950, que viessem trabalhar na Argentina, recebendo bons salários. Com isso, vieram para a Argentina: Alberto Ongaro, Hugo Pratt, Guillermo Letteri, Ivo Pavoni e Mario Faustinelli.

Esses profissionais mencionados no parágrafo acima tiveram importante papel na consolidação da produção de histórias em quadrinhos em território argentino, pois a indústria quadrinística nesse país passou a ter uma maior autonomia em relação aos modelos estrangeiros que influenciavam os quadrinhos argentinos, como o estadunidense, de acordo com CataláCarrasco, Drinot e Scorer (2017) e também, em menor medida, o mexicano, de acordo com Gociol e Rosemberg (2003). É adequado também ressaltar o trabalho com quadrinhos, nesta época, do ilustrador argentino José Luis Salinas, principalmente entre as décadas de 1930 e 1970, em especial nos quadrinhos dos gêneros das aventuras e das adaptações literárias, como lembra Silva Junior (2017).

É necessário lembrar o contexto da época, no qual esses profissionais que chegaram da Itália para trabalhar com histórias em quadrinhos na Argentina, haviam vivenciado, na Europa, os horrores da recém terminada Segunda Guerra Mundial, o que marcou profundamente a visão de mundo deste grupo. Inclusive, de acordo com Montero (2013), dois deles, Alberto Ongaro e Mario Faustinelli, foram militantes que lutavam pelo fim do fascismo na Itália, tendo sido, inclusive, presos por tal fato durante esta guerra. 
Nesse cenário, mais precisamente em março de 1957, tiveram início duas novas publicações: as revistas de quadrinhos Hora Cero e Frontera, ambas pertencentes à editora Frontera, fundada por Héctor Germán Oesterheld, que publicaram várias das principais histórias em quadrinhos argentinas (e latinoamericanas), como El Eternauta (com desenhos de Solano López), Sherlock Time (com desenhos de Alberto Breccia) e Ernie Pike e Ticonderoga (com desenhos de Hugo Pratt), entre outras. A produção quadrinística do roteirista Oesterheld ocorria, principalmente, em parceria com esses três desenhistas.

Em linhas gerais, a editora Frontera permitia aos seus desenhistas uma maior liberdade de criação, quando comparado a outras editoras, o que era um dos fatores de atração desses profissionais para essa casa publicadora.

Posteriormente, em setembro de 1957, apareceu a revista satírica Tía Vicenta (de humorismo político), do caricaturista Landrú (Juan Carlos Colombres), que faleceu em 2017. De acordo com Fossati (1997), a revista Tía Vicenta tinha, entre os principais colaboradores, autores como Copi (Raúl Damonte Taborda), Kalondi (Héctor Compaired), Oski (Oscar Conti) e Quino (Joaquín Salvador Lavado).

No início da década de 1960, entre os anos de 1962 e 1964, o roteirista Oesterheld e o desenhista Alberto Breccia publicaram por meio das revistas Misterix e Supermisterix uma das principais histórias em quadrinhos da produção quadrinística latino-americana: "Mort Cinder".

Poucos anos depois, apareceu uma das mais conhecidas personagens do meio quadrinístico latino-americano (e também europeu): a Mafalda, de Quino. A personagem Mafalda possui um perfil reflexivo e contestador em relação ao mundo cotidiano em que vive, tratando das mais diversas temáticas, como: a ecologia, a política e as relações familiares. As tiras da Mafalda foram publicadas em jornais e revistas e, de acordo com Gociol e Rosemberg (2003), Catalá-Carrasco, Drinot e Scorer (2017) e Silva Junior (2017), essas publicações ocorreram entre 1964 e 1973.

No Brasil, foram publicadas as histórias em quadrinhos Toda Mafalda, no ano de 2010, e Mafalda inédita, no ano de 2013, ambas pela editora Martins 
Fontes, de São Paulo, apresentadas nas figuras dois e três. Esses quadrinhos são passíveis de ampla utilização no meio educacional, incluindo a educação básica, em diferentes componentes curriculares, como, por exemplo: a Geografia, a História e a Língua Portuguesa.

Fig. 2 - Capa da história em quadrinhos Toda Mafalda.

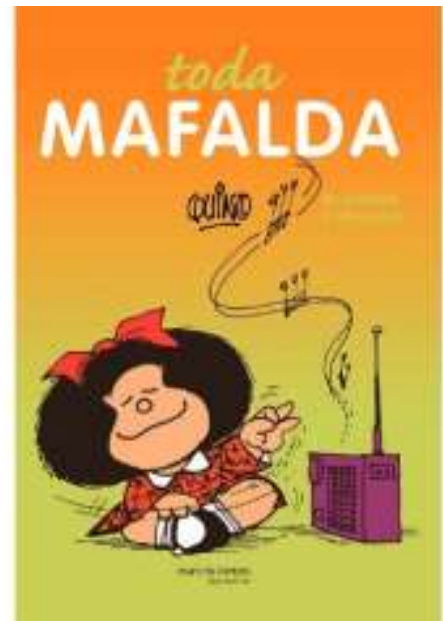

Fonte: acervo do autor.

Fig. 3 - Capa da história em quadrinhos Mafalda inédita.

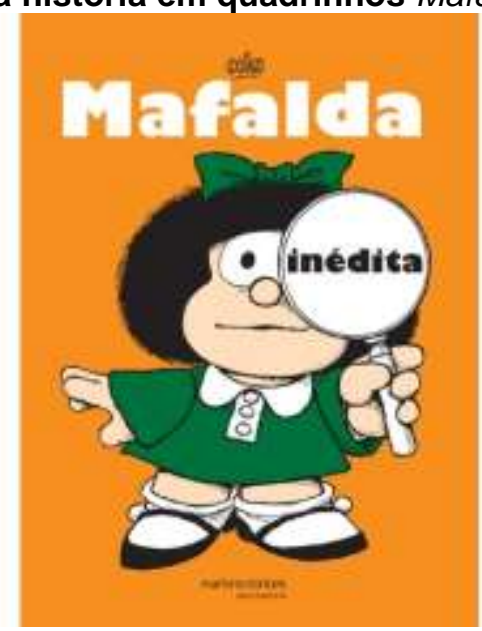

Fonte: acervo do autor.

De acordo com Gociol e Rosemberg (2003), na década de 1970, surgiu no jornal La Nación o personagem Pérez-man, criado por Alberto Bróccoli, que era desenhado como algumas das características de um super-herói, como por exemplo, o fato de possuir uma capa e um aparelho tecnológico em sua orelha esquerda. Contudo, sua problemática de vida retratava um homem comum 
imerso em sua vida cotidiana com as suas vulnerabilidades, o que incluía, por exemplo, seu gosto pelo futebol.

Pérez-man fazia reflexões mal-humoradas e sarcásticas acerca da realidade do dia-a-dia, focando nas questões diárias daquele momento histórico, dialogando diretamente com o leitor das tiras dessas histórias em quadrinhos. Pérez-man preocupa-se, por exemplo, com questões relacionadas à economia, às relações de trabalho e também com o relacionamento com a sua esposa. Sua publicação ocorreu até o início dos anos 1980. Abaixo, a figura quatro apresenta uma tira com este personagem.

Fig. 4 - Tira em que aparece o personagem Pérez-man.
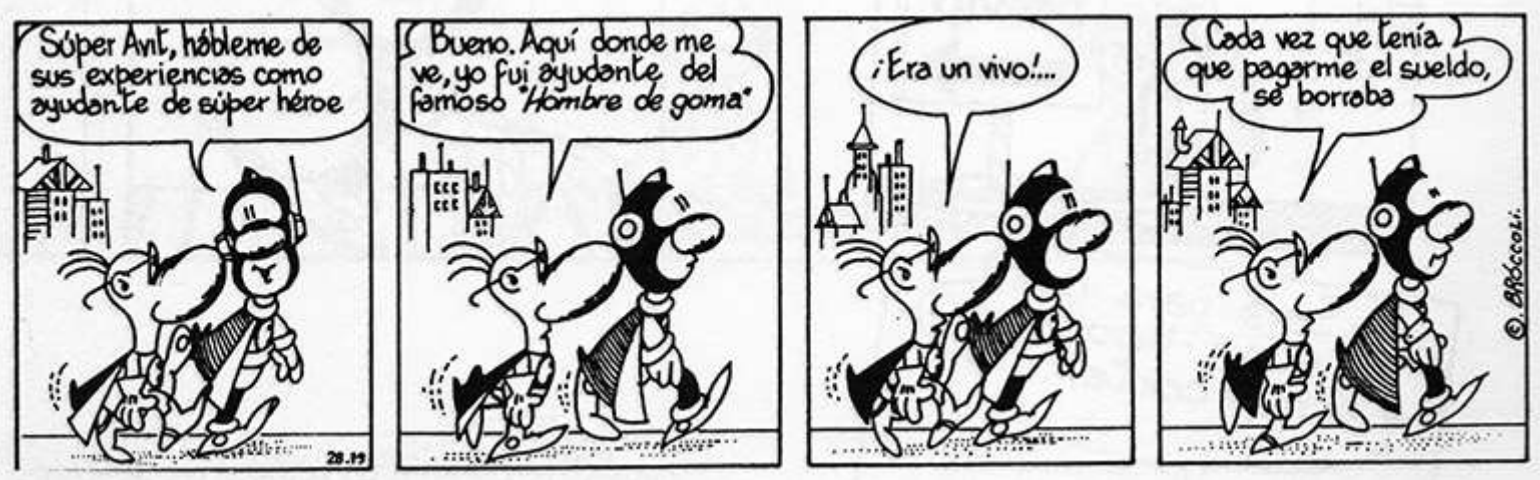

Fonte: Arquivo de llustración Argentina. Disponível em: <https://ilustracion.fadu.uba.ar/2015/11/08/alberto-broccoli/>. Acesso em: 18 nov. 2018.

Também na década de 1970, a produção quadrinística realizada por profissionais argentinos chegou a influenciar, inclusive, os quadrinhos europeus. Como exemplo, Barbieri (2017) menciona as histórias em quadrinhos do roteirista Carlos Sampayo em parceria com o desenhista José Muñoz, como exemplos de trabalhos que aprofundam temáticas psicológicas e sociais em suas produções quadrinísticas, além de um trabalho inovador no plano artístico. Nos termos de Barbieri (2017):

Era como se os dois autores argentinos se apropriassem de todas as inovações linguísticas da fase de tomada de consciência da autonomia dos quadrinhos para voltar a contar 
simplesmente. Havia uma diferença em relação ao contar de dez anos antes, e era evidente: Muñoz e Sampayo já não tinham necessidade de reivindicar a autonomia dos quadrinhos e sua plena capacidade expressiva; simplesmente a usavam. Chegados "depois da revolução", já não precisavam insistir no credo revolucionário: agora era realidade.

Uma boa parte do novo quadrinho italiano deve muitíssimo a Muñoz e Sampayo. É a eles que se deve a atitude neonarrativa [...]. É a atitude pós-revolucionária, pós-vanguardista, de quem quer reconstruir depois das inevitáveis destruições. (BARBIERI, 2017, p. 251-252).

De acordo com Gociol e Rosemberg (2003), nessa mesma época, durante as décadas de 1970 e 1980, surgiram várias revistas argentinas que publicavam histórias em quadrinhos, como as revistas Satiricón, Skorpio e Fierro.

A revista Satiricón passou a ser publicada em 1972 (com direção de Oskar Blotta), possuindo uma linha crítica à realidade social, por vezes fazendo uso da agressividade, do humor negro, da irreverência e da sátira. Focava em temas como a escatologia, o humor negro e a sexualidade. Satiricón, em seu primeiro número, teve uma tiragem de quarenta mil exemplares (vendendo, nesse primeiro momento, cerca da metade desses exemplares). De acordo com Fossati (1997), alguns dos colaboradores dessa revista foram Alberto Breccia e Carlos Trillo.

Gociol e Rosemberg (2003) mencionam que as vendas dessa revista aumentaram de modo gradativo, até obter um número de exemplares vendidos, por tiragem, de cerca de duzentos e cinquenta mil exemplares, quando foi proibida a sua circulação, em outubro de 1974, durante o governo de Maria Estela Martínez de Perón, conhecida como "Isabel" ou "Isabelita" Perón. A figura cinco apresenta uma capa desta revista. 
Fig. 5 - Capa de um exemplar da revista Satiricón.

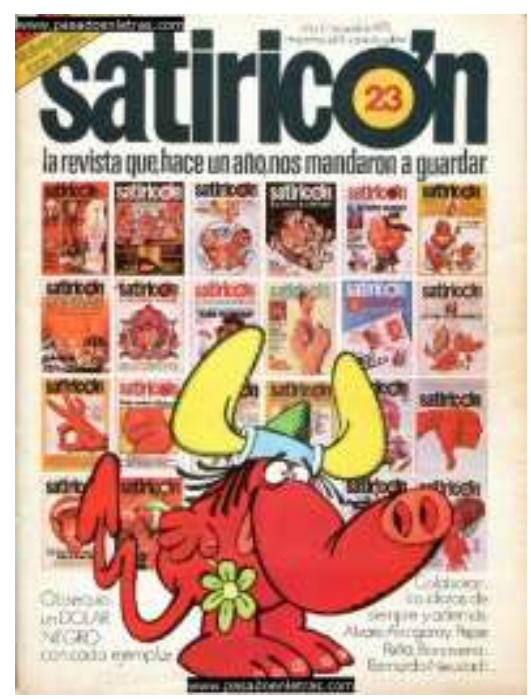

Fonte: Pasado en letras. Disponível em: <http://www.pasadoenletras.com/2014/04/satiricondiciembre-de-1975.html . Acesso em: 18 nov. 2018.

Nesse mesmo ano de 1974 surgiu para o público leitor a revista Skorpio (da editora Record), que produzia conteúdo quadrinístico para o público adulto e que, entre outros, teve como diretor de arte o italiano Juan Zanotto. Essa revista chegou a publicar trabalhos do roteirista Oesterheld e dos desenhistas Francisco Solano López e Hugo Pratt. A figura seis apresenta uma capa desta revista.

Fig. 6 - Capa de um exemplar da revista Skorpio.

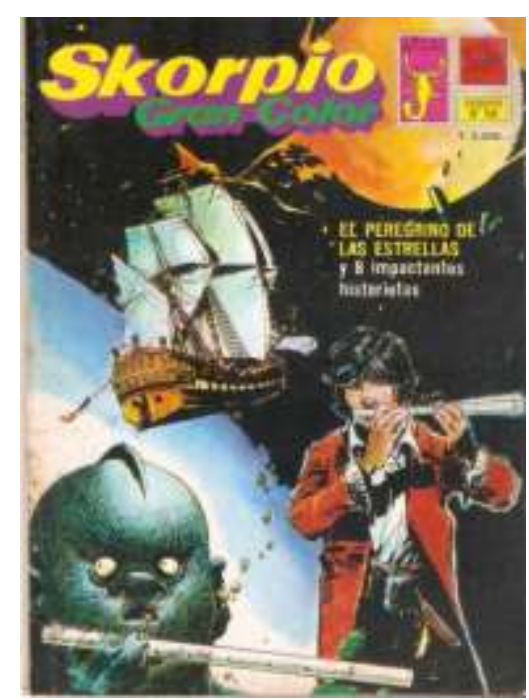

Fonte: Arquivo de llustración Argentina. Disponível em:

<https://ilustracion.fadu.uba.ar/2016/06/03/revista-skorpio/>. Acesso em: 18 nov. 2018. 
No ano de 1984 foi lançada a revista Fierro (da editora La Urraca), que possuía inovações gráficas e textuais, aproximando os quadrinhos, por vezes, de outras áreas, como as Artes Plásticas (em específico, a pintura), o Cinema, a História e a Literatura, por meio de diversas experimentações e fazendo uso dos recursos das histórias em quadrinhos para criar novas formas de linguagem. Talvez seja possível fazer uma relação entre a criação dessa revista e uma maior abertura política na Argentina, o que pode ser um tema para futuras pesquisas nas mais diversas áreas da Arte e da Comunicação, o que inclui os quadrinhos.

A revista Fierro teve como diretores Juan Sasturain e Juan Lima e publicou trabalhos de Alberto Breccia, Carlos Sampayo, Carlos Trillo, Francisco Solano López e José Muñoz, por exemplo. Abaixo, a figura sete apresenta uma capa desta revista.

Fig. 7 - Capa de um exemplar da revista Fierro.

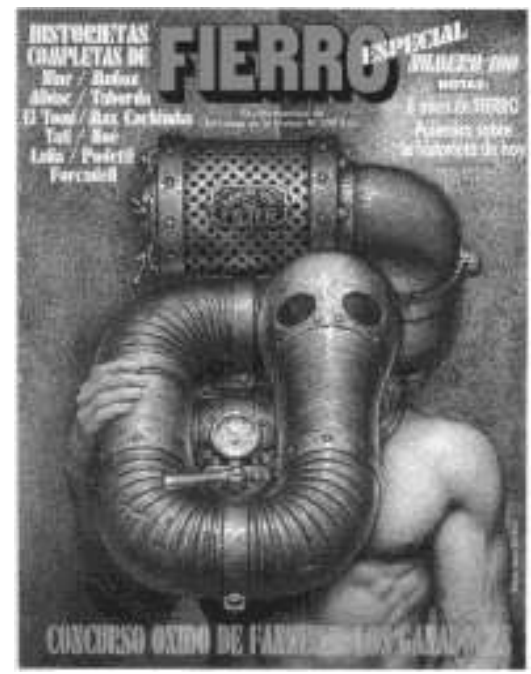

Fonte: acervo do orientador desta tese.

Ainda de acordo com Gociol e Rosemberg (2003), é lembrado que essa publicação chegou a perder uma parcela do público leitor de quadrinhos, justamente em função dessas inovações (em específico, os interessados em apenas ler e acompanhar o desenvolvimento de uma história em quadrinhos 
tradicional). Essa revista Fierro, publicada pela editora La Urraca, teve seu último número publicado em 1992.

Posteriormente, em 2006, a revista Fierro teve a sua publicação e comercialização retomada, trabalhando tanto com quadrinistas argentinos mais experientes, como também com os de uma geração mais recente, sendo publicada até 2017. Nesse segundo período, a revista Fierro foi publicada por meio de um suplemento do jornal Página/12, um dos mais conceituados da Argentina, de linha editorial de esquerda. É adequado ressaltar que, mesmo após o término da publicação da revista Fierro, o jornal Página/12 continua apresentando ao leitor outros quadrinhos.

Também é necessário lembrar a existência da revista Fierro Brasil, em dois volumes, nos anos 2011 e 2012, que também contou com a organização de Juan Sasturain, além de Claudio Roberto Martini.

O álbum Fierro Brasil, volume um, apresenta aos leitores brasileiros autores argentinos, incluindo alguns que estavam presentes na primeira versão da revista Fierro, com histórias em quadrinhos dos gêneros da aventura, da fantasia e do humor, por exemplo. A figura oito apresenta a capa do volume um desta revista.

Fig. 8 - Capa da revista Fierro Brasil (vol. 1).

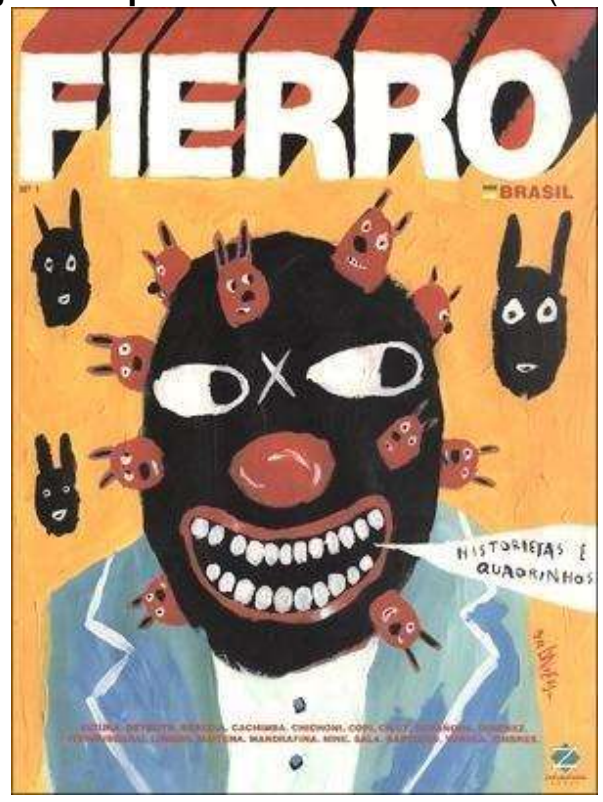

Fonte: acervo do autor. 
O álbum Fierro Brasil, volume dois, é uma antologia de histórias em quadrinhos da revista argentina. Além disso, também conta com trabalhos de quadrinistas latino-americanos, principalmente brasileiros. Essa revista apresenta ao leitor quadrinhos de vários gêneros, com diversas temáticas como os desaparecidos políticos, a ditadura militar, a fantasia e a ficção. A figura nove apresenta a capa do volume dois desta revista.

Fig. 9 - Capa da revista Fierro Brasil (vol. 2).

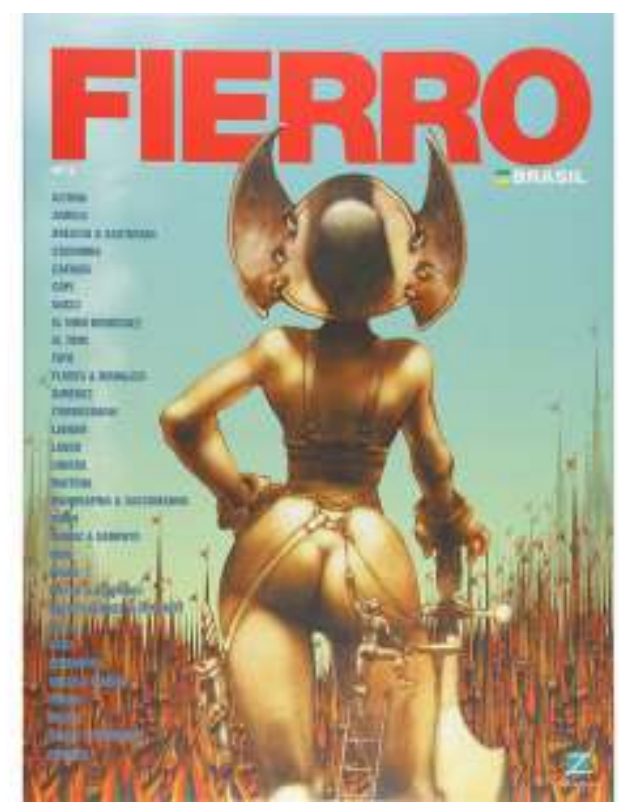

Fonte: acervo do autor.

Esses dois volumes são de extrema importância para o contato dos leitores brasileiros com as histórias em quadrinhos argentinas, em seus mais variados gêneros.

No humor, por exemplo, por meio dos quadrinhos "O Banheiro 1" e "O Banheiro 2" (ambos no volume 1) e, novamente, "O Banheiro 1" e "O Banheiro 2" (ambos no volume 2), do argentino Gustavo Sala ou das histórias do personagem Paolo Pinocchio, nos quadrinhos "Paolo Pinocchio o boneco que mente descaradamente e recebe o que merece...", "Paolo Pinocchio o boneco que mente" e "Paolo Pinocchio 3" (presentes no volume 1) e "Paolo no caldeirão" (no volume 2), do argentino Lucas Varela. 
E também por meio de histórias em quadrinhos mais politizadas, como " $\mathrm{A}$ Família Bolchevique 1" e "A Família Bolchevique 2" (ambos no volume 1) e "A Família Bolchevique" (no volume 2), do argentino El Niño Rodríguez, os quadrinhos "Aquele inverno de 1974" (no volume 2), que conta com o trabalho dos argentinos Carlos Trillo, como roteirista, e Pablo Túnica, como desenhista, e que tem como cenário o período da morte de Juan Perón e a ascensão ao poder de "Isabelita" Perón, fato ocorrido em $1^{\circ}$ de julho de 1974, e também faz referência à Aliança Anticomunista Argentina (AAA - Triple A) e seus assassinatos. A figura dez apresenta um quadrinho desta história.

Fig. 10 - Capa da revista Fierro Brasil (vol. 2).

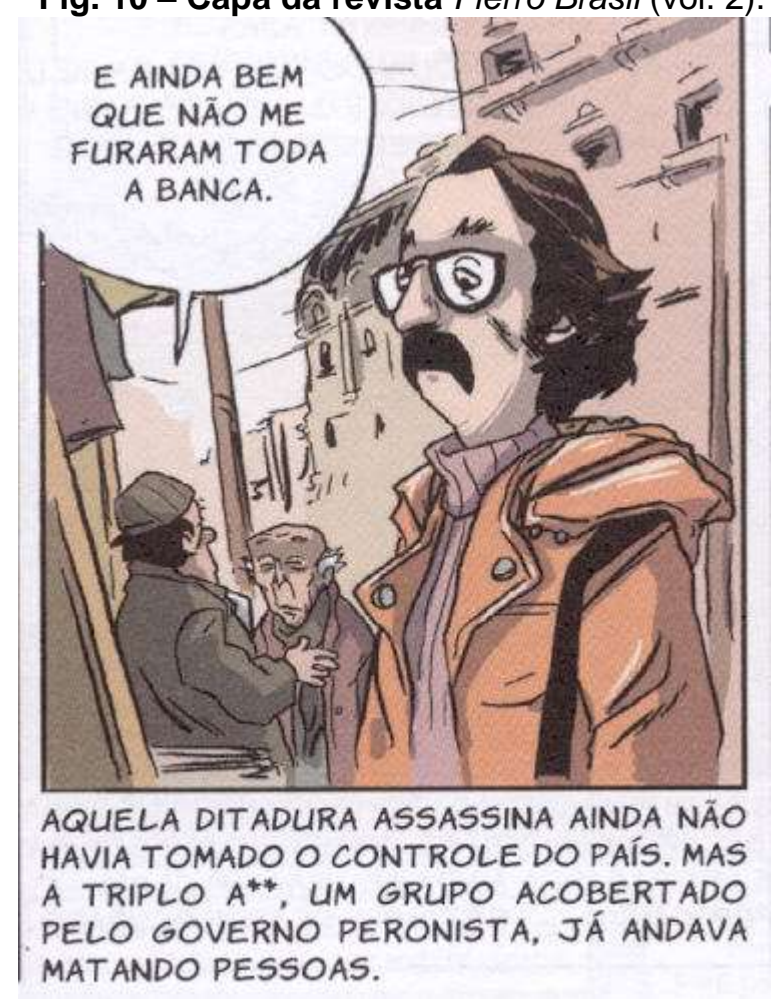

Fonte: acervo do autor.

Um outro exemplo da maior importância é a história em quadrinhos " $\mathrm{H}$ x I (História em quadrinhos pela Identidade)", do roteirista e desenhista argentino Salvador Sanz, que trata do tema dos desaparecidos políticos durante o período repressivo da ditadura militar na Argentina. 
Retomando Gociol e Rosemberg (2003), outro quadrinho de destaque na produção argentina foi Perramus, de Alberto Breccia e roteiros de Juan Sasturain, que foi publicado no primeiro período da revista Fierro, nos anos 1980, e, em grande medida, também trata da resistência da sociedade civil em relação aos repressores da ditadura militar, tanto no plano cultural (simbólico) como no político (militar). Num certo sentido, pode ser considerada uma história em quadrinhos "existencialista", pois trata da condição humana. Também oferece ao leitor reflexões sobre temas como o esquecimento, a memória, o pesadelo e as recordações. Esses quadrinhos foram publicados, quase sempre sem a sua totalidade, em outros países, como a Alemanha, o Brasil, os Estados Unidos e a França.

Também publicada na revista Fierro, a partir do número vinte e um, em maio de 1986, as histórias em quadrinhos Ministerio, de Francisco Solano López e Ricardo Barreiro fazem uma metáfora de uma nação que vive sob uma ditadura, tratando de temas como a burocracia, a dificuldade em aceitar a realidade, a repressão política e a resistência da sociedade civil em relação ao autoritarismo.

Em relação ao Chile, Hasson (2014) fez um levantamento das publicações quadrinísticas entre 1908 e 2000 e apontou, nesse período, a existência de cerca de duzentas e noventa revistas, publicadas por algo em torno de sessenta editoras. Em especial, pode ser considerado o período compreendido entre os anos de 1962 a 1975, pois é considerado la edad de oro da produção de histórias em quadrinhos chilena.

Berth (2017) menciona que no início da década de 1970, durante o período de governo da Unidade Popular de Allende, as histórias em quadrinhos foram utilizadas com o objetivo de transformar atitudes e valores em seus leitores, tratando de temas, para a época, pertinentes ao contexto chileno, como, por exemplo, a reforma agrária.

Nesse momento histórico chileno, as caricaturas políticas e os quadrinhos foram temas de amplo debate intelectual. O governo da Unidade Popular chegou a criar uma empresa estatal intitulada editora Quimantú (por meio da aquisição dos ativos de uma das editoras mais importantes daquele país, 
naquele momento histórico, a Zig-Zag, que já possuía um histórico de produção de quadrinhos com intenso conteúdo de crítica social, expresso então, pelo humor). Quimantú publicou um número significativo de histórias em quadrinhos, promovendo, também a nacionalização dessa produção, incluindo o seu conteúdo, fortalecendo, desse modo, uma abordagem latino-americana. Além disso, também fornecia ao público leitor uma produção quadrinística a preços mais acessíveis (abaixo do mercado).

Hasson (2014) lembra que Quimantú - cujo significado, na língua mapudungun (do povo nativo Mapuche), significa "Sol del saber" - trabalhou com uma equipe de profissionais que buscavam trabalhar com produtos que transmitissem ao leitor novos valores, mais próximos da linha assumida pelo governo Allende. Algumas dessas publicações eram vendidas também na Argentina, no Paraguai e no Peru.

Algumas histórias em quadrinhos publicadas por essa editora foram: Delito, do gênero de suspense, com início de publicação em 1972, cuja numeração foi de cento e onze até cento e trinta e sete; Agente Silencio Aventuras de Marouf, do gênero de suspense, com publicação iniciada em 1971, com numeração que foi de treze a trinta e seis, sendo que a partir do número trinta e sete, já no ano de 1972, essa publicação mudou de nome para Dimensión Cero, do gênero da ficção científica, cuja última numeração impressa foi de cinquenta e sete; El Guerrillero, do gênero histórico, com início de publicação em 1972, cuja numeração foi de cento e trinta e um até cento e cinquenta e quatro.

Fica como observação que algumas das revistas em quadrinhos publicadas por essa editora não começaram do número um pelo fato de serem uma continuação de uma série de outra editora (no caso, da Zig-Zag), ou por serem uma sucessão de uma outra série da própria editora Quimantú, com uma mudança no título (e narrativa) de uma determinada história em quadrinhos que estava sendo publicada.

Vale lembrar também que entre os profissionais que trabalharam na editora Quimantú estavam: Ariel Dorfman (Divisão de Publicações Infantis e Educativas) e Armand Mattelart (Chefe da Seção de Investigação e Avaliação 
de Comunicações de Massa) que, durante o início dos anos 1970, mais precisamente no ano de 1971, portanto no período em que Allende estava no poder, publicaram um livro que representou talvez a mais importante contribuição para uma maior entendimento acerca das temáticas pertencentes aos meios de comunicação de massa e, em específico, ao meio quadrinístico: Para ler o Pato Donald: comunicação de massa e colonialismo, texto esse que estuda a produção da Disney de uma perspectiva mais politizada e crítica. $O$ livro foi publicado no Brasil em 1978, com tradução de Alvaro de Moya.

Contudo, em 11 de setembro de 1973, ocorre um golpe de Estado e os militares que tomam o poder mudam a direção da editora Quimantú e também alteram o seu nome para Editorial Gabriela Mistral. Além disso, essa nova editora decide manter a publicação de apenas quatro títulos de histórias em quadrinhos, com uma alteração de narrativas e personagens.

Posteriormente, em 1975, toda a produção quadrinística dessa editora foi encerrada, dando fim ao período considerado como la edad de oro dos quadrinhos no Chile. A partir de então, ocorre uma debilitação das expressões culturais chilenas e Hasson (2014) chega a utilizar a expressão "apagón cultural", como resultado da ditadura militar de Pinochet, para mencionar tal fato.

Vários anos após o fim dessa ditadura militar, em 2015, foi publicada no Chile a história em quadrinhos Los Años de Allende: novela gráfica, com roteiro de Carlos Reyes e desenhos de Rodrigo Elgueta, pela editora Hueders. Para a elaboração dessa produção quadrinística foi realizada ampla pesquisa, que envolveu tanto a consulta aos historiadores como aos documentos escritos. De acordo com Ojeda (2018), a história em quadrinhos Los Años de Allende também foi publicada na Espanha, na Itália e na Turquia.

Um dos principais méritos dessa história em quadrinhos é o fato de apresentar ao leitor uma articulação das mais diversas percepções acerca do período de Salvador Allende como presidente e, também, do golpe militar de 1973. Essa produção quadrinística valoriza uma pluralidade de vozes que expressam uma multiplicidade de narrações, fornecendo ao leitor as mais variadas visões de mundo (e suas respectivas interpretações) acerca desse 
fato histórico. Realizada em preto-e-branco, possui cento e vinte e oito páginas. Abaixo, a figura onze apresenta a capa desta graphic novel.

Fig. 11 - Capa da história em quadrinhos Los Años de Allende.

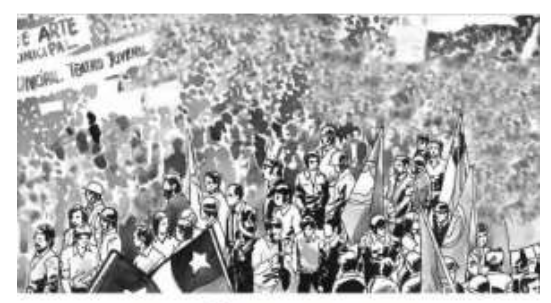

LOS AÑOS DE ALLENDE

nves asica

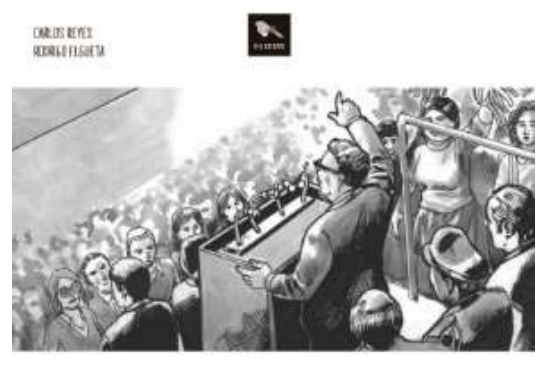

Fonte: acervo do autor.

Essa história em quadrinhos apresenta os principais fatos políticos e os protagonistas (e antagonistas) do governo de Allende, descrevendo a experiência política que envolvia, em uma mesma organização social, o socialismo e a democracia popular. Ela está dividida em cinco partes: 1973, 1970, 1971, 1972 e 1973 (novamente).

O primeiro capítulo, denominado "1973", mostra o golpe militar de Augusto Pinochet, na data de 11 de setembro de 1973. Os demais capítulos, apresentam ao leitor, de modo cronológico, fatos ocorridos durante o período de presidência de Allende, incluindo sua eleição, no Chile, em 1970.

No segundo capítulo, intitulado "1970", os autores caracterizam ideologicamente a população chilena, nesse momento histórico, como pertencente a três grupos políticos principais: a esquerda (PC - Partido Comunista, PS - Partido Socialista, e o MIR - Movimiento de Izquierda 
Revolucionaria), o centro (DC - Democracia Cristã) e a direita (PN - Partido Nacional).

Nesse momento, Allende é o presidente do Senado chileno e candidato a presidente, pela Unidade Popular, sendo, nesse mesmo ano, eleito pelo voto popular. Ocorre também a formação de um grupo paramilitar de direita, chamado Patria y Libertad, que passa a promover atentados terroristas.

Além disso, é narrado o assassinato do general legalista René Schneider, que defendia os princípios constitucionais e legais, a defesa das instituições democráticas, o cumprimento irrestrito da Constituição e, portanto, a posse de Allende na presidência chilena. Collier e Sater (1998) ressaltam a preocupação do general Schneider em garantir eleições sem fraudes e apoiar o presidente que fosse eleito, o que chegou a ficar conhecido como "Doutrina Schneider".

No próximo capítulo, denominado "1971", é apresentado ao leitor a efervescência cultura chilena da época, nas mais variadas áreas, como a música e as artes plásticas, além da intensa mobilização e politização da sociedade como um todo, a política econômica de Allende e também a execução da reforma agrária, além da visita do cubano Fidel Castro e do francês François Mitterrand ao Chile.

Em "1972", retrata um Chile tenso no plano político, com críticas ao governo de Allende por parte de partidos da direita e do centro (Democracia Cristã, por exemplo) e também por parte de uma esquerda mais dogmática (Partido Comunista Revolucionário, por exemplo), além da comprovação da existência de conspirações em curso no exterior, com o objetivo de derrubar o governo eleito. Também relata a ação política violenta de grupos paramilitares de direita. Allende, nesse ano, nomeia três militares para seu gabinete, o que causou descontentamento na esquerda, com manifestações coordenadas pelo MIR.

E, por fim, em "1973", ocorreram eleições no Chile, pelas quais a Unidade Popular aumentava o número de seus deputados (mesmo em um contexto de lutas internas entre os partidos que apoiavam Allende e graves dificuldades econômicas, como o desabastecimento e a inflação). Aparece, também, com 
mais contundência, o aumento do ambiente de tensão econômica e política entre diferentes estratos sociais da sociedade chilena, além das tentativas dos Estados Unidos de influenciar a vida política do Chile, com o início do golpe militar de Pinochet.

No final da narrativa, ironicamente, Allende, que passou toda a sua vida política lutando pelo socialismo de modo democrático, fazendo uso das leis então vigentes, é retratado usando um capacete militar, tentando resistir a um golpe de Estado. Tal fato acrescenta profundidade à narrativa, como é apresentado nas figuras doze e treze:

Fig. 12 - Resistência de Allende ao golpe Militar.

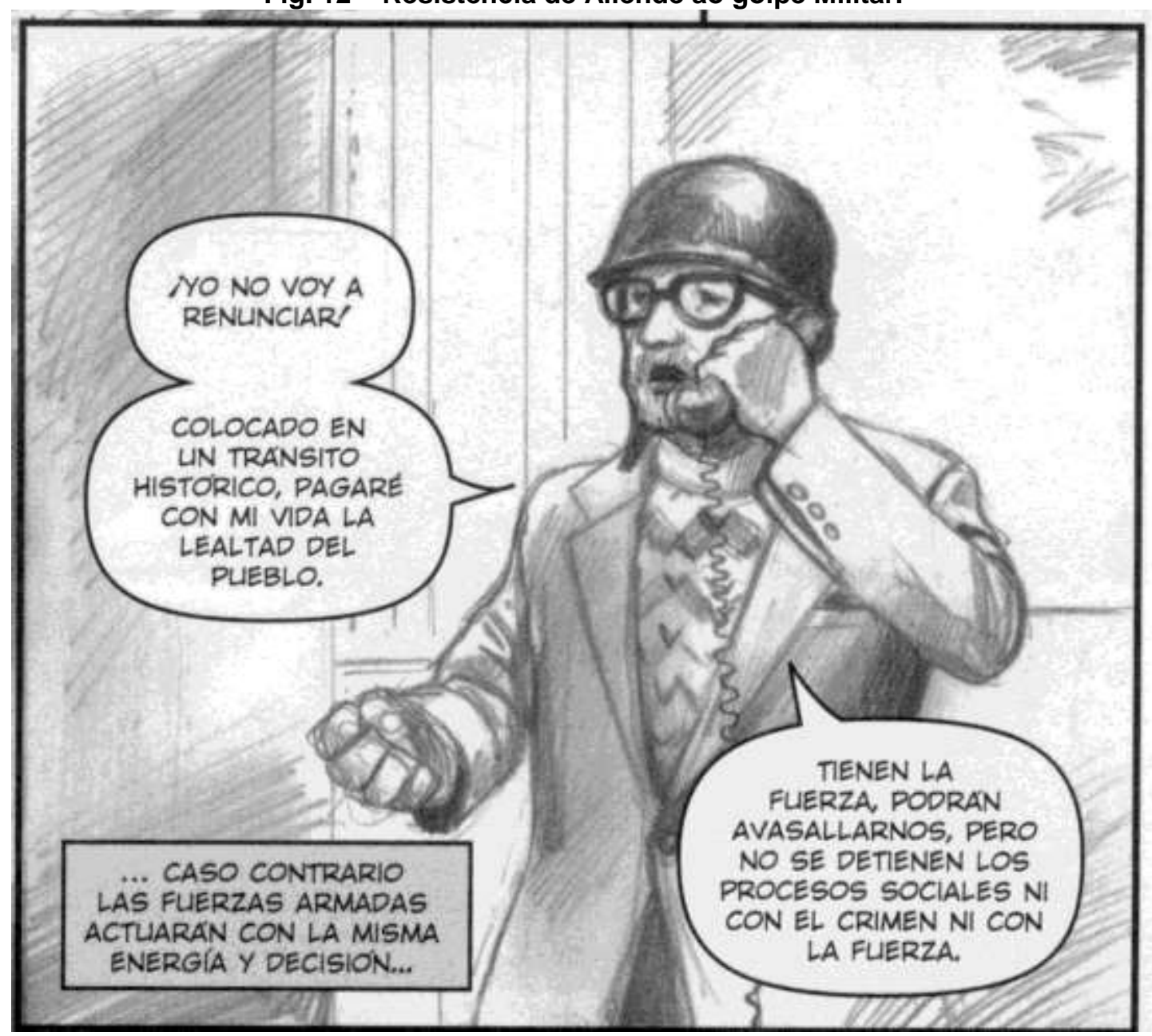

Fonte: acervo do autor. 
Fig. 13 - Discurso de Allende ao povo chileno.

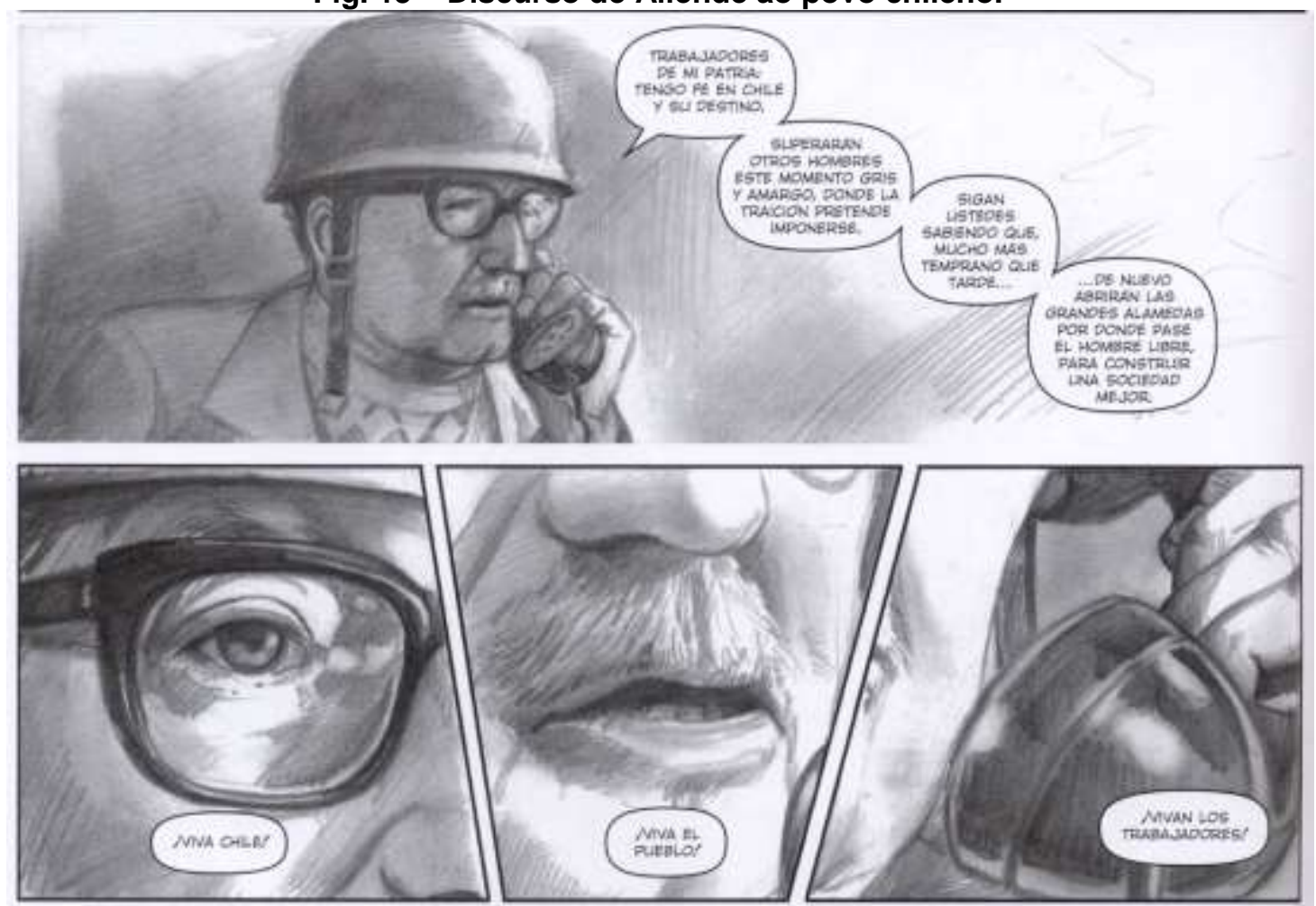

Fonte: acervo do autor.

Outra publicação inovadora dos quadrinhos chilenos é o trabalho artístico Anticristo, de Javier Rodríguez Pino, publicado em formato livro, em 2017. Nesse volume de noventa e seis páginas, em preto-e-branco, o autor faz uso tanto das histórias em quadrinhos, como também de imagens com legendas (situadas na parte inferior das páginas), focando sobre temáticas próprias das Ciências Sociais, em específico acerca dos cenários de violência política chilenas, promovendo, desse modo, uma discussão acerca da memória coletiva e da História, por meio de um discurso visual.

Essa produção de arte política latino-americana, tem o relevante papel social de ampliar e enriquecer a reflexão e o entendimento acerca das problemáticas dessa sociedade, devido ao seu caráter plural no uso de diferentes linguagens e processos de comunicação, ao tratar de diversas formas de como perceber a realidade social e política, principalmente pelo uso da linguagem visual.

O autor chama a atenção para a complexidade das possíveis leituras dessas imagens, com o objetivo de causar no público leitor sensações de 
incerteza e inquietude. Além disso, a publicação Anticristo também traz ao leitor dois artigos (ambos escritos em espanhol e em inglês), de autoria de dois importantes escritores chilenos: Carolina Olmedo Carrasco e Rodolfo Andaur.

No primeiro artigo, Olmedo Carrasco (2017) chega a apontar o trabalho artístico de Rodríguez Pino como sendo de "resistência cultural" à dominação capitalista, além de "despertar a autonomia latino-americana frente à submissão do colonialismo cultural" (OLMEDO CARRASCO, 2017, p. 6, tradução nossa) ${ }^{8}$, num esforço para revitalizar o debate público acerca de diversos temas, como a ditadura militar e a resistência civil aos processos de opressão cultural e social. Nos termos de Olmedo Carrasco (2017): “Anticristo busca restaurar a um público massivo a pergunta pela consciência histórica através do livro-quadrinho como suporte, assumindo a necessidade de enfrentar os vazios na memória histórica" (OLMEDO CARRASCO, 2017, p. 7, tradução nossa) $)^{9}$.

A autora também ressalta que embora Anticristo seja um relato ficcional, pois Rodríguez Pino trabalha tanto com personagens reais e inventados, essa narrativa é alicerçada fundamentalmente por elementos reais, tais como as execuções de membros da sociedade civil no Chile, durante o período da ditadura militar de Pinochet, e o esquecimento desses fatos políticos, por parte de amplas camadas sociais, com o passar do tempo.

Desse modo, Rodríguez Pino usa as histórias em quadrinhos como um instrumento pedagógico, como uma forma de esclarecimento do público leitor acerca de várias problemáticas históricas que, de diversos modos, ainda impactam na vida cotidiana chilena e latino-americana.

Portanto, ao trabalhar com as temáticas da repressão e da violência política nas últimas décadas, o livro de Rodríguez Pino contribui para um maior entendimento, acerca desses temas, na atualidade das classes que vivem do trabalho, pois a arte visual desse autor colabora para uma formação mais

\footnotetext{
${ }^{8}$ Despertar a la autonomia latino-americana frente a la sumisión del colonialismo cultural.

${ }^{9}$ Anticristo busca restaurar a un público masivo la pregunta por la conciencia histórica a través del libro-comic como soporte, asumiendo la necesidad de enfrentar los vacíos en la memoria histórica.
} 
ampla e problematizada do imaginário social, ao fazer uso de uma estética vinculada aos quadrinhos.

No segundo artigo, Andaur (2017) menciona o uso que Rodríguez Pino faz uso dos desenhos, para abordar os fatos históricos, favorecendo um maior entendimento acerca do cenário em que surgiu uma violência desmedida, por parte desse Estado autoritário, possibilitando, com isso, uma discussão sobre o tema dos direitos humanos.

Ou seja, para Andaur (2017), Rodríguez Pino é um artista que faz uso das imagens para aprofundar a discussão sobre a história política, buscando envolver o público leitor com um ambiente de tensão social e auxiliando, desse modo, na construção de um imaginário social mais problematizado acerca da História recente.

Pode-se concluir que Anticristo é um trabalho visual que busca ultrapassar os limites convencionais de observação acerca dos fatos políticos ao desenvolver novas maneiras de visualização das problemáticas que envolvem as classes sociais, fazendo uso, ao mesmo tempo, de imagens e textos, com ênfase nos desenhos, sendo, portanto, uma relevante contribuição para a área da cultura visual. Rodríguez Pino faz uso da estética expressionista nesse seu trabalho artístico. Tal fato pode ser visualizado nas figuras quatorze (a tira), quinze (quadrinho um da tira) e dezesseis (quadrinhos dois e três da tira):

Fig. 14 - Rodríguez Pino e o uso do expressionismo.

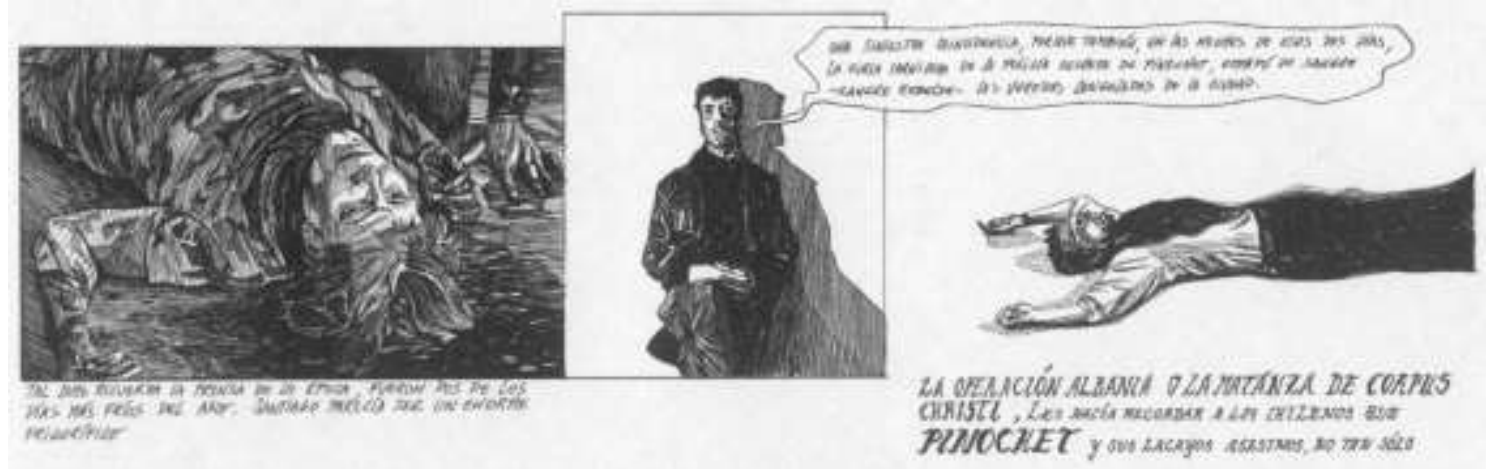

Fonte: acervo do autor. 
Fig. 15 - Quadrinho um da tira apresentada na figura quatorze.

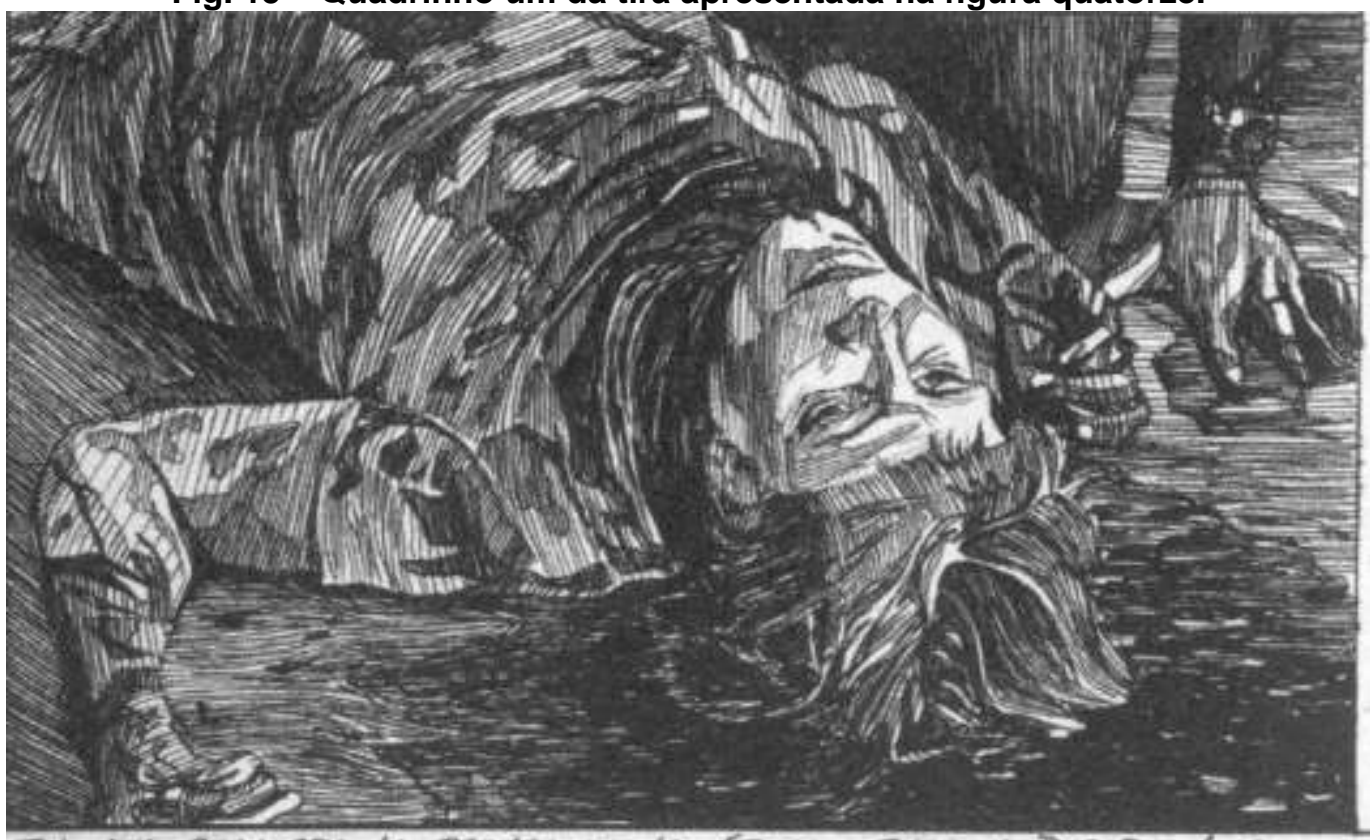

TAL COHO RECUERDA LA PRENSA DE LA ETOCA, FVERON DOS PE LOS DIAS MA'S FKIOSS DEL ANOO. SANTIALO PARECIA SER UN ENORME FRIGORIFico

Fonte: acervo do autor.

Fig. 16 - Quadrinhos dois e três da tira apresentada na figura quatorze.

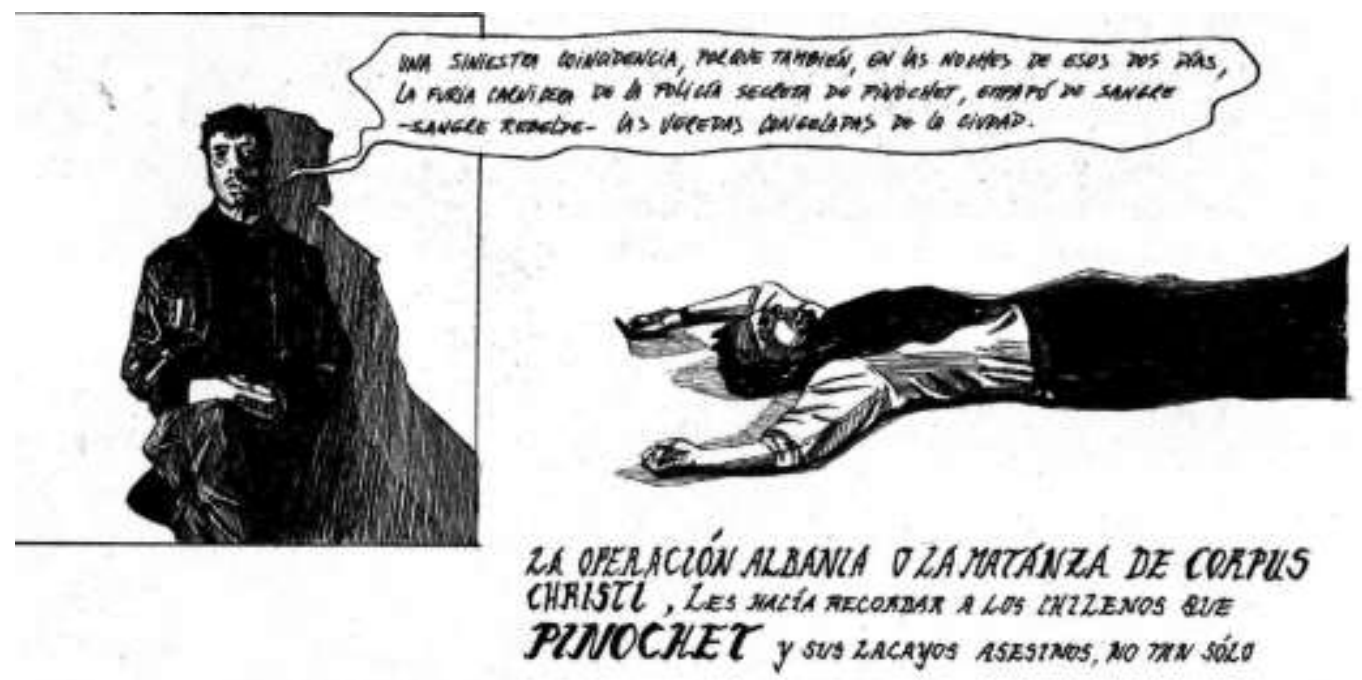

Fonte: acervo do autor.

Nessas imagens, o autor trata da "Operação Albânia", na qual ocorreu o assassinato de doze militantes socialistas, pertencentes à Frente Patriótica Manuel Rodríguez, por policiais e militares, em 1987, durante a ditadura militar 
de Pinochet. Tal fato é narrado nos quadrinhos da figura dezessete. Também é adequado observar que o artista Rodríguez Pino aparece como um dos personagens da narrativa de Anticristo: na figura dezessete, no canto inferior direito (esse mesmo recurso de comunicação com o leitor já havia sido utilizado em El Eternauta e, de modo mais incisivo, em El Eternauta II, ambos de Oesterheld em parceria com Solano López).

Fig. 17 - Conflitos político no Chile, durante a ditadura militar de Pinochet.

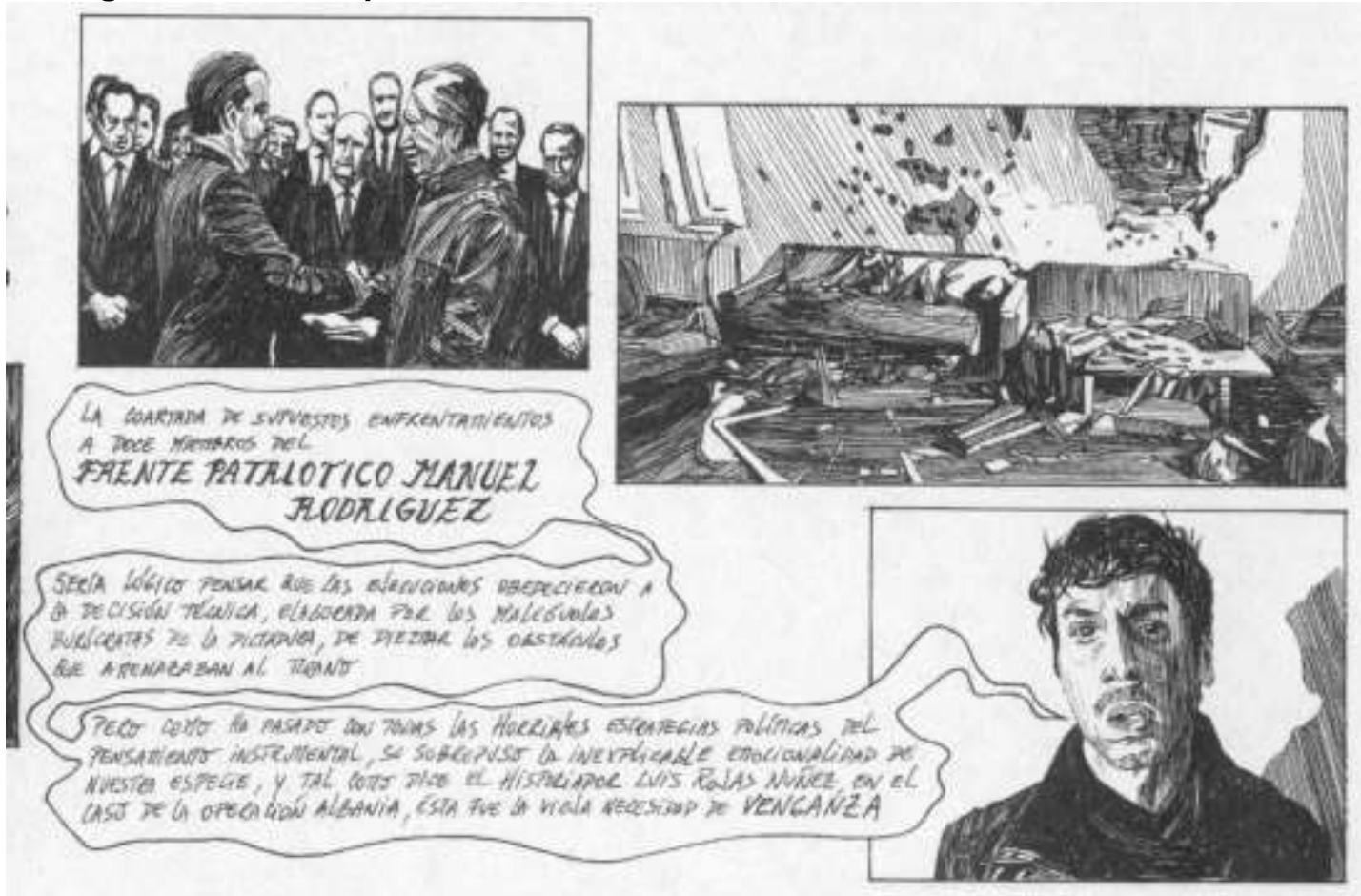

Fonte: acervo do autor.

Mais recentemente, no ano de 2018, o jornal chileno The Clinic - que iniciou a sua publicação em 23 de novembro de 1998, segundo Hasson (2018) - atualmente de periodicidade semanal e linha editorial independente, e que foca principalmente em temáticas culturais e políticas, tem publicado os quadrinhos "Piñericosas", que chamam a atenção tanto pela sua simplicidade gráfica, como também pela crítica mordaz e satírica ao presidente chileno Sebastián Piñera, que ascendeu ao poder, para um segundo mandato, em 11 de março de 2018 (o primeiro mandato ocorreu entre 11 de março de 2010 e 11 de março de 2014). Além disso, em sua edição número 749 (ano 19), 
publicada em 31 de maio de 2018, esse jornal, The Clinic, trouxe ao leitor, em uma página inteira, uma contribuição do desenhista Ricardo Fuentealba, pertencente ao movimento underground dos quadrinhos chilenos, imagem essa que também trabalha com a memória coletiva dos leitores, acerca do golpe de Estado ocorrido no Chile, em 1973.

$\mathrm{Na}$ produção quadrinística chilena também se destaca a produção de adaptações literárias, por diferentes editoras, como Origo, Planeta Comic e Ocho Libros. Um exemplo, é a publicação, em quadrinhos, da obra do reconhecido escritor chileno Jenaro Prieto, El Socio. Prieto foi um profundo estudioso da sociedade chilena, por meio de uma perspectiva ideológica de direita (inclusive, pertenceu ao Partido Conservador, na década de 1930).

A graphic novel El Socio contou com roteiro e ilustrações de Fabián Todorivic, foi feita em cores e apresenta doze páginas (o romance publicado pela Sociedad Chilena de Ediciones, em sua segunda edição, possui duzentas e vinte e três páginas). A figura dezoito apresenta a capa desta graphic novel.

Fig. 18 - Capa da história em quadrinhos El Socio.

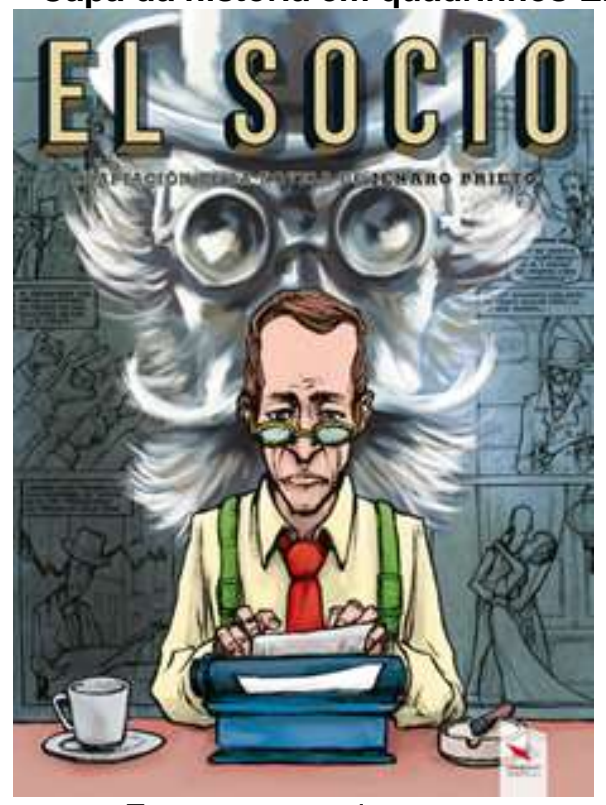

Fonte: acervo do autor.

Essa graphic novel demonstra, como exemplo empírico, a singularidade dos quadrinhos, como meio de comunicação. Embora tenha doze páginas, é 
uma contribuição significativa para a leitura desse romance, ao fazer uso, em uma mesma publicação, de imagens e textos, em conjunto.

O romance El Socio trata da especulação financeira na bolsa de Santiago e, num contexto mais amplo, do crescimento (e da crise) econômica, além de ter como pano de fundo um relevante papel exercido pela imprensa escrita, na época. Foi publicado, pela primeira vez, em 1928. A figura dezenove apresenta um diálogo entre o protagonista desta história (Julián Pardo), numa reflexão acerca de suas possíveis ações futuras, com o personagem Samuel Goldenberg.

Fig. 19 - Os personagens Julián Pardo (à esquerda) e Samuel Goldenberg (à direita).

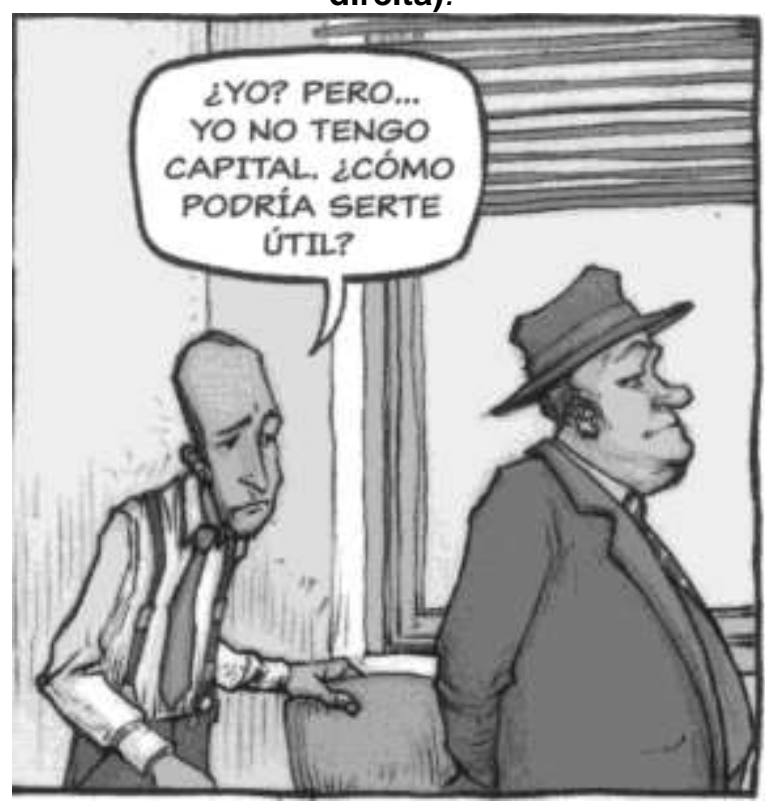

Fonte: acervo do autor.

No Peru, de acordo com Drinot (2017), apareceram os quadrinhos intitulados El Cuy, do gênero "funny animals", de Juan Acevedo, na publicação El Diario de Marka, em 1980. Esse era o principal diário do Peru, com linha editorial de esquerda, no início dos anos 1980. Quadrinhos com alto patamar de politização, eles apresentavam ao leitor a temática do fracionamento da esquerda no Peru, o que incluía, por exemplo, a discussão sobre o engajamento nas disputas eleitorais ou a insurreição armada. 
Ao redor de 1982, esses quadrinhos começaram a tratar também da ascensão da guerrilha Sendero Luminoso, que chegou a ser representada nas tiras quadrinísticas por meio do personagem Senderito, que possuía as características de ser ativo, dogmático e implacável. Ou seja, são justamente as características que eram atribuídas aos membros desse grupo armado que buscava derrubar os governos nacionais peruanos durante os anos $1980 \mathrm{e}$ início dos 1990, para implantar uma nova organização societária, socialista, sem a propriedade privada dos meios relevantes de produção.

Desse modo, pode-se concluir que as histórias em quadrinhos El Cuy tinham a capacidade de apresentar ao leitor um conjunto significativo de discussões sobre o cenário econômico, político e social que ocorria naquele momento na sociedade peruana. Nesse sentido, Drinot (2017) afirma que os quadrinhos El Cuy realizam um debate de ideias, trabalhando, desse modo, em favor de uma educação política. Portanto, é reafirmado que as histórias em quadrinhos têm a capacidade de influenciar como os atores sociais pensam $e$ agem no interior de um determinado contexto societário. A figura vinte apresenta uma tira destes quadrinhos.

Fig. 20 - Tira dos quadrinhos El Cuy.
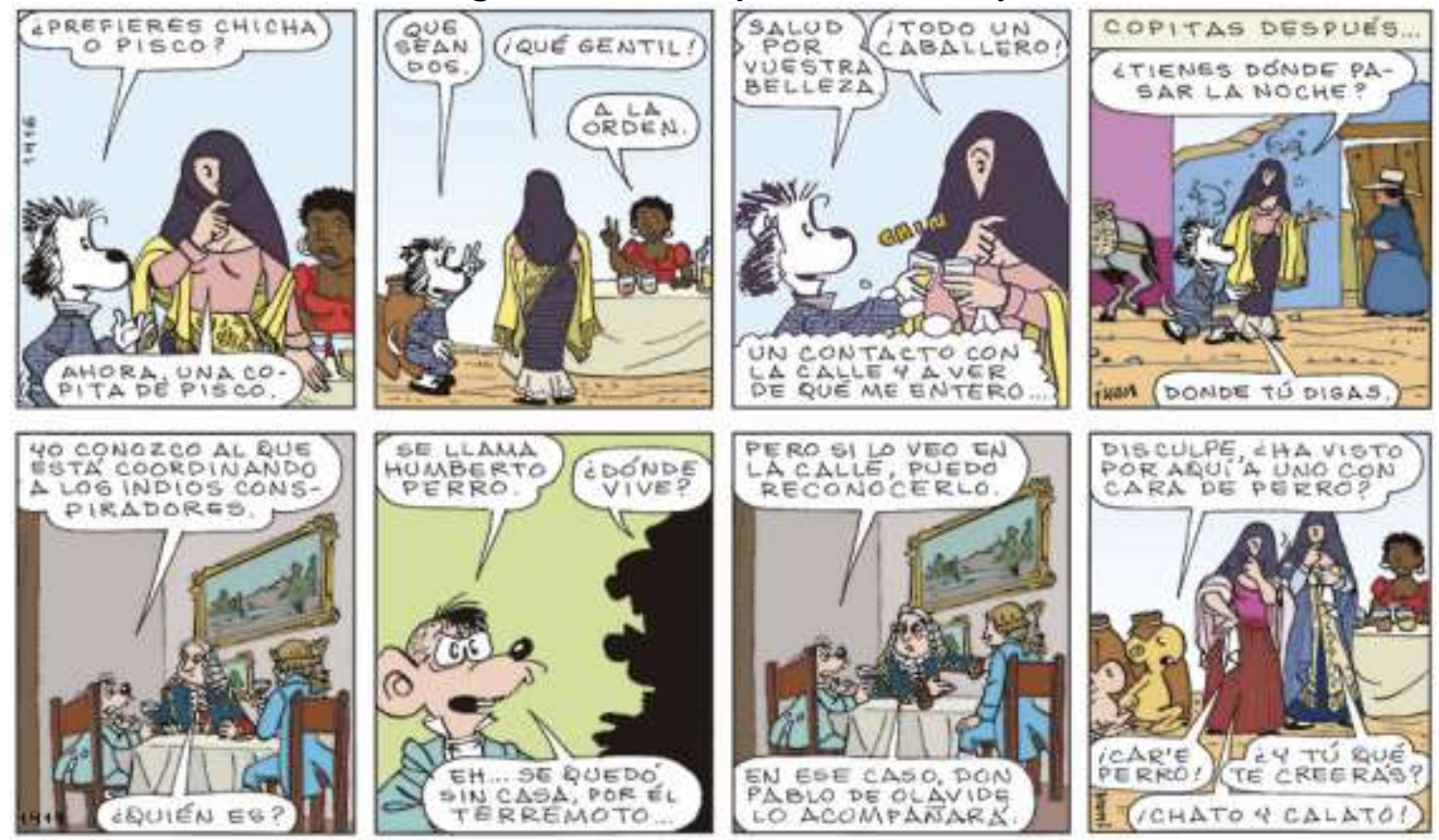

Fonte: El Diario del Cuy. Disponível em:

<https://elcuy.files.wordpress.com/2018/09/tiras-1416-y-1417-color.jpg>. Acesso em: 17 dez. 2018. 
Outras duas histórias em quadrinhos que retratam o conflito entre 0 Sendero Luminoso e os agentes do Estado Peruano são: Rupay: historias de la violencia política em Perú, 1980-1984, de autoria de Luis Rossell, Alfredo Villar e Jesús Cossio e Barbarie: comics sobre violencia política en el Perú, 1985-1990, também de Jesús Cossio. Essas duas histórias em quadrinhos foram publicadas no Brasil, pela editora Veneta, em 2016, num volume único predominantemente em preto-e-branco, numa publicação que possui duzentas e oito páginas, intitulada Sendero Luminoso: história de uma guerra suja. A seguir, na figura vinte e um, é apresentada a capa desta história em quadrinhos.

Fig. 21 - Capa da história em quadrinhos Sendero Luminoso.

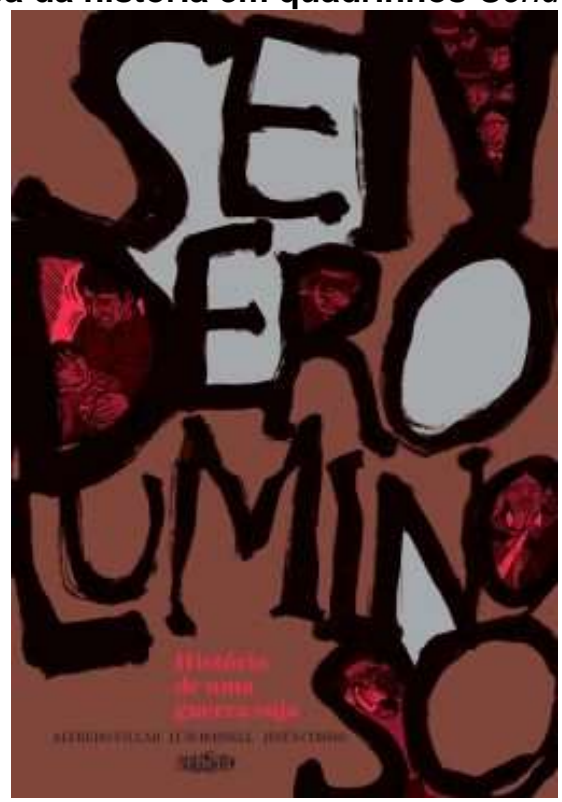

Fonte: acervo do autor.

Segundo Pérez-del-Solar (2012), os quadrinhos Rupay: historias de la violencia política en Perú, 1980-1984 apresentam estratégias típicas de um contexto de "guerra suja", com a sistemática violação dos direitos humanos, o que inclui, por exemplo, a existência de torturas e assassinatos.

Tanto os quadrinhos Rupay: historias de la violencia política en Perú, 1980-1984 como Barbarie: comics sobre violencia política en el Perú estão divididos de modo a que cada história apresente um caso de violência política. Pérez-del-Solar (2012) ressalta que a combinação de alguns dos recursos 
quadrinísticos, ou seja, nesse caso, a imagem e o texto, apresenta ao público leitor uma denúncia dos fatos ocorridos, lutando, desse modo, para que não ocorra uma situação de indiferença em relação aos crimes cometidos e, até mesmo, de uma cumplicidade em relação a esses fatos trágicos. O autor também aponta que uma das condições para a existência da violência é a injustiça social.

Portanto, nesse artigo, existe um alerta para o fato de que, enquanto existir uma concentração de riqueza nas mãos de uma elite, combinada com a miséria absoluta da maioria significativa da população, existe um fator que pode desencadear, novamente, essa violência política.

Milton (2017) também analisa os quadrinhos Rupay: historias de la violencia política en Perú, 1980-1984, afirmando que essa história em quadrinhos apresenta uma construção de uma narrativa acerca do passado, como parte de um processo de esclarecimento histórico, buscando, desse modo, evitar a formação de memórias isoladas acerca do ocorrido (o que origina diversas versões sobre um mesmo fato histórico) ou, até mesmo, a formação de rumores sobre o acontecido.

Vale ainda ressaltar que Rupay: historias de la violencia política en Perú, 1980-1984 é um trabalho diferenciado em relação a outros quadrinhos que tratam desse mesmo tema, pelo fato de, na sua elaboração, terem sido utilizadas tanto as publicações existentes (os registros históricos), como também fontes digitais que tratam desse conflito político no Peru, além de fazer uso do relatório final da Comisión de la Verdade y Reconciliación. Tal preocupação com a pesquisa acerca desse conflito, promove essa história em quadrinhos a um documento cultural, baseado em fatos reais e também documentado, sobre esse conflito interno peruano.

Inclusive, Milton (2017) aponta uma vantagem da história em quadrinhos Rupay: historias de la violencia política en Perú em relação ao relatório final da Comisión de la Verdade y Reconciliación, pois nos quadrinhos são apresentadas as falas de diversos personagens do conflito armado, incluindo os senderistas, os camponeses, os agentes do Estado e os jornalistas - o que permite o confronto de diferentes versões sobre um mesmo fato -, enquanto 
que o relatório acerca do conflito armada é redigido por um grupo de pesquisadores que "relata" e "interpreta" os acontecimentos.

Ou seja, esses quadrinhos têm a vantagem, em relação ao relatório final da Comisión de la Verdade y Reconciliación, de apresentar várias vozes (e diversos registros dos fatos ocorridos), com os seus respectivos pontos de vista, o que demonstra a peculiaridade e a riqueza desta história em quadrinhos. Porém, Milton (2017) lembra também que seria impossível para a Comisión de la Verdade y Reconciliación apresentar esses diálogos, sem as respectivas provas documentais.

Com isso, é possível afirmar que Luis Rossell, Alfredo Villar e Jesús Cossio não buscaram a formulação, nesses quadrinhos, de uma narrativa única acerca desse conflito armado em território peruano, apresentado um mesmo fato por diversas perspectivas.

Desse modo, a leitura desses quadrinhos fornece ao público leitor, por meio das imagens e do roteiro, várias formas de exposição (e interpretação) deste conflito armado, fazendo uso, portanto, dos vários mecanismos interpretativos das histórias em quadrinhos, que são próprios deste meio de comunicação.

No Brasil, entre as três primeiras décadas de uma produção mais ampla de histórias em quadrinhos (em específico, no período que vai de 1934 até 1960), verifica-se a predominância muito significativa de quadrinhos voltados quase que exclusivamente para o público infantil e juvenil, além de uma influência dos quadrinhos estadunidenses, que tinham como objetivo fornecer entretenimento ao leitor brasileiro. Além disso, também é necessário ressaltar a repressão às histórias em quadrinhos, o que ocorria já na década de 1940, por meio de ameaças de censura e restrições às suas publicações.

Um exemplo ocorreu, de acordo com Silva Junior (2004), na cidade de São Paulo, onde o então vereador Jânio Quadros conseguiu a "aprovação para a redação final de seu projeto de lei no 90/48", que tinha como objetivo "impedir que as leituras atentatórias aos bons costumes continuem a ser expostas nas livrarias e bancas de jornais". 
Posteriormente, no início da década de 1960, as quatro principais editoras brasileiras de histórias em quadrinhos adotaram um "código de ética" em relação aos quadrinhos. Esse documento proibia que os quadrinhos tratassem, por exemplo, de temas políticos e também da violência, além de não admitir ofensas a valores morais e religiosos. As editoras Abril, EBAL, O Cruzeiro e RGE, além da Record, concordaram no uso de um selo em suas revistas. A RGE foi a editora que usou o selo em suas publicações por um maior período de tempo, até o ano de 1971.

Essa auto-regulamentação pode ser entendida como um retrocesso marcante na produção de quadrinhos brasileiros, pois afetou justamente o que era, potencialmente, mais criativo e inovador em termos de desenhos e narrativas das histórias em quadrinhos.

Por outro lado, um movimento surgido nos Estados Unidos e que depois atingiu dimensões mundiais, conhecido como underground, que representou uma forma de resistência política e também de vanguarda cultural e que ocorreu principalmente nas décadas de 1960 e 1970 sendo expresso, por exemplo, pelo estilo de vida punk, também influenciou o mundo dos quadrinhos, inclusive no Brasil.

Um exemplo da maior importância que merece ser mencionado, no que se refere a influência underground no Brasil, foi o jornal de periodicidade semanal O Pasquim, publicado entre junho de 1969 e novembro de 1991. Posteriormente, nos anos de 2006 e 2007, a editora Desiderata levou ao mercado uma coleção de trechos do jornal $O$ Pasquim, em dois volumes: 0 primeiro (com publicações que vão de 1969 até 1971) e o segundo (com publicações entre 1972 e 1973).

Esse jornal, de linha editoral crítica e de "resistência cultural", usava histórias em quadrinhos (e, num sentido mais amplo, o humor gráfico, incluindo as caricaturas políticas) na sua resistência e oposição à ditadura militar brasileira e reuniu colaboradores como Antônio Callado, Chico Buarque de Hollanda, Glauber Rocha, Jaguar, Rubem Fonseca, Tarso de Castro e Ziraldo. É importante ressaltar que alguns membros da equipe desse jornal chegaram a ser presos durante o período desse regime militar. Ou, dito em outros termos: 
No Brasil, a influência do quadrinho underground pode ser encontrada [...] nas colaborações dos vários participantes do semanário $O$ Pasquim, do Rio de Janeiro, em que as audaciosas alfinetadas nos representantes ou nos (mal)feitos da ditadura militar eram retratados por traços econômicos e esteticamente desafiadores, numa composição que se afastava de cânones mais tradicionais e adentrava pelo universo da caricatura e da sátira [...]. Essa utilização das histórias em quadrinhos como instrumento de crítica política - mas não exclusivamente delas, uma vez que a revista $O$ Pasquim igualmente abria espaço para a charge, o cartum, a crônica -, também realizava a crítica de costumes, principalmente à classe média acomodada, tão necessária à sociedade da época. (VERGUEIRO, 2017, p. 20).

Em relação ao Pasquim, é importante destacar o trabalho de um de seus mais distintos colaboradores Henfil (Henrique de Souza Filho), no âmbito da produção de histórias em quadrinhos, caricaturas políticas e charges, além de também exercer as ocupações de escritor e jornalista. Henfil atuou na luta em favor da abertura política e término da ditadura militar no Brasil, por meio de análises profundas do cotidiano brasileiro, tendo, com isso, uma participação ativa nos movimentos sociais brasileiros. Alguns dos seus personagens mais conhecidos foram "os Fradinhos".

Posteriormente, em um outro momento da história brasileira, é relevante mencionar o trabalho com charges e quadrinhos de Carlos Latuff, que trata, entre outros assuntos, da temática da política agrária e da violência do campo no Brasil, o que envolve, portanto, uma preocupação com a justiça social e com discussões acerca das classes sociais realizadas por meio do discurso imagético, fazendo uso tanto da ironia como da sátira. Sua produção de charges tem repercussão internacional, chegando, inclusive, a receber 0 Prêmio Melhor Charge, com sua produção "Once Upon a Time", na cidade de Rafah (Palestina), em 2011.

Além disso, também digno de nota na produção quadrinística brasileira são as adaptações de obras literárias (tanto brasileiras como mundiais). Desse modo, torna-se possível uma comparação entre as histórias em quadrinhos e os textos literários que as originaram.

Tal trabalho é feito, por exemplo, pela editora Ática. Uma de suas publicações, A Escrava Isaura, do romancista Bernardo Guimarães, contou 
com roteiro de Ivan Jaf e arte de Eloar Guazzelli Filho. Essa adaptação literária apresenta o período de reinado de Dom Pedro II e a problemática social do autoritarismo, da escravidão (e do movimento abolicionista), além da valorização da riqueza monetária. Esse volume foi publicado com setenta e duas páginas, em cores, no ano de 2010. A figura vinte e dois apresenta a capa desta publicação.

Fig. 22 - Capa da adaptação literária $A$ Escrava Isaura.

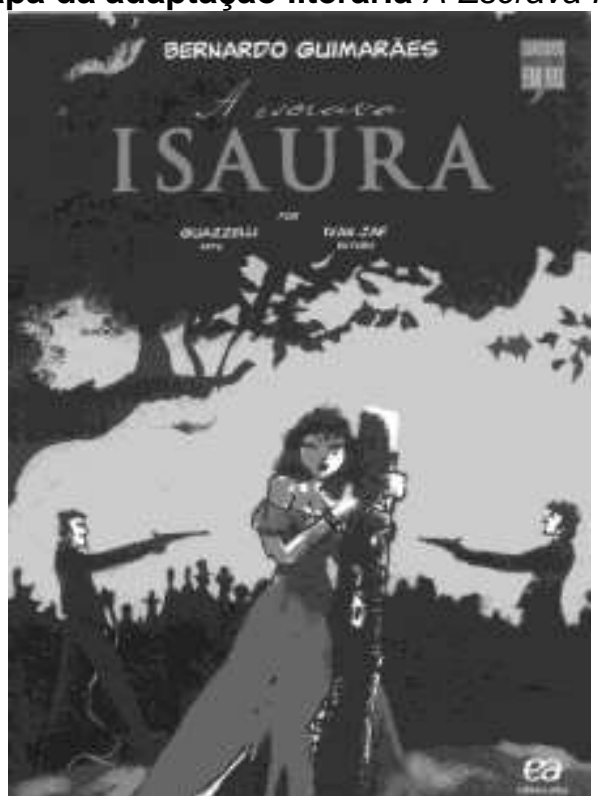

Fonte: Sistema Municipal de Bibliotecas Públicas da cidade de São Paulo.

Além das adaptações literárias de obras brasileiras (e, portanto, latinoamericanas), existem algumas que chegam a romper os limites desta região geográfica, contribuindo, desse modo, por meio dos recursos gráficos e da arte latino-americana, com uma releitura e valorização de romances de vários locais do mundo. Tal trabalho é feito, por exemplo, pela editora Peirópolis, que produz adaptações literárias por meio da coleção Clássicos em $\mathrm{HQ}$, que em seu décimo sexto título trouxe ao leitor a graphic novel Fausto em quadrinhos, de Johann Wolfgang von Goethe, um dos principais nomes da literatura em todo o mundo. Essa história em quadrinhos contou com roteiros de Leonardo Santana, ilustrações de Rom Freire e coloração de Dinei Ribeiro, sendo 
publicada com noventa em seis páginas, em cores, no ano de 2017. A figura vinte e três apresenta a capa desta graphic novel.

Fig. 23 - Capa da história em quadrinhos Fausto em quadrinhos.

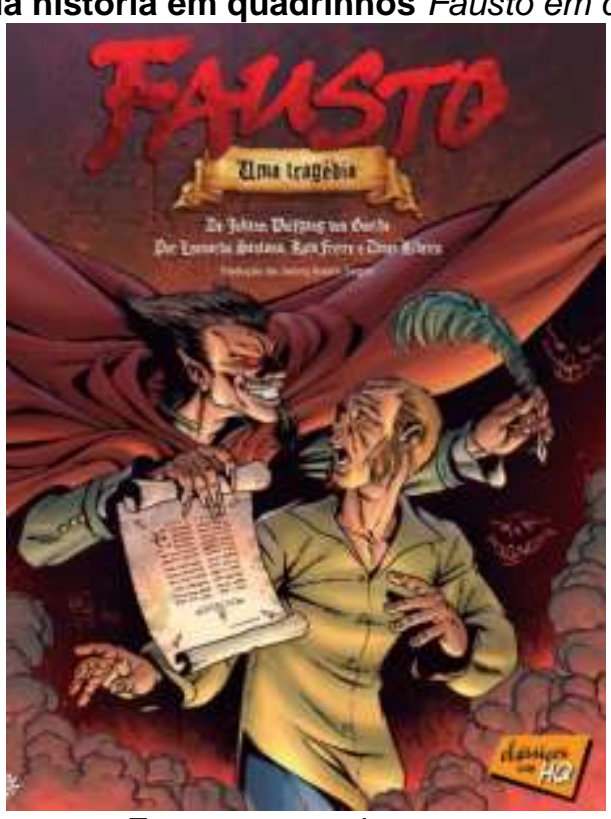

Fonte: acervo do autor.

Essa obra de literatura alemã foi realizada entre o final do século XVIII e início do século XIX e é considerada uma das principais produções literárias de todos os tempos, sendo redigida como uma peça de teatro, de forma poética. Fausto é o nome do protagonista dessa história e essa narrativa tem origem numa popular lenda alemã que trata de um pacto entre o demônio Mefistófeles e o médico (e alquimista) Fausto. Fica como observação que não existe um consenso do ano exato de nascimento do Fausto histórico, contudo, é possível afirmar que ocorreu na segunda metade do século XV.

Nessa adaptação literária brasileira para os quadrinhos (como também na obra original) são tratados de temas próprios do mundo medieval (como o tema da fé), além de questões relacionadas à sociedade contemporânea (como a problemática da urbanização). Entre os vários méritos da graphic novel Fausto em quadrinhos, podem ser exemplificados três: aprofundar diversas discussões filosóficas (como o tema da desilusão e, em especial, a desilusão em relação ao conhecimento); apresentar ao leitor as oscilações e transições 
entre um mundo "antigo" (feudal) e uma ordem social "nova" (capitalista), com o início da decadência moral burguesa e a formação de uma sociedade em que o dinheiro começa a mediar praticamente todas as relações políticas e sociais; além de realizar uma crítica social, sempre trabalhando com as figuras de linguagens, as imagens e os textos em conjunto, numa apropriação brasileira (e, portanto, latino-americana) desta obra.

Na Bolívia, segundo Cuevas [entre 2007 e 2018], após o evento da Revolución Obrera de 1952 (início do governo do Movimiento Nacionalista Revolucionario, que perdurou até 1964, período em que ocorreu a reforma agrária e a incorporação de amplas parcelas de diversos grupos sociais aos direitos políticos), apareceram revistas especializadas em humor político, que tiveram um curto período de duração. Esse autor cita as publicações: Alacrán, Alambre de Púas, Bombo, Cascabel, Chililín Campanillita, El Mosquito, Flechazos, Olla de Grillos, Pendx, Taca Taca e Thampulli.

Cuevas [entre 2007 e 2018] menciona como a mais importante a revista Cascabel - del humor politico, fundada em 1960 e que possuía uma linha de crítica social aos políticos daquele momento histórico, chegando a atingir cento e vinte e três números publicados. Cuevas [entre 2007 e 2018] também relaciona o golpe militar de 1971 com o fim dessa publicação, com o exílio político de muitos de seus colaboradores.

$\mathrm{Na}$ Venezuela, de acordo com o desenhista colombiano Diego Guerra (1997), destaca-se a revista intitulada El Sádio llustrado (1977-1978), que trabalhava com o humor político e a sátira e foi dirigida por Pedro Léon Zapata, considerado, ainda segundo Guerra (1997), como o mais importante caricaturista do país.

Lembra-se também do trabalho do desenhista Marcelo Avila, criador da série Estaciones, do gênero de aventuras. Outro quadrinista que merece ser lembrado é Rodolfo Ramirez, com uma produção de cunho mais niilista, do gênero da ficção-científica.

Na América Central, em específico na Nicarágua, tendo como referência o artigo de Berth (2017), sabe-se que, após a revolução Sandinista de julho de 
1979, os quadrinhos (e as caricaturas políticas) foram usados em campanhas educacionais de conscientização política. A partir desse momento, foram publicados livretos de histórias em quadrinhos, além do aparecimento constante dos quadrinhos nos jornais diários (como a Barricada) e nas publicações semanais (como El Tayacán e Semana cómica).

Esses quadrinhos tratavam de temas diversos, tais como: a defesa, a economia, as eleições e a infra-estrutura, incluindo também campanhas governamentais de esclarecimento da sociedade civil sobre o tema da saúde, incluindo a medicina preventiva e a nutrição, fazendo uso, inclusive, das metáforas visuais. Por exemplo: Somoza, o ditador deposto pelos socialistas, era retratado de forma desumanizada, representado nos quadrinhos como uma bactéria que possuía o seu rosto. Desse modo, eram tratados pelos quadrinhos questões como: por que as pessoas ficam doentes? Ou, dito de outro modo: qual a origem das enfermidades?

A educação com o uso de quadrinhos tornou-se na Nicarágua sandinista uma importante forma de comunicação que buscava a formação de um "novo homem", coletivista e solidário, em uma nova organização societária, de conformação socialista, constituindo também uma importante área da memória política da coletividade nicaraguense. Portanto, os quadrinhos tinham, nesse contexto, uma nítida função social de esclarecimento do povo nicaraguense, auxiliando na construção de uma nova realidade política e social, a de uma real democracia popular, com a participação efetiva das pessoas nos mais variados assuntos desse país, como os temas culturais, econômicos, políticos, sociais e trabalhistas, conformando, desse modo, uma "revolução cultural", com a consequente criação de uma nova identidade para a população, formada pela construção de novos valores e, a partir disso, novos comportamentos, mais cooperativos e menos egoístas.

Buscava-se, portanto, a transformação de uma realidade social, por meio de um processo de alteração das mentalidades e atitudes, fazendo uso de procedimentos didáticos diferenciados, tendo em vista os suportes de informação utilizados nesse ensino, criando novas oportunidades para a 
alfabetização e aprendizagem dos educandos, fornecendo, com isso, novas formas de relações ensino-aprendizagem que motivem os alunos.

Vallecillo (1984) lembra que, num sentido mais amplo, essas novas práticas educacionais também buscavam uma maior integração nacional, com base em um novo modelo econômico, evitando o enriquecimento exclusivo de apenas uma elite. Com isso, existia uma preocupação com o bem-estar da população nicaraguense, o que envolvia os mais diferentes aspectos da vida social, como a economia, a educação, a moradia, a reforma agrária, a saúde e o trabalho.

Esse uso intensivo das histórias em quadrinhos, para fins didáticos, também havia ocorrido em Cuba, após a Revolução Cubana, de 1959, o que causou uma alteração significativa do perfil da indústria quadrinística desse país, de acordo com Catalá-Carrasco (2017).

Berth (2017) também reforça tal fato, lembrando que essas campanhas educacionais realizadas pelo governo sandinista da Nicarágua foram influenciadas pelas práticas educacionais de Cuba, que ocorreram após a revolução socialista desse país, em 1959, incluindo o uso da educação política por meio dos quadrinhos. Inclusive, Zimmermann (2006) menciona a existência de mil voluntários cubanos que atuaram nas campanhas educacionais efetuadas pelo governo sandinista nicaraguense, num momento em que existiram trinta mil inscrições de voluntários cubanos dispostos a trabalhar na Nicarágua.

Em Cuba, Mogno (1997) menciona que ocorreu uma possibilidade de ampliação de mercado para as histórias em quadrinhos cubanas após o fato político da Revolução Cubana, em detrimento dos quadrinhos estadunidenses. Também menciona que a produção quadrinística cubana, mesmo antes da Revolução, já tinha publicações que trabalhavam com uma possível formação de uma nova sociedade e cita como exemplos "Julito 26" (de Santiago Armada, publicado em El Cubano Libre), "Loquito" (de René de la Nuez, publicado na Zig-Zag) e "Pucho" (de Virgilio Martínez Gaínza, publicado no suplemento Mella). 
Em artigo publicado na International Journal of Comic Art que trata sobre os quadrinhos cubanos entre os anos de 1959 e 1963, portanto, período após a tomada do poder por Fidel Castro, Someillan (2005) cita quatro publicações, entre jornais e revistas, que trabalham com narrativas visuais: Bohemia, Noticias de Hoy, Revolución e Verde Olivo. Os quadrinhos publicados nesses meios de comunicação auxiliaram na consolidação da Revolução Cubana e buscavam a formação de um "novo homem", de um novo sujeito histórico, possuidor de uma consciência socialista, num processo de transformação cultural e política nessa sociedade.

Essas narrativas reforçavam, por meio dos recursos próprios das histórias em quadrinhos, o desenvolvimento de novos comportamentos por parte da população cubana, trabalhando com uma simbologia mais próxima do "socialismo real". Era dada maior ênfase a uma educação voltada para uma reformulação da moralidade, expressa, por exemplo, pela temática da responsabilidade cívica e uma maior valorização do trabalho coletivo para a construção de uma nova sociedade, a qual deveria ter uma participação política ativa dos cidadãos. Tal prática é bem próximo do ideário presente no artigo "O Socialismo e o homem em Cuba", escrito em 1965, presente na coletânea Textos políticos, de Ernesto "Che" Guevara (2009), uma das principais lideranças da Revolução Cubana. De acordo com esse autor, quando se trata das práticas educativas nesse país:

Se exerce através do aparelho educativo do Estado de acordo com a cultura geral, técnica e ideológica, por meio de organismos como o Ministério da Educação e o aparelho de divulgação do partido. A educação se implanta nas massas e a nova atitude preconizada tende a converter-se em hábito; as massas vão tornando-a sua e pressionando aqueles que ainda não a têm [...].

Neste período de construção do socialismo, podemos ver o homem novo que vai nascendo. A sua imagem não está, contudo, acabada; não o poderia estar nunca, já que o processo avança paralelamente ao desenvolvimento de novas formas econômicas. [...]. O que importa é que os homens vão adquirindo cada dia maior consciência de necessidade de sua incorporação na sociedade e, ao mesmo tempo, de sua importância como motores desta. (GUEVARA, 2009, p. 64). 
Esse "novo homem" socialista poderia ser tanto um artista, um esportista, ou um intelectual, mas em todos esses casos os quadrinhos valorizavam a atividade política dos atores sociais, sendo essa realizada em organizações de orientação socialista.

Desse modo, verifica-se que o governo cubano, naquele momento histórico, fez uso das histórias em quadrinhos, como um meio de comunicação de massa, para a conscientização política e social da população cubana.

Na América do Norte, em específico no México, país de importante tradição quadrinística, é lembrado por Soto Díaz [entre 2008 e 2018] que a sua produção de quadrinhos influenciou de modo significativo o mercado quadrinístico nos países de língua espanhola, em especial nas décadas de 1960 e 1970.

Em relação às histórias em quadrinhos políticas, o trabalho mais importante é o do caricaturista e quadrinista Rius (Eduardo Humberto del Río Garcia). Soto Díaz [entre 2008 e 2018] menciona que Rius colaborou com um número expressivo de diários mexicanos, por meio da realização de caricaturas, tratando de diferentes temas, como a crítica ao fascismo, os desaparecidos políticos, o movimento estudantil, as problemáticas da educação, o sandinismo na Nicarágua e o sindicalismo mexicano, numa luta pela defesa da liberdade de expressão. Ao todo, Rius contribuiu em mais de cem publicações, ao longo de sua vida.

Fernández L'Hoeste e Poblete (2009) lembram que a produção artística de Rius contempla um número significativo de obras que tratam de noções relacionadas ao pensamento do socialismo científico e, consequentemente, das classes sociais.

Bona e Giuffrida (1997) ressaltam duas das principais histórias em quadrinhos de Rius: Los supermachos e Los agachados. O próprio Del Río Garcia (1984) menciona que os quadrinhos Los supermachos tiveram início em 1965, para um público adulto, sendo uma publicação que envolve conteúdos educativos, a crítica política e a sátira. Um fato digno de nota é o de que a 
publicação Los Supermachos chegou a receber uma premiação no Congresso Mundial de Comics na cidade italiana de Milão.

Fossati e Rosso (1997), também se referem ao trabalho de Rius, tendo em vista a sua produção quadrinística, como possuidor de uma das contribuições mais relevantes no panorama satírico mexicano. Inclusive, Bartra (2009) relata que seu trabalho quadrinístico teve "discípulos", como Javier Cavo Torres e Miguel Ángel Gallo. As figuras vinte e quatro e vinte e cinco apresentam exemplos do trabalho de Rius.

Fig. 24 - Crítica social apresentada na obra de Rius.

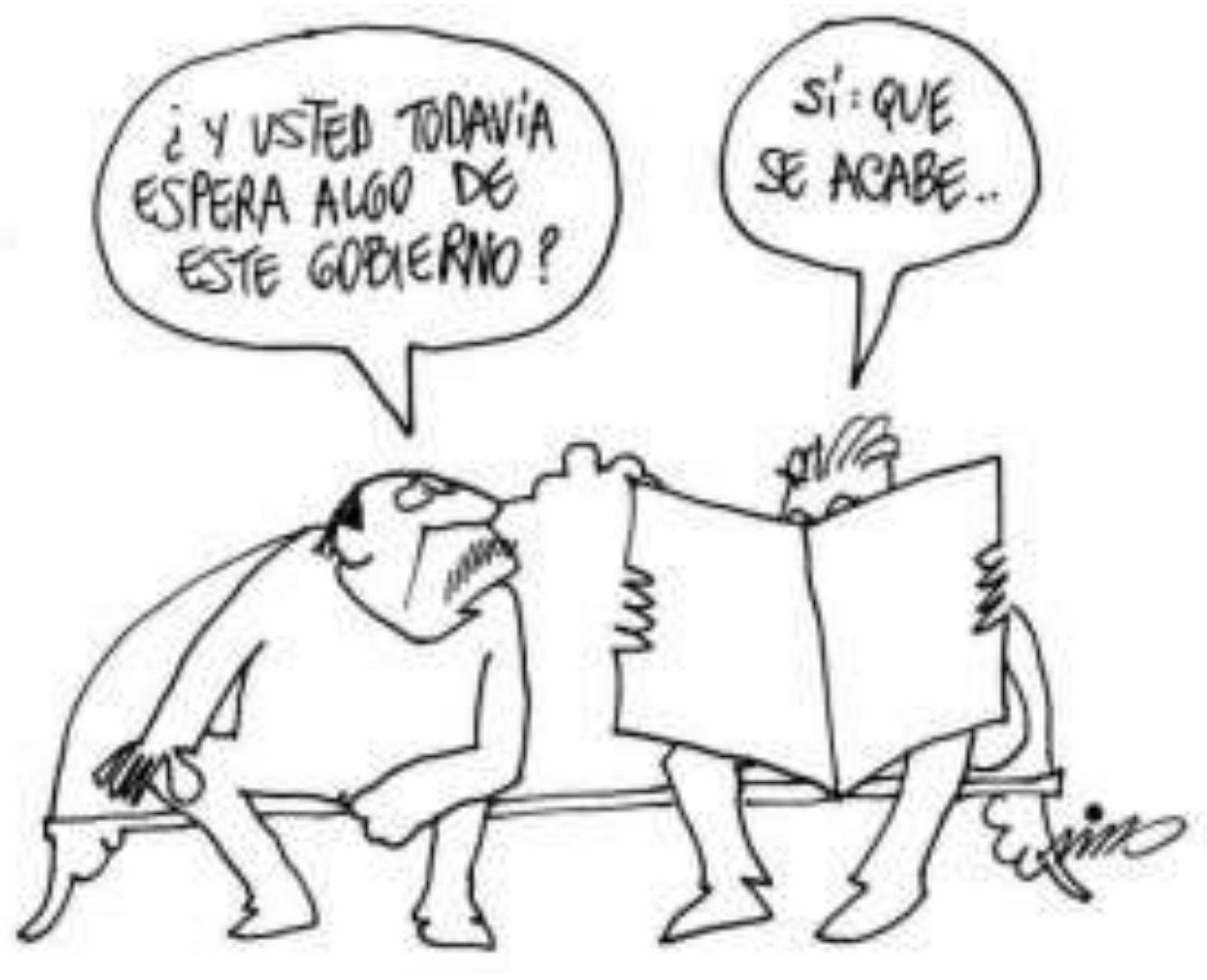

Fonte: Latino Weekly Review. Disponível em:

<latinoweeklyreview.com/?attachment_id=292726>. Acesso em: 28 nov. 2018. 
Fig. 25 - Um outro exemplo do trabalho artístico de Rius.

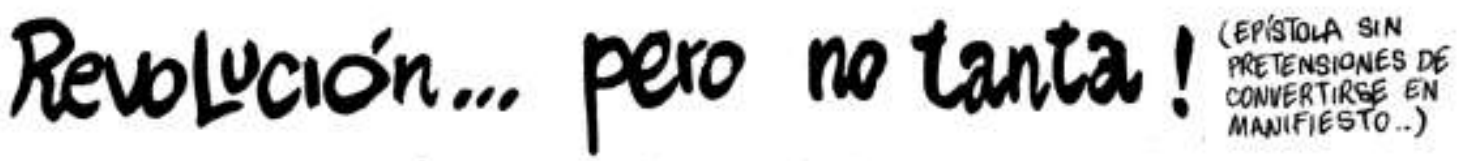

LA REVOLUCÓN MEXICANA PUEDE CONSIDERARSE LA UNICA EN EL MUNDO QUE AVANZA CON UN SOLO PIE... PORQUE :

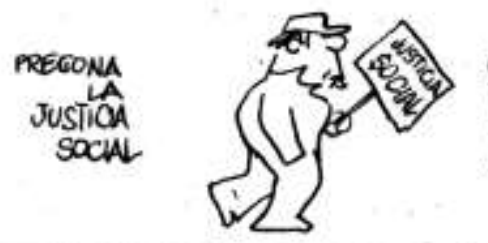

EN UN RAIS DONDE TODO EL MUNDO LE TIENE FÁNICO A LA POLICIA...
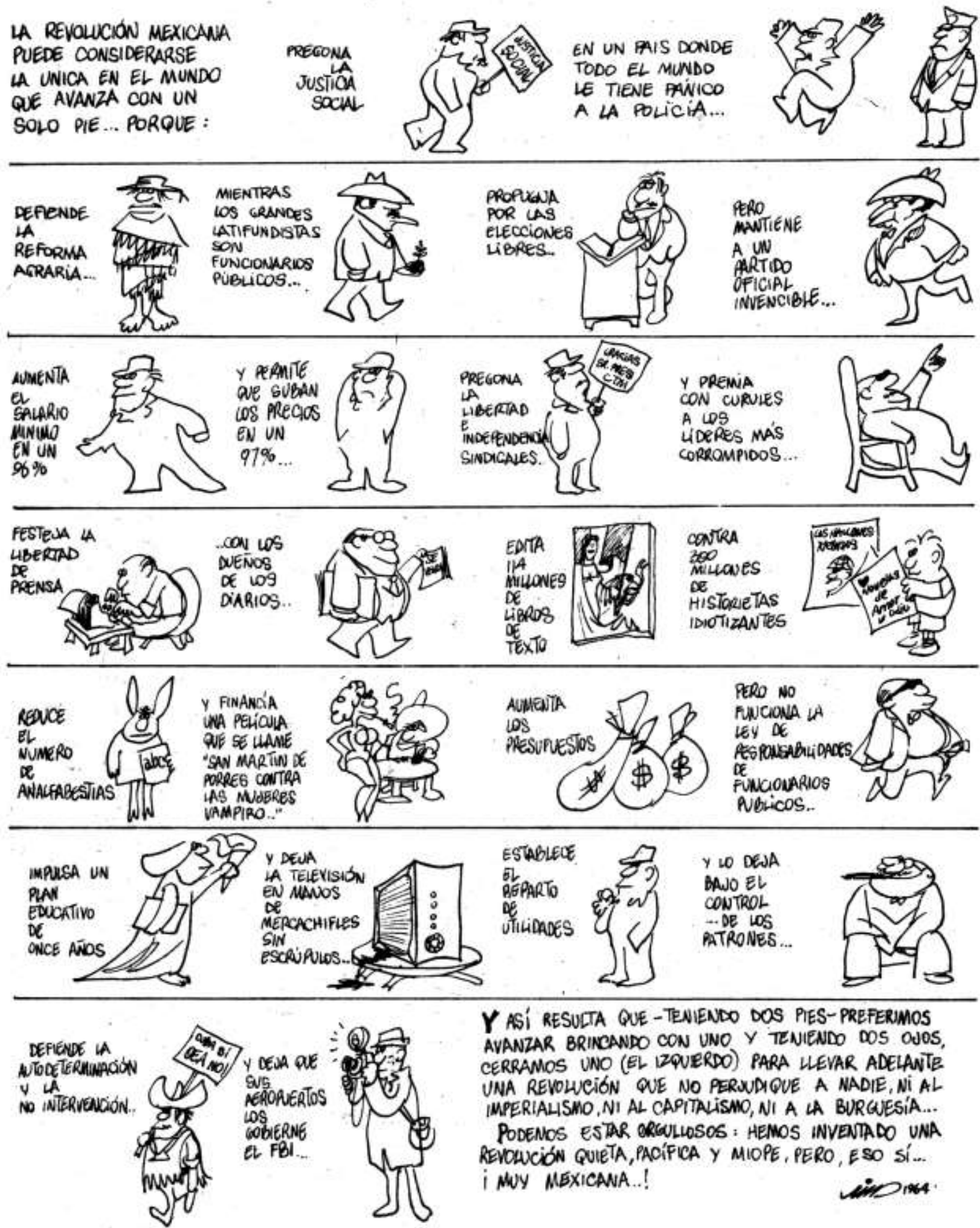

$Y$ ASI RESULTA QUE-TENIENDO DOS PIES-PREFERMMOS ayanzar brincando cON UNO Y TENIENDO DOS OJOS, CERRAMOS UNO (EL IZQUERDO) PARA LLEVAR ADELANTE UNA REVOLUCIÓN QUE NO PERUUDIQUE A NADIE, NI AL IMPERIALISMO, NI AL CAPITALISMO, NI A LA BURGUESÍA...

PODENOS ESTAR ORGULLOSOS: HEMOS INVENTADO UNA REVOUUCIÓN QUIETA, PACÍFICA Y MIOPE, PERO, ESO SÍ... i MUY MEXICANA.!!

Fonte: acervo do orientador desta tese. 


\section{HÉCTOR GERMÁN OESTERHELD E A SUA INOVADORA PRODUÇÃO QUADRINÍSTICA}

O roteirista Héctor Germán Oesterheld nasceu em 23 de julho de 1919, na cidade de Buenos Aires e, de acordo com Montero (2013), é reconhecido como o roteirista mais importante da história da produção quadrinista argentina e da América Latina, além de ser um dos principais nomes do meio quadrinístico mundial.

Oesterheld fez uso de sua capacidade imaginativa para a criação de várias histórias em quadrinhos que, num primeiro momento, pertenciam, sobretudo, aos gêneros da aventura e da ficção científica e, posteriormente, em função do cenário cultural e social no qual trabalhou, envolveu-se fortemente com a temática da política, que ficou onipresente em sua produção quadrinística.

Ele também criou uma quantidade significativa de personagens em suas histórias (ao todo, mais de cem), tratando-os com significativa profundidade psicológica, ao fazer uso, em seus roteiros, tanto das reações humanas como também dos sentimentos individuais. Por outro lado, de modo inovador, tratou dos grupos sociais, em seus quadrinhos, dando ênfase, por exemplo, às relações societárias que envolviam o companheirismo e a solidariedade, fugindo do individualismo comumente praticado por muitos heróis e superheróis.

Uma das contribuições mais significativas das histórias em quadrinhos oesterheldianas foi ter renovado o gênero da ficção científica nos quadrinhos, pois sua produção trabalha fortemente com o imaginário do leitor, ao mesmo tempo em que provoca uma sensação de insegurança, ao transmitir uma visão de mundo que envolve angústia e pessimismo. De todas as suas obras, a mais importante e reconhecida (tanto na Argentina, como na América Latina, e em vários outros países) é El Eternauta.

Em relação a sua formação acadêmica, de acordo com o livro Oesterheld en tercera persona (2008), esse roteirista de quadrinhos obteve a graduação 
em Ciencias Naturales (com especialização em Geologia). Com isso, teve a oportunidade de trabalhar na Dirección Nacional de Minas, no laboratorio de minería del Banco Industrial de la Republica Argentina e também no Banco Nacional de Desarollo.

De acordo com Montero (2013), Oesterheld iniciou sua carreira de escritor com a publicação de "Truila y Miltar", na seção literária do jornal La prensa, na data de 3 de janeiro de 1943. Trata-se de um conto infantil, com fim educativo, que trata do tema da solidariedade. Escreveu, ao longo da sua vida, vários outros contos infantis e histórias de ficção científica, além das histórias em quadrinhos.

Também no Brasil foram publicados contos infantis de Oesterheld, por meio da coleção Reino Encantado, da editora Melhoramentos, como: "O Galinho Valente" e "Doutor Ratinho", além de "O Coelhinho Preguiçoso", este último publicado com o pseudônimo de Héctor Sanchez Puyol. Também infantil, foi aqui publicada a história intitulada Eram três amigos, pela editora Martins Fontes.

Segundo o livro Oesterheld en tercera persona (2008), a primeira história em quadrinhos que contou com roteiro de Oesterheld foi "Cargamento Negro", com desenhos de Eugenio Zoppi, publicada na revista Cinemisterio, da editora Abril, em seu número cinquenta e um, na data de 31 de outubro de 1951. Contudo, essa mesma publicação ressalta que, em termos de publicação, sua primeira história em quadrinhos foi "Ray Kitt", com desenhos de Hugo Pratt, também na revista Cinemisterio, em seu número trinta e três, na data de 16 de maio de 1951, sendo essa última, portanto, iniciada posteriormente aos quadrinhos "Cargamento Negro".

Gociol (2007) lembra que, na data de $1^{\circ}$ de fevereiro de 1952, teve início a publicação, na revista Misterix, da editora Abril, em seu número cento e setenta e seis, a história em quadrinhos "Bull Rockett", dos gêneros de aventura e ficção científica, com roteiro de Oesterheld. Essa série teve, de acordo com Avila (2007), diferentes desenhistas, como Paul Campani, Solano López, Julio Schiaffino, Angel Alberto Fernández. 
Segundo Gociol e Rosemberg (2003), nessa mesma revista Misterix, em seu número duzentos e vinte e dois, a partir de 9 de janeiro de 1953, teve início a publicação, de modo seriado, da história em quadrinhos "Sargento Kirk". Com roteiros de Oesterheld e desenhos de Hugo Pratt, essa publicação pertencente ao gênero western, expõe ao leitor a presença de um protagonismo coletivo (um grupo heterogêneo de pessoas, unido por valores como a amizade), a crítica ao mundo atual e um desconforto em relação aos problemas sociais passíveis de serem resolvidos.

Essa história em quadrinhos trata de uma aventura, com a presença de índios, em território norte-americano. O protagonista da história, Sargento Kirk, é um militar que já no primeiro episódio deserda em função de problemas com a sua consciência, tendo em vista a brutalidade com que eram tratados os nativos pelos militares, pois Sargento Kirk tem uma mentalidade pacifista.

Posteriormente, ele organiza um novo agrupamento, tendo esse coletivo um novo protagonismo, alheios à dicotomia índios versus soldados, no qual é valorizada a amizade e a fraternidade, com cada personagem cumprindo um diferente papel social neste grupo. Essa história em quadrinhos também contou com desenhos de Jorge Moliterni, Horacio Porreca, Gisela Dester e, por fim, Gustavo Trigo. A figura vinte e seis apresenta o personagem Sargento Kirk.

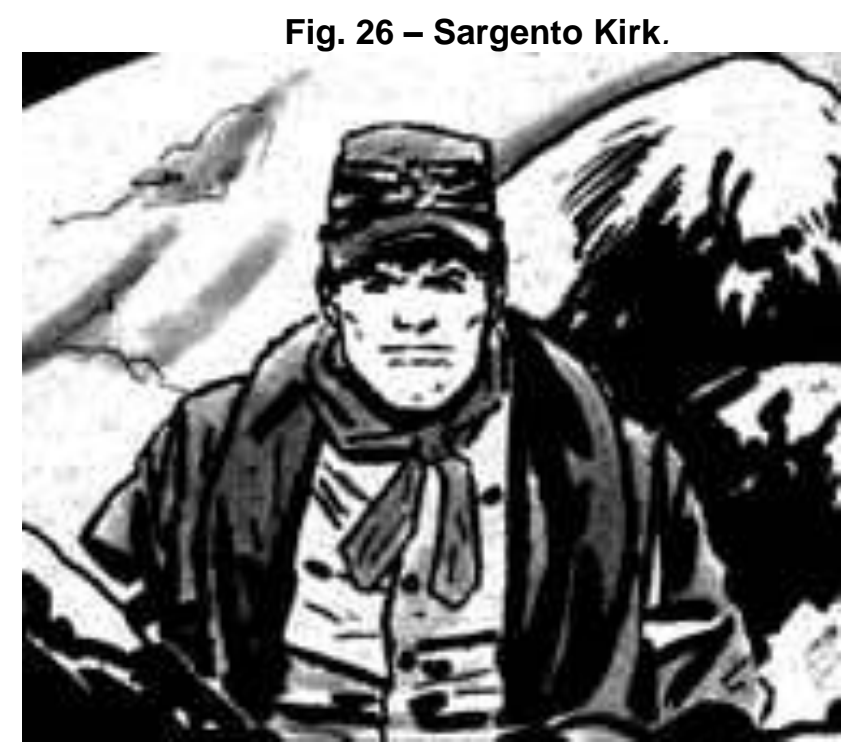

Fonte: Historieteca. Historieta argentina. Disponível em: <historieteca.com.ar/HGO/hgo.htm>. Acesso em: 20 nov. 2018. 
Outras histórias em quadrinhos de Oesterheld que tratam da temática indígena são: "Watami" (publicada em 1962, em parceria com Jorge Moliterni, por meio da revista Misterix), e "Wakantanka" (em 1976, em parceria com Juan Zanotto, por meio da publicação Tit Bits). É importante lembrar que durante o período em que Oesterheld escrevia os roteiros de Wakantanka, foi sequestrado pelas forças militares; com isso, a continuação dessa história foi realizada por Carlos Albiac.

Montero (2013) menciona que, entre 1953 e 1957, uma publicação de ficção científica da editora Abril, que tratava de temas da época, incluindo a problemática da questão nuclear e o iminente contato com seres extraterrestres, recebeu contribuições de Oesterheld: Más allá de la ciencia y la fantasia. Por vezes, para esta publicação, Oesterheld teve a oportunidade de traduzir textos de Isaac Asimov, Philip Dick e Ray Bradbury. Gociol (2007) ressalta que Oesterheld falava e sabia ler em alemão, espanhol, francês e inglês.

Ainda segundo Montero (2013), por meio dessa publicação da editora Abril, foi possível a Oesterheld escrever alguns contos, inclusive tratando de temas futuristas. São exemplos: "Inocente Maquiavelo reforzado" e "Cuidado com el perro". Essa revista teve um total de quarenta e oito edições e foi finalizada pela editora num momento em que as vendas ocorriam de modo considerável, há poucos meses do lançamento do primeiro satélite terrestre em direção ao espaço - o soviético Sputnik, num momento de crescente interesse por temáticas ligadas ao tema da ficção científica. Gago (2010) considera que Más allá de la ciencia y la fantasia era a mais importante revista de ficção científica em território argentino, durante a década de 1950.

Em relação às histórias em quadrinhos do gênero da ficção científica, durante a década de 1950, Gociol e Rosemberg (2003) lembram dos quadrinhos "Uma-Uma”, que possuía roteiros de Oesterterheld e desenhos de Francisco Solano López, publicada em Rayo Rojo, em 1955. Essa narrativa já trazia a temática da invasão extraterrestre, que Oesterheld iria desenvolver, posteriormente, em El Eternauta. 
De acordo com Montero (2013), Oesterheld fundou a Editora Frontera e foi responsável, nesta editora, pela publicação das revistas Frontera e Hora Cero, cujos primeiros números foram publicados no ano de 1957.

O primeiro número da revista Frontera continha as histórias de "Tipp Kenya" (ilustrações de Carlos Roumé), "Joe Zonda" (desenhos de Francisco Solano López), "Verdugo Ranch" (desenhos de Ivo Pavone) e "Ticonderoga" (desenhos de Hugo Pratt). Todos os roteiros dessas histórias em quadrinhos foram feitos por Oesterheld. O mercado dessa revista buscava leitores de histórias de aventuras, como o do gênero western.

A revista Hora Cero, em seu primeiro número, apresentava ao leitor as seguintes histórias em quadrinhos: o primeiro capítulo de "Rolo, el marciano adoptivo" (desenhos de Francisco Solano López); "Ernie Pike" (desenhos de Hugo Pratt); "Lucky Piedras" (desenhos de Carlos Cruz) e "El Héroe" (desenhos de Solano López). Novamente, todos os roteiros desses quadrinhos foram feitos por Oesterheld. Contudo, o foco de mercado dessa revista de história em quadrinhos era diferente da revista Frontera, pois Hora Cero tinha como público os leitores dos gêneros de histórias bélicas e ficção científica.

Uma das histórias publicadas pela revista Hora Cero, "Rolo, el marciano adoptivo", num certo sentido, antecipa a história em quadrinhos El Eternauta, em função das suas várias semelhanças: os dois quadrinhos pertencem ao gênero da ficção científica; tratam das relações entre extraterrestres e seres humanos; têm a narrativa ambientada, sobretudo, na cidade de Buenos Aires; trabalham com a ideia do protagonismo coletivo; possuem alguns personagens movidos por um profundo humanismo, além de ambas possuírem como um dos protagonistas da história um professor que possui interesse significativo em temáticas científicas.

Até mesmo, em alguns momentos, o vestuário dos personagens se assemelha, no caso de "Rolo, el marciano adoptivo", com os trajes espaciais e, em El Eternauta, com os trajes isolantes.

Contudo, a série "Rolo, el marciano adoptivo", é uma história em quadrinhos que não possui o mesmo patamar de desenvolvimento, em termos 
de desenhos, narrativas e problematizações sociais que El Eternauta. Além disso, possui diálogos extensos, fazendo com que, por vezes, as imagens fiquem num plano secundário.

O personagem principal dessa história é um professor, chamado Rolo Montes, que vive em uma pensão, frequenta uma associação esportiva e, em conjunto com alguns amigos, torna-se um foco de resistência aos planos dos extraterrestres (nessa história chamados de pargas) que buscavam sequestrar os alunos do Rolo Montes, para levá-los para fora do planeta Terra, com o objetivo de fazer experimentos científicos. Na edição da editora argentina La Página, de 2009, a história em quadrinhos Rolo, el marciano adoptivo possui noventa e seis páginas, em preto-e-branco.

As histórias em quadrinhos de "Ernie Pike" têm como personagem principal um correspondente de guerra de mesmo nome, que trata de temas trabalhados ao longo de toda a produção de Oesterheld, como a amizade, a fragilidade humana, o sacrifício e a solidariedade - neste caso, num contexto de guerra. Essa história em quadrinhos faz uso constante da técnica do flashback para a narração da história e, em linhas gerais, não possuem os tradicionais finais felizes das histórias em quadrinhos de entretenimento.

Em "Ernie Pike", Oesterheld expõe ao leitor a inutilidade das guerras e indica que esse é sempre um fato lamentável para toda a humanidade. Com isso, o autor argentino instiga o leitor a uma reflexão moral sobre os reais e verdadeiros valores da humanidade, como o direito à liberdade e à própria vida; ele faz isso, por exemplo, por meio do relato da esperança de alguns personagens por um auxílio (ou mesmo da sobrevivência), que nunca chega.

O protagonista, que fornece o nome para os quadrinhos "Ernie Pike" foi inspirado no jornalista e correspondente de guerra estadunidense Ernie Pyle. Após Hugo Pratt, vários outros desenhistas também desenharam Ernie Pike, como Daniel Haupt, Estévez, Eugenio Colonnese, Francisco Solano López, Horacio Porreca, Jorge Moliterni, José Muñoz, Julio Schiaffino, Leandro Sesarego, Leopoldo Durañona, Mario Bertolini e Néstor Olivera. 
Na revista Hora Cero, em seu número vinte e nove, no final dos anos 1950, também apareceu o personagem Buster Pike (um "irmão" de Ernie Pike). Buster Pike foi desenhado por Julio Schiaffino e, como seu "irmão", também é jornalista. Contudo, Buster Pike trabalha com as notas policiais.

De acordo com Gociol e Rosemberg (2003), o personagem Ernie Pike também informou aos leitores as primeiras notícias de outro personagem criado por Oesterheld e Hugo Pratt: Lord Crack, na publicação Hora Cero Semanal, em 1958. A partir do número sessenta e um desta revista, Ernie Pike deixa de relatar notícias acerca do personagem Lord Crack, que se torna um protagonista de suas próprias histórias em quadrinhos. Posteriormente, os quadrinhos de Lord Crack tiveram desenhos de Jorge Moliterni, Mario Bertolini e Flores.

Oesterheld, em parceria com Solano López, também criou outra história em quadrinhos bélica, chamada "Amapola Negra", série que saiu entre os anos 1958 e 1959, na revista Hora Cero Mensual. Nesses quadrinhos, Amapola Negra é um bombardeiro inglês que tem como alvo os alemães. Também nessa história em quadrinhos, Oesterheld trata de temas como a amizade e a solidariedade entre os seres humanos, além de temas relacionados à guerra, como o pânico social.

Entre os anos de 1958 e 1959 ocorreu, pela primeira vez, a publicação da história em quadrinhos "Sherlock Time", uma das principais obras do roteirista Oesterheld, por meio das revistas Hora Cero Extra e Hora Cero Semanal, ambas da editora Frontera, em uma série de onze capítulos. Essa obra do gênero de ficção científica contou com desenhos de Alberto Breccia, um artista plástico que trabalhava com quadrinhos, o qual fez uso sistemático de experimentos que envolvem uma combinação do uso, num mesmo quadrinho, do contraste entre luzes e sombras.

"Sherlock Time" marca o início de um vínculo profissional entre Oesterheld e Alberto Breccia. Essa dupla de quadrinistas trabalhou, novamente, em outras obras, podendo ser mencionadas, como exemplos: "Mort Cinder", uma biografia de Ernesto "Che" Guevara e uma nova versão de El Eternauta. 
Posteriormente, a história em quadrinhos Sherlock Time foi publicada, na Argentina, na coleção Nueva Biblioteca Clarín de la Historieta, em seu número sete, no ano de 2006, num volume de duzentas e oitenta e oito páginas, em preto-e-branco, apresentando os seguintes capítulos: Hora Cero Extra (do número 5 até o 8), Hora Cero Semanal (do número 86 ao 88), Hora Cero Extra (número 9), Hora Cero Semanal (do número 89 ao 104), Hora Cero Extra (do número 10 ao 13). Essa publicação também apresenta ao leitor dois artigos introdutórios, de Roberto Fontanarrosa e Diego Accorsi, além de um perfil de Oesterheld e Alberto Breccia.

Sherlock Time ocorre em uma residência conhecida como "La Tumba", pois todos os seus proprietários desapareceram e que foi adquirida pelo personagem Julio Luna, um senhor aposentado - é digno de nota o fato de que a figura de Julio Luna era a imagem do próprio Alberto Breccia no momento em que esse artista plástico desenhava esta história.

Essa casa, chamada "La Tumba", possui uma torre que é uma cosmonave (nave espacial), utilizada por seres extraterrestres para levar terráqueos para outro planeta, com o objetivo de estudá-los. Tal fato é descoberto pelo protagonista da história, o detetive Sherlock Time, que já é apresentado ao leitor ao longo da primeira aventura da séria (Hora Cero Extra, em seu número 5). Tanto Julio Luna como Sherlock Time passam, a partir desse momento, por várias aventuras ao longo desta história. Algumas das principais temáticas tratadas nessa história em quadrinhos são: a ganância, a justiça e a lei. A figura vinte e sete mostra os dois principais personagens desses quadrinhos (Sherlock Time, à esquerda e Julio Luna, à direita). 
Fig. 27 - Os personagens Sherlock Time e Julio Luna, respectivamente.

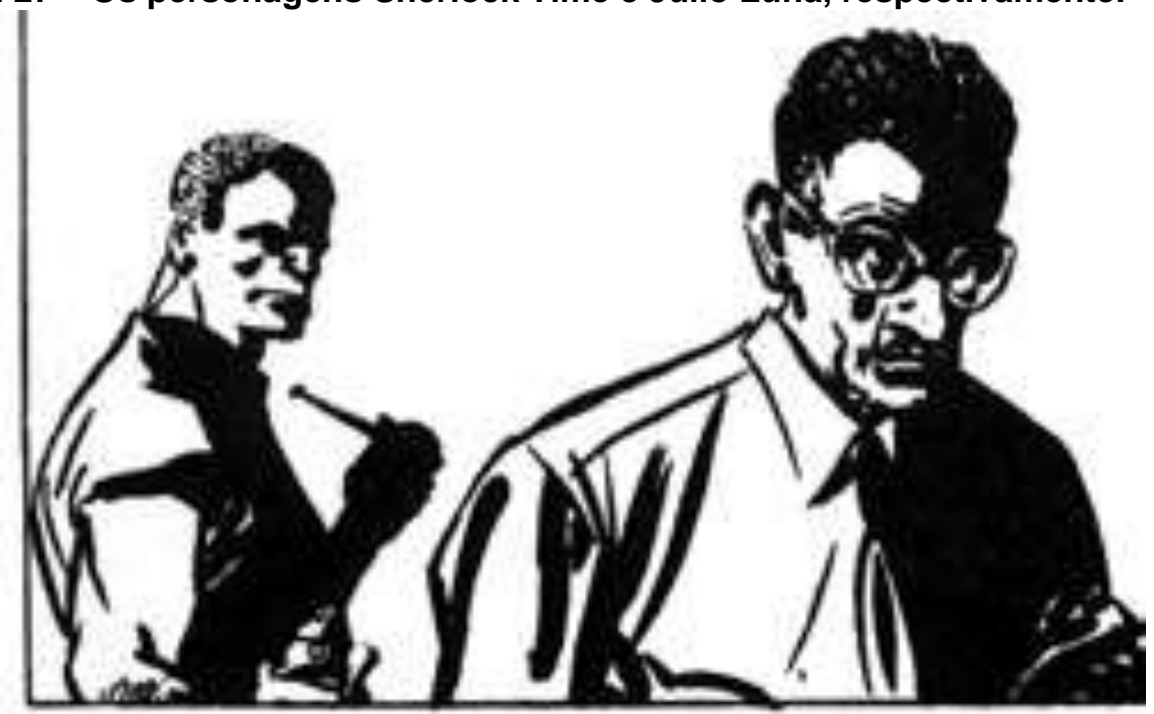

Fonte: Historieteca. Historieta argentina. Disponível em: <historieteca.com.ar/HGO/hgo.htm>. Acesso em: 20 nov. 2018.

Posteriormente, em 1961, de acordo com Montero (2013), os direitos sobre as revistas Frontera e Hora Cero foram cedidas por Oesterheld para a editora Emilio Ramírez, em função de problemas administrativos e econômicos pelos quais a Editora Frontera passava. Tal fato afetou a relação profissional entre Oesterheld e os desenhista que colaboravam com seu trabalho. Ainda segundo Montero (2013), o desenhista Hugo Pratt era especialmente crítico ao modo como Oesterheld dirigia a Editora Frontera, como, por exemplo, pelo fato de não selecionar adequadamente os desenhistas para suas histórias. Com o fim da editora Frontera, Oesterheld passou a trabalhar como empregado para a editora Emilio Ramírez.

Entre 1962 e 1964, por meio das publicações Misterix e Super Misterix, Oesterheld, novamente em parceria com o desenhista Alberto Breccia, realizou uma de suas principais obras: as histórias em quadrinhos "Mort Cinder". Esses quadrinhos pertencem tanto aos gêneros da fantasia, como também do histórico, além da ficção científica. Em função da qualidade desses quadrinhos, também foram feitas edições em outros países, como a Espanha, a França e a Itália.

É adequado ressaltar que provavelmente a narrativa de Oesterheld nesses quadrinhos pode ter sido influenciada pelo conto El Inmortal, de Jorge Luis Borges, um dos principais nomes da literatura argentina. Esse último texto, 
publicado em 1949, trata do tema da imortalidade do ser humano e também do deslocamento pelo espaço-tempo (vale lembrar que Borges, Alberto Breccia e Oesterheld viviam sob a mesma atmosfera cultural e intelectual da Argentina, naquele momento histórico). Além disso, "Mort Cinder" também é tributário outra história em quadrinhos realizada anteriormente por Oesterheld e Alberto Breccia: "Sherlock Time", já anteriormente mencionada nesta tese. Nesse sentido, um exemplo significativo encontra-se na segunda aventura de "Sherlock Time" (publicada no número seis da revista Hora Cero Extra), aparece um personagem com feições de idoso que trabalha com antiguidades, ou seja, um antecessor do antiquário Ezra Winston (coprotagonista de "Mort Cinder"). Em "Sherlock Time" seu nome é Eustaquio Méndez.

A história em quadrinhos Mort Cinder foi publicada, novamente, na Argentina, no número treze da coleção Biblioteca Clarín de la Historieta, no ano de 2004, num volume de duzentas e cinquenta e oito páginas, em preto-ebranco, apresentando dez capítulos: "Ezra Winston, el anticuario", "Los ojos de plomo", "La madre de Charlie", "La torre de Babel”, "En la penitenciaría: Marlin", "En la penitenciaría: El Frate", "El vitral”, "La nave negrera”, "La tumba de Lisis", "La batalla de las Termópilas", além de um apêndice.

Além desses capítulos citados no parágrafo acima, consta também um prólogo intitulado "El pasado que vuelve", escrito por Guillermo Saccomanno (2004), e uma introdução chamada "Un poco de historia", de autoria de Pablo Muñoz (2004). Menciona-se que Oesterheld teria dito acerca da história em quadrinhos "Mort Cinder": "[...] Mort Cinder é a morte que não termina de sêlo. Um herói que morre e que ressucita. Em Mort Cinder há angústia, tortura [...]". (MUÑOZ, Pablo, 2004, p. 14, tradução nossa) ${ }^{10}$.

O protagonista dessa história em quadrinhos é Mort Cinder, um personagem ressucitado que retoma episódios por ele vividos, em distintas épocas e em diferentes locais, no qual age e faz reflexões históricas. Com isso, é possível mencionar que o protagonista desses quadrinhos tem a capacidade de deslocar-se no espaço-tempo. As temáticas principais desses quadrinhos

${ }^{10}[\ldots]$ Mort Cinder es la muerte que no termina de serlo. Um heróe que muere y que resucita. En Mort Cinder hay angustia, tortura [...]. 
são: a reencarnação, a construção da memória, a dominação (e a manipulação) política e, também, a história social.

O coprotagonista dessa história em quadrinhos, como já mencionado anteriormente, é o antiquário Ezra Winston. É digno de nota que Alberto Breccia desenhou esse personagem a partir de sua própria imagem envelhecida.

Nessa história em quadrinhos, Ezra Winston, em seu negócio, ou empreendimento, depara-se com objetos antigos, os quais determinam o percurso das suas aventuras, nas quais desenrolam-se tramas que transcendem as noções de espaço e tempo. A narrativa é ambientada em uma atmosfera noturna, possuindo, um tom sóbrio, com o uso predominante, ao longo das páginas, do claro-escuro. A figura vinte e oito apresenta, à esquerda, o personagem Ezra Winston e à direita, Mort Cinder.

Fig. 28 - Os personagens Ezra Winston e Mort Cinder, respectivamente.

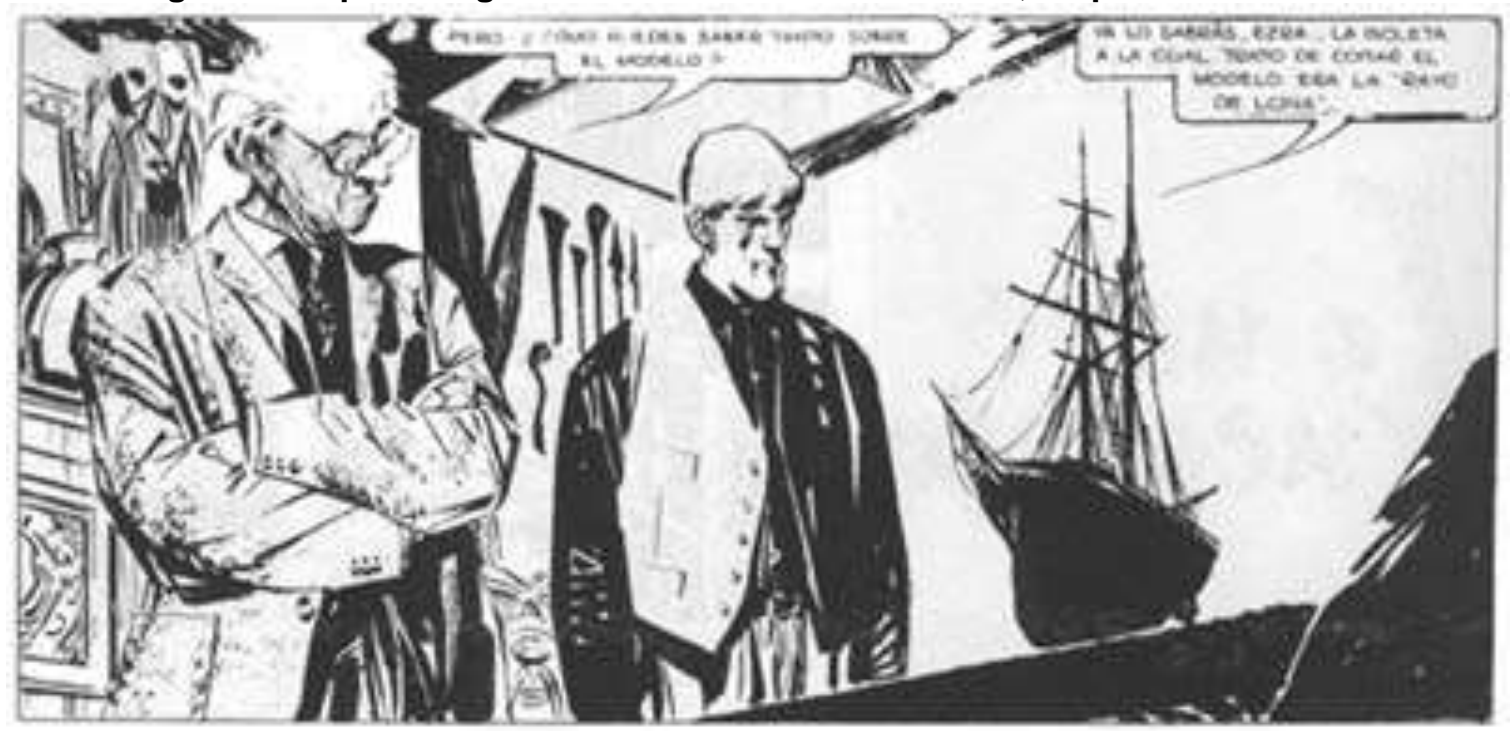

Fonte: Historieteca. Historieta argentina. Disponível em: <historieteca.com.ar/HGO/hgo.htm>. Acesso em: 20 nov. 2018.

Tendo como referência o volume pertencente à coleção Biblioteca Clarín de la Historieta: no capítulo "Ezra Winston, el anticuario" (Ezra Winston, o antiquário), publicado em um primeiro momento em Super Misterix, em agosto de 1962, é apresentado ao leitor o (erudito) antiquário Ezra Winston, que trabalha com a negociação de mercadorias antigas, além de colecionar, 
analisar e, também, catalogar esses objetos. Nessa história Ezra Winston está negociando artigos do antigo Egito. Esse capítulo é o único que não aparece o personagem Mort Cinder.

Esses quadrinhos possuem um fundo filosófico, trabalhando com o questionamento e a reflexão do leitor, incluindo a temática da origem dos fatos sociais. A última frase desse capítulo, dita por Ezra Winston, é "Está el pasado tan muerto como creemos?".

O próximo capítulo é intitulado "Los ojos de plomo" (Olhos de chumbo), publicado primeiramente na revista Misterix, entre julho e dezembro de 1962, e é a história mais extensa de todas. Pertencendo ao gênero da ficção científica, esses quadrinhos trabalham com a questão do tempo (passado, presente e futuro); o controle mental de uma pessoa sobre outras, o que envolve, por exemplo, a anulação de personalidades; além de planos de dominação global (por parte do professor Angus). Nesse capítulo também é apresentado ao leitor o personagem Esqueleto, um dos principais fornecedores de mercadorias antigas para Ezra Winston.

Também pela primeira vez aparece ao leitor o personagem Mort Cinder, "retornando" à vida após sair de um túmulo no cemitério de Mertonville, pois Mort Cinder é um homem eterno, um imortal, na verdade, um viajante do tempo, ao longo de sucessivas reencarnações. Esse encontro entre Mort Cinder e Ezra Winston marca o início de várias aventuras, ao longo dos séculos, com esses dois personagens.

Entre os demais capítulos, a título de exemplo, menciona-se "El vitral" (O Vitral), publicado primeiramente na revista Misterix, em maio de 1963. Esses quadrinhos pertencem ao gênero histórico e narra a venda de um vitral para o antiquário Ezra Winston. Quando banhado pela luz que irradiava esse vitral, Ezra Winston recordava ritos com sacrifícios humanos, ocorridos no contexto histórico da conquista dos espanhóis em território inca, situado atualmente no Peru, no qual ele tentava acertar um homem com um punhal: essa pessoa era Mort Cinder. A figura vinte e nove apresenta a primeira página da história, com o vitral, na segunda tira. 
Fig. 29 - O personagem Ezra Winston analisando o vitral.
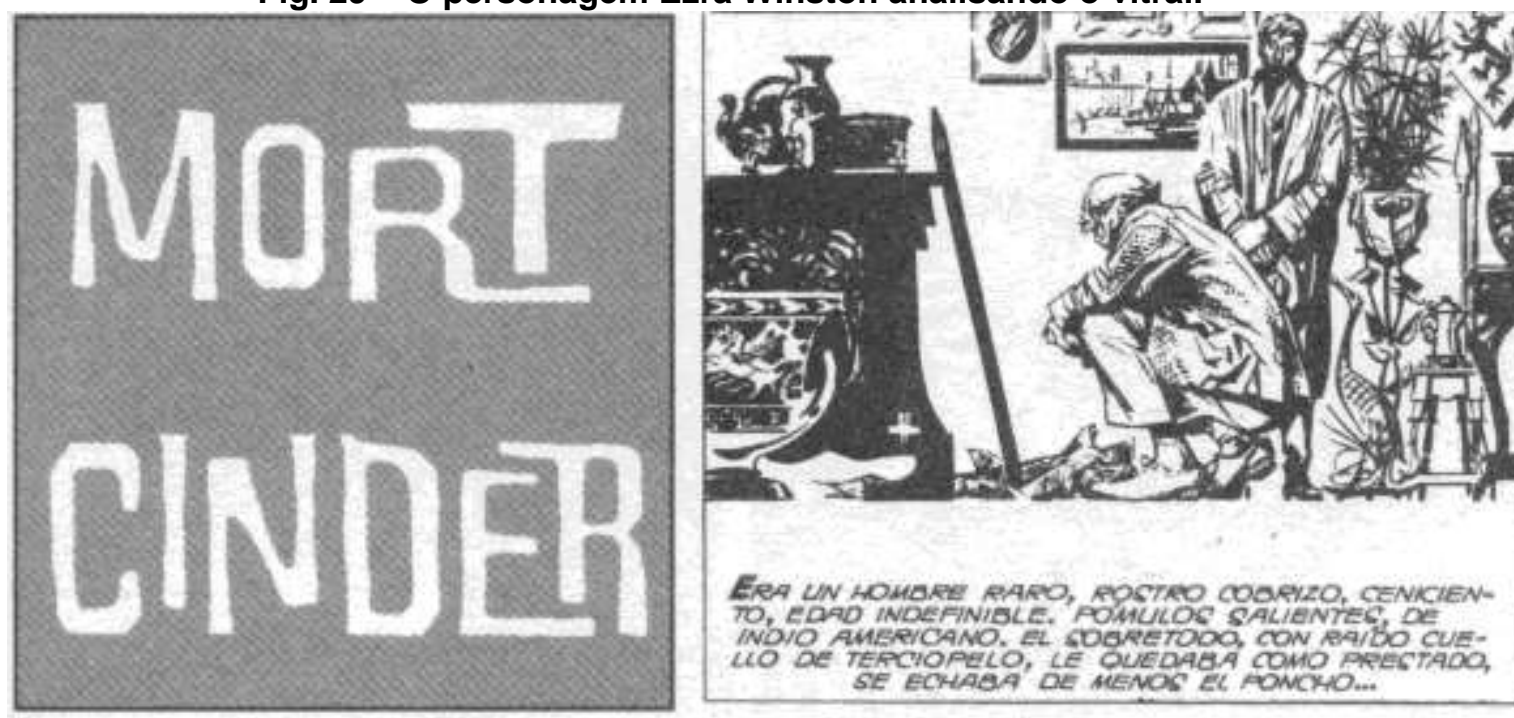

ERA UN HOMARE RARO, ROGTRO COARZO, CENICIENTO, EDAD INDEFINIBLE. "AOWULOS SALIENTES DE IV LO DE TEA
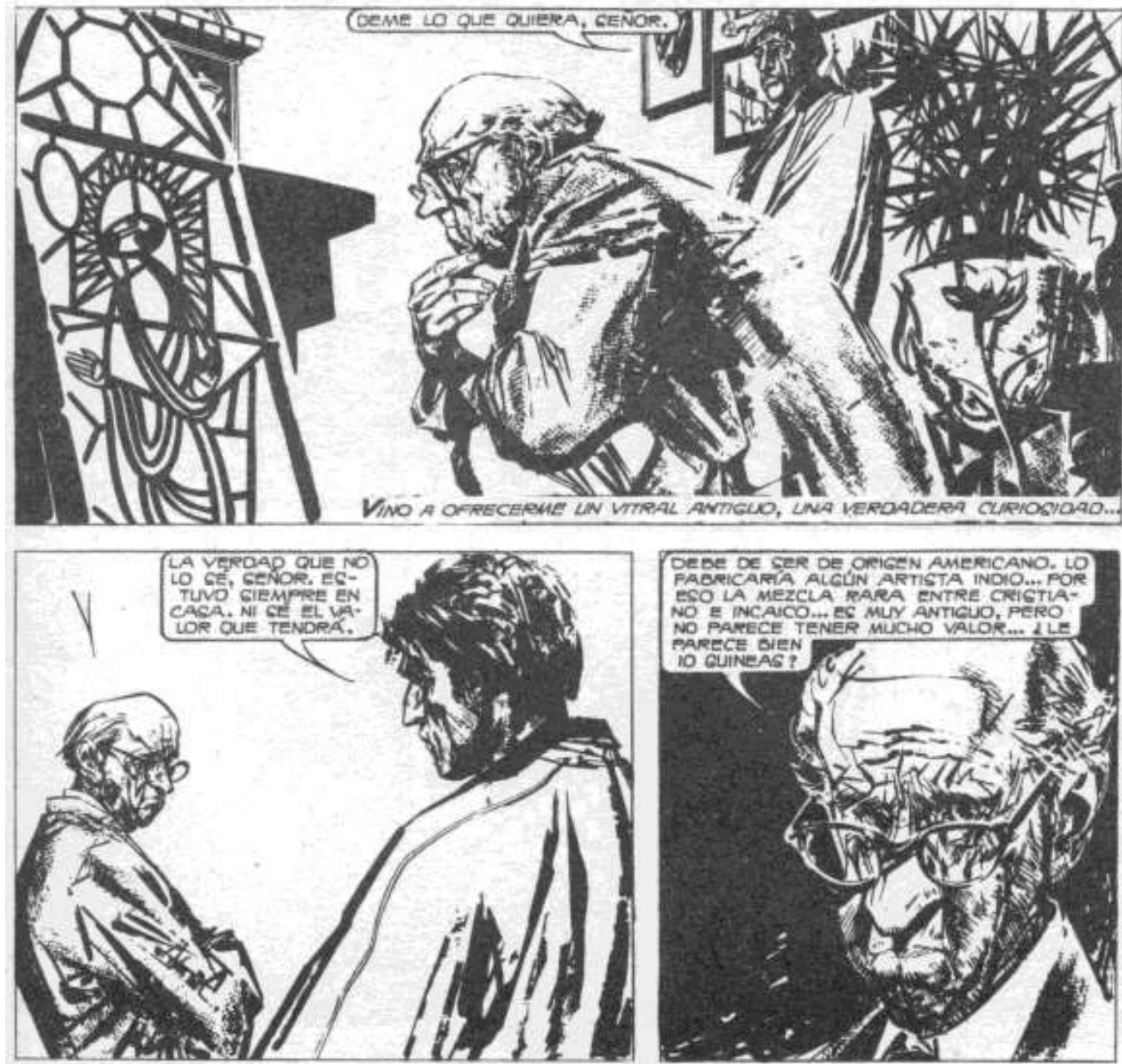

Fonte: acervo do autor. 
Por fim, outro exemplo, é o último capítulo intitulado "A batalla de las Termópilas" (A batalha das Termópilas), publicado originalmente na revista Misterix, entre janeiro e março de 1963, dos gêneros de aventura, bélico e histórico. Narra uma disputa entre os espartanos (e outros povos próximos) e os persas. Esses quadrinhos apresentam imagens panorâmicas das batalhas e tratam de temas como o castigo e a tortura.

De acordo com Gociol e Rosemberg (2003), também em 1962 ocorreu o início da publicação de outra história em quadrinhos: "Marcianeros", na revista Super Misterix, com roteiros de Oesterheld e, num primeiro momento, desenhos de Francisco Solano López. Posteriormente, contribuíram, como desenhistas para esses quadrinhos, Julio Schiaffino e Hugo Di Benedetto. Do gênero de ficção científica, essa história teve mais de cem páginas.

Já no livro Oesterheld en tercera persona (2008) informa-se que Oesterheld também colaborou nas revistas Casco de Acero e Casco de Acero Extra de José Alegre Asmar, entre os anos de 1962 e 1965, com histórias em quadrinhos de temáticas policiais, de cowboy e de guerra.

Oesterheld também prestou serviços para a Editora Atlántida, por cerca de uma década, publicando, por exemplo, os quadrinhos de ficção científica "Rumbo a las estrellas", com desenhos de Eugenio Zoppi, entre fevereiro e março de 1965.

Montero (2013) lembra que quando dirigiu a revista Géminis, em junho de 1965 (com a publicação de apenas duas edições), Oesterheld também desenvolveu um trabalho com o gênero da ficção científica. Ressalta-se, porém, que embora tenha sido curto esse espaço de tempo, foi nesse momento que publicou dois de seus princiapais contos: "El árbol de la buena muerte" e "Una muerte".

Montero (2013) também lembra que, após uma viagem de sete meses pela Europa, Oesterheld trabalhou no Chile, o que coincide com as informações do livro Oesterheld en tercera persona (2008), o qual registra a participação ativa de Oesterheld na história da produção quadrinística desse país, tendo entre os anos de 1967 e 1969 colaborado em algumas revistas, 
como: U-2, Far West, Ruta 44 e El Pinguino. Díaz [entre 2003 e 2018] também menciona o trabalho de Oesterheld nas publicações Far West, Ruta 44 e El Pinguino. Montero (2013) cita as editoras chilenas Zig Zag e Lord Cochrane como contratantes dos trabalhos de Oesterheld.

Hasson (2014) também menciona a contribuição de Oesterheld na história em quadrinhos Far West, por meio da série "Ronnie el Muertero". Esses quadrinhos contaram com desenhos de Enrique Breccia. Far West foi uma publicação da editora Zig Zag, que teve início no ano de 1966, sendo publicados cento e trinta e dois números desta história em quadrinhos.

É válido lembrar o ambiente político chileno da época, durante a década de 1960, que culminou com a eleição do médico socialista Salvador Allende como presidente do Chile, em 1970, o que acarretou mudanças econômicas e sociais nesse país, influenciando também a produção quadrinística. O período de governo de Allende foi tratado, no âmbito dos quadrinhos, por meio da graphic novel Los Años de Allende: novela gráfica, com roteiro de Carlos Reyes e desenhos de Rodrigo Elgueta, publicada na cidade de Santiago, pela editora Hueders, em 2015 (para um maior detalhamento acerca da produção quadrinística chilena e, em específico, dessa graphic novel, ver o capítulo quatro desta tese).

Montero (2013) lembra que, retornando ao território argentino, Oesterheld recebeu uma proposta da editora Jorge Álvarez, acerca de uma coleção sobre personagens históricos do continente americano. O primeiro volume dessa série foi uma biografia sobre Ernesto "Che" Guevara, o qual foi feito em parceria com os desenhistas Alberto e Enrique Breccia, com o título de Che. Esse título foi publicado no Brasil pela editora Conrad, em 2008, sob o título Che: os últimos dias de um herói, em preto e branco, num total de noventa e seis páginas, que inclui também um prólogo de Ernesto Sábato e uma nota para a edição brasileira, redigida por Rogério de Campos.

Essa graphic novel conta com sete capítulos: Bolívia, Ernestito, O Porco, O Che, Sierra Maestra, Yuro e, por fim, La Higuera. Esses itens não estão expostos de modo cronológico e apresentam ao leitor diversas passagens da vida de Ernesto "Che" Guevara, incluindo tanto os fatos familiares, os seus 
relacionamentos afetivos, a sua época de estudante de Medicina, como também o processo de formação de sua consciência política e também sua atuação prática nas lutas pelo fim dos processos de exploração existentes no mundo contemporâneo, principalmente em Cuba (durante o processo de desenvolvimento da Revolução Cubana) e na Bolívia (em um grupo armado), lembrando de suas passagens pela Guatemala e pelo México.

Essa publicação apresenta também ao leitor uma passagem importante da vida de Ernesto "Che" Guevara: uma busca pelas origens das problemáticas sociais, o que desloca seu interesse pela Medicina (tratamento da lepra, da malária e do tifo, por exemplo) para uma luta pelo fim das diversas formas de injustiças sociais, a qual, segundo seu pensamento, estaria ligada ao lucro e, portanto, ao modo de produção capitalista. E, a partir desse diagnóstico, passou a defender uma revolução profunda, em favor da constituição de uma sociedade socialista. Nesse sentido, é possível afirmar que essa história em quadrinhos possui um elemento pedagógico, no sentido de explicar ao leitor a formação, ou seja, a origem de várias das desigualdades sociais existentes no mundo contemporâneo, com foco sobretudo na América Latina. E, além disso, apontar para esse mesmo leitor uma possível saída para a resolução dessa problemática política e social. A figura trinta apresenta a capa desta graphic novel:

Fig. 30 - Capa da graphic novel Che: os últimos dias de um herói.

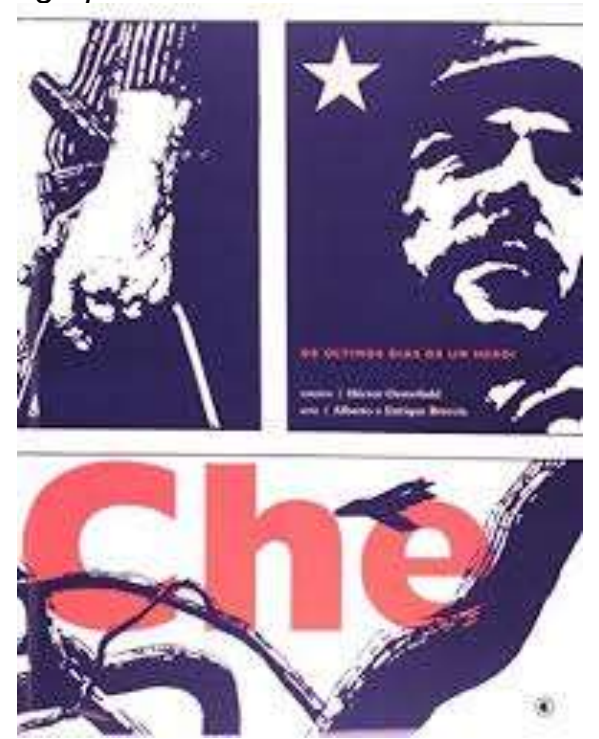

Fonte: Sistema Municipal de Bibliotecas Públicas da cidade de São Paulo. 
De acordo com Gociol (2007) e Campos (2008), Che foi publicada pela primeira vez em janeiro de 1968. Contudo, Montero (2013) alerta que é mais razoável que a primeira edição tenha ocorrido em janeiro de 1969, por dois motivos fundamentais: janeiro de 1968 é apenas três meses após a morte de "Che" Guevara (fato que ocorreu em 9 de outubro de 1967), além do fato de que a primeira edição do diário boliviano de Guevara se tornou conhecido do público apenas em julho de 1968, publicação essa fundamental para que Oesterheld tenha escrito o roteiro da história em quadrinhos Che.

Nesse momento de sua vida, Oesterheld possuía uma identificação muito profunda com a figura de Ernesto "Che" Guevara. Oesterheld chegou a afirmar, nessa época, que considerava Guevara como o melhor escritor argentino, em função, por exemplo, das suas reflexões críticas acerca dos problemas da América Latina (como as relações de exploração e injustiças) e da necessidade da ação prática. Nos termos de Monteiro (2013): "Basta de falar, há que defender a esperança". (MONTERO, 2013, p. 103, tradução nossa) ${ }^{11}$.

Naquele momento histórico, Alberto Breccia também era um admirador de Ernesto "Che" Guevara. Todavia, seu filho, Enrique Breccia, que era um militante do movimento peronista, possuía algumas ressalvas em relação ao pensamento político de Guevara, ainda de acordo com Montero (2013).

Dezenas de milhares de exemplares dessa biografia foram vendidas, sendo que a primeira edição se esgotou rapidamente, chamando a atenção do público leitor argentino. No entanto, os militares também perceberam a repercussão dessa publicação, o que causou uma rápida reação do autoritário governo do general Onganía, que determinou o confisco e a posterior queima dos exemplares recolhidos.

De acordo Campos (2008), é mencionado que existem relatos de pessoas que destruíram seus exemplares, em função do medo da repressão dos militares. Campos (2008) também menciona, nessa mesma nota, que a família Breccia chegou a receber ameaças, em função da publicação desta história em quadrinhos. Na contracapa da edição brasileira dessa graphic novel consta

\footnotetext{
${ }^{11}$ Basta de hablar, hay que defender la esperanza.
} 
a informação de que "a circulação do livro foi definitivamente proibida" no ano de $1973^{12}$.

Che pode ser considerada como sendo a primeira história em quadrinhos de Oesterheld a possuir um maior patamar de politização, estando mais próxima de um pensamento ideológico de esquerda, quando comparada com a sua produção quadrinística anterior. Com isso, a partir desse momento de seu trabalho intelectual como roteirista, os quadrinhos de Oesterheld passaram a refletir a sociedade e, cada vez mais, a questioná-la por meio de uma visão de mundo crítica em relação ao mundo capitalista.

Dito de outro modo, pode-se afirmar que Che marca uma passagem importante da produção quadrinística e trajetória intelectual de Oesterheld, a de um profundo humanismo para um compromisso político militante, próximo do socialismo científico de Karl Marx, o que, no contexto argentino daquele momento histórico poderia guardar algum paralelo com o peronismo de esquerda. Desse modo, a partir desse momento, suas histórias em quadrinhos passam a ter um maior patamar de análise e problematização políticas. Tal fato revela um processo de significativa mudança em sua percepção do mundo, em direção a um pensamento e a uma prática militante mais próxima das atividades políticas vinculadas ao socialismo, o que terá repercussão em quase toda a sua produção quadrinística a partir de então e, talvez mais ainda, na sua vida cotidiana (particular e familiar).

Como lembra José Muñoz (2013), quando se refere à pessoa de Oesterheld: "Você desceu em direção à história, deixou o antiperonismo e se transformou em um militante da pátria socialista". (MUÑOZ, José, 2013, p. 9, tradução nossa) $)^{13}$. Ou, novamente de acordo com Montero (2013), referindose à participação política e social de Oesterheld: "em sua presença incondicional junto aos explorados e oprimidos, em sua decisão de assumir os

12 Em informação pessoal do próprio Alberto Breccia, transmitida ao orientador desta tese, em novembro de 1992, em Lucca, na Itália, durante uma exposição de histórias em quadrinhos, foi dito que a reedição dessa obra posteriormente só foi possível porque ele enterrou os originais no quintal de sua casa, em Buenos Aires, onde permaneceram durante vários anos.

${ }^{13}$ Usted bajó hacia la historia, dejó el antiperonismo y se transformó en un militante de la patria socialista. 
riscos de uma luta [...] através do qual pretende derrubar um sistema injusto". (MONTERO, 2013, p. 11, tradução nossa) ${ }^{14}$.

Oesterheld também colaborou para a revista Gente, por dois modos diversos: escrevendo crônicas futuristas e fazendo histórias em quadrinhos. Com o desenhista Alberto Breccia, publicou, nessa revista da editora Atlántida, a partir de 29 de maio de 1969, uma nova versão da obra El Eternauta, que possuía um roteiro muito parecido com o da primeira (com desenhos de Francisco Solano López, publicada entre 1957 e 1959). Contudo, em alguns momentos, essa segunda publicação (ocorrida em 1969) também possui alguns trechos narrativos mais politizados e está mais próxima de um pensamento de esquerda que a versão anterior (feita entre 1957 e 1959).

E, além disso, essa nova publicação de El Eternauta possuía desenhos diferenciados (em comparação com as imagens da edição realizada anteriormente, feitas por Solano López), num trabalho de reconstrução do ambiente que transmite ao leitor, em maior intensidade, uma certa sensação de angústia e inquietude, através de um ambiente desolado e pavoroso.

Essa nova contribuição para a história em quadrinhos El Eternauta foi realizada por meio do trabalho criativo e inovador de Alberto Breccia, que fazia uso, como estratégia de apresentação gráfica, combinações envolvendo o branco e o negro, numa estética expressionista, e num exercício de arte experimental, que transmitia ao leitor um ambiente fantasmagórico, que auxilia na tomada de consciência política e social por parte do público leitor.

Lembra-se que, por vezes, os padrões estéticos são alterados segundo o contexto histórico e social, no sentido de que as percepções e as visões de mundo, dos atores sociais e dos grupos societários, são modificadas ao longo da História e também por questões culturais (e também políticas).

A figura trinta e um apresenta ao leitor, tanto em relação ao ambiente, como também no que se refere aos traços dos personagens, esse cenário de aflição e agonia, tendo em vista o trabalho realizado com as imagens pelo

\footnotetext{
${ }^{14}$ En sua presencia incondicional junto a los exploratos y oprimidos, en su decisión de asumir los riesgos de una lucha [...] a través del cual pretende derribar um sistema injusto.
} 
desenhista Alberto Breccia, o que representa também um exemplo de sua busca por uma renovação incessante das técnicas artísticas aplicadas aos desenhos das histórias em quadrinhos.

Fig. 31 - Ambientes e personagens apresentados ao leitor por meio da estética expressionista de Alberto Breccia nos quadrinhos El Eternauta (Oesterheld e Alberto Breccia).
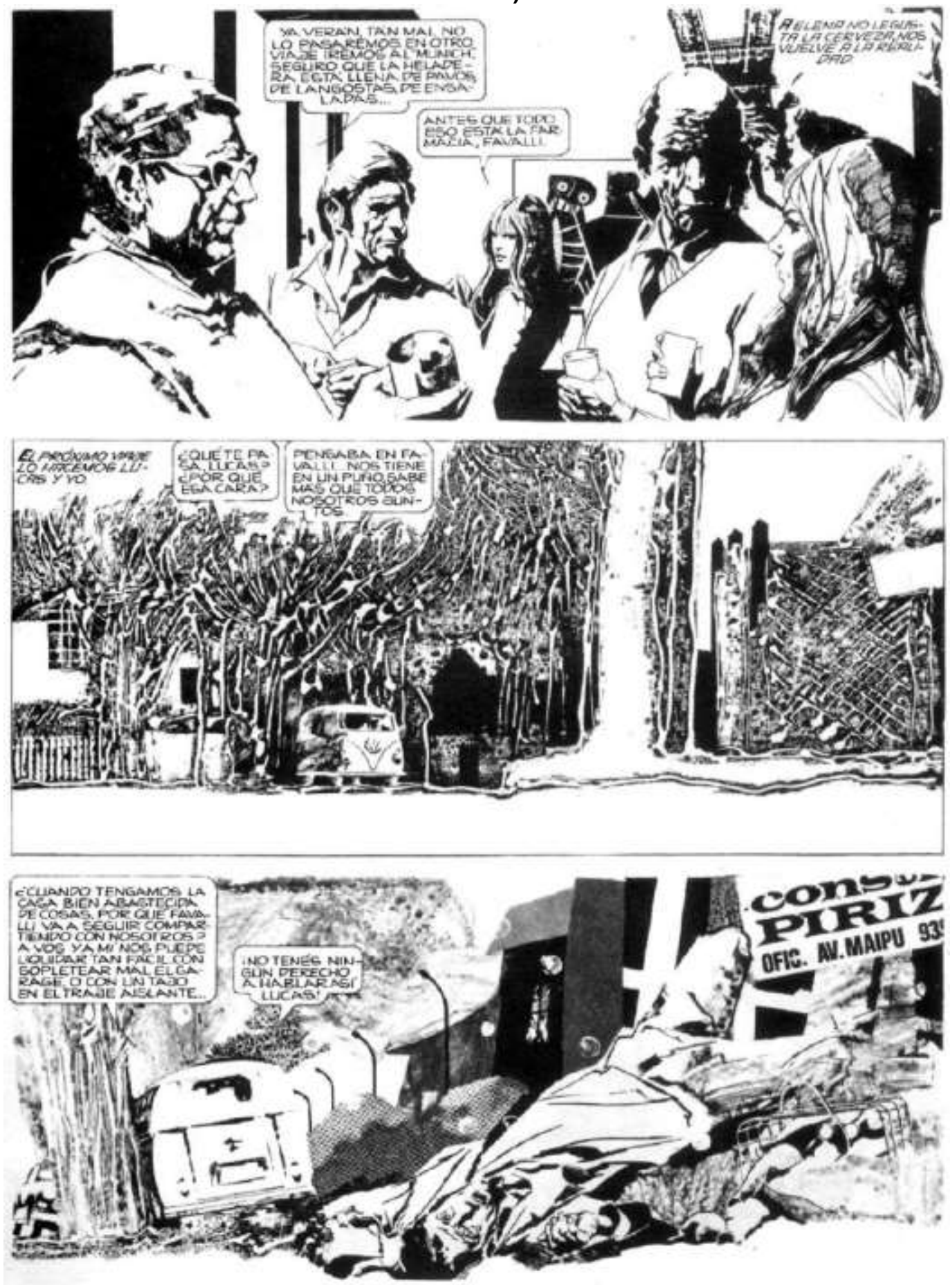

34FL EERNAUT':

Fonte: acervo do autor. 
Nessa história em quadrinhos fica reforçado que o pensamento de Oesterheld, nessa época, tinha sofrido uma sensível reformulação ideológica, quando comparado com a década de 1950, e já estava fortemente influenciado pelas teorias sociais e práticas políticas de Karl Marx e Ernesto “Che” Guevara.

Lembra-se também o momento histórico da América Latina, com a Revolução Cubana e, em específico, da Argentina, com o evento, por exemplo, do cordobazo, já anteriormente mencionado. Para se ter uma noção de tal fato, nessa história em quadrinhos, um dos protagonistas da história, o personagem Favalli, chega a associar a nevada mortal, que permeia a narrativa de El Eternauta, com questões próprias da América Latina, como o atraso social e a miséria econômica. Em uma de suas falas, quando menciona os processos de exploração pelos quais a América Latina já passou, tendo em vista diversos processos de dominação realizados pelas nações ricas, Favalli relata: "Suas nevadas mortais eram a miséria, o atraso [...]”. (MONTERO, 2013, p. 114, tradução nossa) ${ }^{15}$. Tal fato é apresentado na figura trinta e dois:

Fig. 32 - Discurso de Favalli associando uma possível exploração dos países mais ricos com a pobreza da América do Sul, nos quadrinhos El Eternauta (Oesterheld e Alberto Breccia).
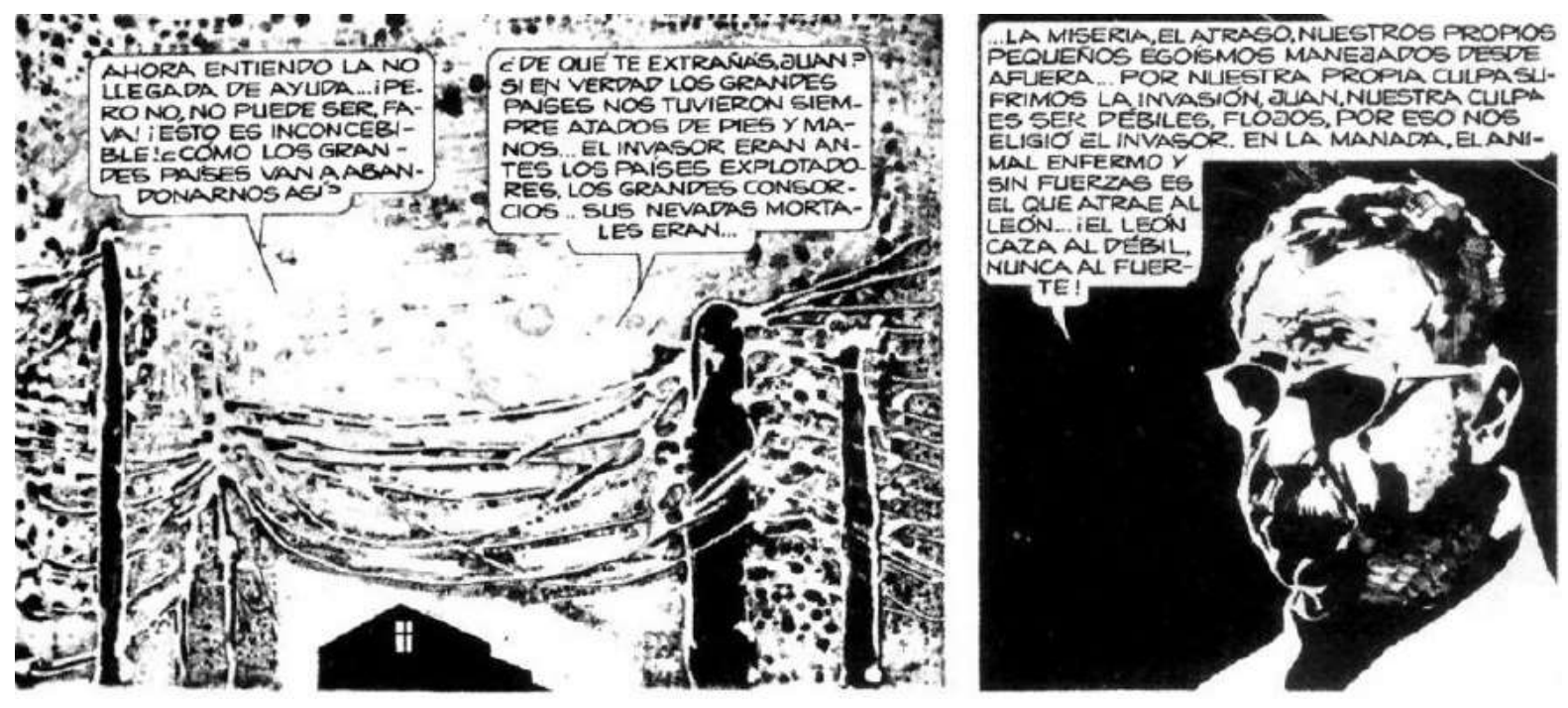

Fonte: acervo do autor.

\footnotetext{
${ }^{15}$ Sus nevadas mortales eran la miséria, el atraso [...].
} 
Nessa versão de El Eternauta, as grandes potências mundiais entram em acordo com os invasores para não serem atacadas; em troca fornecem aos extraterrestres toda a América do Sul, como pode ser observado na leitura do último quadrinho da figura trinta e três.

É válido lembrar o cenário social da época, com uma valorização da temática do nacionalismo e também das análises políticas de Ernesto "Che" Guevara, das quais Oesterheld era leitor e que tratam, entre outros temas, da exploração social e econômica de algumas nações sobre outras. "Che" Guevara também menciona a cumplicidade das elites nacionais (ou, em termos marxistas, das "burguesias nacionais") com os países ricos em desfavor das classes que vivem do trabalho.

De acordo com essa linha de raciocínio, os monopólios estrangeiros teriam parcerias com os proprietários dos meios relevantes de produção desses países, ou seja, as "elites nacionais", fazendo com que esses estratos sociais mais privilegiados em termos econômicos tivessem uma visão de mundo parecida com o ideário dos habitantes das nações desenvolvidas (e não de seus países).

Ainda de acordo com esse pensamento, esses grupos nacionais privilegiados teriam, em função do seu poder econômico, acesso privilegiado às agências de informação e aos meios de comunicação, sendo, predominantemente, proprietários destes.

Desse modo, os estratos sociais mais pobres estariam submetidos a uma forma de "violência cultural" ou, dito em outros termos, uma "colonização pedagógica", que facilitaria o domínio desses estratos sociais dominantes, pois as camadas sociais desfavorecidas teriam seguidos obstáculos para uma maior conscientização em relação às problemáticas culturais, econômicas e políticas de suas sociedades. Tal fato, a despolitização das massas, faria com que poucos membros dessas camadas sociais tenham consciência e organização para atuar em favor de mudanças substanciais nesse sistema. 
Fig. 33 - As grandes potências entregam a América do Sul aos invasores extraterrestres nos quadrinhos El Eternauta (Oesterheld e Alberto Breccia).

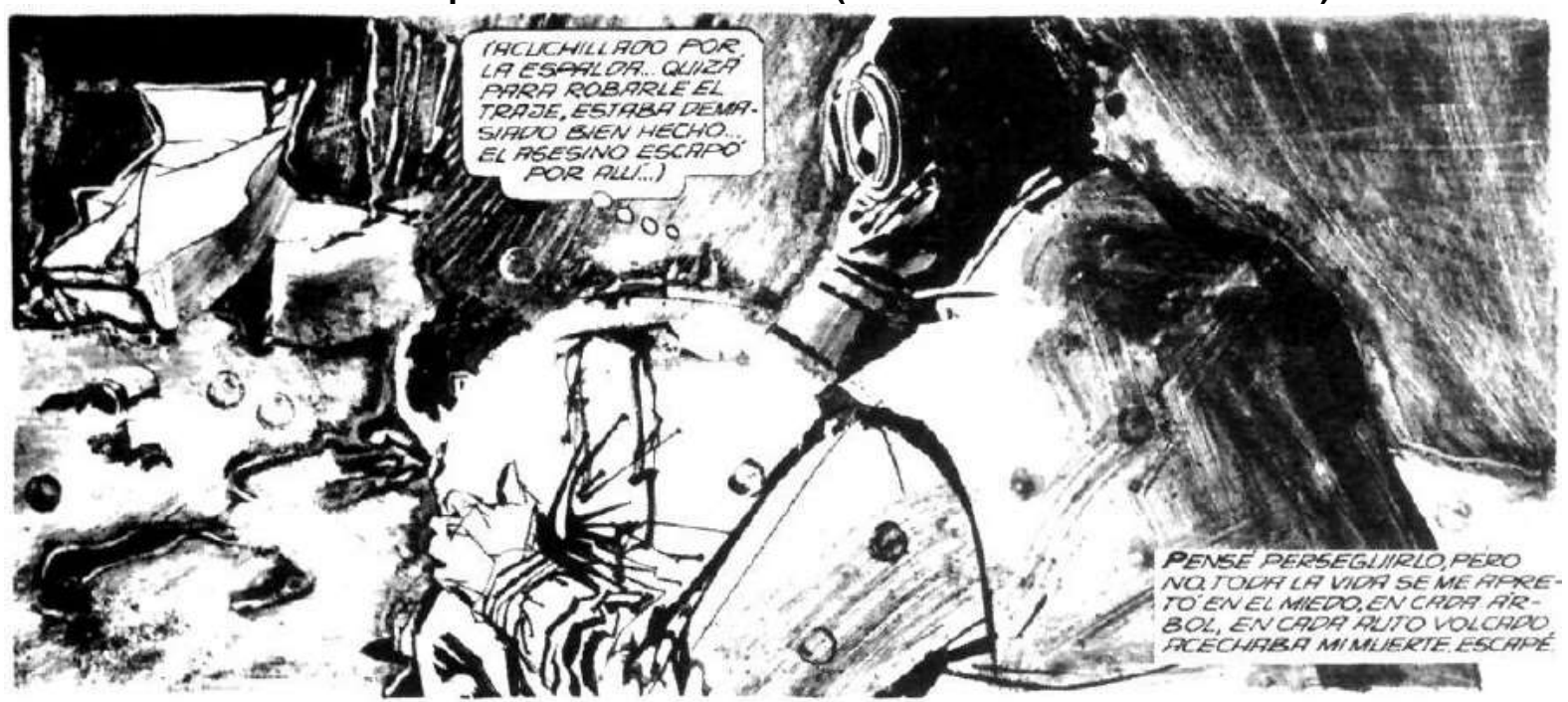

LLCAS APENAS MN MUERTO TANTOS PERO SUMLERTE NOS GOLPEA COMO SIFLERA $\angle A \cup N$ CA. ANREE TANTO GNOUNLANEN ONOS CREH MI OE VIO DE SEGURIO
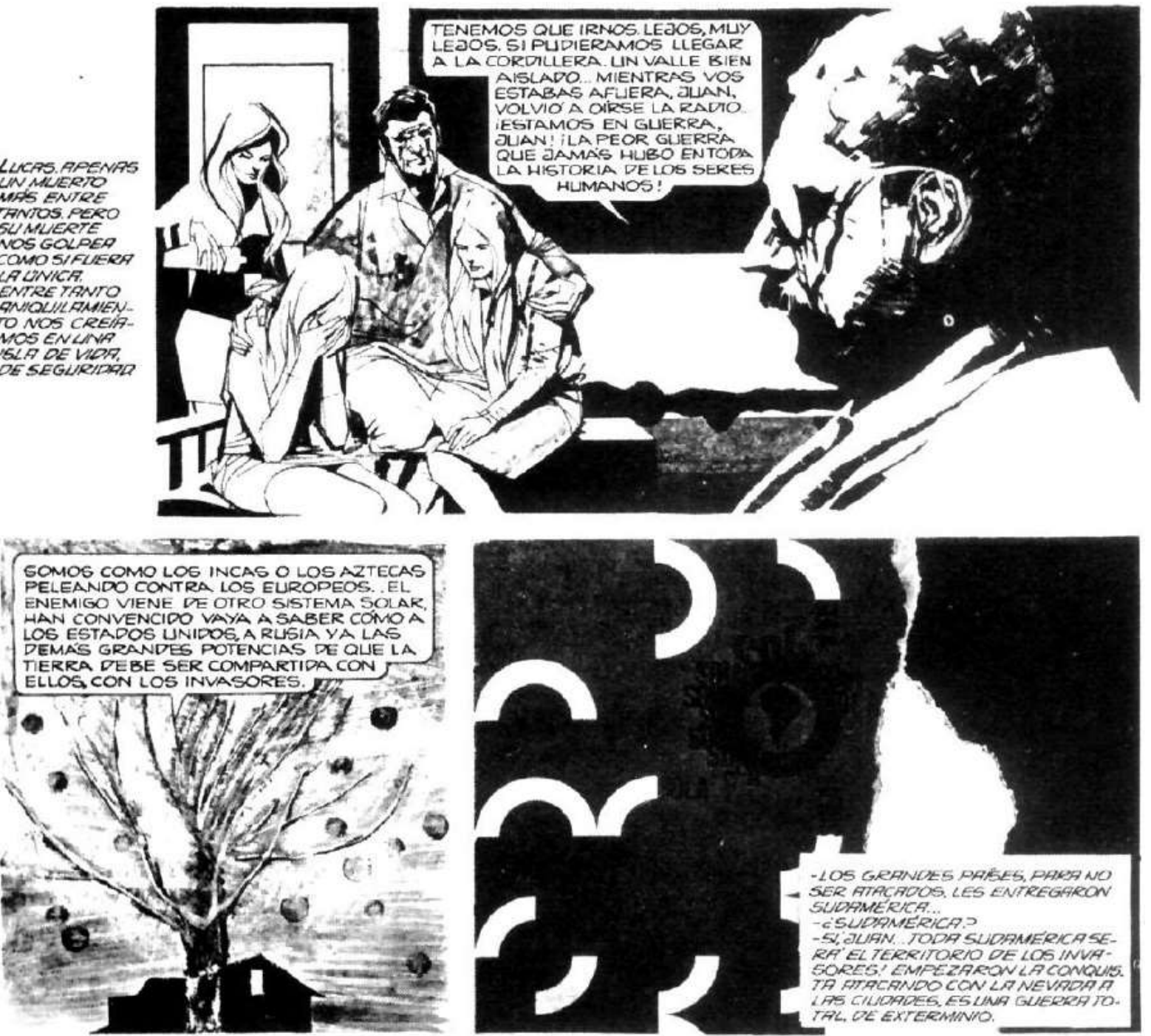

EL ETERNAUTA 37

Fonte: acervo do autor. 
Tanto nos quadrinhos El Eternauta desenhados por Alberto Breccia, como por Francisco Solano López, o personagem Eternauta consegue, ao término da história, reencontrar com sua esposa e filha, em um retorno a sua residência, não lembrando mais dos fatos ocorridos em seu percurso como navegante do tempo. Portanto, é possível dizer que essa história é circular. Tal fato é apresentado na figura trinta e quatro:

Fig. 34 - $O$ reencontro do personagem $O$ Eternauta com sua família nos quadrinhos El Eternauta (Oesterheld e Alberto Breccia).

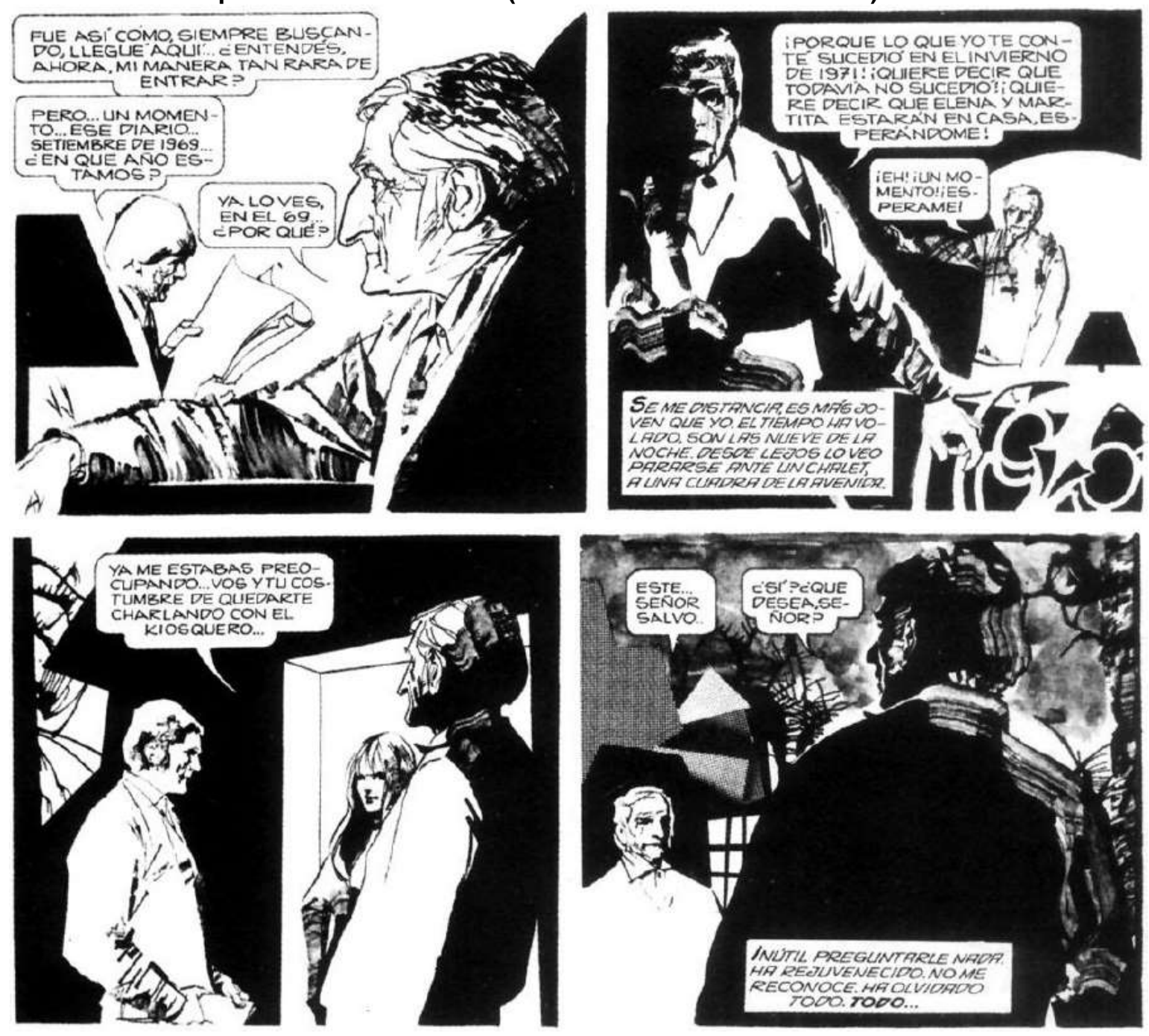

Fonte: acervo do autor.

Lembra-se, no entanto, que essa versão de El Eternauta teve o seu relato abreviado, por solicitação da editora, até mesmo porque a linha editorial da 
revista Gente, que nesse momento era comercializada na Argentina e no Paraguai, estava mais próxima do espectro ideológico da direita, entrando, portanto, em conflito com a produção e exposição ao leitor, nessa publicação, desta história em quadrinhos. Tal fato pode ser entendido como um caso de censura editorial em relação ao trabalho quadrinístico de Oesterheld e Alberto Breccia, o que explicita um mecanismo de silenciamento de um trabalho artístico e também crítico em relação às problemáticas latino-americanas tratadas nesta obra.

Com isso, essa versão de El Eternauta acabou sendo uma narrativa mais curta quando comparada com a versão anterior, realizada pela parceria entre o roteirista Oesterheld e o desenhista Solano López. É provável que, conscientemente, Oesterheld tenha resumido algumas passagens, nessa versão feita com as ilustrações de Alberto Breccia. Inclusive, a figura trinta e cinco é sugestiva a esse respeito, principalmente no início da fala do personagem Eternauta, quando menciona, logo no início de sua fala, que está pulando etapas em sua narrativa.

Fig. 35 - $O$ personagem Eternauta narrando o andamento da história em quadrinhos El Eternauta (Oesterheld e Alberto Breccia).

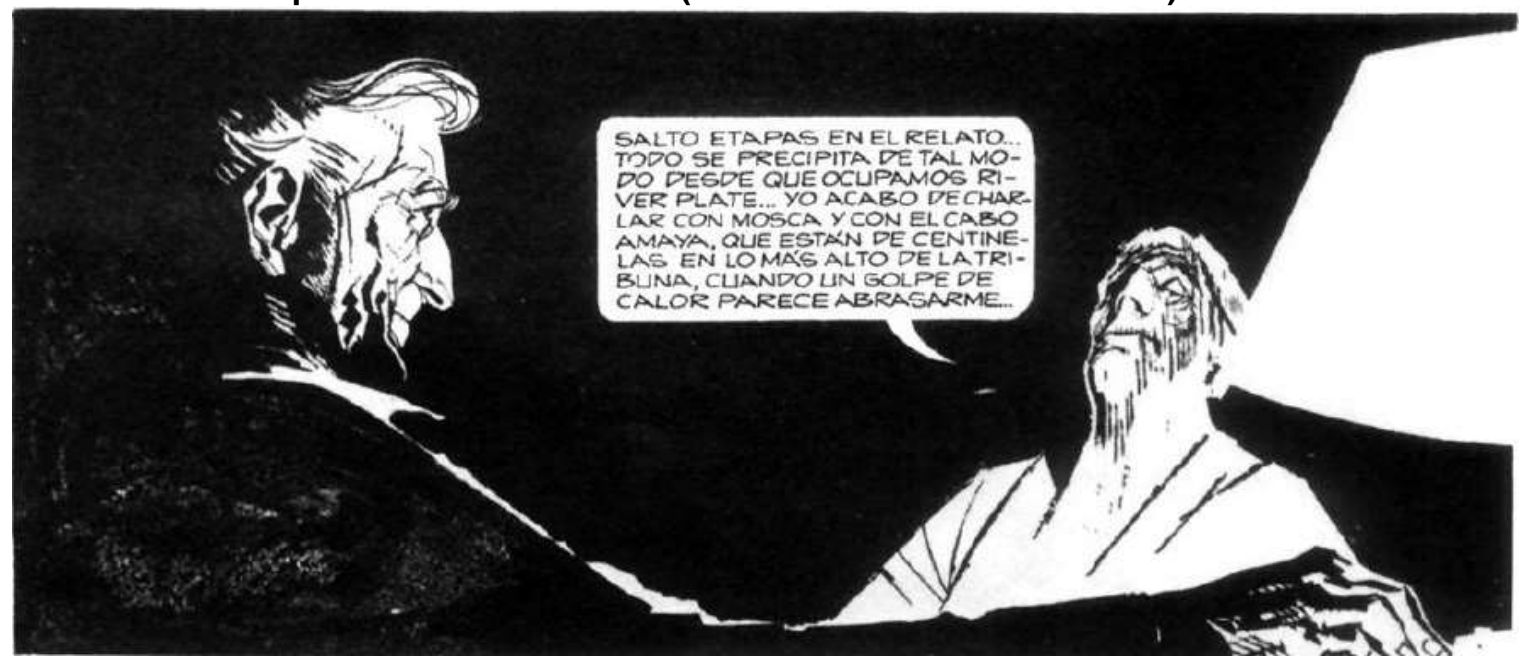

Fonte: acervo do autor.

Tanto Montero (2013) como a publicação Oesterheld en tercera persona (2008) lembram que o roteirista Oesterheld também teve trabalhos publicados pela editora Columba, num breve período, no ano de 1958 (em específico na 
revista El Tony), e entre os anos de 1972 e 1976, com histórias em quadrinhos que tinham temáticas como a aventura, o esporte, a guerra e o gênero policial. Nesse sentido, Montero (2013) afirma que as contribuições de Oesterheld nesta editora, durante os anos 1970, estavam ligadas, principalmente, ao fato de Oesterheld estar nitidamente com problemas econômicos. Salta aos olhos o fato dessa editora ter uma linha ideológica e trabalhar com publicações distantes do perfil da produção quadrinística de Oesterheld, nesse momento de sua vida.

Em 1973 Oesterheld começa a escrever o roteiro da história em quadrinhos "Latinoamérica y el imperialismo. 450 años de guerra", a qual apareceu na publicação montonera El Descamisado, um semanário de atualidades políticas, tendo como ilustrador Leopoldo Durañona. Esses quadrinhos foram publicados entre julho de 1973 e abril de 1974, de acordo com Balletta (2017).

Essa história em quadrinhos foi pensada com o objetivo de se ter uma narrativa sobre a História da América Latina, do ponto de vista montonero, dando ênfase ao tema do protagonismo popular, em específico das classes que vivem do trabalho (ou, em termos marxistas, a classe social proletária e campesina). Também possui discursos favoráveis a uma possível revolução socialista.

Desse modo, tanto Oesterheld como os idealizadores dessa história utilizavam os quadrinhos como ferramenta pedagógica, um instrumento educativo para trabalhar com o esclarecimento político das massas, dos leitores dessa publicação a qual, de acordo com Gillespie (1998) e Montero (2013), chegou a ter uma tiragem e venda de aproximadamente cem mil exemplares semanais. Com isso, é possível dizer que Oesterheld, ao mesmo tempo, produzia histórias em quadrinhos e também expressava, nesse momento de sua produção quadrinística, sua condição de militante revolucionário, que buscava a emancipação das classes sociais que vivem do trabalho em relação à exploração e ao autoritarismo exercidos pelo capital e pelo Estado, entendendo este como uma instituição que atua em defesa dos 
estratos sociais dominantes. Ou seja, Oesterheld passa a ser um "roteirista da revolução", comprometido com o socialismo.

Em suma, pode-se dizer que Oesterheld buscava a formação de processos sociais que favorecessem a construção de uma nova configuração societária, na qual ocorresse uma alteração significativa da mentalidade do ser humano, saindo do egoísmo individualista do modo de produção capitalista em direção ao altruísmo e a construção de uma sociedade cooperativa de orientação socialista.

Tal fato fica marcado, principalmente, nos seus últimos trabalhos de roteirista de história em quadrinhos e também em sua militância política nos Montoneros, grupo esse que, de acordo com Ortega (2017), era uma organização de linha ideológica de esquerda, influenciado pelo peronismo, fundado em 1967.

Nesse sentido, lembra-se, ainda, que até o momento de iniciar seu trabalho na publicação El Descamisado, de acordo com Montero (2013), o único contato familiar de Oesterheld com a organização dos Montoneros foi por intermédio de sua filha Beatriz Marta Oesterheld, que ingressou nesse grupo no ano de 1973. El Descamisado foi fechado no ano seguinte por um decreto governamental (realizado pelo Ministerio del Interior), em 1974, pelo governo do general Juan Domingo Perón, de acordo com Gillespie (1998) e Montero (2013).

Nesse momento, Oesterheld estava cada vez mais ativo politicamente e crítico em relação ao cenário atual (da Argentina e da América Latina), buscando uma sociedade que, no futuro, não apresentasse nem opressores nem oprimidos, atuando, por meio do seu trabalho de roteirista de histórias em quadrinhos, em favor de um ideal de justiça e liberdade, que ele entendia ser o socialismo. Nesse contexto, começa a trabalhar sobre um novo projeto: 0 roteiro da história em quadrinhos "La Guerra de los Antartes", que começou a ser publicada em fevereiro de 1974 no jornal diário montonero Noticias (os quadrinhos também eram publicados com a periodicidade diária). De acordo com Gillespie (1998), Noticias chegou a ter vendas regulares de cento e cinquenta mil exemplares por dia. 
Oesterheld faz uso, nesse trabalho, do pseudônimo Francisco G. Vázquez. Os desenhos são feitos por Gustavo Trigo. Esses quadrinhos pertencem aos gêneros da ficção científica e político, e a história foi ambientada na cidade de Buenos Aires.

A história possui um personagem principal e narrador chamado Sabino Torres, além de um discurso perturbador e pessimista em relação à realidade atual. Por exemplo, é digno de nota a primeira frase da história em quadrinhos "La Guerra de los Antartes", que faz referência ao número significativo de mortes ocorridas. A figura trinta e seis apresenta o primeiro quadrinho desta história.

Fig. 36 - Primeiro quadrinho de La Guerra de los Antartes.

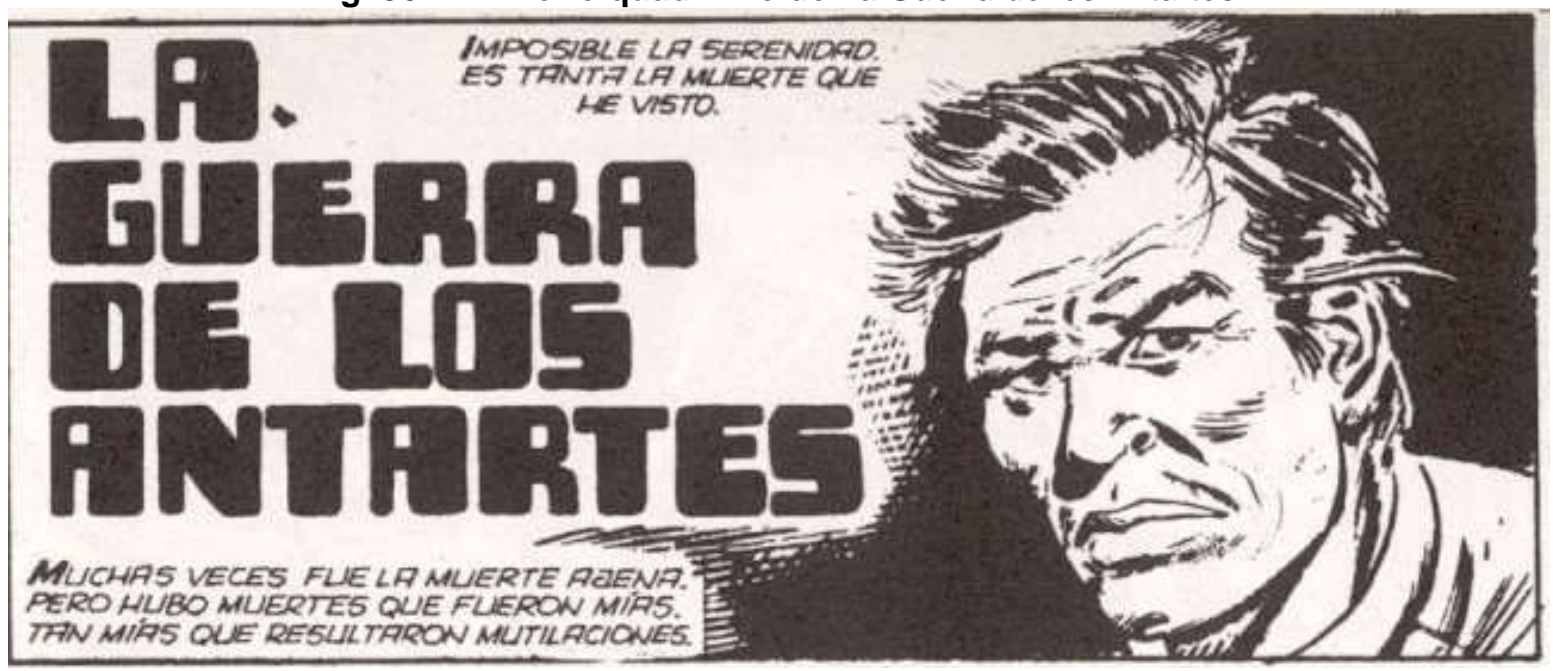

Fonte: acervo do orientador desta tese.

Essa história em quadrinhos trata da invasão do planeta Terra pelos extraterrestres antartes, os quais obtém um acordo de paz com as nações mais ricas da Terra, em troca de uma parte do mundo não desenvolvido, no caso, a América do Sul, sendo essa a mesma temática que foi desenvolvida na versão da história em quadrinhos El Eternauta, realizada por Oesterheld e Alberto Breccia.

Esses quadrinhos podem ser entendidos como uma metáfora política (em relação ao governo do general Juan Domingo Perón) e trata do 
desenvolvimento social e da resistência popular organizada pela sociedade civil, fazendo, inclusive, analogias com o grupo Montoneros, num cenário de opressão política. Chega também a tratar de uma possível experiência socialista na Argentina, que nessa história, possuía um governo popular.

Com isso, ela expõe (novamente) ao leitor, por meio de alegorias, em uma forma figurada, o comprometimento político do roteirista, ao tratar de temas de complexo entendimento no interior da realidade social latino-americana, como o conflito entre diferentes classes sociais, a distribuição de renda, a luta política e social, a reforma agrária e a socialização dos meios relevantes de produção. Inclusive, "La Guerra de los Antartes" chega a mencionar o golpe militar de Augusto Pinochet, em 1973, que destituiu da presidência o médico Salvador Allende, que havia sido eleito em 1970 (é adequado ressaltar que o fato político do golpe militar que havia ocorrido no Chile, aconteceu no ano anterior ao início da publicação dessa história em quadrinhos, na Argentina). A figura trinta e sete apresenta este quadrinho.

Fig. 37 - Menção ao golpe de Pinochet no Chile, em 1973, nos quadrinhos de La Guerra de los Antartes.

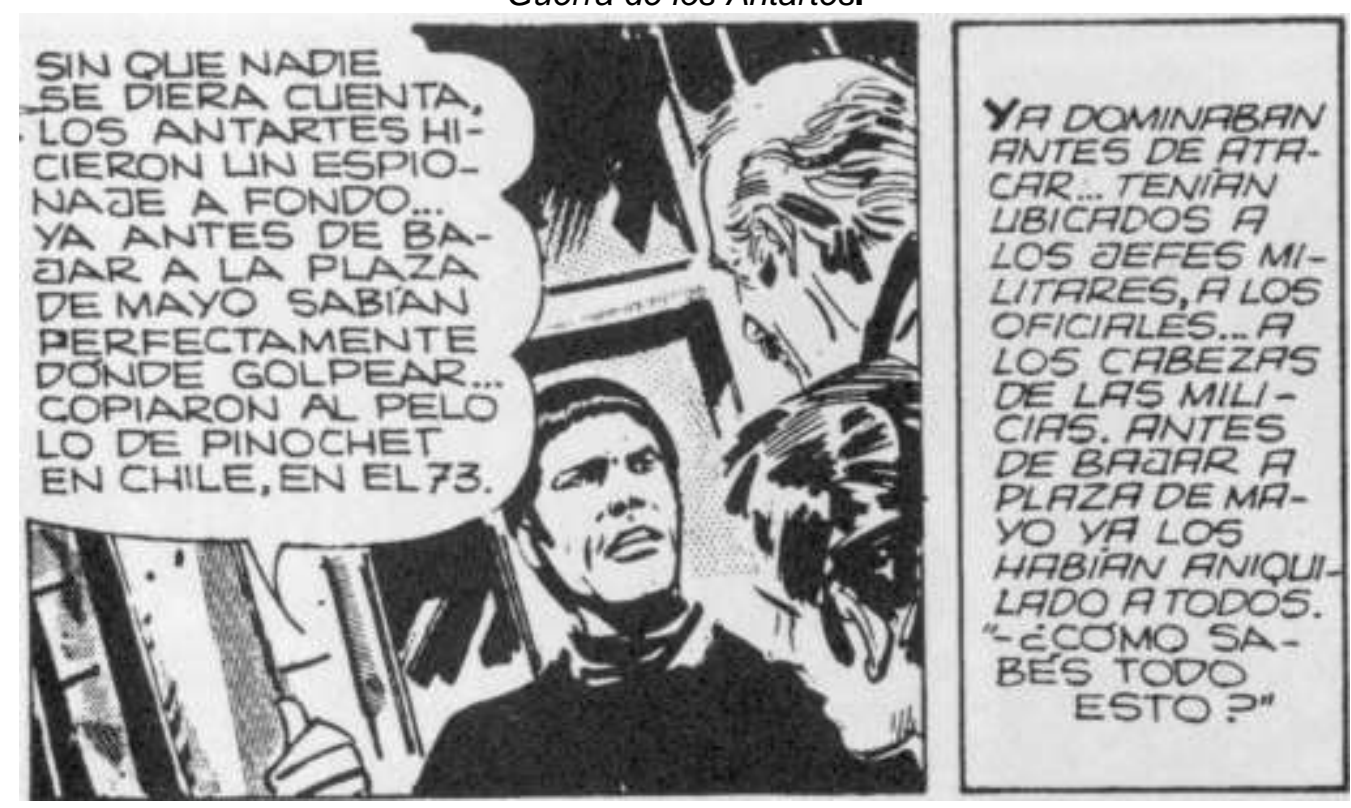

Fonte: acervo do orientador desta tese. 
No momento da publicação dessa história, Oesterheld já pertencia ao grupo político-militar dos Montoneros, sem ocupar cargo algum de direção. Colaborava na sua estrutura de imprensa, e esses quadrinhos refletem o seu pensamento (e ação política), de um membro da esquerda peronista. Nesse contexto, é necessário ressaltar um fato da maior importância na História política argentina, que foi a saída do grupo político-militar Montoneros do movimento peronista, na data de $1^{\circ}$ de maio de 1974 (dia do Trabalho). E, após dois meses, ocorre também o falecimento de Juan Domingo Perón, em 1ํ de julho de 1974, sendo sucedido por sua esposa Maria Estela Martínez de Perón, conhecida como "Isabel" ou "Isabelita" Perón. Posteriormente, de acordo com Ortega (2017), a organização Montoneros tornou-se ilegal, a partir de 8 de setembro de 1975, ainda sob o governo de Maria Estela Martínez de Perón.

Montero (2013), Gociol e Rosemberg (2003) e Von Sprecher (2007), ressaltam que o jornal Noticias foi fechado pelas forças policiais, que atuaram sob ordens do governo federal, em agosto de 1974. Tal fato fez com que "La Guerra de los Antartes" ficasse sem conclusão.

É adequado lembrar que nesse cenário político da passagem dos Montoneros para a clandestinidade, ocorriam três fatos importantes, do ponto de vista histórico: a ofensiva de um "esquadrão da morte" que assassinava socialistas, uma maior repressão das forças policiais regulares, além de uma preocupação com uma futura ofensiva do Exército.

Ao longo de sua história, os Montoneros criaram várias organizações de massas, de acordo com as necessidades dos movimentos sociais, tendo, com isso, uma capacidade significativa de mobilização popular e chegando, inclusive, a exercer uma justiça "paralela" ao Estado, ou, nos termos desse grupo, uma "justiça popular" em relação às pessoas que atuavam contra o povo. Nesse sentido, é preciso ressaltar que, de acordo com Gillespie (1998), para um maior esclarecimento acerca desse fato, é necessário contextualizar o momento político da época, no qual, ao longo do início dos anos 1970, uma quantidade significativa de pessoas com ideário de esquerda foi assassinada na Argentina. 
Gillespie (1998) também lembra que os Montoneros chegaram, inclusive, a ultrapassar o território argentino, em sua área de atuação, realizando operações comerciais em solo uruguaio.

Desse modo, considerando o cenário cultural, político e social daquele momento histórico, é possível considerar que tanto as histórias em quadrinhos "Latinoamérica y el imperialismo. 450 años de guerra" como "La Guerra de los Antartes" podem ser entendidas como quadrinhos políticos, pertencentes a uma "cultura montonera", de formação socialista, e que busca a conscientização dos povos latino-americanos sobre os mais variados temas políticos, ampliando também sua perspectiva histórica sobre a formação e os mais diversos conflitos existentes no interior desta região geográfica. Portanto, é possível afirmar que Oesterheld trabalhava com os roteiros de suas histórias em quadrinhos com o objetivo de fazer uso dos potenciais educativos desse meio de comunicação, ao apresentar ao leitor, de modo didático, as problemáticas culturais, econômicas, políticas e sociais contemporâneas da América Latina.

Além disso, Oesterheld também tinha um projeto para a produção de uma nova versão (ou continuação) das histórias em quadrinhos "Mort Cinder", que seria publicada na revista Información, publicação essa também ligada ao grupo político dos Montoneros. Contudo, o projeto não foi adiante.

De acordo com o livro Oesterheld en tercera persona (2008), outra revista que também publicou trabalhos de Oesterheld foi a Skorpio, pertencente à editora Record, que foi lançada no mercado em 1974. As contribuições de Oesterheld estão nas edições dessa revista entre os anos de 1975 e 1976. Ressalta-se, porém, que outras publicações ocorreram, posteriores ao ano de sua provável morte, em 1978.

Gociol e Rosemberg (2003) mencionam como um exemplo do trabalho de Oesterheld para a revista Skorpio o roteiro dos quadrinhos "Nekrodamus", com desenhos de Horacio Lalia. Essa história narra a existência de um demônio com ar gótico que não tem interesse em usar seus poderes para o mal. $O$ personagem Nekrodamus é um espírito que usa o corpo de um conde que faleceu recentemente. 
O início da publicação desses quadrinhos data do ano de 1975 e ocorre até o desaparecimento de Oesterheld. Posteriormente, a partir dos anos 1980, também com desenhos de Horacio Lalia, os roteiros foram feitos por Ray Collins e Walter Slavich.

Montero (2013), menciona que outra publicação de Oesterheld, as histórias em quadrinhos El Eternauta II, começou a ser vendida em dezembro de 1976, o que ocorreu até abril de 1978. A história foi dividida em vinte e sete episódios, na publicação El Libro de oro de Skorpio. Com isso, a venda das histórias em quadrinhos El Eternauta II estava ocorrendo em meio ao fato de Oesterheld estar num primeiro momento na clandestinidade e, posteriormente, desaparecido.

El Eternauta I/ foi produzida em um ambiente de tensão social e de conflito de classes sociais muito acentuado, em tempos de violência política, e pode ser lida como uma aventura e, num certo sentido, como uma possível metáfora de um sonho guerrilheiro. Como lembra Montero (2013):

\begin{abstract}
Porque todos os que lemos seus quadrinhos quando éramos jovens nos sentíamos parte dessa aventura, pelo menos por um tempo; por esse tempo demorávamos a fechar a revista e seguir com a rotina. Porque aqueles de nós que conhecemos sua travessia política não podemos nos conformar em resgatar das garras do esquecimento apenas seu trabalho, grande e transgressor. [...] sabemos que todo o trajeto está marcado por mensagens cifradas que tanto nos explicam deste presente. Porque se, de certa forma, é verdade que escrever aventura é vivê-la; queremos acompanhar Héctor nessa viagem até escutar sua voz. Até nos sentirmos parte dessa gigantesca aventura, complexa e tão humana que ele escolheu chamar Revolução. (MONTERO, 2013, p. 93, tradução nossa) ${ }^{16}$.
\end{abstract}

\footnotetext{
${ }^{16}$ Porque todos los que leímos sus historietas cuando éramos pibes nos sentimos parte de esa aventura, al menos por un rato; por ese tempo que demorábamos em cerrar la revista y seguir con la rutina. Porque los que conocemos su travesía política no podemos conformarnos con rescatar de las garras del olvido sólo su trabajo, genial y transgresor. [...] sabemos que todo el trayecto está marcado por mensajes cifrados que tanto nos explican de este presente. Porque si, en cierto modo, es verdade que escribir la aventura es vivirla; queremos acompañar a Héctor en ese viaje hasta escuchar su voz. Hasta sentirnos parte de esa aventura gigante, compleja y tan humana que él eligió llamar Revolución.
} 
Francisco Solano López desenhou El Eternauta II com ressalvas, em função do caráter fortemente combativo e politizado dos roteiros. O desenhista, de acordo com Montero (2013), chegou a fazer uma reclamação para a editora, pois, devido ao contexto nacional, o teor desses quadrinhos, poderia, potencialmente, colocar a todos os envolvidos nessa produção em risco. Solano López chegou a tratar desse tema também com Oesterheld (como dito anteriormente, nesse momento, na clandestinidade), numa primeira vez, por telefone, e, num segundo momento, pessoalmente.

Nessa etapa de sua vida, Oesterheld estava cada vez mais envolvido com a organização política dos Montoneros, na sua estrutura de imprensa e, em particular, com os informes de conjuntura desta organização. Portanto, os Montoneros tinham também uma preocupação significativa de anunciar o seu programa político por meio de um discurso visual, fazendo uso intenso das histórias em quadrinhos.

Tendo em vista o exposto acima, é importante sublinhar que toda a produção de Oesterheld, o que inclui a literatura infantil, de ficção científica e os roteiros de histórias em quadrinhos, foi marcado pelo seu pensamento e sua prática de valorização do ser humano e da sua luta pela justiça social e liberdade dos indivíduos. Como lembra Montero (2013):

Nesse trânsito simbólico prenunciam muitas das ideias que o roteirista defenderá com sua vida [...] a extraordinária imagem do escritor que rompe os parâmetros conhecidos, que cruza a fronteira dos vencedores para começar a reler e reescrever a história do ponto de vista dos vencidos; sem intermediários, sem o olhar misericordioso dos que deixam um pé em cada lado [...]. Não só para contar, mas também para viver a sorte dos vencidos, a dos explorados e oprimidos. E, a partir deste novo lugar, modificar sua visão das coisas. (MONTERO, 2013, p. 93, tradução nossa) ${ }^{17}$.

\footnotetext{
${ }^{17}$ En ese trânsito simbólico se prefiguran muchas de las ideas que el guionista defenderá con su vida [...] la extraordinária imagen del escritor que rompe los parámetros conocidos, que cruza la frontera de los vencedores para comenzar a releer y reescribir la historia desde el punto de vista de los vencidos; sin intermediarios, sin la mirada piadosa de los que dejan un pie em cada lado [...]. No sólo para contar, sino también para vivir la suerte de los vencidos, la de los explotados y oprimidos. Y, desde ese nuevo lugar, modificar su visión de las cosas.
} 
Em específico sobre essa produção quadrinística oesterheldiana, é possível afirmar que essas histórias em quadrinhos influenciaram os roteiristas argentinos da geração posterior a Oesterheld, sendo possível citar, por exemplo: Carlos Sampayo, Carlos Trillo, Guillermo Saccomanno, Juan Sasturain e Ricardo Barreiro.

Essa influência chegou até mesmo a uma geração subsequente à desses roteiristas, sendo possível citar, por exemplo, o trabalho quadrinístico do argentino Salvador Sanz, nascido em 1975. É adequado lembrar que Sanz teve trabalhos quadrinísticos publicados também no Brasil, tais como: Noturno, $O$ Esqueleto: o início e O Esqueleto: o museu esquecido, esses três pela editora Zarabatana. A figura trinta e oito apresenta capa da primeira edição de $O$ Esqueleto: o início.

Fig. 38 - Capa da história em quadrinhos $O$ Esqueleto: o início.

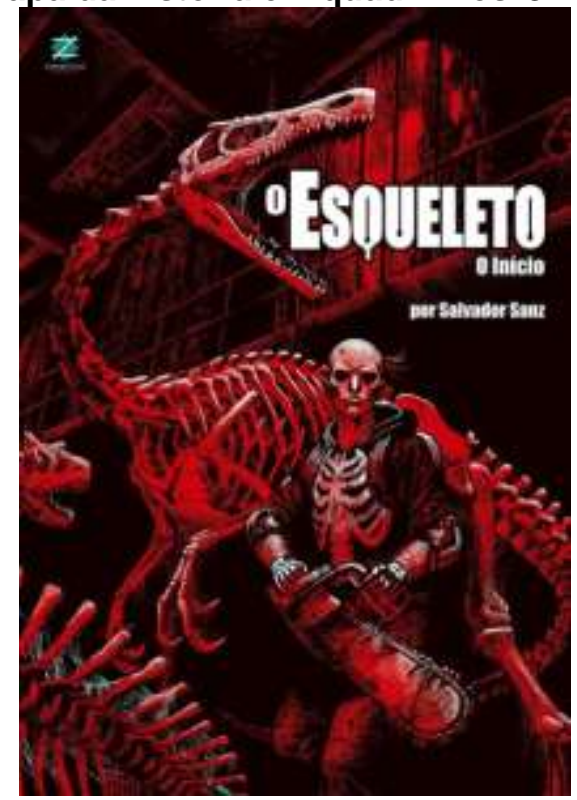

Fonte: acervo do autor.

Von Sprecher (2010) e Campos (2008), apontam o desaparecimento de Oesterheld para o mês de abril de 1977, período histórico de ditadura militar na Argentina. Como consta no livro Oesterheld en tercera persona (2008), o roteirista foi levado para diferentes locais onde ficavam os presos políticos, tendo sido torturado e, mesmo assim, não dando maiores informações sobre 
seus colegas militantes de esquerda. Foi morto, provavelmente, no início de 1978, de acordo com Campos (2008). 


\section{EL ETERNAUTA: UMA ANÁLISE POLÍTICA E SOCIAL}

\subsection{Contexto da produção de El Eternauta e El Eternauta II}

Como consta no livro Oesterheld en tercera persona (2008) e também nas introduções das edições brasileiras das graphic novels O Eternauta (2011) e O Eternauta II (2013), a história em quadrinhos dos gêneros de aventura e de ficção científica El Eternauta, do roteirista Oesterheld, em conjunto com o desenhista Francisco Solano López, foi publicada, pela primeira vez, na segunda metade dos anos 1950, entre os anos de 1957 e 1959, pela revista argentina Hora Cero Suplemento Semanal, da editora Frontera. Buscando ser mais preciso: de acordo com Avila (2007), a publicação teve início em 04 de setembro de 1957 e foi concluída em 09 de setembro de 1959. A figura trinta e nove apresenta a capa do primeiro número da revista Hora Cero Suplemento Semanal.

Fig. 39 - Capa da revista Hora Cero Suplemento Semanal ( $\mathrm{n}^{\circ}$ 1).

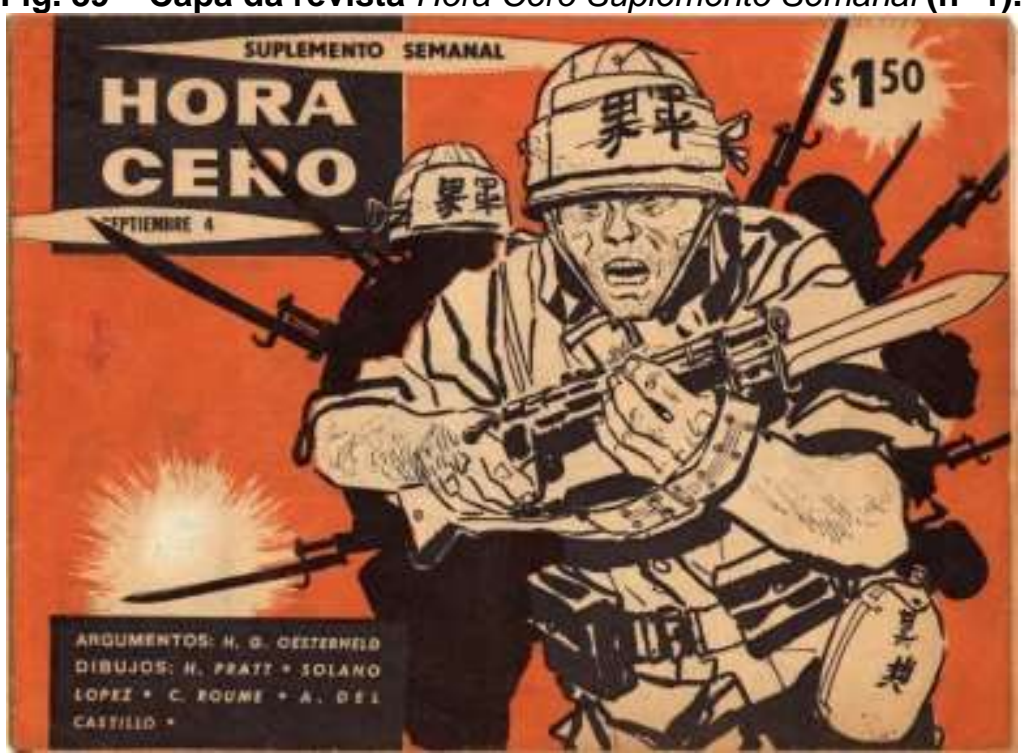

Fonte: figura cedida pelo colecionador e expositor Miguel Angel Foncueva.

Como já mencionado, El Eternauta possui uma sequência, El Eternauta II, também de Oesterheld e Solano López, que foi publicada, pela primeira vez, na segunda metade da década de 1970, entre os anos 1976 e 1978, na revista argentina Skorpio. 
Fora da Argentina, na Europa, El Eternauta foi publicada na Espanha, pela primeira vez, pela editora El Globo, em 1973. Posteriormente, essa obra estreou na Itália em 1977, pela editora Lanciostory, com o título de L'Eternauta.

No México, El Eternauta foi publicada, pela primeira vez, pela editoral RM, no início de 2011, enquanto que, no Brasil, os dois volumes de O Eternauta e O Eternauta II foram publicados, respectivamente, em 2011 e 2013, pela editora Martins Fontes.

E, mais recentemente, uma tradução para a língua inglesa, publicada pela editora Fantagraphics em 2015, ganhou o Eisner Awards (Prêmio Will Eisner) - 2016, a principal premiação na área de histórias em quadrinhos dos Estados Unidos, na categoria "melhor coleção de arquivo (tiras)".

Na Argentina, entre o período de publicação da história em quadrinhos El Eternauta (1957-1959) e o início da publicação do seu prolongamento El Eternauta II (1976), ocorreram diversos fatos na história desse país que demonstram significativa instabilidade política, após um longo período de desenvolvimento econômico e social que já ocorria desde a última década do século XIX - o que refletia (e reflete) tanto nas áreas da cultura e educação, como, também, no bem-estar da população em geral, com uma relativa valorização da classe trabalhadora.

Devido a essa instabilidade política, a Argentina teve onze presidentes durante o intervalo de tempo entre a publicação de El Eternauta e El Eternauta II, dois quais cinco foram depostos e um renunciou: Arturo Frondizi (19581962), José María Guido (1962-1963), Arturo Umberto Illia (1963-1966), general Juan Carlos Onganía (1966-1970), general Roberto Marcelo Levingston (1970-1971), general Alejandro Agustín Lanusse (1971-1973), Héctor José Cámpora (1973), Raúl Alberto Lastiri (1973), general Juan Domingo Perón (1973-1974), Maria Estela Martínez de Perón (1974-1976) e, por fim, o general Jorge Rafael Videla (1976-1981), como consta no site Presidencias en Argentina ${ }^{18}$.

${ }^{18}$ Disponível em: <https://www.sitiosargentina.com.ar/2/presidentes.htm>. Acesso em: 4 dez. 2018. 
Ainda naquele país, no final dos anos 1960, ocorre uma divisão no movimento peronista (grupo esse que, em linhas gerais, teve origem em 1945 e foi fortalecido no primeiro período do governo presidencial de Juan Domingo Perón, entre 4 de junho de 1946 até 21 de setembro de 1955, como é relatado no filme La Hora de los hornos: notas y testimonios sobre el colonialismo, la violencia y la liberación [200-]) - o qual, até então, tinha três princípios básicos, segundo Gillespie (1998) e como consta também no filme sul-americano La Hora de los hornos: notas y testimonios sobre el colonialismo, la violencia y la liberación [200-]: independência econômica, justiça social e soberania política -, com um deslocamento de um grupo nitidamente para a esquerda e outro, também de modo claro, para a direita, o que reflete a disputa entre diferentes grupos sociais no interior dessa sociedade e dos povos da América Latina em geral, refletindo também a Guerra Fria, num plano mais amplo.

E é justamente nesse momento histórico que ocorreu, como já mencionado anteriormente, o cordobazo, no final de maio de 1969. E, além disso, começaram a ocorrer ações armadas de grupos de esquerda na Argentina, principalmente de duas organizações: do não-peronista Ejército Revolucionário del Pueblo (ERP), que, de acordo com Gillespie (1998), tinha origem trotskista e que ao longo da década de 1970 tornou-se guevarista, e do grupo peronista Montoneros.

Esse último grupo político-miliar, os Montoneros, contou com a participação ativa de Héctor Germán Oesterheld e suas quatro filhas, nos últimos momentos de suas vidas. Buscando ser mais preciso em relação às origens deste último grupo:

Os Montoneros surgiram na cena política argentina durante alguns dos anos mais turbulentos, em termos de conflitos sociais, experimentados por seu país. Após a sua fundação, dois anos depois que o general Juan Carlos Onganía e as forças armadas usurparam o poder, em 1966, os fundadores dedicaram um par de anos ao treinamento preparatório e a acumular recursos antes de anunciar sua existência ao mundo em maio de 1970. Se sabe menos da fase de 1968-1970 que de qualquer outro período da história dos Montoneros, embora aqueles anos de anonimato, como aqueles que precederam imediatamente, foram de importância fundamental para 
determinar a fisionomia política de sua organização. (GILLESPIE, 1998, p. 73, tradução nossa) ${ }^{19}$.

Em artigo para a revista Astrolabio, do Centro de Investigações e Estudos sobre Cultura e Sociedade da Universidade Nacional de Córdoba, Von Sprecher (2007), também menciona que a aparição pública dos Montoneros ocorreu em maio de 1970, no dia 29. O núcleo fundador dos Montoneros era formado por: Carlos Capuano Martínez, Carlos Gustavo Ramus, Esther Norma Arrostito, Emilio Ángel Maza, Fernando Abal Medina, José Sabino Navarro e Mario Eduardo Firmenich.

Todos esses membros iniciais desse grupo político morreram ao longo dos anos 1970, exceto Firmenich (que até o momento em que esta tese foi escrita, permanece vivo), pois ficou exilado no exterior durante parte significativa do período da ditadura de Videla, permanecendo durante um período na Itália, posteriormente México e, por fim, em Cuba, passando um período também na Nicarágua, durante o governo sandinista. Firmenich ocupou o posto de secretário geral dos Montoneros entre 1971 e os anos 1980.

Posteriormente, como afirma Coggiola (2001) e Montero (2013), em 1973 começa a atuar no cenário político argentino a Aliança Anticomunista Argentina (AAA), grupo responsável por diferentes atos de violência política, como atentados, desaparecimentos e assassinatos políticos. Gillespie (1998) chega a afirmar que esse grupo contava com a proteção do Estado.

Desse modo, entre o final da década de 1960 e toda a década de 1970, ocorreu um clima de tensão social e política, com seguidas greves, a ocorrência de diversos protestos, além de mortes por motivos políticos, que explicitavam um confronto de visões de mundo significativamente diferentes entre os diversos grupos societários daquele país.

\footnotetext{
${ }^{19}$ Los Montoneros aparecieron en la escena política argentina durante algunos de los años más turbulentos, encuanto a conflictos sociales, experimentados por su país. Tras su fundación dos años después de que el general Juan Carlos Onganía y las fuerzas armadas usurparan el poder, en 1966, los fundadores dedicaron um par de años al entrenamiento preparatorio y a acumular recursos antes de anunciar su existencia al mundo em mayo de 1970. Se sabe menos de la fase de 1968-1970 que de cualquier otro período de la historia de los Montoneros, aun cuando aquellos años de anonimato, como los que les precedieron imediatamente, fueron de importancia fundamental para determinar la fisonomía política de su organización.
} 
Assim, como se vê, é no momento histórico de maiores conflitos entre classes sociais e uma tensão política muito intensa, que ocorre a produção da história em quadrinhos El Eternauta II, justamente durante a ditadura militar do general Videla, iniciada em 24 de maço de 1976, período também conhecido como a "guerra suja", em função das seguidas violações aos direitos humanos em todo o território do país, com a existência da repressão política sistemática aos socialistas, o cerceamento dos direitos civis, os desaparecimentos, os sequestros e os assassinatos em massa. Ou seja, existia um contexto que pode ser nomeado como o do "terror em massa" e do terrorismo de Estado, num cenário de resistência armada de parte da sociedade civil em relação à ditadura militar.

Para termos uma ideia da mentalidade reinante na época, pode-se mencionar a frase do general Ibérico Saint Jean, governador da província de Buenos Aires, nomeado por uma junta militar, durante o período de terrorismo de Estado da ditadura do general Videla: "Primeiro mataremos os subversivos, depois seus colaboradores e então os que continuam indiferentes, até, finalmente, matarmos os tímidos". (CAMPOS, 2008, p. 91). Tal mentalidade guarda fortes relações com o totalitarismo, pois:

Os movimentos totalitários são organizações maciças de indivíduos atomizados e isolados. Distinguem-se dos outros partidos e movimentos pela exigência de lealdade total, irrestrita, incondicional e inalterável de cada membro individual. Essa exigência é feita pelos líderes dos movimentos totalitários mesmo antes de tomarem o poder e decorre da alegação, já contida em sua ideologia, de que a organização abrangerá, no devido tempo, toda a raça humana. (ARENDT, 1989, p. 373).

Lembra-se, com isso, que uma das principais características do totalitarismo é justamente a busca por uma uniformidade inteiramente homogênea em termos de pensamento dos atores sociais. Desse modo, essa mentalidade e prática totalitária, que visam a destruição da condição humana, ocorrem, por meio, por exemplo, dos campos de concentração e de extermínio, os quais ocorreram, de modo sistemático, em alguns países que sofreram com o fato histórico da ditadura militar, em especial, na Argentina e no Chile. 
Diante desse contexto histórico e do engajamento de Oesterheld na atividade política em seu país, é possível entender os quadrinhos El Eternauta como sendo uma obra que, até certo ponto, pode ser associada ao peronismo clássico, no sentido de estar um tanto quanto distante do capitalismo liberal e do marxismo. Já El Eternauta /l está mais próxima do pensamento socialista, pois cada vez mais Oesterheld vai se envolver com a prática política, na condição de militante de esquerda. Da mesma forma, é possível afirmar que tanto El Eternauta e El Eternauta I/ representam ciclos históricos diferentes da vida social e política argentina e latino-americana.

O próximo item deste capítulo (6.2) será dedicado à discussão de $E l$ Eternauta. Como a fonte para a exposição das ideias e o uso das imagens foi a publicação brasileira, intitulada $O$ Eternauta, para efeitos de padronização, o título dessa obra, nesse item, aparece grafado em português, exceto no subtítulo do capítulo, o que ocorrerá também no item posterior a esse (6.3).

\subsection{El Eternauta.}

Fig. 40 - Capa da história em quadrinhos O Eternauta.

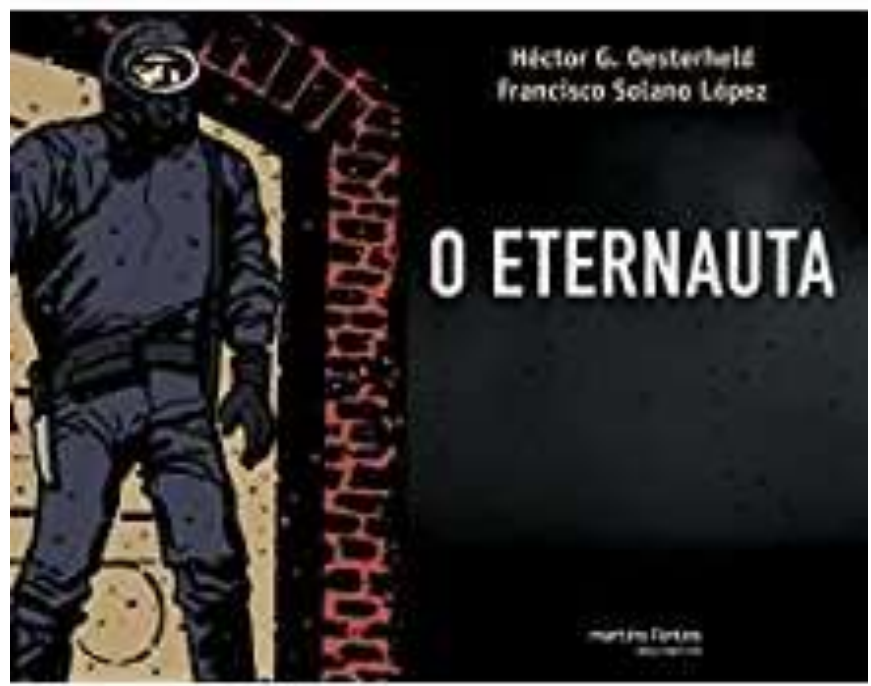

Fonte: acervo do autor. 
A história de $O$ Eternauta tem início quando quatro amigos se encontram para jogar cartas, na casa do protagonista Juan Salvo, situada na cidade de Buenos Aires. Os outros três personagens iniciais são: Favalli (um professor universitário da área de Física, que possui um discurso pessimista), Lucas (bancário) e Polsky (aposentado). Além desses, estão também presentes na casa de Juan Salvo sua esposa Elena e sua filha Martita.

Durante esse jogo de cartas, começa a nevar - fato incomum na cidade de Buenos Aires - e, além disso, logo é descoberto que ao menor contato com esses flocos de neve, ocorre uma morte praticamente instantânea. A névoa deixa, em um primeiro momento, os personagens isolados e presos dentro da casa de Juan Salvo, sem poder buscar ajuda, o que dá à história uma atmosfera opressiva e coloca os personagens, aparentemente, em um verdadeiro beco sem saída.

Posteriormente, no decorrer da história, aparecem outros personagens: Mosca (historiador), Pablo (funcionário de uma loja de ferragens) e Franco (operário, que se destaca pela sua iniciativa, podendo-se estabelecer paralelo inicial, desse modo, com uma forma de "resistência peronista"), entre outros. Juan Salvo (O Eternauta) é o narrador desta história.

O personagem Eternauta, apresentado, nesta tese, por meio da imagem quarenta e um, é aquele com maior proeminência ao longo desta história, lembrando-se, entretanto, que esse destaque do protagonista é bastante relativo, uma vez que Oesterheld, de um modo geral, dava uma maior ênfase no protagonismo grupal (e à solidariedade coletiva) nos roteiros de suas histórias em quadrinhos, o que inclui $O$ Eternauta. 
Fig. 41 - 0 personagem Eternauta.

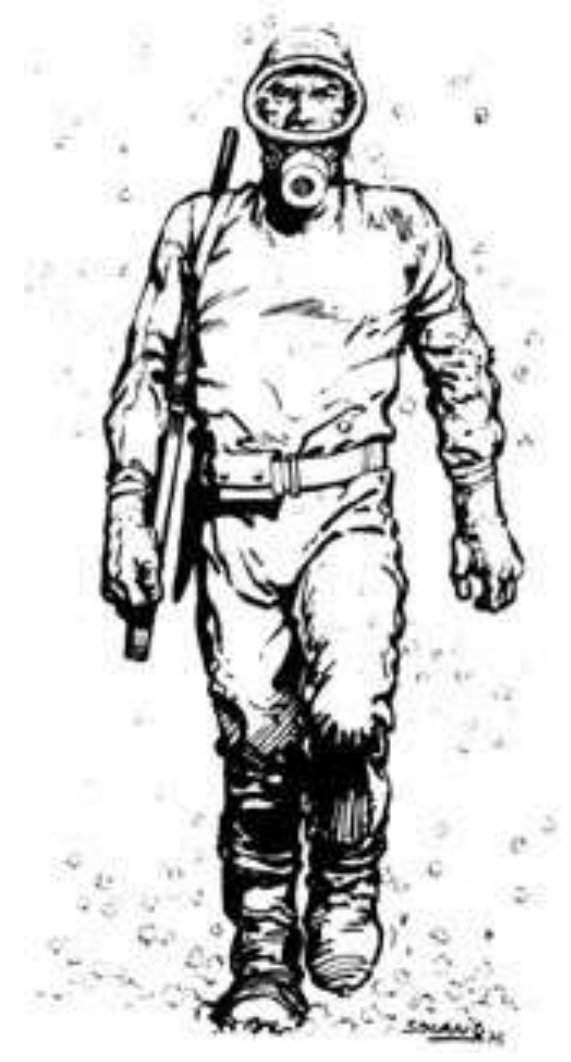

Fonte: Historieteca. Historieta argentina. Disponível em: <historieteca.com.ar/HGO/hgo.htm>. Acesso em: 20 nov. 2018.

A nevasca descrita anteriormente causa o aniquilamento de um número assombroso de vidas. Esse é apenas o primeiro sinal de uma invasão da Terra por seres de outros planetas. Tanto nos quadrinhos $O$ Eternauta como também na sua continuação O Eternauta II, os invasores são, em um primeiro momento, alguns insetos gigantes, denominados como Cascarudos (na versão em português, Cascudos, figura quarenta e dois), posteriormente os Gurbos (personagens que possuem os mesmos nomes nas versões em espanhol e também em português, figuras quarenta e três e quarenta e quatro) e, depois, os Manos (na versão em português, Mãos, figura quarenta e cinco). Todos esses comandados pelos Ellos (na versão em português, Eles). 
Fig. 42 - Os personagens Cascarudos (Cascudos) na obra O Eternauta.

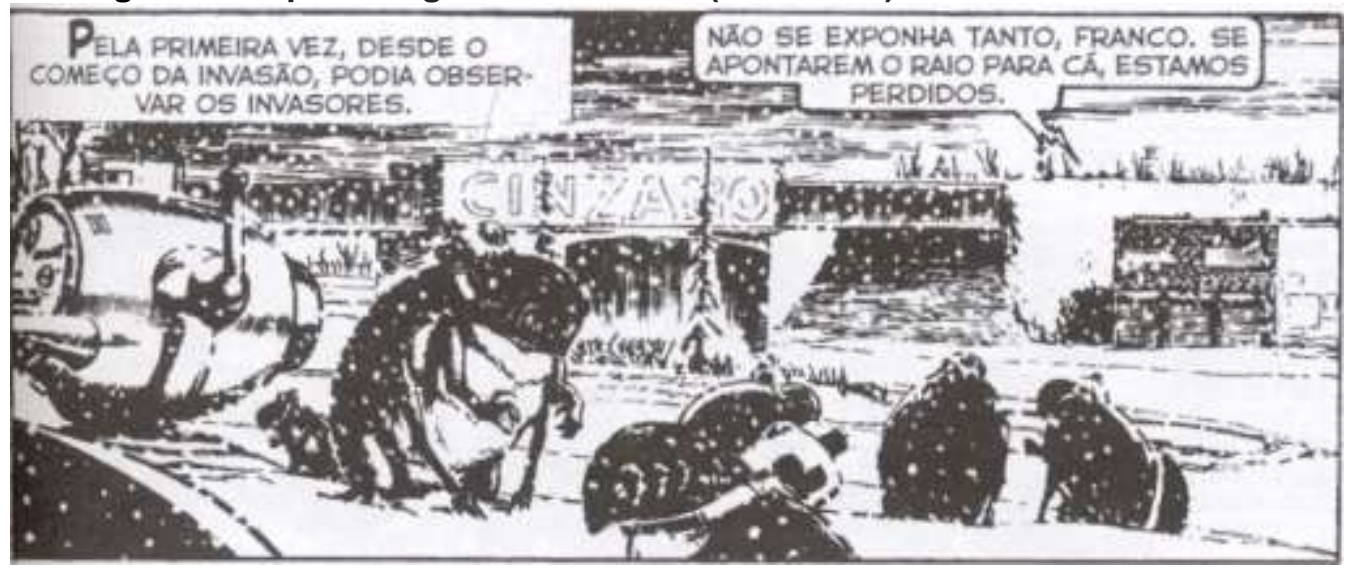

Fonte: acervo do autor.

Fig. 43 - Os personagens Gurbos na obra O Eternauta.

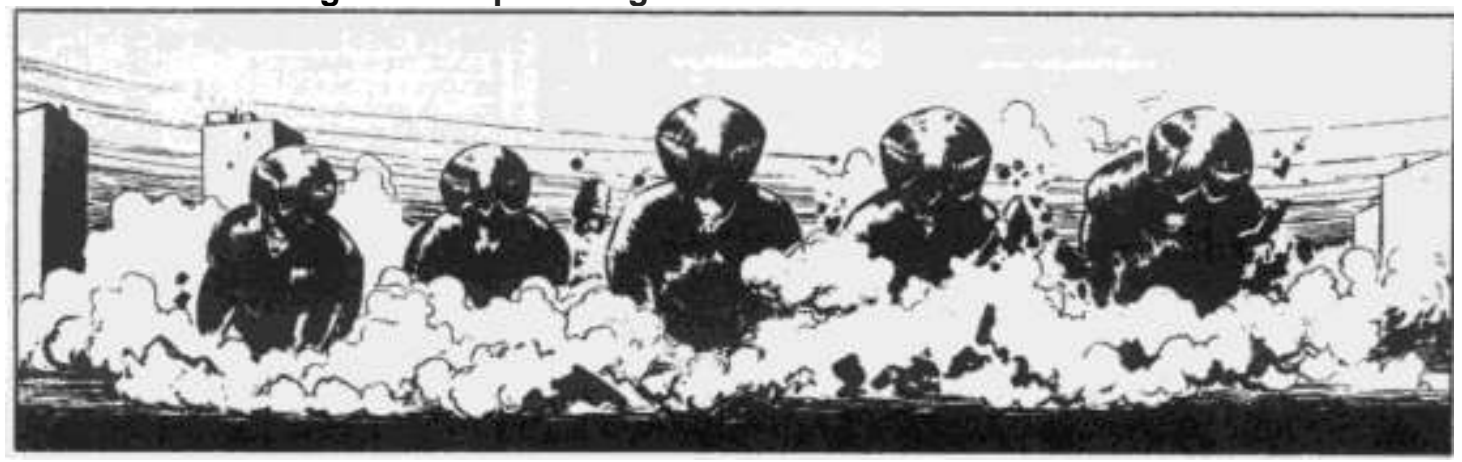

Fonte: acervo do autor.

Fig. 44 - Um personagem Gurbo em ação na obra O Eternauta.

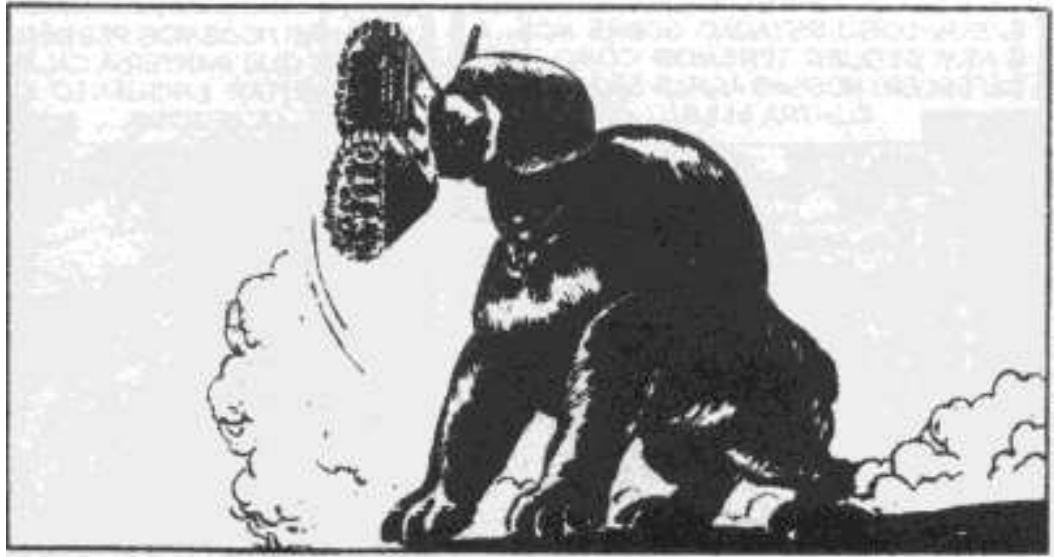

Fonte: acervo do autor. 
Fig. 45 - O personagem Mano (Mão) na obra O Eternauta.

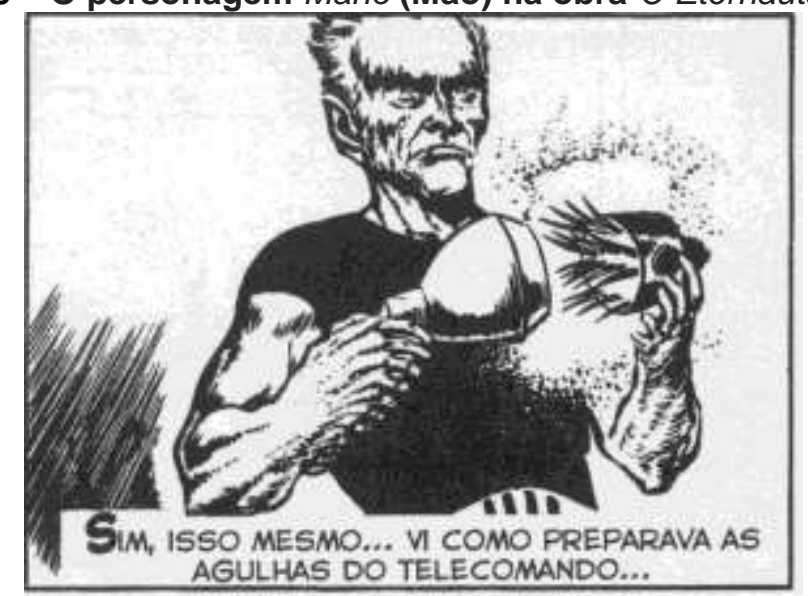

Fonte: acervo do autor.

Com relação aos personagens Ellos (Eles), existem várias leituras possíveis, mas é plausível relacionar os personagens Ellos com os franquistas, ou com os nazistas, ou mesmo com os estratos dominantes do capitalismo, ou seja, as classes burguesas, proprietárias dos meios relevantes de produção, pelo fato de que todos esses grupos sociais exercem relações de exploração, dos mais variados modos, em relação as outras camadas sociais, o que inclui, por exemplo, as classes sociais que vivem do trabalho (e não do capital). Nesse caso, os Ellos seriam os agentes do sistema.

Oesterheld, em seus roteiros, associa os Ellos com o ódio, um "ódio total", ou mesmo um "ódio universal", que na figura quarenta e seis é apresentado como o "ódio cósmico". Ou seja, um ódio dos membros dos grupos societários dominantes em relação a todos que buscam uma nova conformação social, na qual estaria, num primeiro plano, os seres humanos em conjunto, ou, dito em outros termos, toda a humanidade, onde todos, sem exceções, poderiam ter condições de se desenvolver artisticamente, culturalmente, esportivamente e intelectualmente. No entanto, todas essas possibilidades de desenvolvimento humano estão restritas, tanto historicamente como atualmente, para apenas algumas pessoas no interior desses estratos sociais dominantes. 
Fig. 46 - Um personagem Mano (Mão) falando sobre os personagens Ellos (Eles), na obra O Eternauta.

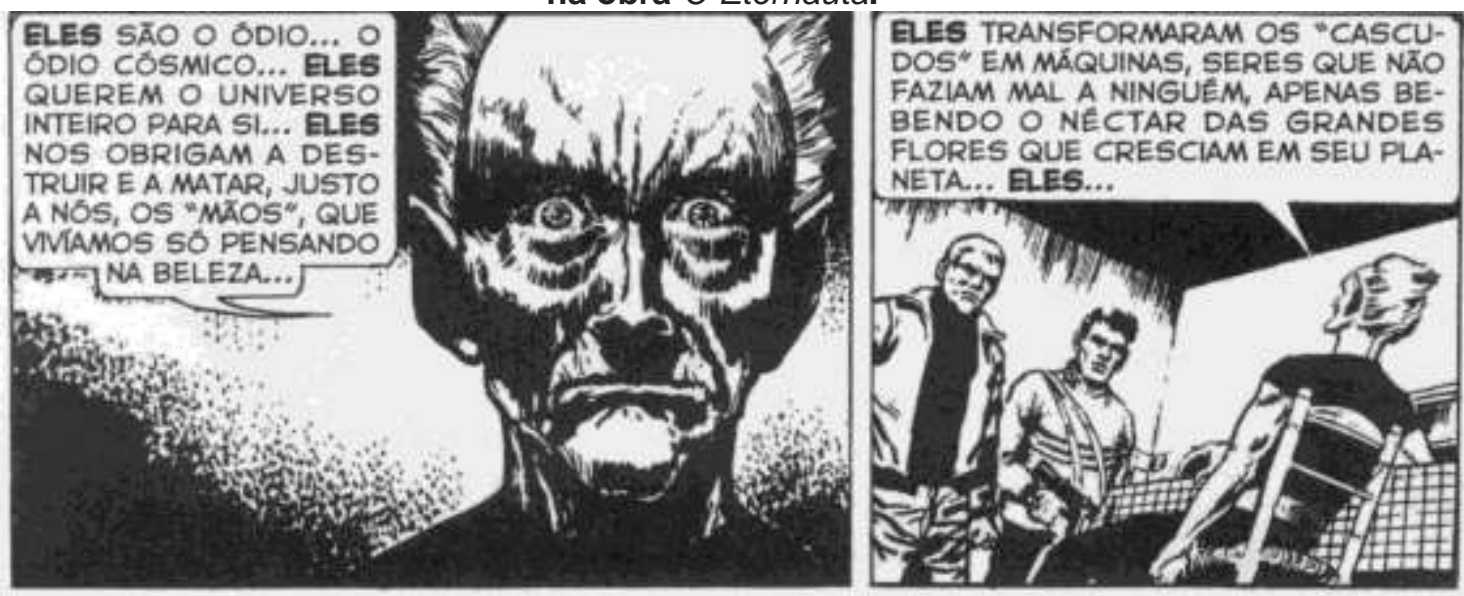

Fonte: acervo do autor.

Além do roteiro, os desenhos apresentam ao leitor uma atmosfera opressiva, com uma ambientação e paisagens desoladoras e realistas, bem representadas pelas imagens de Solano López.

Nesse contexto, os personagens permanecem rodeados pela morte, numa luta constante pela sobrevivência de um grupo de pessoas em meio a essa nevada mortal, que ocorre simultaneamente a uma invasão extraterrestre, pelos personagens mostrados anteriormente. Ou seja, é possível mencionar que existe uma resistência da sociedade civil, por parte de milicianos, que lutam pela libertação dessa ascendência alienígena sobre a Terra. A partir disso, Oesterheld trata do tema da amizade e da solidariedade entre os indivíduos no interior de um grupo social.

No decorrer da história, o personagem Juan Salvo entra com sua esposa e sua filha em um aparelho que os leva ao espaço e, também, a um outro tempo. A partir desse momento, ele é separado tanto de sua esposa Elena como da sua filha Martita. Ele inicia, então, uma busca por elas, em diversos espaços e tempos. Juan Salvo torna-se, assim, um personagem que fica perdido na eternidade - o Eternauta -, um navegante do tempo, ou, dito de outro modo, um viajante da eternidade que peregrina pelos séculos, que no final da história consegue regressar a sua casa, com sua esposa e filha, esquecendo-se do ocorrido. Desse modo, é possível perceber a narrativa de $O$ Eternauta como circular, pois no seu final ocorre uma volta a seu início. 
Ainda em relação ao trabalho de Oesterheld com os personagens dessa história em quadrinhos, é importante ressaltar que o roteiro dessa obra é inovador para a época, pelo fato de tratá-los de modo mais complexo, ao apresentar aos leitores, por exemplo, os sentimentos desses personagens, abandonando, desse modo, uma divisão clássica dos quadrinhos: "heróis" versus "vilões", muito comum, em linhas gerais, nas histórias em quadrinhos do Batman, Homem-Aranha e Super-Homem.

É fácil perceber que a obra tem como temáticas principais a escalada armamentista num cenário da existência de um potencial risco de uma guerra nuclear e sua consequente poluição atômica. Nesse sentido, é importante ressaltar o momento histórico da produção dessa história em quadrinhos, com início em 1957, apenas doze anos após o lançamento de duas bombas atômicas, por parte dos Estados Unidos, sobre as cidades de Hiroshima e Nagasaki, no Japão, além de seguidos testes de armas nucleares ao longo da década de 1950, realizados pelas grandes potências mundiais. Nas figuras quarenta e sete, quarenta e oito e quarenta e nove, pode-se ver três quadrinhos de $O$ Eternauta, publicados originalmente em apenas uma tira, a primeira da página quinze, nos quais é evidenciada a relação da narrativa textual e sua relação com a temática do perigo atômico, especialmente presente no discurso pacifista de Oesterheld, colocado nas vozes dos diversos personagens.

Fig. 47 - Informe sobre uma explosão atômica em O Eternauta (quadrinho um da tira).

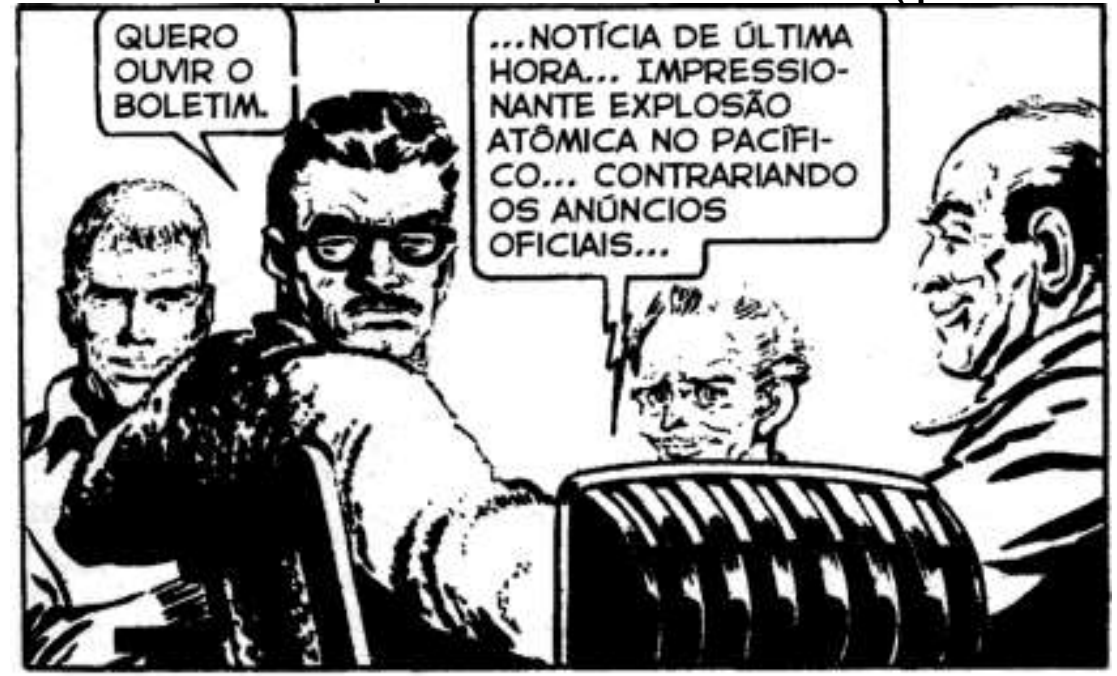

Fonte: acervo do autor. 
Fig. 48 - Informe sobre uma explosão atômica em O Eternauta (quadrinho dois da tira).

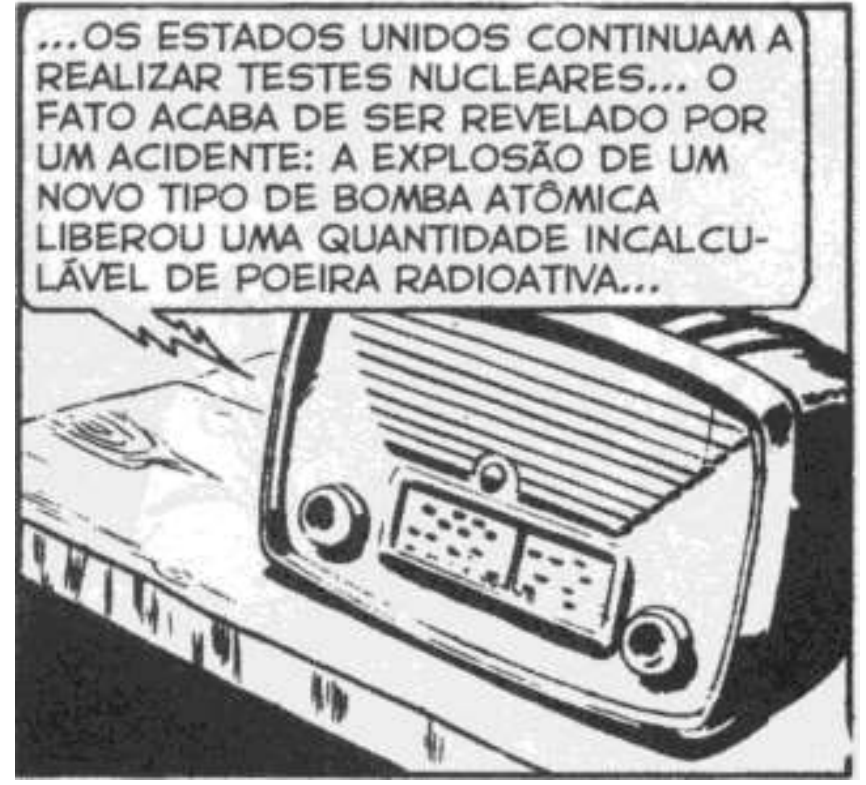

Fonte: acervo do autor.

Fig. 49 - Informe sobre uma explosão atômica em O Eternauta (quadrinho três da tira).

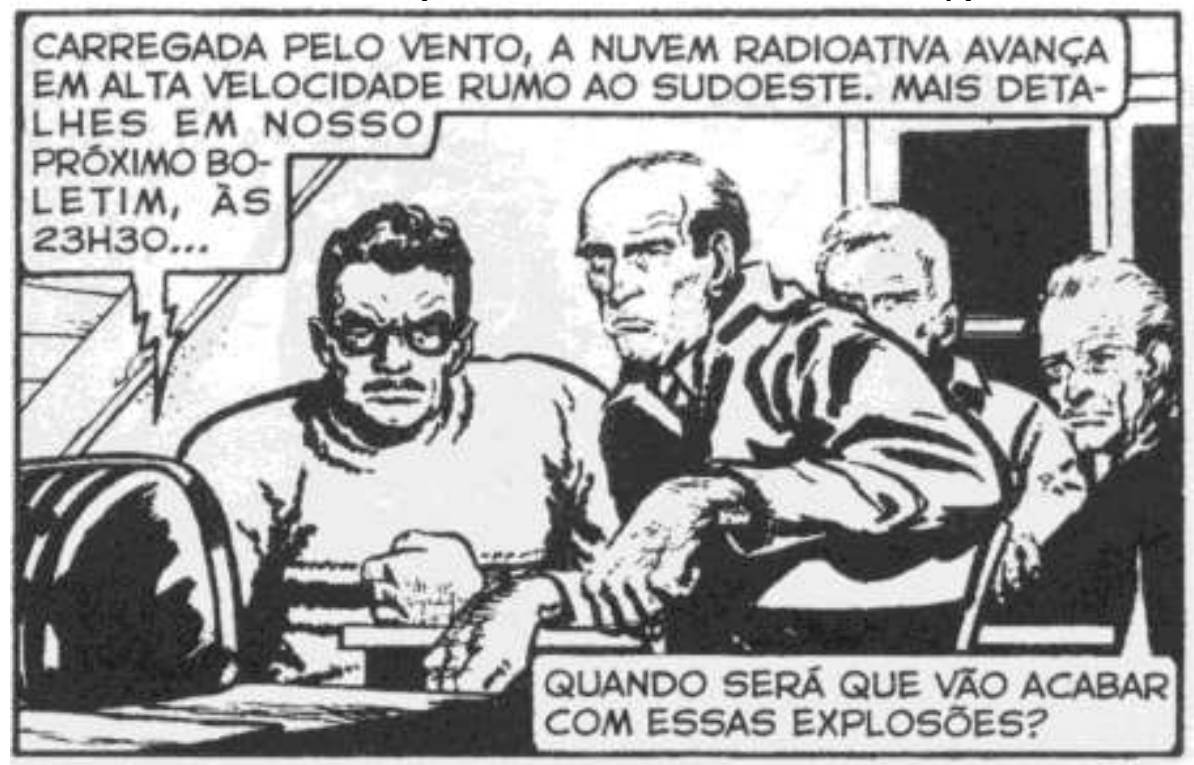

Fonte: acervo do autor.

O Eternauta também trata da luta pela sobrevivência dos seres humanos em um cenário de resistência à opressão política por meio de uma luta coletiva, dando ênfase, desse modo, ao protagonismo grupal e à solidariedade, expondo ao leitor uma visão crítica acerca dos valores da sociedade contemporânea. Como exemplo, na figura cinquenta, pode-se ver, na fala do 
personagem Mano (Mão), a menção à possível existência de "um sentimento de solidariedade por todos os outros humanos".

Fig. 50 - A importância do tema da solidariedade na narrativa de $O$ Eternauta.

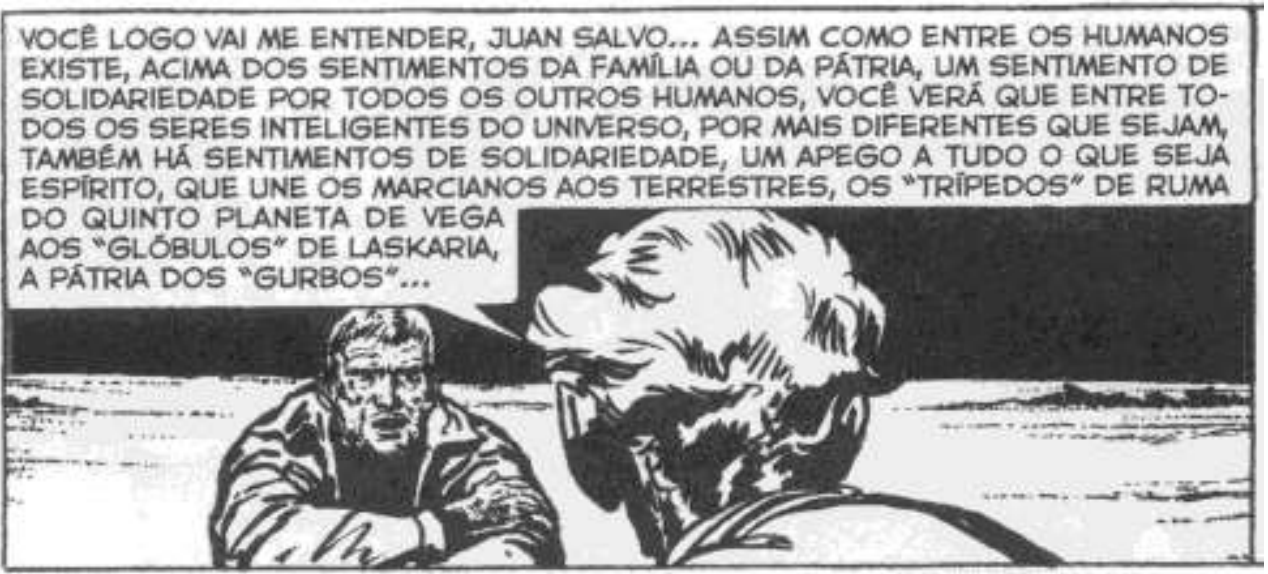

Fonte: acervo do autor.

Portanto, considerando o contexto mundial da época, é possível entender O Eternauta como sendo uma contundente denúncia que Oesterheld apresenta ao leitor em relação aos processos de crescente tensão no planeta, em função dessa corrida armamentista, e uma crítica das mais relevantes ao perigo nuclear em todo o planeta. Com isso, Oesterheld atua favoravelmente pelo fim da fabricação (e, consequentemente, do uso) dos armamentos nucleares.

Desse modo, é possível entender a obra O Eternauta como da maior importância para estudos que analisem o modo como os grupos societários pensam, reagem e se comportam quando expostos a alguma situação-limite que envolva conflitos sociais.

Como exemplo possível desse contexto, pode-se mencionar o tema do sacrifício em nome de uma causa maior (pelo fim de um regime opressor e/ou ditatorial, por exemplo), no qual os indivíduos perdem uma carreira profissional estável e bem remunerada em função do preconceito que sofrem por opções políticas, ou, até mesmo, deixam de ter a própria vida, pelo resultado da repressão a que são submetidos.

O próximo item deste capítulo será dedicado à discussão de El Eternauta II. Como a fonte para a análise e discussão do conteúdo visual e textual foi a 
versão brasileira da obra, intitulada $O$ Eternauta II, para efeitos de padronização, neste próximo item, o título dessa história em quadrinhos aparece grafado em português, exceto no subtítulo do capítulo.

\subsection{El Eternauta II}

Fig. 51 - Capa da história em quadrinhos O Eternauta II.

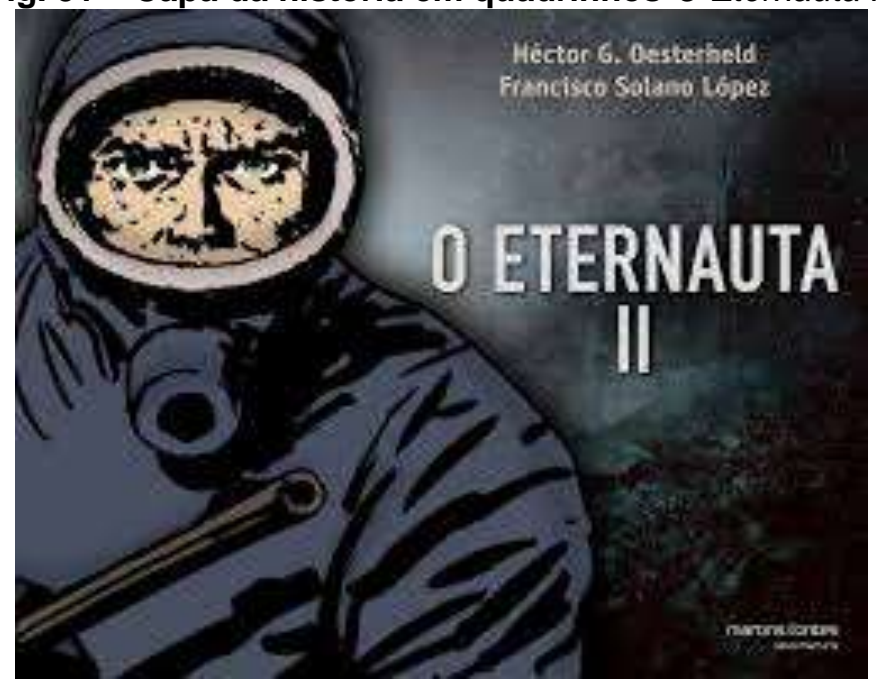

Fonte: acervo do autor.

No prolongamento da história, em O Eternauta II, o leitor é exposto novamente à temática da resistência de membros da sociedade civil em relação aos invasores extraterrestres, esses últimos sendo, naquele momento histórico, possivelmente, uma metáfora aos militares argentinos.

As figuras cinquenta e dois e cinquenta e três mostram tanto os invasores do planeta Terra mencionados anteriormente - Cascarudos, Gurbos e Manos -, em sua primeira tira, como também a importância dos anos 1959, 1963, 1970 e 1973 para as narrativas de O Eternauta e O Eternauta II, em sua segunda tira. 
Fig. 52 - Recordações da luta pela sobrevivência dos membros da sociedade civil na obra O Eternauta II.

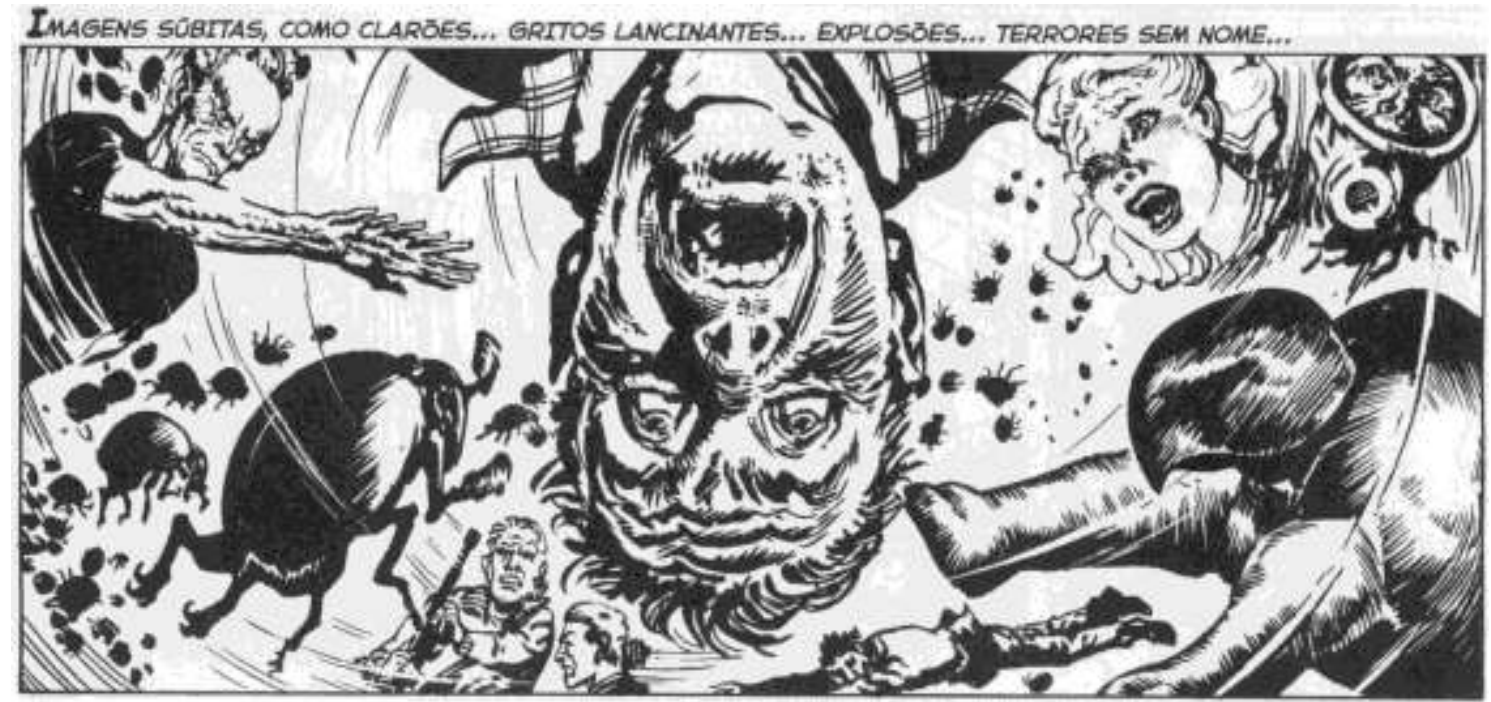

Fonte: acervo do autor.

Fig. 53 - Recordações do período compreendido entre 1959 e 1976 na narrativa da obra O Eternauta II.
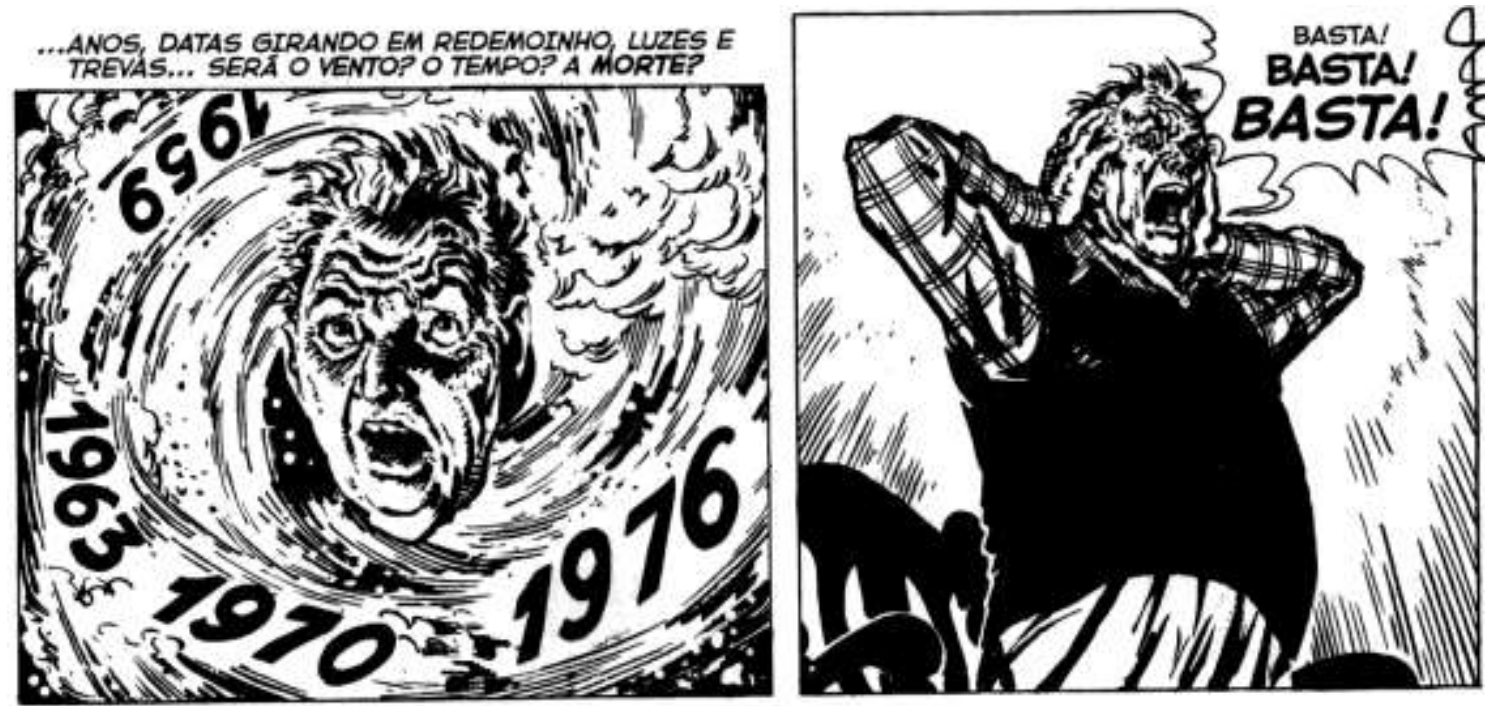

Fonte: acervo do autor.

Vale ressaltar que 1959 marca o fim da publicação de O Eternauta, além de ser o ano da Revolução Cubana, fato que teve impacto relevante em toda a América Latina, em função de, pela primeira vez, um país dessa região sair da esfera de influência dos Estados Unidos para uma aproximação com a (extinta) União Soviética, o que teve repercussão em vários países, com 0 fortalecimento de grupos de esquerda em várias dessas nações. 
Em 1963 ocorre tanto o fim do governo de José Maria Guido, como também o início da presidência de Arturo Umberto Illia, na Argentina.

Em 1970 ocorre o anúncio oficial da existência dos Montoneros e a execução do general Pedro Eugenio Aramburu, presidente da Argentina entre os anos de 1955 e 1958, por este grupo. Essa organização político-militar chegou a ter, nos anos 1970, a capacidade de mobilizar politicamente dezenas de milhares de pessoas, como lembra Gillespie (1998).

Já 1976 marca o início da publicação dos quadrinhos Eternauta II, pela editora Record, mesmo ano que ocorre o fim do governo de Maria Estela Martínez de Perón e o golpe militar que coloca o general Videla como presidente argentino e, consequentemente, o início do terrorismo de Estado na Argentina, com o exílio político de milhares de argentinos que acabaram se deslocando para outros países, fugindo de um contexto que se aproximava a de uma guerra política do Estado contra uma parcela da sociedade civil, que estava organizada na resistência ao terrorismo de Estado.

Tal contexto expressa uma situação de guerra real na Argentina (e na América Latina como um todo), envolvendo diferentes classes sociais, acerca da distribuição dos recursos materiais, dos diferentes ideários políticos e também das diversas narrativas sobre a História e sobre o contexto cultural, político e social daquele momento, tendo como cenário uma explicitação dos conflitos de classes sociais existentes do modo de produção capitalista, com a dominação de um estrato social (proprietários dos meios relevantes de produção) sobre outro (classes que vivem do trabalho).

Os grupos sociais distintos são apresentados em conflito constante e intenso, fazendo alusões a um ambiente de guerra, num cenário social em que as classes que vivem do trabalho estão vivendo em condições sub-humanas, pois essas pessoas, em O Eternauta II, tornaram-se habitantes de cavernas, chamado de el pueblo de las cuevas, que na tradução brasileira aparece como o "povo das cavernas", que são submetidos pelos personagens zarpos, que aparecem na tradução brasileira denominados como "garras". 
Uma leitura possível é a de que "o povo das cavernas" cumpriria uma função simbólica de representar os familiares dos militantes socialistas assassinados durante o regime militar argentino. Esse grupo, com o auxílio dos demais membros da sociedade civil - semelhantemente àqueles que resistiam à ditadura militar -, buscavam se opor à dominação dos invasores extraterrestres, que exerciam opressão política em relação aos demais estratos sociais, esses últimos apresentados ao leitor em situação de extrema pobreza, sendo esses os membros das classes que vivem do trabalho.

Essa resistência da sociedade civil era feita, por vezes, de modo armado em relação aos invasores extraterrestres, pois essa oposição das classes que vivem do trabalho à ditadura militar (apoiada pelos capitalistas, detentores dos meios relevantes de produção) era realizada de modo precário. Afinal, ocorria com restrições dos mais diversos recursos (como armas e dinheiro, por exemplo, além de ser feita por pessoas que não possuíam um treinamento militar adequado), o que favorecia a repressão política dos estratos sociais dominantes.

Tal fato pode ser visualizada na figura cinquenta e quatro, que apresenta o discurso do opressor, nesse caso um personagem Mano (Mão), que exige a rendição (e também o silêncio) da resistência terrestre em relação à invasão dos alienígenas. Para tanto, o extraterrestre ameaça com o uso da violência, por meio das armas e dos combatentes. Ou seja, nesse quadrinho ocorre a exposição de uma forma de pensamento, de modo figurado, acerca de uma imposição autoritária que ocorre por meio de práticas que envolvem o terror e a violência política e social, práticas comuns em regimes opressivos. Assim, é possível afirmar que o contexto societário apresentado nesse quadrinho, por meio da fala do personagem Mano, guarda contundentes paralelos com um campo de batalha e de uma guerra política e social, envolvendo diferentes classes sociais, ideologias e visões de mundo, numa disputa pelo poder político (e simbólico). 
Fig. 54 - Fala de um personagem Mano (Mão).

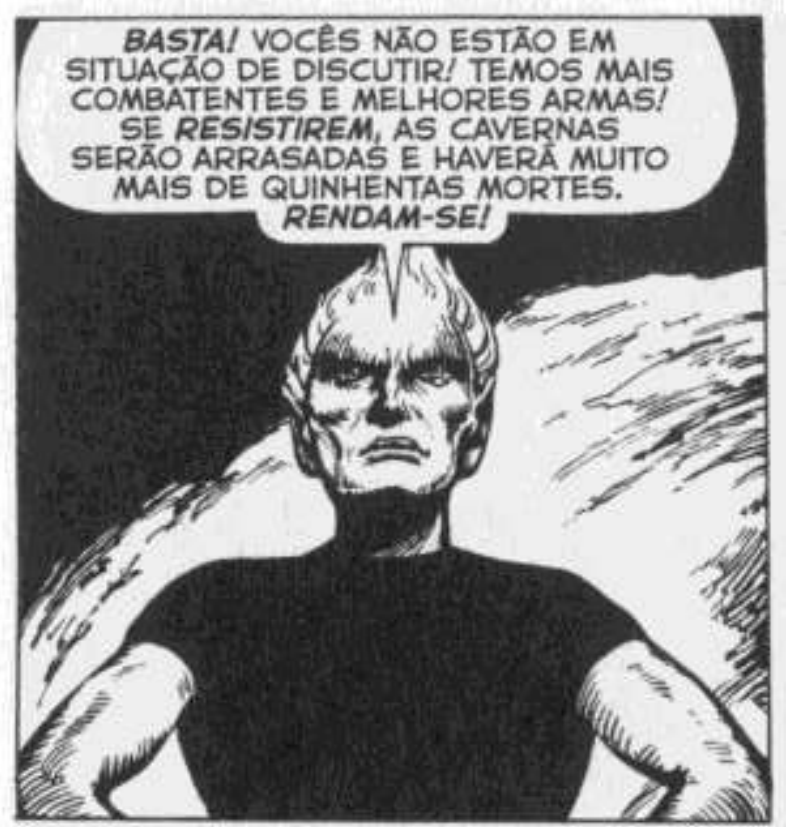

Fonte: acervo do autor.

Tal contexto remete a uma discussão sobre os direitos humanos, o que envolve a opressão política e também o terrorismo de Estado praticado durante o período em que a Argentina esteve sob a presidência do general Videla - e, posteriormente, também de outros generais -, e o papel da sociedade civil e o seu dever de resistência a este cenário político e social.

Um elemento singular e da maior importância da história em quadrinhos O Eternauta II é o fato de que "o povo das cavernas" assume o protagonismo da resistência política em relação ao opressor (nos quadrinhos, os invasores extraterrestres representam, num sentido alegórico, as forças militares do Estado argentino, naquele momento histórico). Tal fato retoma a noção de Oesterheld acerca da importância da construção social da "luta coletiva" e do "protagonismo coletivo" para a libertação das classes que vivem do trabalho (e não do capital). Isso demarca uma significativa diferença entre a produção quadrinística oesterheldiana em relação a alguns personagens clássicos das histórias em quadrinhos como o Batman, o Homem-Aranha, o Hulk, a Mulher Maravilha e o Super-Homem, todos esses caracterizados pelo seu mais profundo individualismo, o que expressa o estilo de vida no modo de produção capitalista. Dito de outro modo, o "protagonismo coletivo" presente nos 
quadrinhos de Oesterheld é uma contraposição ao herói individual, presente nos quadrinhos mainstream americanos, que possuem como característica a onipotência e a invencibilidade.

Como pode ser observado na figura cinquenta e cinco, na história $O$ Eternauta II, os estratos sociais mais empobrecidos estão morando em cavernas, o que retoma, por exemplo, a discussão dos problemas nas áreas da habitação e da saúde que afetam as classes que vivem do trabalho e ocorrem nas áreas urbanas de algumas das grandes cidades latinoamericanas. Nesse sentido, mais uma vez também é adequado ressaltar a importância da linguagem quadrinística, pelo uso da estética expressionista nessa figura, que apresenta ao leitor a miséria do povo, destruído (ou em vias de destruição) tanto da perspectiva econômica como social.

$\mathrm{E}$, além disso, como mencionado nos parágrafos anteriores, estão sendo submetidos por uma outra camada (classe) social, que faz uso tanto da opressão econômica e política:

Fig. 55 - As classes que vivem do trabalho, chamado "o povo das cavernas", na obra $O$ Eternauta II.
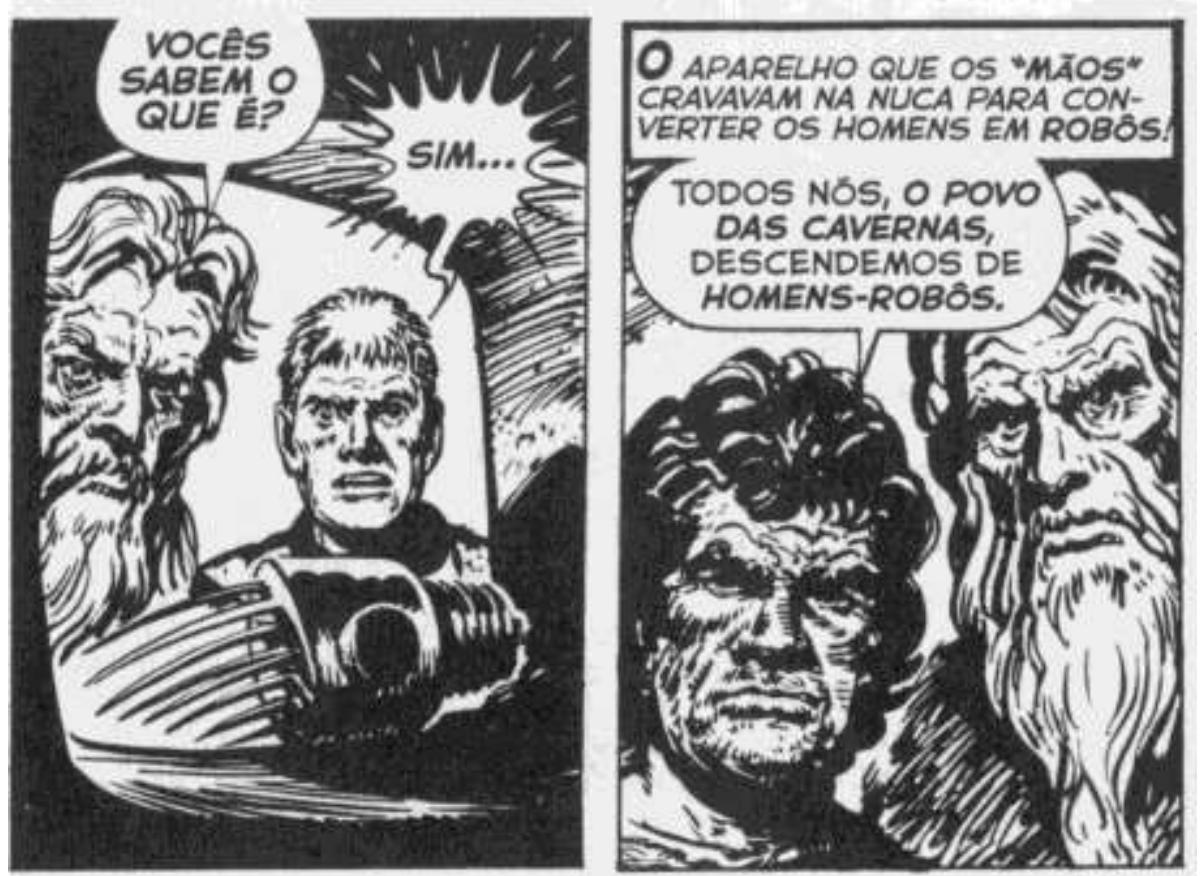

Fonte: acervo do autor. 
Desse modo, é possível dizer que O Eternauta ll é um prolongamento de $O$ Eternauta. Porém, possui um contexto e um roteiro mais focados nos temas políticos próprios da América Latina da época (os quais, por vezes, repercutem até os dias atuais em vários contextos sociais), sendo elaborado no período da ditadura militar argentina, quando o próprio roteirista estava na clandestinidade e tinha ligações políticas com os Montoneros, grupo políticomilitar armado de resistência à ditadura militar que lutava pela redemocratização e também pela implantação do socialismo na Argentina.

Em O Eternauta II, Oesterheld trata da pobreza de alguns estratos sociais da América Latina, das ditaduras militares neste sub-continente, incluindo sua prática de violência estatal sobre as classes que vivem do trabalho, além da resistência civil a essas ditaduras, por vezes recorrendo à resistência armada, fazendo alusões ao grupo Montoneros - de que o próprio Oesterheld fazia parte. Buscando contextualizar o momento histórico da produção de O Eternauta II, é possível dizer que:

As "novas" ditaduras militares surgidas na década de 1970, inclusive quando eram só a reformulação de ditaduras já existentes (como nos casos de Peru e Brasil), não se distinguiram apenas por um grau maior de brutalidade contra seus opositores do que as precedentes. Elas também correspondiam a uma situação histórica nova (...). Diferentemente das ditaduras da década de 1960, que possuíam um caráter mais "preventivo" de um eventual contágio da Revolução Cubana, as ditaduras da década de 1970 possuíam um caráter evidentemente contra-revolucionário. (COGGIOLA, 2001, p. 35).

$\mathrm{Na}$ figura cinquenta e seis é representado, metaforicamente, o conflito e a luta entre as diferentes classes sociais: as classes que vivem do trabalho (em termos marxistas, o proletariado) e os proprietários dos meios relevantes de produção (as burguesias). Nesse contexto, os donos do poder usam sistematicamente da violência contra as demais classes sociais. Desse modo, trata-se de uma referência explícita ao período histórico de ditadura militar e também do terrorismo de Estado, durante o período de governo do general Videla na Argentina. 
O objetivo do "povo das cavernas" é o da tomada do forte - que representa, num sentido alegórico, a "sede do mal", a sede dos interesses das classes dominantes (burguesas), o que retoma o cenário de luta entre as diferentes (e complementares) classes sociais no capitalismo: as classes sociais proprietárias e o proletariado, podendo significar, metaforicamente, a tomada do poder pelos trabalhadores (ou seja, pelos proletários), numa busca pelo fim do quadro atual de alienação cultural, econômica e política das classes que vivem do trabalho, em favor de uma ordem mais justa e solidária.

Tal contexto retoma, no contexto latino-americano, por exemplo, a vitória dos revolucionários cubanos, sob a direção de Fidel Castro e Ernesto "Che" Guevara, ou, num contexto mais amplo, a Revolução Russa, com a vitória dos bolcheviques. Além disso, também demonstra a riqueza dos recursos das histórias em quadrinhos, presente por vezes no gênero da ficção científica, ao expor uma modulação do tempo histórico, que nesse caso pode envolver, ao mesmo tempo, quatro momentos históricos diferentes: 1917 (Revolução Russa), 1949 (Revolução Chinesa), 1959 (Revolução Cubana) e também, entre 1976 e 1981 (Argentina durante o período da presidência do general Videla, no que se refere a uma disputa pelo poder político e os conflitos decorrentes desse fato).

Buscando ir mais além: as figuras cinquenta e seis e cinquenta e sete podem também apresentar ao leitor, como uma leitura plausível, três contextos diferentes, expressando um período de possível transformação social: um cenário político passado (representado pela desigualdade e opressão social, em uma realidade vivenciada pelas classes que vivem do trabalho na sociedade contemporânea capitalista, em relação à organização produtiva e também acerca da distribuição das mercadorias), um cenário político atual (uma maior consciência social que se expressa por uma luta pela tomada do poder, ou seja, uma realidade em transformação) e também um possível futuro (com o fim dessa tirania social). 
Fig. 56 - Exposição, de modo alegórico, do conflito entre as classes sociais na obra El Eternauta II ("o povo das cavernas" e "os garras").
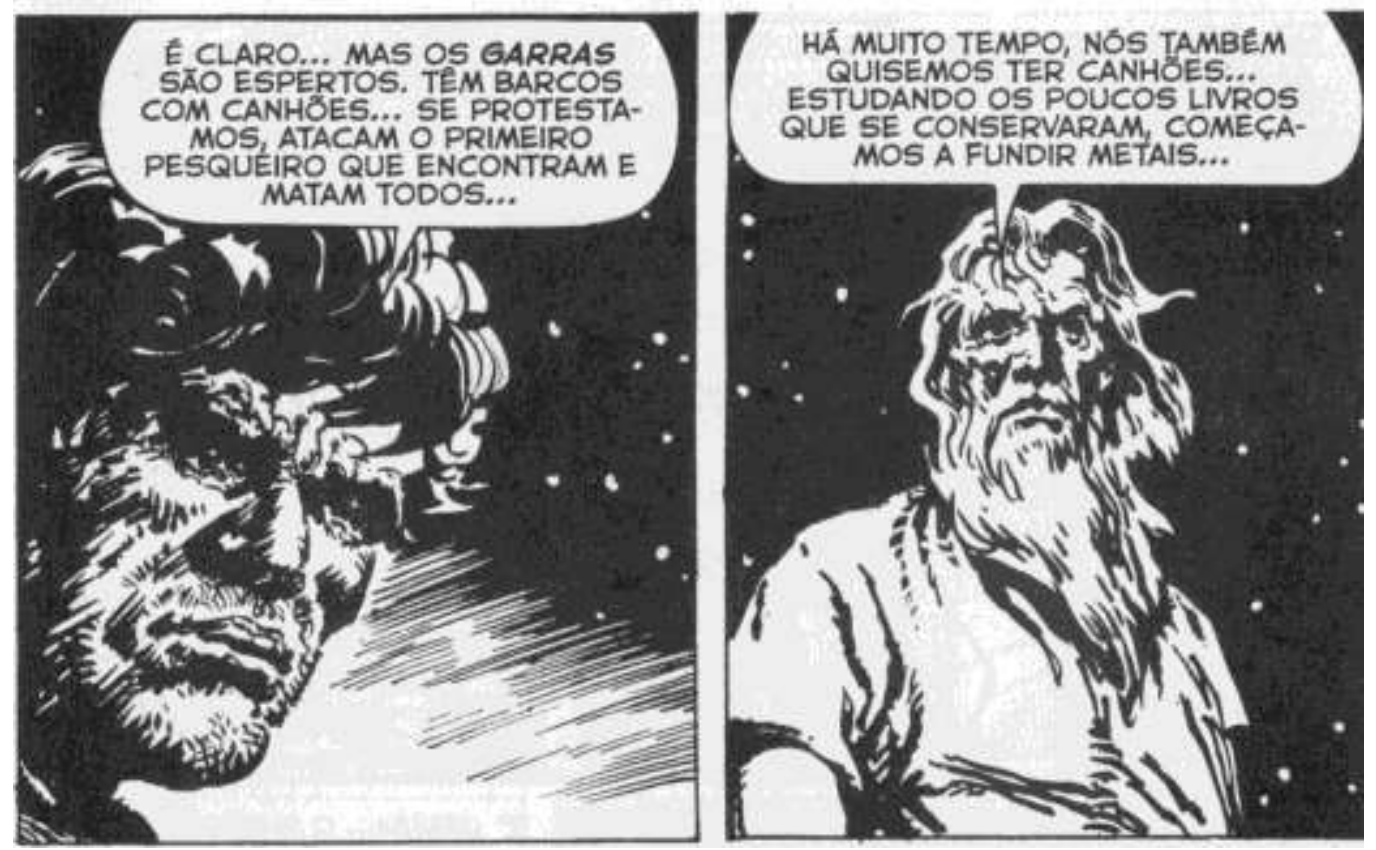

Fonte: acervo do autor.

Fig. 57 - Imagem, de modo alegórico, de uma sede de governo na obra O Eternauta II.

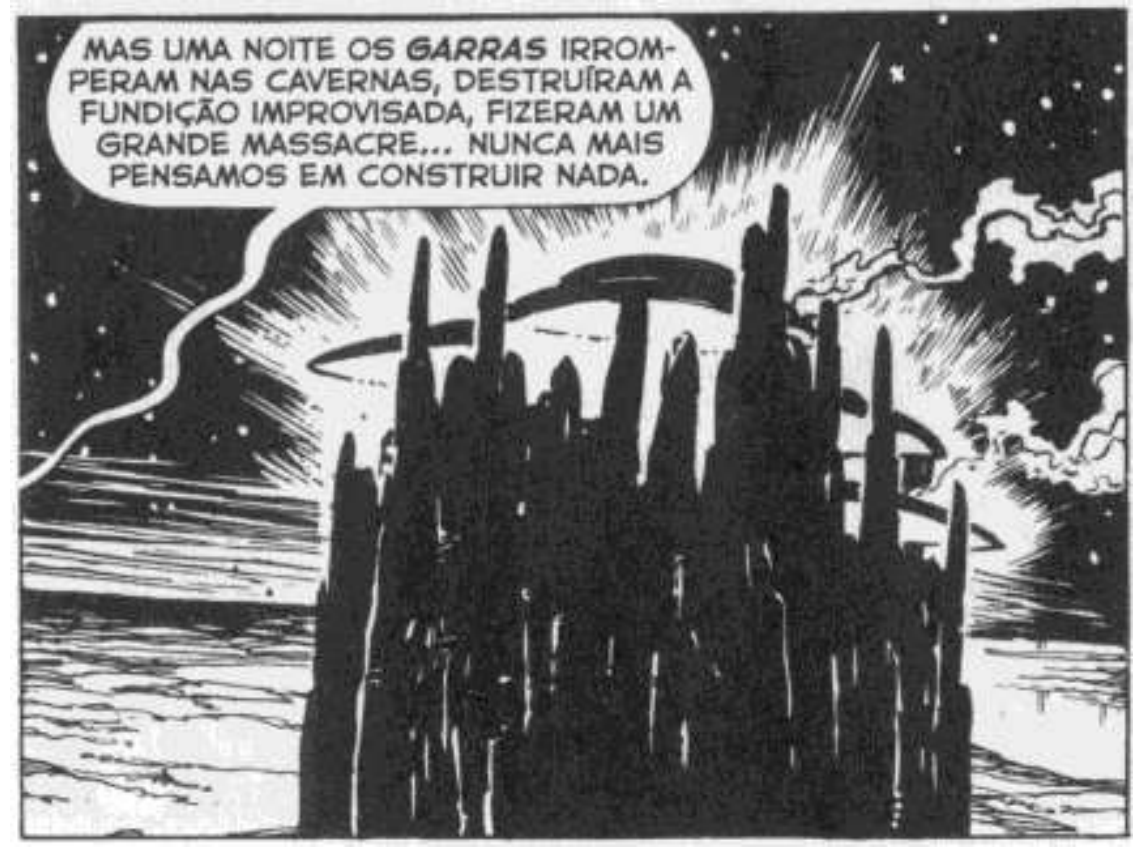

Fonte: acervo do autor.

Além disso, é necessário mencionar que alguns dos principais personagens de O Eternauta // podem ser entendidos como lideranças políticas socialistas: assim, Juan Salvo, por exemplo, numa intensa aproximação com a figura de "Che" Guevara, aparece como sendo uma liderança guerrilheira. 
É possível, também, associar as falas (e ações) de Juan Salvo com o de um membro do movimento político e social do peronismo de esquerda, ou seja, de um "peronismo revolucionário", pois apresenta um discurso, em O Eternauta II, muito próximo dos integrantes dos Montoneros, em defesa da resistência política à ditadura militar.

O mesmo ocorre com seu braço direito, Germán Oesterheld, presente explicitamente nos quadrinhos $O$ Eternauta II como um narrador e um personagem politicamente ativo. Tal fato marca uma passagem política importante entre El Eternauta e El Eternauta II: na primeira história, o personagem Oesterheld aparece, em linhas gerais, como um narrador da história e um ouvinte passivo desta, enquanto que na segunda história, como um militante político de esquerda.

As figuras cinquenta e oito e cinquenta e nove apresentam o personagem Oesterheld nas duas histórias em quadrinhos, nas quais, respectivamente vêse o narrador Oesterheld, em sua casa, observando a "materialização" do personagem Eternauta, e, já com a presença efetiva do personagem Eternauta, que se mostra consciente do tempo e do espaço em que está presente (ambas pertencem ao início da narrativa de O Eternauta).

Posteriormente, nas figuras sessenta e sessenta e um, Oesterheld aparece explicitamente, apresentando-se ao público leitor como Germán. Nesse sentido, é necessário ressaltar que "Germán" é, de acordo com Von Sprecher (2007), o seu nome de guerra no grupo político-militar Montoneros. E, na figura sessenta e dois, Germán (ao lado de Juan Salvo) participa de uma ação política específica. 
Fig. 58 - Oesterheld (à direita) observando a materialização do personagem Eternauta (à esquerda) em $O$ Eternauta.

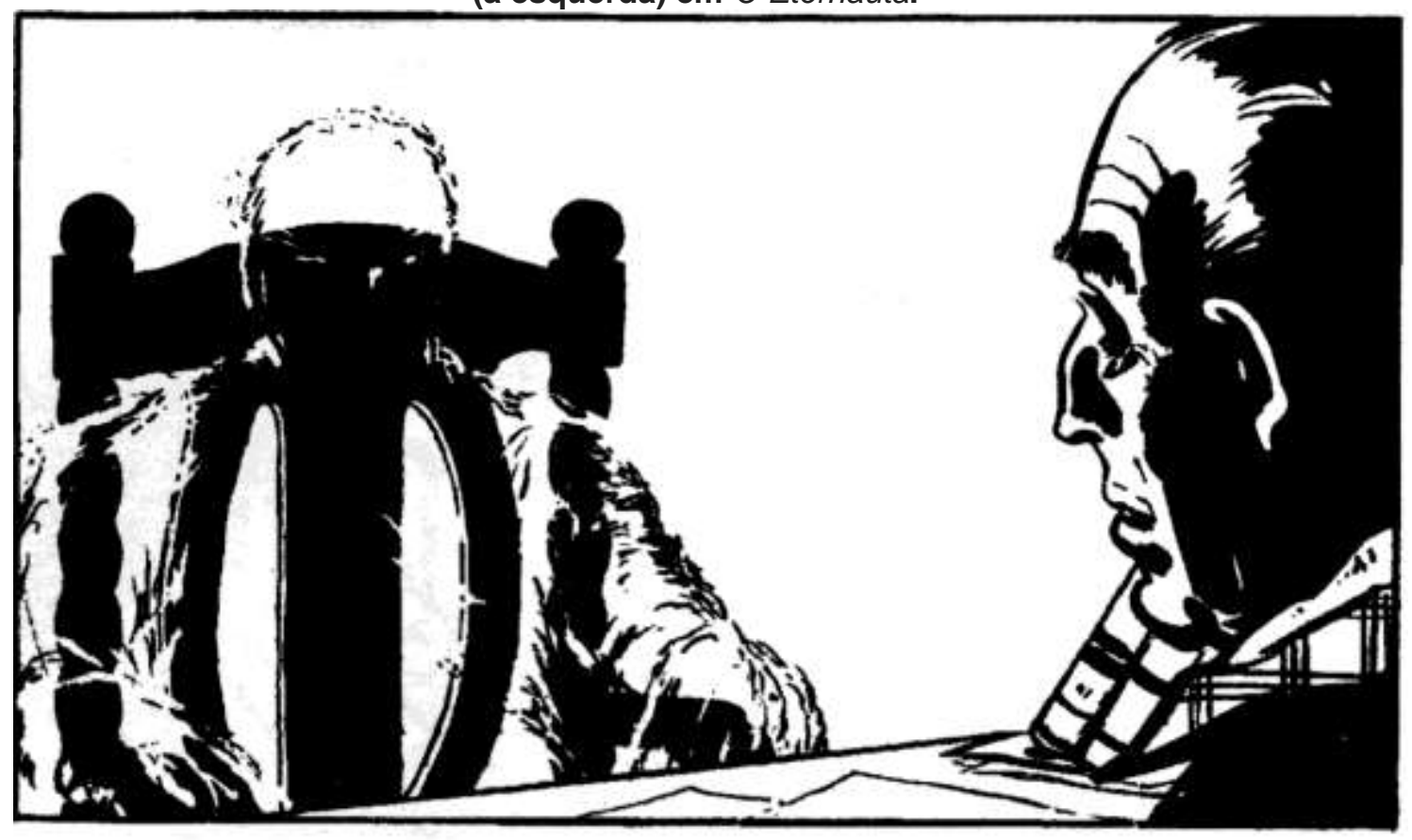

Fonte: acervo do autor.

Fig. 59 - Oesterheld (à esquerda) ouvindo o personagem Eternauta (à direita), após a sua materialização em $O$ Eternauta.

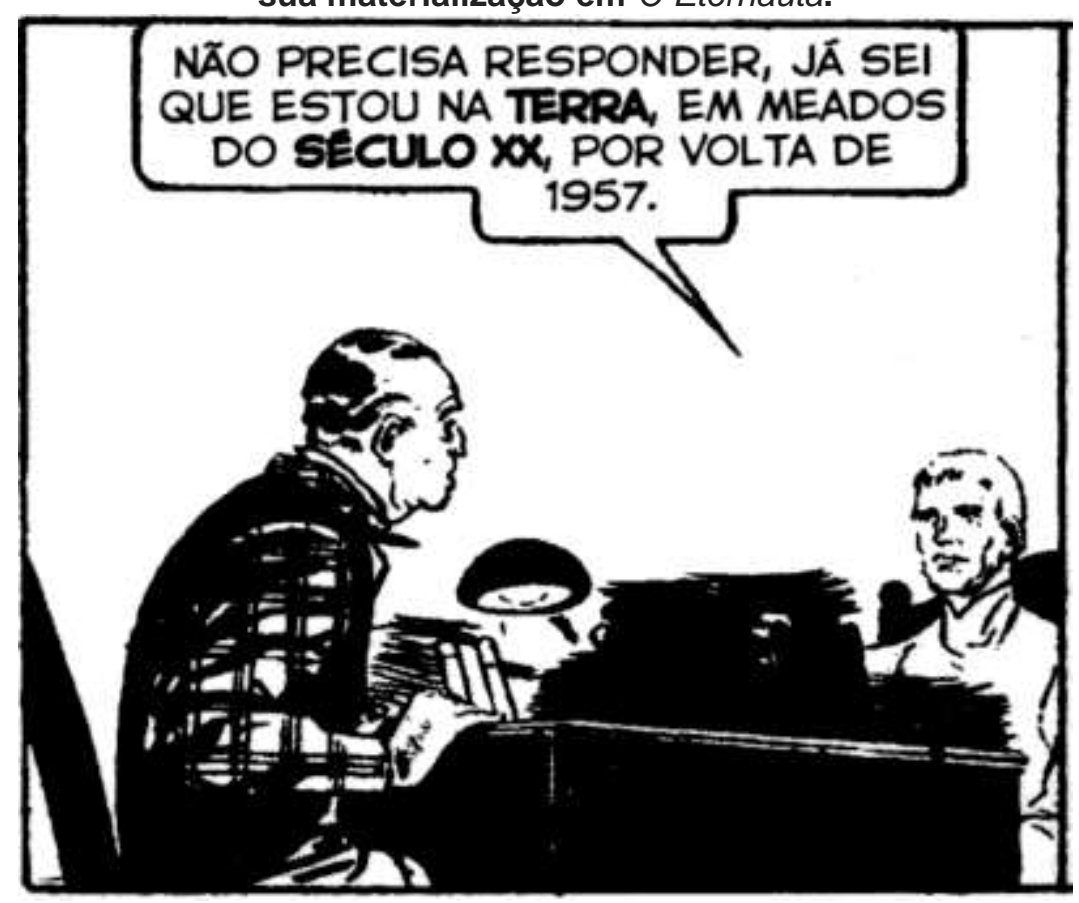

Fonte: acervo do autor. 
Fig. 60 - Germán Oesterheld apresenta-se na história O Eternauta II.

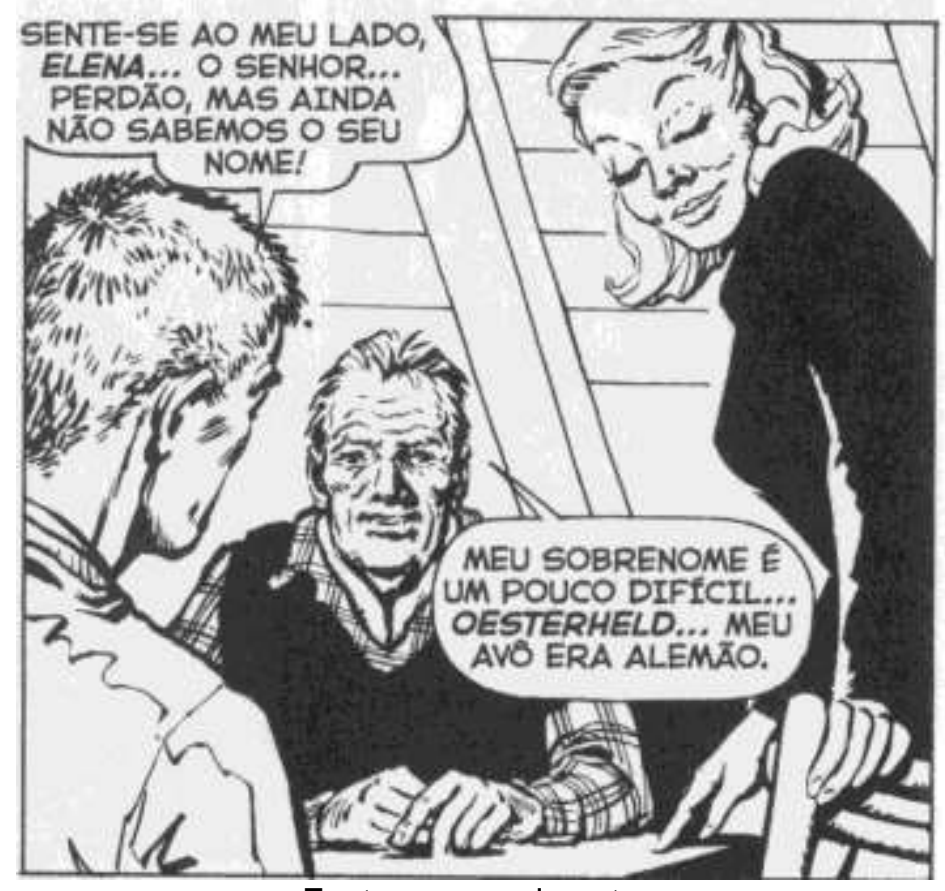

Fonte: acervo do autor.

Fig. 61 - Germán Oesterheld explicitamente numa tira de O Eternauta II.

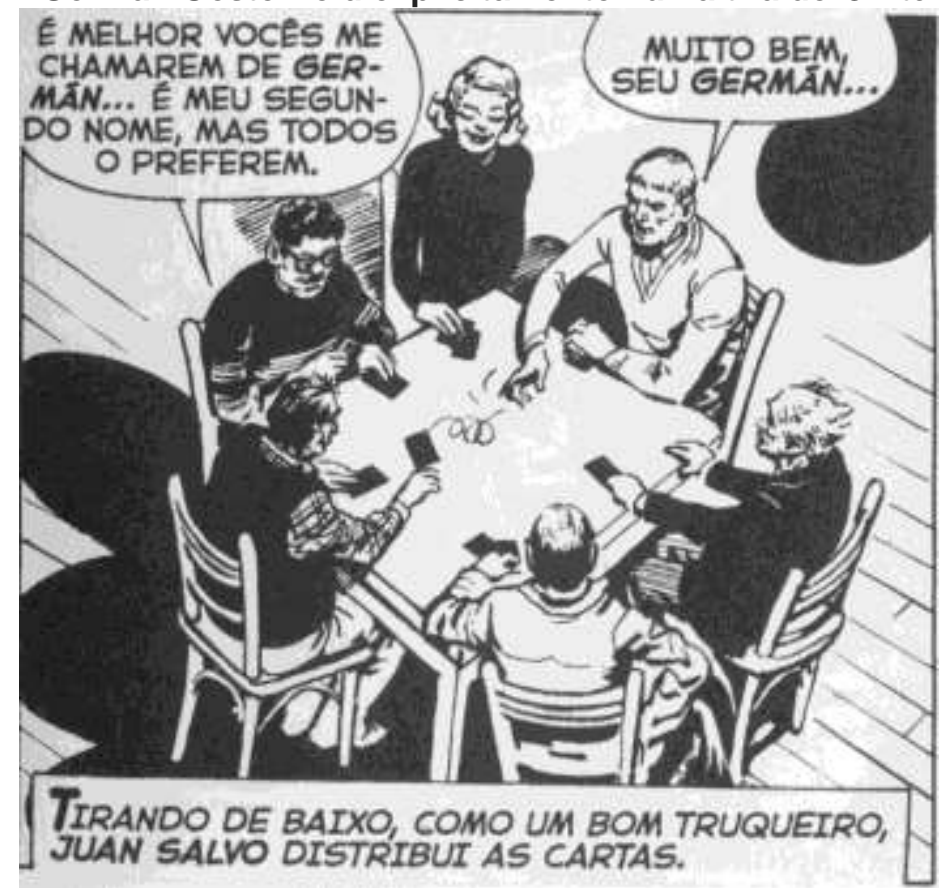

Fonte: acervo do autor. 
Fig. 62 - Germán Oesterheld e Juan Salvo desenvolvem uma ação conjunta em $O$ Eternauta II.

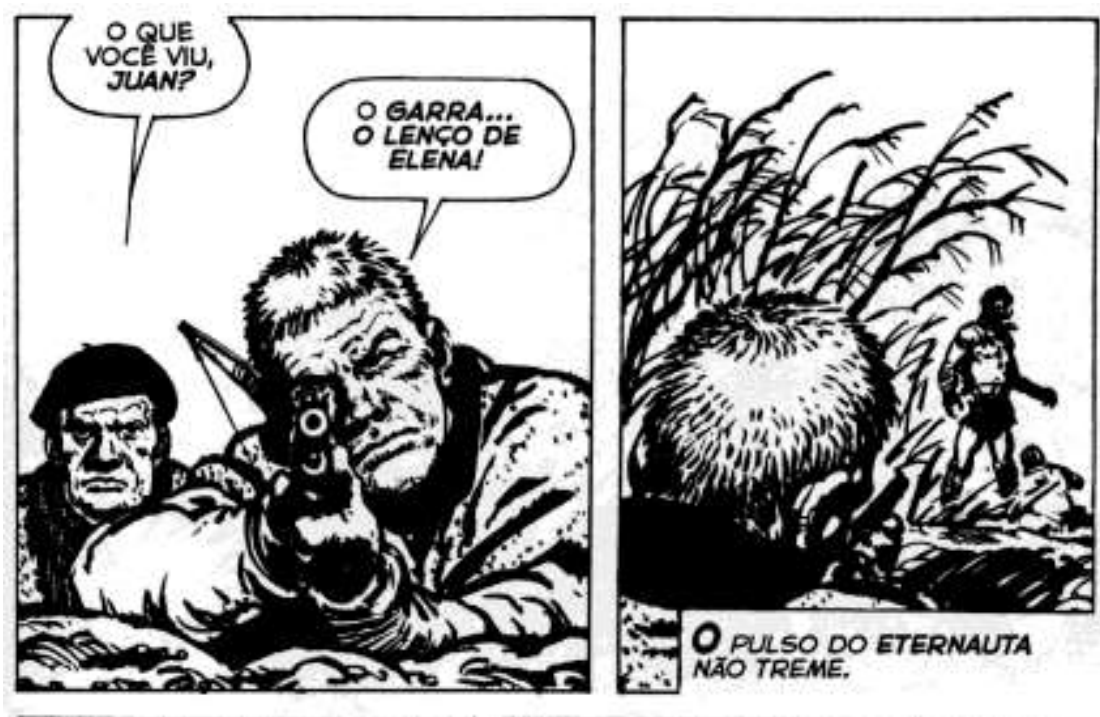

Fonte: acervo do autor.

Nesse cenário de ditadura militar e resistência armada de parte da sociedade civil, o roteirista Oesterheld usa o recurso da verossimilhança (em relação ao contexto e à profundidade psicológica dos personagens) para alternar ficção e realidade em sua obra O Eternauta II. Desse modo, pode-se afirmar que essa graphic novel tem o papel de apresentar ao leitor, de modo crítico e realista, os diversos problemas políticos típicos daquele momento histórico da América Latina, como a opressão do Estado sobre a sociedade civil, expressa, por vezes, por meio das ditaduras militares.

Lembra-se, também, que várias dessas situações expostas aos leitores de O Eternauta II, resultados de conflitos entre diferentes classes sociais que, por vezes, levaram a períodos ditatoriais e governos autoritários em diversas nações da América Latina, ainda não foram resolvidas em parte significativa desta região geográfica. Com isso, $O$ Eternauta II atua em favor para que exista, por parte do leitor, uma reflexão mais crítica e profunda acerca da realidade econômica, política e social desses povos.

São alguns exemplos dessas problemáticas a inadequada distribuição de renda, fazendo com que, por exemplo, em uma mesma cidade, existam bolsões de miséria e bairros nobres; o problema habitacional da falta de moradias e também de residências em locais sem um mínimo patamar de infraestrutura básica, o que inclui, por exemplo, atendimento educacional e de 
saúde adequado para seus moradores; o desemprego ou o trabalho exaustivo e insalubre para as parcelas de indivíduos pertencentes às classes que vivem do trabalho; salários insuficientes que mantêm a pobreza crônica de algumas das diversas camadas dessas populações de menor renda; transportes caros, insuficientes e de má qualidade; além da violência e opressão (econômica, social e política) a que esses grupos societários são submetidos cotidianamente.

A figura sessenta e três apresenta a situação de miséria extrema das classes que vivem do trabalho e, além disso, a repressão política a que são submetidas quando buscam se mobilizar, na sua luta cotidiana pela sobrevivência. Nela, tem-se o relato dessa pobreza, que atenta para o fato da distribuição desigual das condições materiais de sobrevivência da vida cotidiana para as camadas populares e da intensa repressão política a que as classes que vivem do trabalho são submetidas, pelos personagens "garras", que podem ser entendidos como os membros das forças do Estado responsáveis pela repressão política, ou mesmo dos indivíduos de grupos paramilitares de direita (por vezes, apoiados, de modo tácito - ou até mesmo explícito -, pelo Estado), o que guarda paralelos com o fato histórico do totalitarismo nazista.

Fig. 63 - Os membros das classes que vivem do trabalho relatando problemas econômicos e políticos na obra O Eternauta II.
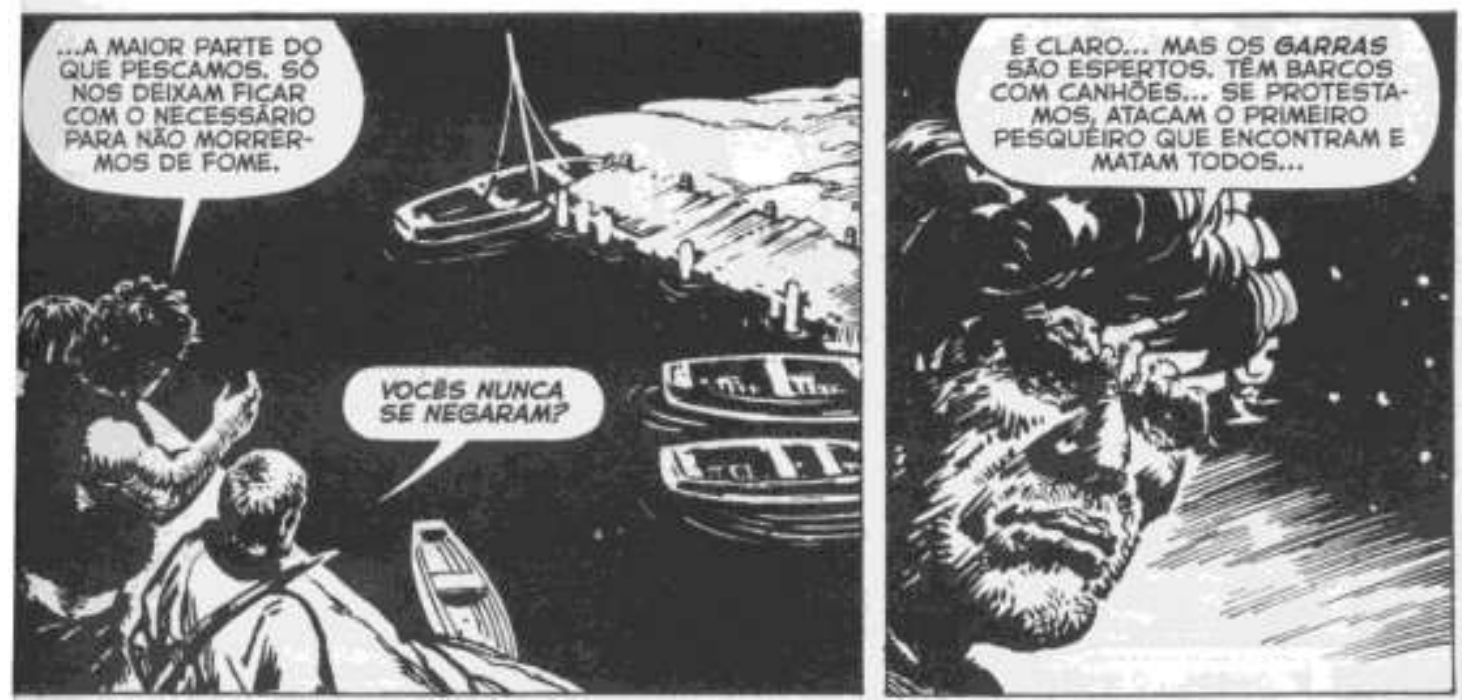

Fonte: acervo do autor. 
$\mathrm{Na}$ figura sessenta e quatro, os personagens "garras" são comparados com feras, num processo de desumanização dos indivíduos responsáveis pela repressão aos movimentos de resistência à ditadura militar argentina (e, por extensão, às ditaduras militares na América Latina).

Desse modo, é possível argumentar que Oesterheld retrata os repressores do Estado argentino como indivíduos em processo de perda das suas características humanas, em função do patamar de violência que esses agentes do Estado exerceram contra os membros da sociedade civil que estavam lutando pelo fim dessa ditadura militar e/ou que atuavam em favor de uma maior conscientização política dos membros da sociedade civil, trabalho esse realizado, na esmagadora maioria das vezes, de modo pacífico. Pode-se, inclusive, mencionar, em favor dessa interpretação, que a imagem do personagem "garra" apresentada na figura lembra, em grande medida, um ser animalesco, pois possui traços parecidos aos de um macaco.

Fig. 64 - A desumanização dos personagens "garras", responsáveis pela repressão política aos socialistas, em O Eternauta II.
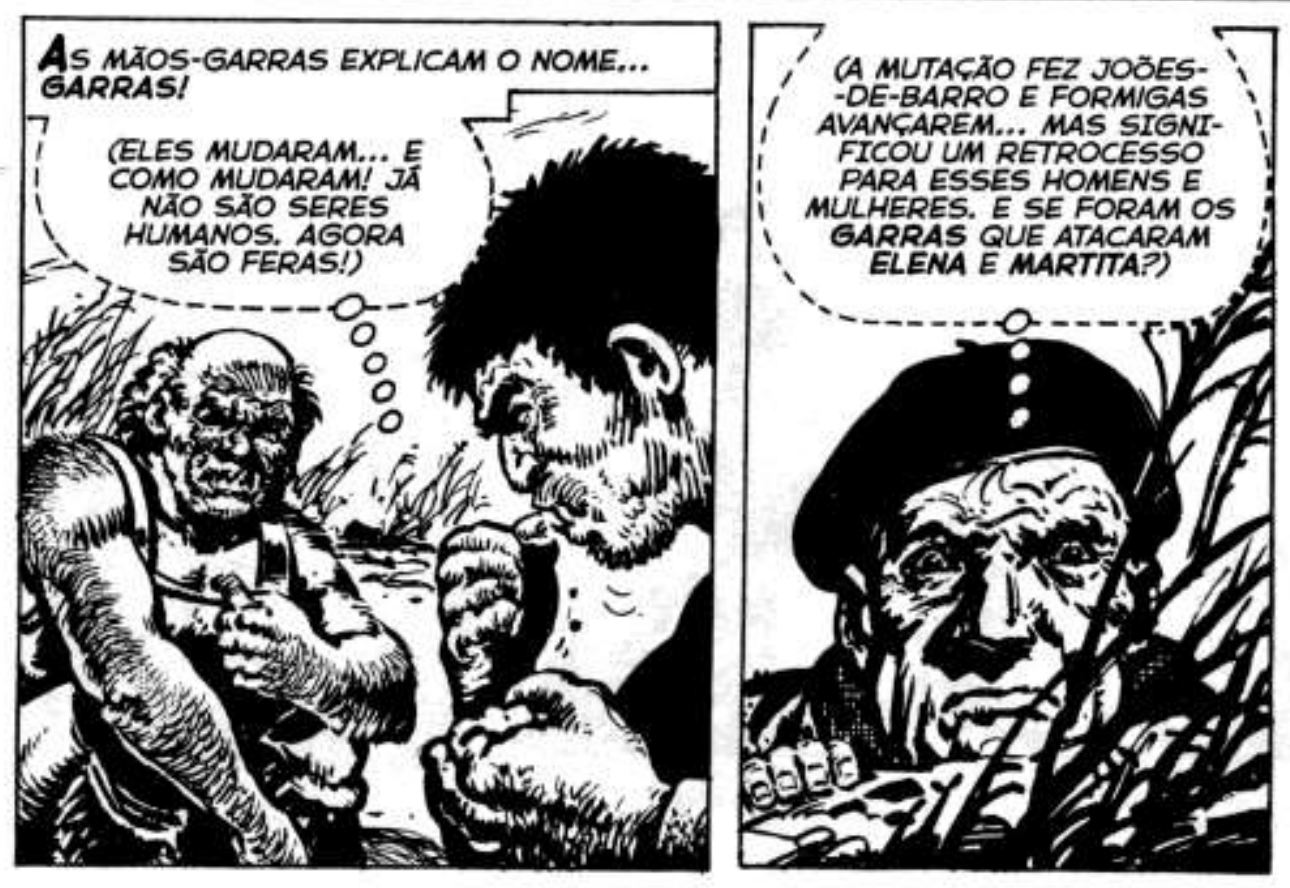

Fonte: acervo do autor. 
Parece ficar mais claro, então, que o objetivo do roteirista Oesterheld é o da conscientização social e política do seu público leitor e também de um chamado para um maior engajamento político em suas vidas cotidianas, pois O Eternauta II mostra a resistência das populações aos governos ditatoriais e incorpora o discurso dos membros da sociedade civil que lutam pelo fim das ditaduras militares, - e, num sentido mais amplo, pelo fim do capitalismo e consequente implantação do socialismo -, apresentando, nessa graphic novel, uma descrição explícita da luta de classes em um Estado capitalista.

Portanto, O Eternauta I/ é uma história em quadrinhos que possui uma mensagem política evidente, a da resistência às ditaduras militares, aos governos civis autoritários, e também ao capitalismo, que representa os interesses das classes burguesas (e demais estratos sociais que são partidários deste modo de produção) e chama as classes que vivem do trabalho para a luta por um novo mundo, de feições socialistas.

Tudo leva a crer que Oesterheld entendia que o protagonista verdadeiro de O Eternauta (e seu prolongamento O Eternauta II), é a coletividade em sua luta pela liberdade dos seres humanos, ou seja, o grupo humano, sendo este o único válido - embora seja adequado ressaltar que em O Eternauta II, Juan Salvo tem um protagonismo maior do que em relação a $O$ Eternauta, chegando a ter, em alguns momentos, poderes telepáticos.

Nesse sentido, é importante notar que a resistência realizada pela sociedade civil à invasão de seu território feita pelos extraterrestres nessas histórias em quadrinhos de Oesterheld é realizada por pessoas comuns, com a provável exceção, em alguns momentos, de Juan Salvo, em função de seus poderes telepáticos. Portanto, nessa história em quadrinhos, não existem super-heróis.

Desse modo, é adequado entender a produção quadrinística oesterheldiana como sendo uma das precursoras no deslocamento de uma produção voltada para o entretenimento em direção à trabalhos que visam, principalmente, a formação da consciência política e social do público leitor. 
Em um patamar inferior em termos de engajamento pela mudança social, quando comparado com o trabalho de Oesterheld, é possível afirmar que, posteriormente, outros quadrinistas seguirão o caminho de crítica ao capitalismo, como, por exemplo, o britânico Alan Moore e o sérvio radicado na França, Enki Bilal, que foram dois dos principais responsáveis por uma significativa mudança de status da produção quadrinística mundial, no último quarto do século $X X$, em função, por exemplo, de trabalhar com temas de complexo entendimento na sociedade contemporânea, como o fascismo, as obsessões pelo poder dos governantes e os protestos sociais. Ambos foram roteiristas de algumas das principais histórias em quadrinhos, ao longo da história deste meio de comunicação. Como exemplo, podem ser citados $V$ de Vingança, de Alan Moore e "A Feira dos Imortais", presente na Trilogia Nikopol, de Enki Bilal.

Em específico, nos quadrinhos $O$ Eternauta II, fica marcado o caráter político da história, com a exposição constante da luta entre diferentes estratos sociais, apresentando um cenário de conflitos e disputas por aspectos simbólicos, bens materiais, narrativas e primazia na visão de mundo. Evidencia-se, portanto, que a atuação política de Oesterheld se refletiu em sua produção, pois o roteirista expressa, por meio das suas histórias, as suas concepções, sentimentos e valores, buscando compartilhá-los com seus leitores.

E mais: Oesterheld utiliza os personagens de O Eternauta /l para expressar o seu pensamento político socialista e, de algum modo, antecipar uma discussão sobre a temática dos direitos humanos, numa época sombria de ditadura militar na Argentina e na grande maioria das nações latinoamericanas. Com isso, é possível dizer que existe uma importante dimensão ética e moral na trajetória intelectual e política de Oesterheld e, em consequência disso, nos personagens por ele criados.

Uma leitura possível da passagem de Oesterheld, como roteirista de $O$ Eternauta II, para Germán Oesterheld, como um dos principais personagens da obra $O$ Eternauta II (figuras sessenta e sessenta e um), é justamente a passagem do roteirista, um intelectual pertencente à classe média argentina, 
para um cidadão engajado na luta revolucionária. Essa é uma das diferenças mais significativas entre os quadrinhos $O$ Eternauta e O Eternauta II. Nos termos de Montero (2013):

\begin{abstract}
Em pouco tempo, Héctor teve a aventura diante de seus olhos. Mas desta vez não surgiu presa em um quadrinho. Agora a aventura se desenhava em um perfil mais humano; [...] era a luz de um farol que parecia iluminar um horizonte socialista, um futuro sem opressores ou oprimidos. Então, o Velho [Héctor Germán Oesterheld] não fez nada além de dar o salto em direção àquela aventura que já sentia pulsar dentro dele. (MONTERO, 2013, p. 127, tradução nossa) ${ }^{20}$.
\end{abstract}

Tal luta busca divulgar e implantar o socialismo, por meio da tomada do poder por uma organização político-militar (no caso argentino, os Montoneros), num processo eminentemente prático de luta pela liberdade dos membros da sociedade civil argentina (e latino-americana), em relação ao autoritarismo da ditadura militar e, num plano mais amplo, da opressão capitalista, entendida, por essa visão de esquerda, como uma sociedade hipócrita, onde as mercadorias são mais valorizadas do que os seres humanos. Desse modo, Oesterheld convida o leitor de quadrinhos para a reflexão e, também, para uma participação mais ativa na vida política, em busca de uma nova conformação social, fora das relações dominadas pelo capital.

É preciso ressaltar também o contexto histórico do momento dessa produção quadrinística. Tendo esse fato em vista, é provável que Oesterheld, em seus quadrinhos, buscasse trabalhar com o mecanismo de identificação entre o público leitor e os protagonistas de O Eternauta II.

A partir desses fatos, é sucetível o desenvolvimento de estudos acerca das interações sociais entre os diversos personagens dessa história em quadrinhos, e, através de um processo de recontextualização, uma possível formação de um pensamento crítico acerca das relações sociais do mundo

\footnotetext{
${ }^{20}$ En poco tiempo, Héctor tuvo la aventura ante sus ojos. Pero esta vez no emergia encerrada en una viñeta. Ahora la aventura se dibujaba en un perfil más humano; [...] era la luz de un faro que parecia alumbrar un horizonte socialista, un futuro sin opresores ni oprimidos. Entonces, el Viejo [Héctor Germán Oesterheld] no hizo otra cosa que dar el salto hacia esa aventura que ya sentía palpitar en su interior.
} 
contemporâneo, dando margem a uma maior problematização acerca dessas temáticas. Em suma: Oesterheld aparenta convidar o seu público leitor para a ação política e para a batalha entre as classes sociais que ocorre na vida real. Inclusive, a forma de organização dos personagens da obra O Eternauta II, frente à invasão extraterrestre, guarda intensa correspondência com o modo de organização político-militar dos Montoneros, em sua luta pelo fim da ditadura militar argentina e pela transformação da sociedade capitalista para uma que iria em direção ao socialismo, numa formação muito próxima de um exército popular armado, que era comandado por membros da sociedade civil.

Para ilustrar tal fato, pode-se notar, nas figuras sessenta e cinco e sessenta e seis, que Oesterheld e Solano López apresentam ao leitor "colunas guerrilheiras", com alguns indivíduos portando fuzis. Essas formações organizadas de modo militar guardam paralelos com grupos armados de resistência civil às ditaduras e foram utilizadas, por exemplo, pelos Montoneros argentinos e também pelos Tupamaros uruguaios.

$\mathrm{Na}$ figura sessenta e cinco, ao se referir ao narrador à "(...) a nobreza dos que vivem uma luta direta com a natureza. A verdadeira nobreza. A que ignora ser nobre", pode-se afirmar que ele está se referindo à luta das camadas populares sendo executada em terreno hostil, por uma causa nobre, como a tomada do poder em favor das classes que vivem do trabalho, sendo realizada por atores sociais humildes que não buscam a glória nem a vaidade, mas sim uma sociedade mais justa, com igualdade de oportunidades para todos, sem opressões (culturais, econômicas, políticas e sociais, por exemplo) de uma classe social sobre outra. 
Fig. 65 - Exemplo de uma "coluna guerrilheira" presente na história em quadrinhos $O$ Eternauta II.

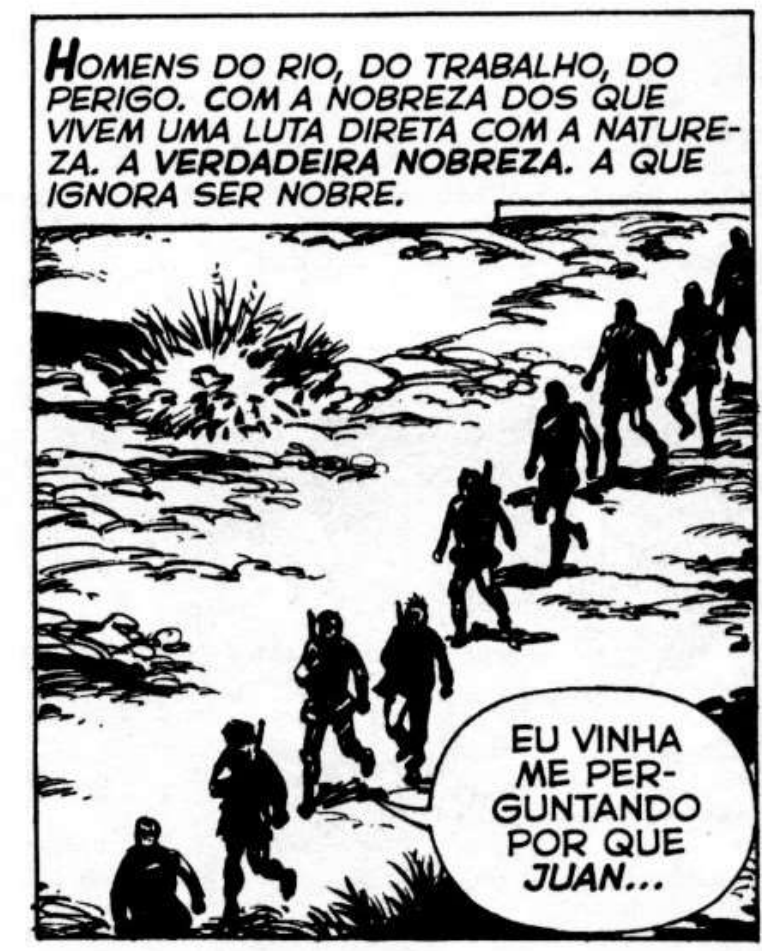

Fonte: acervo do autor.

Já na figura sessenta e seis, pode-se entender as palavras do balão como uma indicação de que os indivíduos dessa célula de resistência - ou dessa coluna guerrilheira -, estão cientes de que podem não voltar para as suas residências. Assim, uma leitura possível desse cenário é a de que, nesse momento, as vidas desses seres humanos pertencem à organização políticomilitar na qual atuam. Também não é possível saber quantas pessoas irão morrer até que esse conflito político e social termine. Se é que vai ter um fim. Nesse sentido, é importante lembrar das palavras de Monteiro (2013), quando se refere ao tema da opressão na obra quadrinística de Oesterheld: "Aí está sua história como aprendizagem para os homens [...]. É melhor não perder as lições de sua derrota". (MONTERO, 2013, p. 73, tradução nossa) ${ }^{21}$.

\footnotetext{
${ }^{21}$ Ahí está su historia como aprendizaje para los hombres [...]. Más vale no dejar passar las
} lecciones de su derrota. 
Fig. 66 - Exemplo de uma "coluna guerrilheira" presente em O Eternauta II.

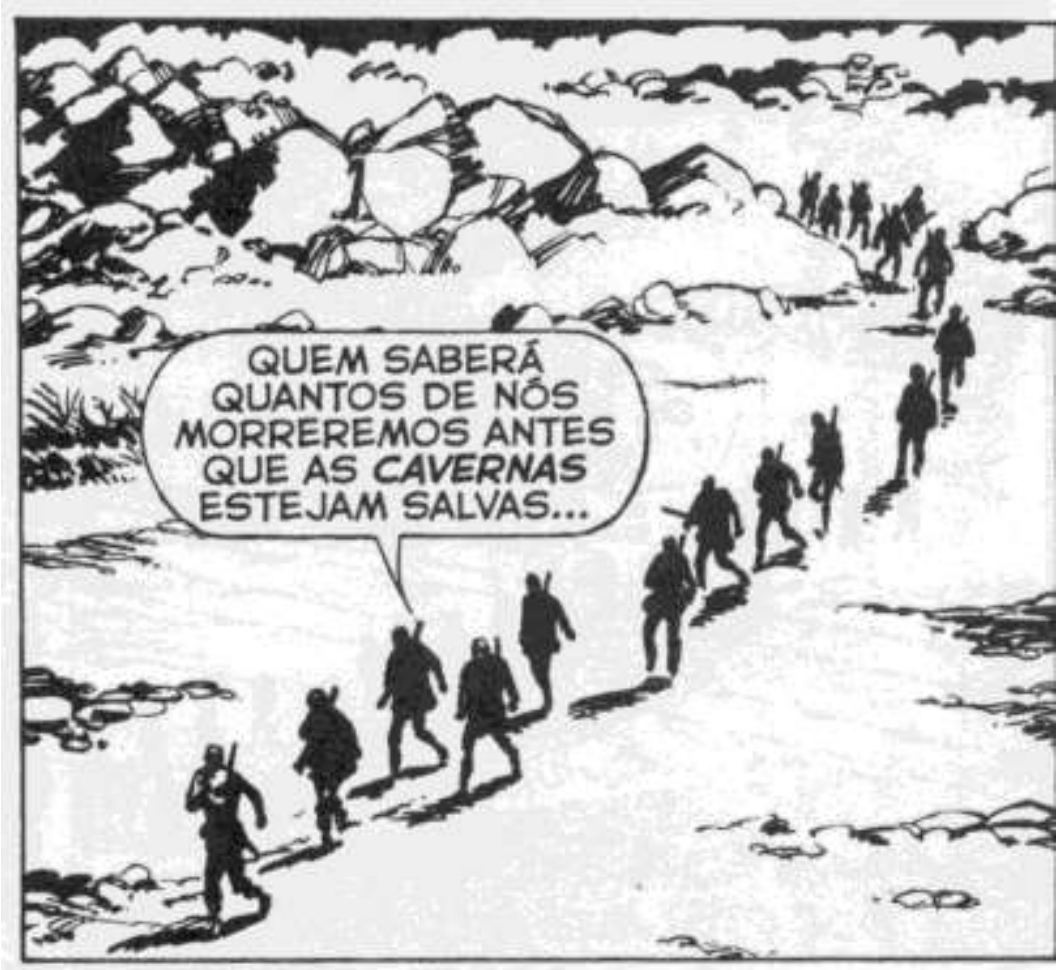

Fonte: acervo do autor.

Desse modo, O Eternauta Il apresenta ao leitor uma mobilização política contínua dos atores sociais ao longo da narrativa, os quais fazem uso de diferentes estratégias políticas e também de uma organização que tem como meta a conquista do poder, buscando uma nova conformação social. Para tanto, realizam um processo de conscientização política do público leitor, enforcando a necessidade da luta pelo poder para a resolução dos conflitos políticos e sociais existentes nas sociedades latino-americanas, nesse momento histórico.

Na figura sessenta e sete, é apresentada ao leitor a importância da luta coletiva por um objetivo maior, como, por exemplo, como dito anteriormente, a tomada do poder. Por vezes, tal fato tem uma importância maior até mesmo do que a vida de algum(ns) militante(s), em nome da manutenção desta luta política. Em outros termos, pode-se afirmar que: "Por trás de todo o militarismo estava à disposição de um chefe montonero para sacrificar dezenas de vidas, 
entre elas as de vários companheiros proeminentes, em uma contra-ofensiva [...].”. (GILLESPIE, 1998, p. 316, tradução nossa) ${ }^{22}$.

Fig. 67 - 0 personagem Juan Salvo (O Eternauta) e seu discurso em favor da luta por uma causa maior, mesmo que tal fato custe algumas vidas, em O Eternauta II.

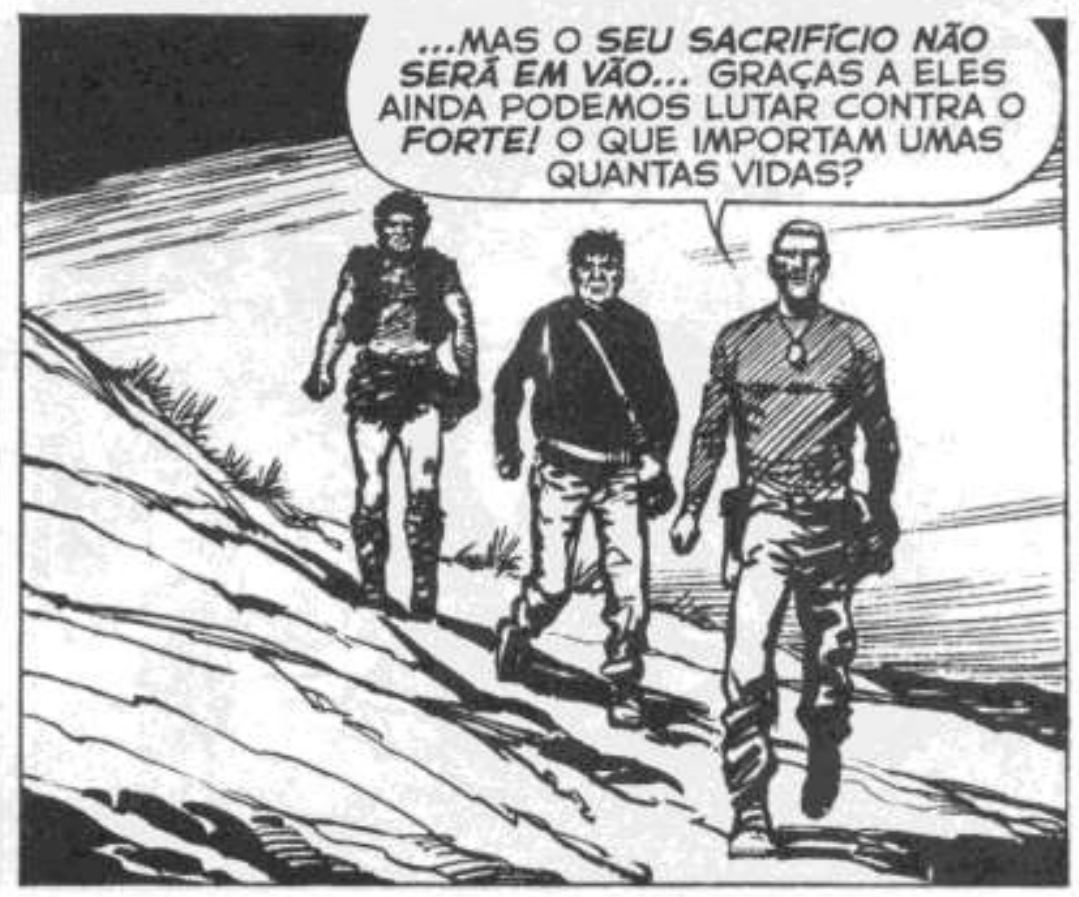

Fonte: acervo do autor.

Com isso, é possível afirmar que o personagem Juan Salvo, o Eternauta, possui um discurso próximo do peronismo de esquerda da organização político-militar dos Montoneros, que coloca, num primeiro plano, os objetivos desse movimento político-militar, ou seja, a resistência civil à opressão do Estado argentino dirigido pelos militares (que nesse momento histórico possuíam relações amistosas com os estratos sociais dominantes).

Para tanto, por vezes, talvez seja até necessário que alguns militantes percam suas vidas, o que configura um contexto de guerra. Para confirmar essa injunção, basta ler o final da fala de Juan Salvo, no mesmo balão da figura sessenta e sete: "O que importam umas quantas vidas?". Ou seja, pode-se

${ }^{22}$ Detrás de todo el militarismo estava la disposición de um jefe montonero a sacrificar docenas de vidas, entre ellas las de vários compañeros prominentes, en una contraofensiva [...]. 
dizer que Oesterheld analisava os padrões de comportamento social e usou os quadrinhos como ferramenta política para um maior aprofundamento acerca da reflexão sobre o mundo contemporâneo e também para promover uma maior conscientização e mobilização política da sociedade civil, em busca de uma transformação cultural, política e social do mundo moderno, devendo essa ser realizada de modo coletivo.

A trajetória de Oesterheld não só como intelectual, mas também como militante ativo da esquerda é, como já mencionado anteriormente nesta tese, anterior à confecção de O Eternauta II, pois já no final da década de 1960 tal fato fica evidenciado com a publicação na Argentina da biografia de Ernesto "Che" Guevara, em formato de histórias em quadrinhos, em parceria com Alberto Breccia e Enrique Breccia. Ressalta-se, no entanto, que não existe um consenso e uma data exata conhecida do ingresso de Oesterheld no grupo político-militar dos Montoneros. O ano conhecido é o de 1973, com o seu trabalho como roteirista de histórias em quadrinhos na publicação El Descamisado, que estava ligada a este grupo.

Diante do fato de que Oesterheld, sem exagero algum, foi um autor que defendia suas ideias e sua visão de mundo até a morte, tendo em vista a sua firmeza de concepção acerca da realidade social, esse roteirista terminou sendo um dos cerca de 30.000 desaparecidos políticos durante o período em que o general Videla governou a Argentina, ou seja, entre 1976 e 1981.

De acordo com Fossati (1997), Oesterheld está desaparecido desde abril de 1977. Von Sprecher (2010), menciona a data de desaparecimento em 24 de abril de 1977. Reati (2009) menciona que Oesterheld chegou a ser visto, com vida, em 1978. A Organização das Nações Unidas considera Oesterheld detido e desaparecido desde 1977. Esse momento histórico pertence, como mencionado no parágrafo acima, ao período da ditadura militar do general Videla.

E, como consta no livro Oesterheld en tercera persona (2008), Oesterheld, na condição de preso político da ditadura militar, foi levado para diferentes locais (centros clandestinos) onde ficavam os presos políticos, tendo sido torturado e, mesmo assim, não dando maiores informações sobre seus colegas 
militantes de esquerda. Nesses locais de tortura também passaram várias outras importantes personalidades da história argentina, como o sociólogo e ensaísta Roberto Carri, assassinado em 1977, e do cineasta Pablo Szir, assassinado em 1977 ou 1978 (ambos também integrantes do grupo Montoneros), como é mencionado na página web sobre Héctor Oesterheld do portal Elortiba ${ }^{23}$.

Além de Oesterheld, suas quatro filhas: Estela Inés, Diana Irene, Beatriz Marta e Marina, desaparecidas aos vinte e quatro anos, vinte e três anos, dezenove anos e dezoito anos respectivamente, além dos maridos de Diana (Raul Carlos Araldi) e de Marina (Oscar Alberto Seindlis), também fazem parte da lista dos desaparecidos políticos. Segundo Montero (2013), primeiro desapareceu Beatriz Marta (em junho de 1976); posteriormente Diana Irene (em julho de 1976); em um terceiro momento foi Marina (em novembro de 1977) e, por último, Estela Inés (em dezembro de 1977). Ainda segundo Montero (2013), existe uma versão de que a filha mais velha de Osterheld possa ter cometido o suicídio antes de ser morta (ao ingerir um comprimido de cianureto).

Já Gabriel Solano López, filho de Francisco Solano López, desenhista dessa história em quadrinhos, foi detido durante a ditadura militar argentina, também por suas ligações políticas com os Montoneros. Posteriormente, exilou-se, com seu pai, na Espanha. Em função disso, a elaboração final dos quadrinhos de O Eternauta // foi realizada em território espanhol, com base nos roteiros de Oesterheld, pelo desenhista Solano López, como consta na introdução da versão argentina desta obra, El Eternauta II, denominada "De Frente a la Esfinge", escrita por García (2012).

Oesterheld era (e, ainda é) uma das pessoas mais reconhecidas pelo seu trabalho no meio artístico e cultural argentino, latino-americano e europeu. A figura sessenta e oito apresenta uma representação acerca da mobilização da sociedade civil em busca do paradeiro de Oesterheld feita, pela primeira vez,

\footnotetext{
${ }^{23}$ Disponível em: <http://www.elortiba.org/etern1.html>. Acesso em: 13 jul. 2016.
} 
na revista argentina Feriado Nacional, no início da década de 1980, por Felix Saborido.

Desse modo, fica claro mais uma vez que Oesterheld era, naquele momento, um profissional conhecido internacionalmente pelo seu trabalho inovador com as histórias em quadrinhos, tendo trabalhado com mais de cem desenhistas, de diferentes nacionalidades e, ao longo de sua vida, criado mais de cem personagens principais.

Mais recentemente, a sua produção quadrinística e o seu envolvimento das discussões dos temas culturais e políticos latino-americanos foram lembrados por um conjunto de obras e eventos que buscaram aprofundar 0 estudo acerca de seu pensamento. A publicação de biografias que tentam reconstruir o seu percurso como intelectual e roteirista de histórias em quadrinhos, bem como o número significativo de artigos que discutem o seu trabalho com quadrinhos e as diversas exposições já realizadas sobre a sua obra são uma prova disso.

Inclusive, deve-se salientar que o evento mais recente visando a divulgação da obra de Oesterheld, ao que se saiba, ocorre ainda no Brasil, na cidade de São Paulo: a exposição "As várias faces de Héctor Germán Oesterheld - Mostra do acervo da Gibiteca Henfil" do Centro Cultural São Paulo, organizada pelo argentino Miguel Angel Foncueva em parceria com Douglas Pigozzi e Hugo Abud, que teve início em 22 de agosto de 2018 (com previsão de término em 5 de março de 2019) ${ }^{24}$. Foncueva, aliás, participou, nos últimos anos, da organização de cerca de vinte exposições sobre a obra de Oesterheld.

24 Disponível em: <http://centrocultural.sp.gov.br/site/eventos/evento/as-varias-faces-de-hectorgerman-oesterheld-mostra-do-acervo-da-gibiteca-henfil/>. Acesso em: 26. nov. 2018. 
Fig. 68 - Poster de Felix Saborido acerca do desaparecimento de Oesterheld, publicado originalmente na Revista Feriado Nacional, Buenos Aires, no 5, out. 1983.

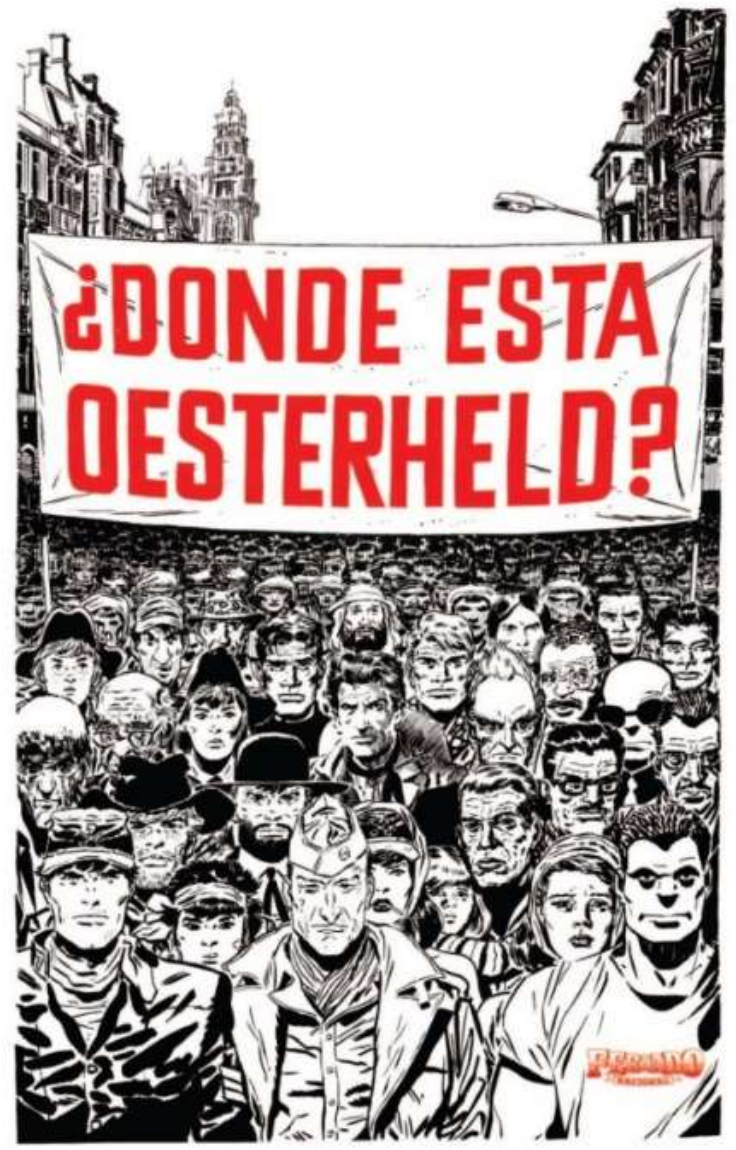

Fonte: Globedia. El diário colaborativo. Disponível em: <http://globedia.com/macrismodesaparecer-eternauta-hipocresia-aparente-politica>. Acesso em: 26 nov. 2018. 


\section{CONSIDERAÇÕES FINAIS}

Existem restrições, ou até mesmo incompatibilidades, entre a liberdade de criação cultural e as formas autoritárias de governos, civis e militares, ao longo da História da humanidade. Tal fato ocorre em função de vários fatores como, por exemplo, o da repressão política que é exercida sobre autores críticos e reflexivos, afetando, com isso, as suas possibilidades de produção nos mais diferentes âmbitos do conhecimento.

Em função do seu trabalho com as possibilidades e os limites da liberdade de expressão, o roteirista de histórias em quadrinhos, Héctor Germán Oesterheld, um dos principais intelectuais da História da América Latina, foi cerceado em seu trabalho quadrinístico (e em sua vida).

Em linhas gerais, os quadrinhos de Oesterheld oferecem ao leitor uma complexidade de reflexão acerca das mais variadas problemáticas dos povos latino-americanos, tratando de temas culturais, econômicos, filosóficos, políticos e sociais, além dos seus processos estruturais e históricos, buscando a origem, ou seja, a "fonte" desses fatos e, a partir disso, realizam um trabalho que envolve tanto questionamentos morais como também acerca dos valores humanos.

Ou seja: a produção quadrinística oesterheldiana faz um uso original do potencial comunicativo dos quadrinhos ao analisar o papel que as instituições sociais do mundo contemporâneo exercem sobre os indivíduos nos diversos processos de socialização e, além disso, as formas e as interações no modo como é feito o controle social dos estratos sociais dominados. Oesterheld, por meio das suas histórias em quadrinhos, busca desconstruir os padrões societários estabelecidos pelos detentores do poder.

Nesse sentido, uma leitura possível da sua produção quadrinística, principalmente em relação aos roteiros de seus quadrinhos feitos a partir de Che (com desenhos de Alberto Breccia e Enrique Breccia) e El Eternauta (com desenhos de Alberto Breccia), é a de que o mundo capitalista, com a sua imposição de um pensamento único, é um escândalo sem fim, uma galeria de horrores, pior que o pior pesadelo imaginável, em função da opressão sofrida 
por alguns grupos societários, os não-proprietários, ou seja, a maioria dos seres humanos, que pertencem às classes que vivem do trabalho (e não do capital). Tal contexto expõe ao público leitor de quadrinhos a existência de um quadro social de exploração e, consequentemente, de desigualdades materiais, o que envolve tanto problemáticas econômicas, como políticas e sociais. Ou seja, de acordo com essa linha de raciocínio, o capitalismo, para a imensa maioria da população, é, na verdade, uma prisão material e psicológica, que é perpetuada, num primeiro momento, por meio da internalização de regras e valores impostos pelos estratos sociais dominantes, e, num segundo momento, caso necessário, pela repressão política e social.

Desse modo, as histórias em quadrinhos de Oesterheld têm o mérito (e a coragem) de reinterpretar uma visão de mundo predominante acerca da América Latina, ao fornecer ao leitor uma outra forma de representação da realidade, além de possuir um papel significativo no deslocamento da produção quadrinística argentina (e latino-americana) do entretenimento para a conscientização social do seu público leitor, ao refletir criticamente sobre essa realidade econômica e social, que se apresenta no interior dessa organização da vida política latino-americana, favorecendo um entendimento mais amplo acerca da complexidade deste modo de produção.

Tal produção quadrinística convida ao leitor, por vezes, para que saia da inércia da vida cotidiana em direção a uma mobilização política e social, num cenário político fortemente influenciado pela Revolução Cubana, em 1959, e, posteriormente, pela mobilização política que culminou com a eleição e governo de Salvador Allende Gossens, no Chile, em 1970, fatos esses que tiveram repercussão em parte significativa da América Latina, tornando, desse modo, mais complexo o contexto mundial da Guerra Fria e da luta entre diferentes classes sociais no interior dessas sociedades latino-americanas.

Portanto, as histórias em quadrinhos de Oesterheld trazem para o meio quadrinístico latino-americano um maior sentido de maturidade e também de responsabilidade individual e social, num exercício intenso de cidadania, pois possuem, em seu conteúdo, reflexões e discussões de significativa profundidade acerca dos mais variados temas, como as políticas econômicas, as organizações sociais e os princípios éticos da ação política, tratando, desse 
modo, das relações sociais e também de suas estruturas fundamentais, no contexto da sociedade contemporânea. Desse modo, Oesterheld, por meio dos quadrinhos, trata das temáticas do autoritarismo, da eliminação do outro, da luta política cotidiana, dos mecanismos de silenciamento e da repressão política.

Em específico, El Eternauta e El Eternauta II (ambos com desenhos de Francisco Solano López), objetos de estudo desta tese, são dois documentos que pertencem ao patrimônio cultural latino-americano, sendo histórias em quadrinhos dos gêneros da aventura e da fiç̧ão-científica, que fornecem ao leitor, em vários sentidos, uma contribuição singular para um entendimento mais amplo acerca das problemáticas pertencentes à realidade latinoamericana, como as que envolvem o estudo das estruturas sociais, ou seja, os diversos padrões de organização social, como as normas, os papéis sociais e os valores de um grupo societário.

Desse modo, pertencem ao que pode ser nomeado como "quadrinhos produzidos em ambientes sociais totalitários", ou seja, narrativas realizadas em cenários em que existe uma dominação permanente da maioria dos seres humanos por um grupo de pessoas, existindo, consequentemente, uma obediência praticamente absoluta dos submetidos, que acabam tendo seu estilo de vida moldado de acordo com interesses alheios a si próprios. Tal fato retrata, portanto, uma sociedade fascista (e violenta), evidenciando o perfil autoritário dos invasores alienígenas, ou, dito em outros termos, dos membros do Poder Público.

E, além disso, El Eternauta e El Eternauta II são contribuições quadrinísticas que apontam a necessidade e a possibilidade (prática) da construção de uma nova sociedade, fundada em outros valores morais, em um modo de viver envolvido por um novo conjunto de hábitos, por meio de uma compreensão mais ampla dos temas coletivos, buscando novas formas de experiências sociais, próximas do socialismo.

Oesterheld evolui, ao longo dessas histórias em quadrinhos, de um roteirista pertencente à classe média argentina a um militante de um agrupamento político-militar (sem deixar seu trabalho de roteirista de histórias em quadrinhos, e, por vezes, inclusive, utilizando-o de modo combativo). 
Oesterheld, em El Eternauta II, chega a participar ativamente da história, na forma de um dos seus principais personagens, o que guarda intensos paralelos com a edificação de um teatro de sombras, ao fazer uso de projeções para explicitar uma realidade social.

Com isso, Oesterheld chega a usar as histórias em quadrinhos como um meio de difusão de ideias nos âmbitos culturais e sociais, trabalhando com a capacidade de leitura dos textos e das imagens do leitor e, além disso, contribuindo com a formação política desse público, tanto na sua consciência, como também em sua organização política, ao tratar de temas da maior relevância para aquela época e também para os dias atuais, como os direitos humanos e o pacifismo, contribuindo com a formação de um novo olhar acerca das problemáticas políticas e sociais, favorecendo um processo de reflexão mais amplo do público leitor.

Ou seja, é possível afirmar que Oesterheld toma a forma de um "roteirista da revolução", com um intenso comprometimento político e adesão ao peronismo revolucionário, fruto de sua observação acerca dos fenômenos sociais e do questionamento acerca de várias das relações econômicas (meios de produção) e políticas (poder) e suas problemáticas na América Latina, em reação a uma ordem social injusta, numa aproximação com o socialismo. Portanto, ocorre uma condenação moral do capitalismo, que expressaria somente o interesse material e simbólico de uma parcela minoritária da sociedade como um todo.

Desse modo, é possível também defender que Oesterheld buscava transformar um cenário de caos monstruoso em um sonho fantástico, no qual existiria (ou existirá) uma realidade social em que todos os seres humanos tenham plenas condições de desenvolvimento artístico, cultural, esportivo e intelectual, no interior de um cenário social em que não exista mais a prática da opressão. Para tanto, seu instrumento pedagógico de trabalho foram as histórias em quadrinhos.

Oesterheld aproxima-se do pensamento social de Marx [1888] (2005), em suas Teses sobre Feuerbach, (escrito originalmente em 1845, redigido e publicado, pela primeira vez, em 1888, por Friedrich Engels) e, de modo mais específico, em relação à tese de número onze, onde menciona que "os filósofos 
não fizeram mais que interpretar o mundo de forma diferente; trata-se porém de modificá-lo" (MARX, 2005, p. 8).

Tal fato faz com que o ser humano ganhe autonomia, deixando de ser apenas um interprete do mundo contemporâneo, para auxiliar na formação de uma nova organização social, desse modo, construindo sua própria história sendo, contudo, limitado por condições históricas específicas, ou seja, as possibilidades de intervenções políticas e sociais podem se apresentar (ou não) aos indivíduos e as coletividades. Lembrando, novamente, o filósofo e sociólogo citado no parágrafo anterior, agora em sua obra O 18 Brumário:

Os homens fazem sua própria história; mas não a fazem como querem; não a fazem sob circunstâncias de sua escolha e sim sob aquelas com que se defrontam diretamente, legadas e transmitidas pelo passado. (MARX, 1969, p. 17).

Ou, em outros termos: El Eternauta e El Eternauta II são, em grande medida, representações figuradas da realidade, ou seja, alegorias políticas representativas de uma luta social, que passa, cada vez mais, ao longo do percurso dessas duas histórias em quadrinhos, a ter contornos de resistência ao capitalismo, tendo no horizonte a constituição de um novo mundo social, resultante de possíveis transformações das relações sociais do mundo contemporâneo.

Uma leitura possível é que tal fato fica exposto ao leitor de modo diverso nas duas versões: em El Eternauta, por meio de um profundo altruísmo, de uma linha de pensamento com valores humanistas, do pacifismo e da tolerância política expressos por meio da narrativa de Oesterheld, na sua denúncia das consequências de uma possível guerra atômica (década de 1950, contexto da Guerra Fria) e seus alertas acerca dos perigos da radioatividade; e em El Eternauta II, por meio de uma luta política entre classes sociais, com as classes que vivem do trabalho possuindo um ideário próximo de um peronismo de esquerda apoiado por setores populares, ou mesmo do socialismo marxista, o que remete a um plausível desafio coletivo da formação social de um "novo mundo", fundado em uma nova sociabilidade que valoriza, 
sobretudo, o ser humano (década de 1970, período de ditaduras militares na América Latina).

Com isso, Oesterheld apresenta ao leitor duas leituras políticas que estão ajustadas ao cenário social de dois momentos históricos diferentes da Argentina (e da América Latina). Tal cenário social faz com que os quadrinhos El Eternauta II possuam um roteiro mais combativo do ponto de vista político do que a versão anterior, expressando, por vezes, uma miséria socialmente reproduzida e perpetuada para alguns estratos sociais.

Outro fato que é necessário mencionar é a trajetória do protagonista da história, Juan Salvo (O Eternauta), durante o período compreendido entre as produções de El Eternauta e El Eternauta II, ocorrendo um processo de politização, no qual o personagem Eternauta passa a procurar alternativas mais concretas para lutar em favor de novas formas de interação e organização societária, de contornos mais humanistas, tendo como fundamento um ideal de justiça e liberdade, numa aproximação com o socialismo. Ou seja, buscava uma modificação profunda (e intensa) na lógica atual do sistema de produção (que influencia as demais relações no interior de uma sociedade) e, consequentemente, do comportamento dos atores sociais.

Isso posto, tanto El Eternauta como El Eternauta II, de Héctor Germán Oesterheld e Francisco Solano López, trabalham fortemente com a formação da identidade política e social do público leitor, ao expor (por vezes, de modo alegórico) pensamentos e reflexões mais densos e profundos, num esforço de desenvolver nos membros da sociedade civil a consciência da possibilidade de vitória em uma luta política entre diferentes classes sociais, em uma busca por novas configurações sociais. Em suma: Oesterheld reconhece, explica, e, além disso, busca influenciar na formação da realidade social.

Portanto, essas duas histórias em quadrinhos tematizam acerca das interações entre os atores sociais e as coletividades e, desse modo, sobre a construção da identidade social, o que trata tanto do estilo de vida dos indivíduos em um grupo societário (o que está ligado ao modo como as pessoas se percebem no mundo) e como podem atuar na sociedade contemporânea, numa crítica aos valores do mundo capitalista. 
Esse fato torna essas duas histórias em quadrinhos de incalculável valor simbólico para o patrimônio cultural dos povos latino-americanos e, em especial, das classes que vivem do trabalho, como um elemento que auxilia na formação das identidades individuais e coletivas. Com isso, Oesterheld e Solano López valorizam os quadrinhos, como um meio de comunicação autônomo, ao fazer uso, em uma mesma história, de elementos verbais e visuais (além dos vários outros recursos de linguagem passíveis de estarem presentes nas histórias em quadrinhos).

Essa utilização do campo simbólico, como meio de conscientização da sociedade civil, num trabalho com a mentalidade das massas por meio das imagens, das palavras e das figuras de linguagem, em conjunto, atua no interior do campo da Comunicação de modo combativo, distanciando-o do entretenimento, numa aproximação das histórias em quadrinhos com um público leitor de perfil mais adulto, ao tratar de temáticas que retomam discussões acerca da cidadania, dos direitos individuais e coletivos, incluindo um debate sobre os direitos humanos.

E Oesterheld, em específico, ao dotar os seus personagens de reações mais próximas de um ser humano real, distancia-os dos super-heróis tradicionais do mainstream do mercado de histórias em quadrinhos (como o Batman, o Homem-Aranha e o Super-Homem, em linhas gerais). Desse modo, Oesterheld evita simplismos maniqueístas como o bem versus o mal, ao tornar mais complexa a relação entre os personagens de suas histórias em quadrinhos. E essa é uma de suas principais inovações para o meio quadrinístico, tornando ainda mais original o seu trabalho como roteirista do meio, tendo em vista o cenário de produção dessa mídia, naquele momento histórico.

Em função do exposto acima, o trabalho quadrinístico desenvolvido em El Eternauta e El Eternauta I/ tem o papel de consolidar e reforçar a linguagem dos quadrinhos como meio de comunicação de massa, ao mesmo tempo em que trabalhava com a reflexão crítica dos leitores, com o questionamento acerca das problemáticas políticas e sociais latino-americanas, ampliando, desse modo, a discussão e o entendimento acerca do mundo contemporâneo. 
E, além disso, propor ao leitor formas práticas de luta por uma sociedade mais igualitária e justa, por meio da mobilização social. Com isso, as construções discursivas das histórias em quadrinhos El Eternauta e El Eternauta II, com seus discursos metafóricos, fornecem ao público leitor uma oportunidade de um impulso emancipatório absolutamente fabuloso, num diálogo intenso entre questões existenciais e a cultura política.

Para concluir, pode-se afirmar que a produção quadrinística oesterheldiana cumpre o papel de auxiliar na compreensão da realidade histórica e social, ao analisar conflitos das mais diversas perspectivas (culturais, econômicas, sociais e políticas, por exemplo), num esforço para promover um maior questionamento e reflexão acerca da vida social e política, principalmente. Oesterheld tem, portanto, a preocupação com 0 desenvolvimento de uma consciência moral - e, também, pacifista - de seu público leitor e tenta trabalhar nesse sentido por meio dos roteiros de suas histórias em quadrinhos. Para tanto, o roteirista argentino chega a apresentar aos seus leitores, de modo complexo e sofisticado, por meio das histórias em quadrinhos, a opressão da existência dos indivíduos pertencentes às classes que vivem do trabalho, num terrível quadro social (para esses estratos sociais), além de apresentar uma força irredutível de indignação, que deixa expostas as lutas políticas nas sociedades latino-americanas, por meio dos seus estudos de compreensão acerca dos comportamentos sociais e dos modos de vida dos grupos societários.

Oesterheld e o grupo político-militar Montoneros usavam os discursos visuais e as histórias em quadrinhos como um recurso narrativo e pedagógico, buscando ampliar as possibilidades de trabalho com imagens e textos em conjunto, por vezes ultrapassando as limitações impostas até mesmo aos autores críticos, em função do seu ideário de transformação dos processos e dos valores da sociedade, numa crença na possibilidade da formação de um "novo homem", em uma "nova sociedade", em um novo patamar de consciência moral, o que envolve uma efetiva emancipação dos oprimidos, por meio de novas formas de convivência altruístas e humanizadas. Pois Oesterheld atuou - e continua atuando, por meio das suas obras -, na desconstrução dos padrões sociais autoritários, em favor da construção de 
uma organização social que tem como valores o humanismo e a solidariedade. Seria possível a um roteirista de histórias em quadrinhos ter um objetivo mais nobre? Seria isso possível às próprias histórias em quadrinhos? 


\section{REFERÊNCIAS, MATERIAL QUADRINÍSTICO E BIBLIOGRAFIA COMPLEMENTAR}

\section{Referências}

25ํㅡㄹ ANIVERSARIO del golpe de Estado em ABC Color. ABC Color, Asunción. Disponível em: <http://www.abc.com.py/especiales/25-aniversario-del-golpede-1989/>. Acesso em: 17 nov. 2018.

ALESSANDRI, Ferruccio. Introduzione. In: BONA, Luigi; GIUFFRIDA, Sergio (Ed.). Historietas: storia, personaggi e percorsi del fumetto latinoamericano. Milano: Gabriele Mazzotta, 1997.

ANDAUR, Rodolfo. Narración beligerante. In: RODRÍGUEZ, Javier. Anticristo. Santiago: Metales Pesados, 2017.

APPLEBAUM, Anne. Gulag: uma história dos campos de prisioneiros soviéticos. São Paulo: Ediouro, 2004.

ARENDT, Hannah. Origens do totalitarismo. São Paulo: Companhia das Letras, 1989.

AVILA, Felipe Ricardo. Oesterheld y nuestras invasiones extraterrestres, v. 12. Buenos Aires: Deux gráfica studio, 2007.

AYALA MORA, Enrique. La Represión arroísta: caldo de cultivo de la "Gloriosa". In: CABRERA HANNA, Santiago (Ed.). La Gloriosa, ¿ revolución que no fue? Quito: Corporación Editora Nacional; Universidad Andina Simón Bolivar, 2016.

BALLETTA, Edoardo. How to make a revolution with words (and drawings): history, memory, and identity in Oesterheld's comics. In: CATALACARRASCO, Jorge; DRINOT, Paulo; SCORER, James (Ed.). Comics \& memory in Latin America. Pittsburgh: University of Pittsburgh Press, 2017.

BARBIERI, Daniele. As Linguagens dos quadrinhos. São Paulo: Peirópolis, 2017. 
BARTRA, Armando. Pavane for a deceased comic: decadence, illusions, and demise of an exuberant narrative. In: FERNÁNDEZ L'HOESTE, Héctor; POBLETE, Juan. (Ed.). Redrawing the nation: national identity in Latin/o American comics. New York: Palgrave Macmillan, 2009.

BASTOS, Santiago. Los Actores sociales en una década olvidada. In: BRETT, Roddy. Movimiento social, etnicidad y democratización en Guatemala, 19851996. Guatemala: F\&G, 2006.

BERTH, Christiane. Comics in a revolutionary context: educational campaigns and collective memory in Sandinista Nicaragua. In: CATALÁ-CARRASCO, Jorge; DRINOT, Paulo; SCORER, James (Ed.). Comics \& memory in Latin America. Pittsburgh: University of Pittsburgh Press, 2017.

BONA, Luigi; GIUFFRIDA, Sergio (Ed.). Autori latinoamericani dalla A alla Z. In:___ (Ed.). Historietas: storia, personaggi e percorsi del fumetto latinoamericano. Milano: Gabriele Mazzotta, 1997.

BORGES, Jorge Luis. El Inmortal. Disponível em: <http://actorsstudio.org/web/images/pdf/jorge_luis_borges_el_inmortal.pdf>. Acesso em: 28 jul. 2018.

CAMPOS, Rogério de. Nota da edição brasileira. In: OESTERHELD, Héctor Germán; BRECCIA, Alberto; BRECCIA, Enrique. Che: os últimos dias de um herói. São Paulo: Conrad, 2008.

CATALÁ-CARRASCO, Jorge. Raising the cuban flag: comics, collective memory, and the Spanish-cuban-american. In: DRINOT, Paulo; SCORER, James (Ed.). Comics \& memory in Latin America. Pittsburgh: University of Pittsburgh Press, 2017.

DRINOT, Paulo; SCORER, James. Introduction. In: . DRINOT, Paulo; SCORER, James (Ed.). Comics \& memory in Latin America. Pittsburgh: University of Pittsburgh Press, 2017.

CAVALCANTE NETO, João de Lira. Getúlio: do governo provisório à ditadura do Estado Novo (1930-1945). São Paulo: Companhia das Letras, 2013. 
CENTRO CULTURAL SÃO PAULO. Exposições. Disponível em: < http://centrocultural.sp.gov.br/site/eventos/evento/as-varias-faces-de-hectorgerman-oesterheld-mostra-do-acervo-da-gibiteca-henfil/>. Acesso em: 26. nov. 2018.

COGGIOLA, Oswaldo. Governos militares na América Latina. São Paulo: Contexto, 2001.

COLLIER, Simon; SATER, William. Historia de Chile, 1808-1994. Cambridge University: Madrid, 1998. Sucursal em Espanha.

CUEVAS, Joaquín. La Historieta en Bolivia. Historieta Boliviana. In: La Historieta Latinoamericana, Sonaste Maneco. [S.I.]: La Bañadera del Comic, [entre 2007 e 2018]. (Tomo II: Bolivia - Colombia - Ecuador - Paraguay - Peru - Venezuela).

DEL RÍO GARCIA, Eduardo Humberto. La Historieta en México. In: La Vida de cuadritos. México, D. F.: Grijalbo, 1984.

DÍAZ, Cristian. La Historieta chilena. In: La Historieta Latinoamericana, Sonaste Maneco. [S.I.]: La Bañadera del Comic, [entre 2003 e 2018]. (Tomo I: Cuba Chile - Uruguay).

DORFMAN, Ariel; MATTELART, Armand. Para ler o Pato Donald: comunicação de massa e colonialismo. Rio de Janeiro: Paz e Terra, 1978.

DOUCEY, Bruno. Víctor Jara: não à ditadura. São Paulo: Edições SM, 2009.

DRINOT, Paulo. Cyber-Cuy: remembering and forgetting the peruvian left. In: CATALÁ-CARRASCO, Jorge; DRINOT, Paulo; SCORER, James (Ed.). Comics \& memory in Latin America. Pittsburgh: University of Pittsburgh Press, 2017.

FERNÁNDEZ L'HOESTE, Héctor; POBLETE, Juan. Introduction. In: (Ed.). Redrawing the nation: national identity in Latin/o American comics. New York: Palgrave Macmillan, 2009.

FOSSATI, Franco. II Fumetto argentino. In: BONA, Luigi; GIUFFRIDA, Sergio (Ed.). Historietas: storia, personaggi e percorsi del fumetto latinoamericano. Milano: Gabriele Mazzotta, 1997. 
ROSSO, Nicola. II Fumetto messicano. In: BONA, Luigi; GIUFFRIDA, Sergio (Ed.). Historietas: storia, personaggi e percorsi del fumetto latinoamericano. Milano: Gabriele Mazzotta, 1997.

GAGO, Sebastián Horacio. El Eternauta: el conocimiento, capital definitorio del campo del poder. In: VON SPRECHER, Roberto; REGGIANI, Federico. (Ed.). Héctor Germán Oesterheld: de El Eternauta a Montoneros. Córdoba: Universidad Nacional de Córdoba, 2010.

GALEANO, Eduardo. Negócios livres, gente presa? In: PINSKY, Jaime et al. (Org.). História da América através de textos. São Paulo: Contexto, 2001. (Coleção Textos e Documentos, 4).

GARCÍA, Fernando Ariel. De frente a la esfinge. In: OESTERHELD, Héctor Germán; SOLANO LÓPEZ, Francisco. El Eternauta II: 1976. Buenos Aires: Doedytores, 2012.

GILLESPIE, Richard. Soldados de perón: los montoneros. Buenos Aires: Grijalbo, 1998.

GOCIOL, Judith. Oesterheld. Madrid: Sinsentido, 2007.

ROSEMBERG, Diego. La Historieta argentina: una historia. Buenos Aires: Ediciones de la Flor, 2003.

GUERRA, Diego. II Fumetto venezuelano. In: BONA, Luigi; GIUFFRIDA, Sergio (Ed.). Historietas: storia, personaggi e percorsi del fumetto latinoamericano. Milano: Gabriele Mazzotta, 1997.

GUEVARA, Ernesto. O Socialismo e o homem em Cuba. In: Textos políticos. São Paulo: Global, 2009.

HASSON, Moises. Cómic político en Chile (1858-2016). 150 años de publicaciones de humor, sátira y política. Tebeosfera, set. 2018. Disponível em: $<$ https://revista.tebeosfera.com/documentos/comic_politico_en_chile_18582016._150_anos_de_publicaciones_de_humor_satira_y_politica.html $>$. Acesso em: 3 out. 2018.

Comics en Chile. Catálogo de revistas (1908-2000). Santiago: NautaColecciones, 2014. 
HORKHEIMER, Max; ADORNO, Theodor Wiesengrund. A Indústria cultural - lluminismo como mistificação das massas. In: ADORNO, Theodor Wiesengrund. Indústria cultural e sociedade. São Paulo: Paz e Terra, 2002.

La Industria cultural. llustración como engaño de masas. In:

Trotta, 2009. Dialéctica de la llustración: fragmentos filosóficos. Madrid:

IMAGENS do Estado Novo 1937-1945. Direção: Eduardo Escorel. Produção: Cláudio Kahns. [S.I.: s.n.], 2018. 1 DVD (227m).

INVERNIZZI, Hernán; GOCIOL, Judith. Um golpe a los libros: represión en la cultura durante la última ditadura militar. Buenos Aires: Eudeba, 2003.

LA HORA de los hornos: notas y testimonios sobre el colonialismo, la violencia y la liberación. Direção: Fernando Ezequiel Solanas. Produção: Fernando Ezequiel Solanas. Roteiro: Octavio Getino e Fernando Ezequiel Solanas. Músicas: Fernando Ezequiel Solanas. [S.I.]: Cinesur, [200-].1 DVD (248 min), P\&B.

LÓPEZ ROMERO, Fernando. La FEUE y la Gloriosa. In: CABRERA HANNA, Santiago (Ed.). La Gloriosa, ¿revolución que no fue?. Quito: Corporación Editora Nacional; Universidad Andina Simón Bolivar, 2016.

MARX, Karl. O 18 Brumário e Cartas a Kugelmann. Rio de Janeiro: Paz e Terra, 1969.

Teses sobre Feuerbach. [S.I.]: RocketEdition®, 2005. Disponível em: <http://www.ebooksbrasil.org/adobeebook/feuerbach.pdf>. Acesso em: 21 jul. 2018.

ENGELS, Friedrich. O Capital: crítica da economia política. Livro 1: o processo de produção do capital. São Paulo: Boitempo, 2013.

MILTON, Cynthia. Death in the Andes: comics as means to broach stories of political violence in Peru. In: CATALÁ-CARRASCO, Jorge; DRINOT, Paulo; SCORER, James (Ed.). Comics \& memory in Latin America. Pittsburgh: University of Pittsburgh Press, 2017. 
MOGNO, Dario. II Fumetto cubano. In: BONA, Luigi; GIUFFRIDA, Sergio (Ed.). Historietas: storia, personaggi e percorsi del fumetto latinoamericano. Milano: Gabriele Mazzotta, 1997.

MONTERO, Hugo. Oesterheld, la biografia: viñetas y revolución. Buenos Aires: Sudestada, 2013.

MUÑOZ, José. Carta a Don Héctor. In: MONTERO, Hugo. Oesterheld, la biografia: viñetas y revolución. Buenos Aires: Sudestada, 2013.

MUÑOZ, Pablo. Un Poco de historia. In: OESTERHELD, Héctor Germán; BRECCIA, Alberto. Mort Cinder. Buenos Aires: Diario Clarín, 2004. (Biblioteca Clarín de la Historieta, 13).

NEPOMUCENO, Eric. Nicarágua: um país acossado. Porto Alegre: L\&PM, 1985.

OESTERHELD en tercera persona. Buenos Aires: La Bañadera Del Comic, 2008.

OJEDA, Bernardita. La Dictadura chilena en viñetas. Tebeosfera, set. 2018. Disponível em: $<\mathrm{https}$ ://revista.tebeosfera.com/documentos/la_dictadura_chilena_en_vinetas. html >. Acesso em: 3 out. 2018.

OLMEDO CARRASCO, Carolina. Sobre el dibujo y el relato histórico en Anticristo. In: RODRÍGUEZ, Javier. Anticristo. Santiago: Metales Pesados, 2017.

ORTEGA, Tomás. Oesterheld y Cortázar: primer y último round por la revolución. Tebeosfera, dez. 2017. Disponível em: $<$ https://revista.tebeosfera.com/documentos/oesterheld_y_cortazar_primer_y_ ultimo_round_por_la_revolucion.html>. Acesso em: 12 out. 2018.

PÉREZ-DEL-SOLAR, Pedro. Stories of an invisible war: comics and the peruvian "internal conflict" (1980-2000). International Journal of Comic Art. [S.I.], John Lent, v. 14, n. 1, primavera 2012. 
PIGOZZI, Douglas. V de Vingança e o totalitarismo político: uma crítica contundente ao capitalismo da perspectiva anarquista. 1as. Jornadas Internacionais de Histórias em Quadrinhos, 23 a 26 ago. 2011.

POSTEMA, Barbara. Estrutura narrativa nos quadrinhos: construindo sentido a partir de fragmentos. São Paulo: Peirópolis, 2018.

PRESIDENCIAS EN ARGENTINA. Disponível em: <https://www.sitiosargentina.com.ar/2/presidentes.htm>. Acesso em: 4 dez. 2018.

RAMOS, Paulo. Bienvenido: um passeio pelos quadrinhos argentinos. Campinas, SP: Zarabatana Books, 2010.

REATI, Fernando. Argentina's Montoneros: comics, cartoons, and images as political propaganda in the underground guerrilla press of the 1970s. In: FERNÁNDEZ L'HOESTE, Héctor; POBLETE, Juan. (Ed.). Redrawing the nation: national identity in Latin/o American comics. New York: Palgrave Macmillan, 2009.

RÉNIQUE, José Luis. A Revolução peruana. São Paulo: UNESP, 2009. (Coleção Revoluções do Século 20).

RODAS CHAVES, Germán. Manuel Agustín Aguirre y el socialismo en la Gloriosa. In: CABRERA HANNA, Santiago (Ed.). La Gloriosa, ¿revolución que no fue?. Quito: Corporación Editora Nacional; Universidad Andina Simón Bolivar, 2016.

SACCOMANNO, Guillermo. El Pasado que vuelve. In: OESTERHELD, Héctor Germán; BRECCIA, Alberto. Mort Cinder. Buenos Aires: Diario Clarín, 2004. (Biblioteca Clarín de la Historieta, 13).

SALINAS CAÑAS, Sergio. El Tres letras. Historia y contexto del Movimiento de Izquierda Revolucionaria (MIR). Santiago: RIL, 2013.

SILVA JUNIOR, Gonçalo. A Guerra dos gibis: a formação do mercado editorial brasileiro e a censura aos quadrinhos, 1933-64. São Paulo: Companhia das Letras, 2004. José Luis Salinas: visionário dos quadrinhos. São Paulo: Noir, 2017. 
SOMEILLAN, Yamile Regalado. Visual culture and the new cuban man: examining a core force of the cuban revolution, 1959-1963. International Journal of Comic Art. [S.I.], John Lent, v. 7, n. 2, outono/inverno 2005.

SOTO DÍAZ, Rubén Eduardo. La Historieta Latinoamericana, Sonaste Maneco. [S.I.]: La Bañadera del Comic, [entre 2008 e 2018]. (Tomo IV: México).

TANNENBAUM, Edward. La Experiencia fascista: sociedad y cultura en Italia (1922-1945). Madrid: Alianza Editorial, 1975.

TERÁN, Oscar. Historia de las ideas em la Argentina: diez lecciones iniciales, 1810-1980. Buenos Aires: Siglo Veintiuno, 2010.

VALLADARES, Eduardo; BERBEL, Márcia. Revoluções do século XX. São Paulo: Scipione, 1994.

VALLECILLO, Ernesto. A Educação popular: arma na luta ideológica na Nicarágua. In: BRANDÃO, Carlos (Org.). Lições da Nicarágua: a experiência da esperança. Campinas: Papirus, 1984.

VEGA UGALDE, Silvia. La Gloriosa: "la revolución que pudo haber sido y no fue". In: CABRERA HANNA, Santiago (Ed.). La Gloriosa, ¿revolución que no fue?. Quito: Corporación Editora Nacional; Universidad Andina Simón Bolivar, 2016.

VERGUEIRO, Waldomiro. Histórias em quadrinhos: seu papel na indústria de comunicação de massa. 1985. Dissertação (Mestrado em Ciências da Comunicação)-Escola de Comunicações e Artes, Universidade de São Paulo, 1985. 2017. Pesquisa acadêmica em histórias em quadrinhos. São Paulo: Criativo, . SANTOS, Roberto Elísio dos. (Org.). A Linguagem dos quadrinhos: estudos de estética, linguística e semiótica. São Paulo: Criativo, 2015.

VON SPRECHER, Roberto. Discurso montonero en las historietas de Héctor Germán Oesterheld. Astrolabio. Nueva Época, n. 4, jul. 2007. Disponível em: $<$ https://revistas.unc.edu.ar/index.php/astrolabio/article/view/249/259>. Acesso em: 16 out. 2018. 
. REGGIANI, Federico. (Ed.). Héctor Germán Oesterheld: de EI Eternauta a Montoneros. Córdoba: Universidad Nacional de Córdoba, 2010.

WINN, Peter. A Revolução chilena. São Paulo: UNESP, 2010. (Coleção Revoluções do Século 20).

ZIMMERMANN, Matilde. A Revolução nicaraguense. São Paulo: UNESP, 2006. (Coleção Revoluções do Século 20).

\section{Material quadrinístico}

ARQUIVO DE ILUSTRACIÓN ARGENTINA. Disponível em: <https://ilustracion.fadu.uba.ar/2015/11/08/alberto-broccoli/>. Acesso em: 18 nov. 2018.

. Disponível em: <https://ilustracion.fadu.uba.ar/2016/06/03/revistaskorpio/>. Acesso em: 18 nov. 2108.

BILAL, Enki. O Sono do monstro. In: BILAL, Enki. Tetralogia Monstro. Belo Horizonte: Nemo, 2013.

A Trilogia Nikopol. Belo Horizonte: Nemo, 2012.

BRECCIA, Alberto; SASTURAIN, Juan. Perramus: dente por dente. São Paulo: Globo, 2009.

COUTINHO, Laerte. Ilustração sindical do Laerte. São Paulo: Oboré, 1989. Disponível em: <https://docslide.com.br/documents/guia-de-ilustracaosindical-do-laerte.html>. Acesso em: 20 out. 2018.

DE SANTIS, Pablo. The Fierro years: an exercise in melancholy. In: FERNÁNDEZ L'HOESTE, Héctor; POBLETE, Juan. (Ed.). Redrawing the nation: national identity in Latin/o American comics. New York: Palgrave Macmillan, 2009.

DEL RÍO GARCIA, Eduardo Humberto. El Nuevo comic. La nueva historieta (o algo que puede llamarse "el comic social". In: . La Vida de cuadritos. México, D. F.: Grijalbo, 1984. 
EL DIARIO DEL CUY. Disponível em: <https://elcuy.files.wordpress.com/2018/09/tiras-1416-y-1417-color.jpg>. Acesso em: 17 dez. 2018.

FIGUEROA, Alexis; ROMO, Claudio. Lota, 1960: la huelga larga del carbón. Santiago: LOM, 2015.

FONCUEVA, Miguel Angel; ESCOLA, Manuel. Historietas argentinas en la Biblioteca Nacional: II concurso de historieta. Buenos Aires: Biblioteca Nacional, 2012.

Historietas argentinas en la Biblioteca Nacional: III concurso de historieta. Buenos Aires: Biblioteca Nacional, 2012.

Historietas argentinas en la Biblioteca Nacional: IV concurso de historieta. Buenos Aires: Biblioteca Nacional, 2013.

CATAIFE, Dario. Historietas argentinas en la Biblioteca Nacional: obras selecionadas del V concurso. Buenos Aires: Biblioteca Nacional, 2015.

LARA, María Eugenia. Historieta argentina: I concurso de historieta. Buenos Aires: Biblioteca Nacional, 2010.

GLOBEDIA. El Diario Colaborativo. Disponível em: $<$ http://globedia.com/macrismo-desaparecer-eternauta-hipocresia-aparentepolitica>. Acesso em: 26 nov. 2018.

GUIMARÃES, Bernardo. A Escrava Isaura. São Paulo: Ática, 2010.

HISTORIETECA. Historieta Argentina. Disponível em: <historieteca.com.ar/HGO/hgo.htm>. Acesso em: 20 nov. 2018.

HORA CERO. Buenos Aires: Frontera, n. 11, mar. 1958. Buenos Aires: Frontera, n. 13, maio 1958. 
HORA CERO SUPLEMENTO SEMANAL. Buenos Aires: Frontera, n. 1, set. 1957.

HORA ZERO. Rio de Janeiro: Garimar, ano 1, n.1, 1958.

LATINO WEEKLY REVIEW. Disponível em: <latinoweeklyreview.com/?attachment_id=292726>. Acesso em: 28 nov. 2018.

MARTINI, Claudio Roberto; SASTURAIN, Juan (Org.). Fierro Brasil no 1: antologia de historietas de revista argentina Fierro e quadrinhos brasileiros. Campinas, SP: Zarabatana Books, 2011. . Fierro Brasil no 2: antologia de historietas de revista argentina Fierro e quadrinhos brasileiros. Campinas, SP: Zarabatana Books, 2012.

MOORE, Alan; GIBBONS, Dave. Watchmen. São Paulo: Panini, 2009. LLOYD, David. V de vingança. Barueri, SP: Panini, 2012.

OESTERHELD, Héctor Germán; BRECCIA, Alberto. El Eternauta. Buenos Aires: Ediciones de La Urraca, [19-].

Mort Cinder. Buenos Aires: Diario Clarín, 2004. (Biblioteca Clarín de la Historieta, 13).

Sherlock Time. Buenos Aires: Diario Clarín, 2006. (Nueva Biblioteca Clarín de la Historieta, 7)

BRECCIA, Enrique. Che: os últimos dias de um herói. São Paulo: Conrad, 2008.

DURAÑONA, Leopoldo. Latinoamérica y el imperialismo. 450 años de guerra. Buenos Aires: Doedytores, 2004. 2015. . SOLANO LÓPEZ, Francisco. The Eternaut. Seattle: Fantagraphics, 
. O Eternauta. São Paulo: Martins Fontes, 2011.

. El Eternauta. Barcelona: Clarín, 2000. (Serie Clásicas).

. O Eternauta II. São Paulo: Martins Fontes, 2013.

El Eternauta II: 1976. Buenos Aires. Doedytores, 2012.

. Rolo, el marciano adoptivo. Buenos Aires. La Página, 2009.

TRIGO, Gustavo. La Guerra de los Antartes. Buenos Aires: Colihue, 1998.

PASADO EN LETRAS. Disponível em: < http://www.pasadoenletras.com/2014/04/satiricon-diciembre-de-1975.html>. Acesso em: 18 nov. 2018.

PIÑERICOSAS. The Clinic. Santiago, ano 19, n. 753, jun. 2018.

. The Clinic. Santiago, ano 19, n. 750, jun. 2018.

. The Clinic. Santiago, ano 19, n. 749, maio 2018.

PRADO, Pedro. Santa María 1907: la marcha ha comenzado. Santiago: LOM, 2014.

PRIETO, Jenaro. El Socio. Santiago: Origo, 2017.

QUINO. 10 anos com Mafalda. São Paulo: Martins Fontes, 2010.

Mafalda inédita. São Paulo: Martins Fontes, 2013.

. Toda Mafalda. São Paulo: Martins Fontes, 2010. 
QUINTERNO, Dante Raul. Andanzas de Patoruzú. Santa Fe: Universo, ano LI, n. 825, set. 2007.

. Santa Fe: Universo, ano LVI, n. 904, mar. 2012.

REYES, Carlos; ELGUETA, Rodrigo. Los Años de Allende: novela gráfica. Santiago: Hueders, 2015.

RODRÍGUEZ PINO, Javier. Anticristo. Santiago: Metales pesados, 2017.

SABORIDO, Felix. ¿Donde esta Oesterheld? Revista Feriado Nacional. Buenos Aires, n. 5, out. 1983.

SANZ, Salvador. O Esqueleto: o início. Campinas, SP: Zarabatana Books, 2015.

2016.

. O Esqueleto: o museu esquecido. Campinas, SP: Zarabatana Books, 2016.

. Noturno. Campinas, SP: Zarabatana Books, 2011.

SOLANO LÓPEZ en primera persona. Buenos Aires: Ancares, 2006.

SPIEGELMAN, Art. Maus: a história de um sobrevivente. São Paulo: Companhia das Letras, 2005.

VILLAR, Alfredo; ROSSELL, Luis; COSSIO, Jesús. Sendero Luminoso: história de uma guerra suja. São Paulo: Veneta, 2016.

VON GOETHE, Johann Wolfgang. Fausto em quadrinhos. São Paulo: Peirópolis, 2017. (Clássicos em HQ, 16).

\section{Bibliografia complementar}

1900. Direção: Bernardo Bertolucci. Produção: Alberto Grimaldi. Músicas: Ennio Morricone. Manaus: Sonopress Rimo Indústria e Comércio Fonográfica, [201-?]. 1 DVD (315 min). 
A BATALHA de Argel. Direção: Gillo Pontecorvo. Produção: Saadi Yacef. Música: Ennio Morricone e Gillo Pontecorvo. Manaus: AMZ Mídia Industrial S.A., 2014. 1 DVD (121 min).

ADORNO, Theodor. Crítica cultural e sociedade. In: ADORNO, Theodor. Indústria cultural e sociedade. São Paulo: Paz e Terra, 2002.

. HORKHEIMER, Max. Dialética do esclarecimento: fragmentos filosóficos. Disponível em: $<$ https://nupese.fe.ufg.br/up/208/o/fil_dialetica_esclarec.pdf>. Acesso em: 28 ago. 2018.

ALCONET. Disponível em: <www.alconet.com.ar/varios/libros/ebook_e/El_arbol_de_la_Buena_Muerte.pdf >. Acesso em: 24 out. 2016.

ALLENDE, Isabel. La Casa de los espíritus. Barcelona: Penguin Random House, 2018.

ALMEIDA, Claudio Aguiar. Cultura e sociedade no Brasil: 1940-1968. São Paulo: Atual, 1996.

ALTHUSSER, Louis. Aparelhos ideológicos do estado. Rio de Janeiro: Graal, 1983.

ARRUDA, Marcos. O Desafio da educação popular na Nicarágua. In: BRANDÃO, Carlos (Org.). Lições da Nicarágua: a experiência da esperança. Campinas: Papirus, 1984.

BALSECA, Fernando. Las llusiones vanas en la literatura y la revolución política. In: CABRERA HANNA, Santiago (Ed.). La Gloriosa, ¿revolución que no fue?. Quito: Corporación Editora Nacional; Universidad Andina Simón Bolivar, 2016.

BARONE, Orlando (Org.). Diálogos: Borges / Sabato. São Paulo: Globo, 2005.

BELLOLIO, Cristóbal. ¿Quién es más de izquierda? The Clinic, Santiago, n. 753, p. 19, 2018. 
BENEVIDES, Maria Victoria de Mesquita. O Governo Jânio Quadros. São Paulo: Brasiliense, 1981.

BERARDI, Franco. Genesi e significato del termine "autonomia". In: BIANCHI, Sergio; CAMINITI, Lanfranco (Ed.). Gli Autonomi: le storie, le lotte, le teorie. Roma: DeriveApprodi, 2007, v. II.

BERONE, Lucas. La Intención es joder um poco. Algunas claves de lectura sobre la obra de Carlos Trillo. In: GAGO, Sebastián Horacio; LOMSACOV, Pablo Iván (Ed.). Viñetas bajo la lupa: algunas claves de lectura sobre historieta argentina. Córdoba: Universidad Nacional de Córdoba, 2018.

BIANCHI, Sergio; CAMINITI, Lanfranco (Ed.). Gli Autonomi: le storie, le lotte, le teorie. Roma: DeriveApprodi, 2007, v. I.

Avvertenze ala lettura. In: (Ed.). Gli Autonomi: le storie, le lotte, le teorie. Roma: DeriveApprodi, 2007, v. II.

BONA, Luigi; GIUFFRIDA, Sergio (Ed.). Historietas: storia, personaggi e percorsi del fumetto latinoamericano. Milano: Gabriele Mazzotta, 1997.

BOND, Rosana. Peru: do império dos incas ao império da cocaína. Rio de Janeiro: COEDITA-Cooperativa de trabalhadores em produção cultural e editorial, 2004.

BORGES, Jorge Luis. Ficciones. Madrid: Alianza Editorial, 1993.

BRETT, Roddy. Movimiento social, etnicidad y democratización en Guatemala, 1985-1996. Guatemala: F\&G, 2006.

BUADES, Josep. A Guerra civil espanhola. São Paulo: Contexto, 2013.

CABRERA HANNA, Santiago. Introducción. In: CABRERA HANNA, Santiago (Ed.). La Gloriosa, ¿revolución que no fue?. Quito: Corporación Editora Nacional; Universidad Andina Simón Bolivar, 2016.

CAMPOS, Haroldo de. Deus e o diabo no Fausto de Goethe: marginália fáustica. São Paulo: Perspectiva, 2005. 
CAMPOS, Raymundo Carlos Bandeira. História da América. São Paulo: Atual, 1991.

CARRÁ, Juan. Héctor Germán Oesterheld: vida y obra de um militante. Héctor Oesterheld. Disponível em: <http://www.elortiba.org/etern1.html>. Acesso em: 13 jul. 2016.

CASTELLANO, Lucio. II Rifiuto del lavoro. In: BIANCHI, Sergio; CAMINITI, Lanfranco (Ed.). Gli Autonomi: le storie, le lotte, le teorie. Roma: DeriveApprodi, 2007, v. II.

CASTORIADIS, Cornelius. Os Destinos do totalitarismo \& outros escritos. Porto Alegre: L\&PM, 1985.

Uma Sociedade à deriva: entrevistas e debates - 1974 - 1997. Aparecida, SP: Ideias \& Letras, 2006.

CAVALCANTE NETO, João de Lira. Getúlio: da volta pela consagração popular ao suicídio (1945-1954). São Paulo: Companhia das Letras, 2014.

CIRNE, Moacy. A Escrita dos quadrinhos. Natal: Sebo Vermelho, 2005.

COLMÁN GUTIÉRREZ; GOIRIZ, Roberto. La Historieta en Paraguay. Una mirada al humor gráfico y la historieta en Paraguay. In: La Historieta Latinoamericana, Sonaste Maneco. [S.I.]: La Bañadera del Comic, [entre 2007 e 2018]. (Tomo II: Bolivia - Colombia - Ecuador - Paraguay - Peru Venezuela).

COSSE, Isabella. Mafalda: talisman of democracy and icon of nostalgia for the 1960s. In: CATALÁ-CARRASCO, Jorge; DRINOT, Paulo; SCORER, James (Ed.). Comics \& memory in Latin America. Pittsburgh: University of Pittsburgh Press, 2017.

DORATIOTO, Francisco Fernando Monteoliva; DANTAS FILHO, José. De Getúlio a Getúlio: o Brasil de Dutra a Vargas, 1945 a 1954. São Paulo: Atual, 1991.

DORFMAN, Ariel. O Longo adeus a Pinochet. São Paulo: Companhia das Letras, 2003. 
DRAPER, Bram. Sandino and other superheroes: the function of comic book in revolutionary Nicaragua. International Journal of Comic Art. [S.I.], John Lent, v. 11, n. 2, outono 2009.

EL ESTADO de excepción, Columba, las políticas y Oesterheld. Disponível em: <unmalpensado.blogspot.com/2012/06/el-estado-de-excepcion-columbalas.htm/>. Acesso em: 26 jun. 2018.

EL SIGLO. Disponível em: <http://www.elsiglo.cl/>. Acesso em: 9 jul. 2018.

ETERNAUTA. Disponível em: <www.eternauta.com>. Acesso em: 24 out. 2016.

FERNANDES, Geisa. 50 anos do golpe militar no Brasil: o que as histórias em quadrinhos têm a ver com isso? 3as. Jornadas Internacionais de Histórias em Quadrinhos, 18 a 21 ago. 2015.

FERNÁNDEZ, Laura Cristina. El Discurso estético-militante como pérdida del aura en la obra y el autor. Los casos de las historietas La Guerra de los Antartes y Camote. In: GAGO, Sebastián Horacio; LOMSACOV, Pablo Iván (Ed.). Viñetas bajo la lupa: algunas claves de lectura sobre historieta argentina. Córdoba: Universidad Nacional de Córdoba, 2018.

Historieta y resistencia: arte y política en Oesterheld (1968-1978). Mendoza: Editorial de la Universidad Nacional de Cuyo, EDIUNC, 2012.

. GAGO, Sebastián Horacio. Historieta y mitos políticos: la relectura oficial de El Eternauta em la Argentina democrática. Disponível em: $<$ https://revistas.udem.edu.co/index.php/anagramas/article/view/610/551>. Acesso em: 26 jun. 2018.

FERNÁNDEZ, Patricio. El Mapa político está desteñido. The Clinic, Santiago, n. 750, p. 5, 2018.

FERNÁNDEZ L'HOESTE, Héctor. De Oesterheld o las trampas identitarias del nacionalismo. Nona arte: revista brasileira de pesquisas em histórias em quadrinhos, São Paulo, v. 1, n.1, 2012. Disponível em: < http://www2.eca.usp.br/nonaarte/ojs/index.php/nonaarte/article/view/1/3>. Acesso em: 17 jul. 2018. 
FICO, Carlos. Ainda à espera da verdade e justiça. Carta na escola, São Paulo, n. 76, p. 41-45, maio 2013.

FONCUEVA, Miguel Angel. Para ler Oesterheld+Eternauta. Buenos Aires: [s.n.], 2018.

FOSTER, David William. Masculinity as privileged human agency in $\mathrm{H}$. G. Oesterheld's El Eternauta. In: . El Eternauta, Daytripper, and beyond: graphic narrative in Argentina and Brazil. Austin: University of Texas Press, 2016. cap. 1.

FRANCO, Fernando; OSTUNI, Hernán. La Historieta en Peru. La Historieta en el Perú. In: La Historieta Latinoamericana, Sonaste Maneco. [S.I.]: La Bañadera del Comic, [entre 2007 e 2018]. (Tomo II: Bolivia - Colombia - Ecuador Paraguay - Peru - Venezuela).

FUNDACIÓN VÍCTOR JARA. Disponível em: <www.fundacionvictorjara.org/>. Acesso em: 7 nov. 2018.

GAGO, Sebastián Horacio. "Es la historia de un perseguido político": la lectura del Eternauta entre los jóvenes del siglo XXI. In: . LOMSACOV, Pablo Iván (Ed.). Viñetas bajo la lupa: algunas claves de lectura sobre historieta argentina. Córdoba: Universidad Nacional de Córdoba, 2018.

- Sesenta años de lecturas de Oesterheld. Córdoba: Escuela de Ciencias de la Información, 2015.

GARCÍA, Facundo. Héctor fue un hombre que necessitava creer en la vida. Héctor Oesterheld. Disponível em: <http://www.elortiba.org/etern1.html>. Acesso em: 15 jul. 2016.

GARCÍA MÁRQUEZ, Gabriel. Doze contos peregrinos. Rio de Janeiro: Record, 2011.

GUEVARA, Ernesto. El Diario del Che em Bolivia. Buenos Aires: América Latina, 1973.

. Textos políticos. São Paulo: Global, 2009. 
. Textos revolucionários. São Paulo: Global, 2009.

HÉCTOR OESTERHELD. Disponível em: <http://www.elortiba.org/etern1.html>. Acesso em: 13 jul. 2016.

HINOJOSA, Hugo. Entre el pasado y el futuro. Cómic chileno y contracultura (1984-1990). Tebeosfera, set. 2018. Disponível em: <https://revista.tebeosfera.com/documentos/entre_el_pasado_y_el_futuro._co mic_chileno_y_contracultura_1984-1990.html >. Acesso em: 3 out. 2018.

IBARRA, Hernán. ¿Qué fue la revolución de 1944? In: CABRERA HANNA, Santiago (Ed.). La Gloriosa, ¿revolución que no fue?. Quito: Corporación Editora Nacional; Universidad Andina Simón Bolivar, 2016.

JAGUAR; AUGUSTO, Sergio (Org.). O Pasquim: antologia 1972-1973: número 150 ao 200. Rio de Janeiro: Desiderata, 2007, v. 2.

. (Org.) O Pasquim: antologia 1969-1971: número 1 ao 150. Rio de Janeiro: Desiderata, 2006, v. 1.

KOSHIBA, Luiz; PEREIRA, Denise Manzi Frayze. Américas: uma introdução histórica. São Paulo: Atual, 1992.

LEÓN GALARZA, Catalina. Las Mujeres y la "Gloriosa": mayo de 1944. In: CABRERA HANNA, Santiago (Ed.). La Gloriosa, ¿revolución que no fue?. Quito: Corporación Editora Nacional; Universidad Andina Simón Bolivar, 2016.

LUKÁCS, Georg. Existencialismo ou marxismo. São Paulo: Livraria Editora Ciências Humanas, 1979.

LUNA, Félix. Argentina: de Perón a Lanusse (1943-1973). Rio de Janeiro: Civilização Brasileira, 1974.

. Breve história dos argentinos. Rio de Janeiro: Instituto Cultural BrasilArgentina, 1995.

MAGALHÃES, Mário. Marighella: o guerrilheiro que incendiou o mundo. São Paulo: Companhia das Letras, 2012. 
MARCONDES, Ciro Inácio. A Importância histórica e estética dos quadrinhos de guerra. Dois casos: Harvey Kurtzman e Héctor Oesterheld. 1as. Jornadas Internacionais de Histórias em Quadrinhos, 23 a 26 ago. 2011.

MARNY, Jacques. Sociologia das histórias aos quadradinhos. Porto: Livraria Civilização Editora, 1970.

MARX, Karl: ENGELS, Friedrich. Contribuição à crítica da economia política. São Paulo: Folha de São Paulo, 2015. (Coleção Folha. Grandes nomes do pensamento, 22). Manifesto comunista. São Paulo: Escala, 2007.

MAZUR, Dan; DANNER, Alexander. The International graphic novel. In: TABACHNICK, Stephen (Ed.). The Cambridge companion to the graphic novel. Cambridge: Cambridge University, 2017.

. Quadrinhos: história moderna de uma arte global. De 1968 até os dias de hoje. São Paulo: Martins Fontes, 2014.

MENDOZA ZAMBRANO, Mario. Buda Blues. Barcelona: Seix Barral, 2010. Satanás: perfil de un asesino. Barcelona: Seix Barral, 2008.

MERINO, Ana. El Cómic hispânico. Madrid: Cátedra, 2003.

MIANI, Rozinaldo Antonio. Charge: uma prática discursiva e ideológica. Nona arte: revista brasileira de pesquisas em histórias em quadrinhos, São Paulo, v. 1, $\quad$ n.1, 2012. Disponível em: http://www2.eca.usp.br/nonaarte/ojs/index.php/nonaarte/article/view/3/7>. Acesso em: 17 jul. 2018.

MILIBAND, Ralph. Socialismo \& ceticismo. São Paulo: Fundação Editora da UNESP, 2000.

MILIUCCI, Vincenzo; PACCINO, Sirio; PIFANO, Daniele. Autonomia operaia: ieri e oggi. In: BIANCHI, Sergio; CAMINITI, Lanfranco (Ed.). Gli Autonomi: le storie, le lotte, le teorie. Roma: DeriveApprodi, 2007, v. II. 
MOGNO, Darío. La Historieta cubana. In: La Historieta Latinoamericana, Sonaste Maneco. [S.I.]: La Bañadera del Comic, [entre 2003 e 2018]. (Tomo I: Cuba - Chile - Uruguay).

MONCAYO, Patricio. Identificación, representación o sustitución en la disputa de la "Gloriosa". In: CABRERA HANNA, Santiago (Ed.). La Gloriosa, ¿revolución que no fue?. Quito: Corporación Editora Nacional; Universidad Andina Simón Bolivar, 2016.

MORA BORDEL, Javier. A través de la palavra: de Kirk a Sinner (tradición y renovación a la hora de escribir tebeos). Tebeosfera. Tebeoteca: Documentos. Disponível em: <https://www.tebeosfera.com/1/Documento/Articulo/Guionistas/DeKirk/aSinne r.htm>. Acesso em: 21 out. 2018.

H.G.O. Tebeosfera. Tebeoteca: Documentos. Disponível em: $<$ https://www.tebeosfera.com/1/Documento/Articulo/Argentina/Oesterheld.htm >. Acesso em: 9 mar. 2018.

MORAES, Dênis de. O Rebelde do traço: a vida de Henfil. Rio de Janeiro: José Olympio, 1997.

MOREANO, Alejandro. Ecuador, pasado y presente. Quito: Editorial Alberto Crespo Encalada, 1983.

MUSEO de la historieta de Chile. Disponível em: $<$ https://museodelahistorietadechile.wordpress.com/2013/08/21/la-historietadurante-la-unidad-popular>. Acesso em: 2 jan. 2018.

NERUDA, Pablo. Os Comunistas. Disponível em: < http://www.citador.pt/textos/os-comunistas-pablo-neruda>. Acesso em: 4 set. 2018.

Navegações e regressos. São Paulo: MEDIAfashion, 2012.

Últimos poemas: (O Mar e os sinos). Porto Alegre, RS: L\&PM, 2017. (Coleção L\&PM POCKET, 60).

OESTERHELD, Héctor Germán. Doutor ratinho. São Paulo: Melhoramentos, [entre 1958 e 1965]. (Coleção Reino Encantado, 5). 
. Eram três amigos. São Paulo: Martins Fontes, 2012.

O Galinho valente. São Paulo: Melhoramentos, [entre 1958 e 1965]. (Coleção Reino Encantado, 3).

. Una muerte. In: . "Una muerte" y "Hagan juego", en Más allá de Gelo. Buenos Aires: Planeta, 2014. Disponível em: $<$ http://planlectura.educ.ar/wp-content/uploads/2016/01/PresentesH\%C3\%A9ctor-Germ\%C3\%A1n-Oesterheld.pdf>. Acesso em: 29 jul. 2018.

OESTERHELD en primera persona. Buenos Aires: La Bañadera Del Comic, 2005.

OS ANOS de Chumbo. Direção: Margarethe von Trotta. [S.I.: s.n.], 1981. (106 $\min$.).

OSTUNI, Hernán. La Historieta en Bolivia. La Historieta en los diarios. In: La Historieta Latinoamericana, Sonaste Maneco. [S.I.]: La Bañadera del Comic, [entre 2007 e 2018]. (Tomo II: Bolivia - Colombia - Ecuador - Paraguay - Peru - Venezuela).

La Historieta en Colombia. La Historieta colombiana. In: La Historieta Latinoamericana, Sonaste Maneco. [S.I.]: La Bañadera del Comic, [entre 2007 e 2018]. (Tomo II: Bolivia - Colombia - Ecuador - Paraguay - Peru Venezuela).

La Historieta en Ecuador. Apuntes para una historia del cómic en Ecuador. In: La Historieta Latinoamericana, Sonaste Maneco. [S.I.]: La Bañadera del Comic, [entre 2007 e 2018]. (Tomo II: Bolivia - Colombia Ecuador - Paraguay - Peru - Venezuela).

. La Historieta Uruguaya. In: La Historieta Latinoamericana, Sonaste Maneco. [S.I.]: La Bañadera del Comic, [entre 2003 e 2018]. (Tomo I: Cuba Chile - Uruguay).

PACHECO, Eliezer. O Partido Comunista Brasileiro (1922-1964). São Paulo: Alfa-Omega, 1984. 
PIGOZZI, Douglas. El Eternauta II e a semiótica de Peirce. Imaginário!, João Pessoa, n.12, jun. $2017 . \quad$ Disponível em: $<$ marcadefantasia.com/revistas/imaginario/imaginario-11-20/imaginario12/imaginario-12-online.html>. Acesso em: 30 jun. 2017.

As Histórias em quadrinhos e a consciência crítica acerca do autoritarismo na América Latina: O Eternauta II. Imaginário!, João Pessoa, n. 14, jun. 2018.2 Disponível em: <http://marcadefantasia.com/revistas/imaginario/imaginario1120/imaginario14/imaginario14.html>. Acesso em: 24 jun. 2018.

O Papel do poder político na obra "O Eternauta", de Oesterheld e Solano López. 3as. Jornadas Internacionais de Histórias em Quadrinhos, 18 a 21 ago. 2015.

Quadrinhos e totalitarismo: V de Vingança, Watchmen e El Eternauta. João Pessoa: Marca de Fantasia, 2017. (Série Quiosque, 47).

Quadrinhos em ambientes totalitários: contextos históricos. 2as. Jornadas Internacionais de Histórias em Quadrinhos, 20 a 23 ago. 2013.

FONCUEVA, Miguel Angel. Os roteiros de Oesterheld e sua renovação do meio quadrinístico argentino. 5as. Jornadas Internacionais de Histórias em Quadrinhos, 22 a 24 ago. 2018.

POBLETE, Juan. Condorito, chilean popular culture and the work of mediation. In: FERNÁNDEZ L'HOESTE, Héctor; POBLETE, Juan. (Ed.). Redrawing the nation: national identity in Latin/o American comics. New York: Palgrave Macmillan, 2009.

PRIETO, Jenaro. El Socio. [S.I.]: Sociedad Chilena de Ediciones, [19-?].

RAMOS, Paulo. A Leitura dos quadrinhos. São Paulo: Contexto, 2009.

REATI, Fernando. Argentina's Montoneros: comics, cartoons, and images as political propaganda in the underground guerrilla press of the 1970s. In: FERNÁNDEZ L'HOESTE, Héctor; POBLETE, Juan. (Ed.). Redrawing the nation: national identity in Latin/o American comics. New York: Palgrave Macmillan, 2009. 
REP, Miguel. Un ejemplo de fortaleza. Héctor Oesterheld. Disponível em: $<$ http://www.elortiba.org/etern1.html>. Acesso em: 15 jul. 2016.

RIVAS, Manuel. El desaparecido HGO (una historia argentina). Héctor Oesterheld. Disponível em: <http://www.elortiba.org/etern1.html>. Acesso em: 15 jul. 2016.

RODRíGUEZ, Edixon. La Historieta en Venezuela. Historia del comic en Venezuela. In: La Historieta Latinoamericana, Sonaste Maneco. [S.I.]: La Bañadera del Comic, [entre 2007 e 2018]. (Tomo II: Bolivia - Colombia Ecuador - Paraguay - Peru - Venezuela).

ROSSO, Nicola. II Fumetto colombiano. In: BONA, Luigi; GIUFFRIDA, Sergio (Ed.). Historietas: storia, personaggi e percorsi del fumetto latinoamericano. Milano: Gabriele Mazzotta, 1997.

SACCOMANNO, Guillermo; TRILLO, Carlos. Historia de la historieta argentina. Buenos Aires: Record, 1980.

SAGÁSTEGUI, Carla. Acevedo and his predecessor. In: FERNÁNDEZ L'HOESTE, Héctor; POBLETE, Juan. (Ed.). Redrawing the nation: national identity in Latin/o American comics. New York: Palgrave Macmillan, 2009.

SÁNCHEZ, Juan José. Sentido y alcance de dialectica de la llustración. In: HORKHEIMER, Max; ADORNO, Theodor Wiesengrund. Dialéctica de la Ilustración. Madridd: Trotta, 2009. (Colección Estructuras y Procesos).

SANCHEZ PUYOL, Héctor. $O$ Coelhinho preguiçoso. São Paulo: Melhoramentos, [entre 1958 e 1965]. (Coleção Reino Encantado, 8).

SANTAYANA, Mauro. Tragédia Argentina - poder e violência de Rosas ao peronismo. In: PINSKY, Jaime et al. (Org.). História da América através de textos. São Paulo: Contexto, 2001. (Coleção Textos e Documentos, 4).

SASTURAIN, Juan. El Aventurador: una lectura de Oesterheld. Buenos Aires: Aquilina, 2010.

SÉMELIN, Jacques. Purificar e destruir: usos políticos dos massacres e dos genocídios. Rio de Janeiro: DIFEL, 2009. 
SIGAL, Silvia; VERÓN, Eliseo. Peron o muerte: los fundamentos discursivos del fenómeno peronista. Buenos Aires: Legasa, 1986.

SIGOT, Matías. Manchas de tinta: "Ficciones fundacionales" e historieta patagónica. In: GAGO, Sebastián Horacio; LOMSACOV, Pablo Iván (Ed.). Viñetas bajo la lupa: algunas claves de lectura sobre historieta argentina. Córdoba: Universidad Nacional de Córdoba, 2018.

SILES, Jorge. La Historieta en Bolivia. Ultimos años. In: La Historieta Latinoamericana, Sonaste Maneco. [S.I.]: La Bañadera del Comic, [entre 2007 e 2018]. (Tomo II: Bolivia - Colombia - Ecuador - Paraguay - Peru Venezuela).

SILVA JUNIOR, Amaury Fernandes da. Notas biográficas sobre Oesterheld. 5as. Jornadas Internacionais de Histórias em Quadrinhos, 22 a 24 ago. 2018.

SOUZA, Alex de. Moacy Cirne: o gênio criativo dos quadrinhos. Nova Iguaçu, RJ: Marsupial, 2015.

TOLEDO, Caio Navarro de. O Governo Goulart e o golpe de 64. São Paulo: Brasiliense, 1994.

TOTA, Antonio Pedro. O Estado Novo. São Paulo: Brasiliense, 1987.

V de vingança. Direção: Natalie Portman; Hugo Weaving. Produção: Silver Pictures. Música: Dario Marianelli. Manaus: AMZ Mídia Industrial S.A., 2012. 1 DVD (132 min).

VAZQUEZ, Laura. Mort Cinder. Memorias en conflicto. Tebeosfera. Seção: Argentina en cuadritos/1. Disponível em: < https://www.tebeosfera.com/1/Seccion/AEC/01/MortCinder.htm>. Acesso em: 21 out. 2018.

El Silencio de la industria editorial argentina en la producción de revistas de historietas. Tebeosfera. Seção: Argentina en cuadritos/6. Disponível em: < https://www.tebeosfera.com/1/Seccion/AEC/06/Revistas.htm>. Acesso em: 21 out. 2018. 
. Tiempos dorados: Estado, industria y mercado em la historieta argentina. 1as. Jornadas Internacionais de Histórias em Quadrinhos, 23 a 26 ago. 2011.

VERGUEIRO, Waldomiro. Alberto Breccia, mestre latino-americano dos quadrinhos. Jornal Graphiq, Suzano, n. 32, p. 6-7, ago. 2009.

Alberto Breccia, mestre latino-americano dos quadrinhos - parte 2. Jornal Graphiq, Suzano, n. 33, p. 6-7, set. 2009.

Alberto Breccia, mestre latino-americano dos quadrinhos - parte 3. Jornal Graphiq, Suzano, n. 34, p. 6-7, out. 2009.

Brazilian comics: origin, development, and future trends. In: FERNÁNDEZ L'HOESTE, Héctor; POBLETE, Juan. (Ed.). Redrawing the nation: national identity in Latin/o American comics. New York: Palgrave Macmillan, 2009.

Considerazioni sul fumetto brasiliano e stato delle cose. In: BONA, Luigi; GIUFFRIDA, Sergio (Ed.). Historietas: storia, personaggi e percorsi del fumetto latinoamericano. Milano: Gabriele Mazzotta, 1997.

I I am just a comic book reader who became curious.... International Journal of Comic Art. [S.I.], John Lent, v. 18, n. 2, outono/inverno 2016.

Oesterheld e a aventura nos quadrinhos. Jornal Graphiq, Suzano, n. 11, p. 6-7, out. 2007.

Oesterheld e a aventura nos quadrinhos: 2․․ parte. Jornal Graphiq, Suzano, n. 12, p. 6-7, nov. 2007. Peirópolis, 2017.

Panorama das histórias em quadrinhos no Brasil. São Paulo:

PIGOZZI, Douglas. Histórias em quadrinhos como suporte pedagógico: o caso Watchmen. Comunicação \& Educação. Revista do Departamento de Comunicação e Artes da ECA/USP, São Paulo, ano XVIII, n. I, p. 35-42, jan/jun 2013. 
. RAMOS, Paulo; CHINEN, Nobu. Os Pioneiros no estudo de quadrinhos no Brasil. São Paulo: Criativo, 2013.

. SANTOS, Roberto Elísio dos. (Org.). A História em quadrinhos no Brasil. São Paulo: Laços, 2011.

VIDAL, YOSA. Encuentros y desencuentros de Oesterheld en Chile. Tebeosfera, set. 2018.2 Disponível em: $<\mathrm{https}: / /$ revista.tebeosfera.com/documentos/encuentros_y_desencuentros_d e_oesterheld_en_chile.html>. Acesso em: 3 out. 2018.

VON GOETHE, Johann Wolfgang. Fausto: uma tragédia. São Paulo: Ed. 34, 2011, v. I-II.

VON SPRECHER, Roberto. A Diego Cortés. In: GAGO, Sebastián Horacio; LOMSACOV, Pablo Iván (Ed.). Viñetas bajo la lupa: algunas claves de lectura sobre historieta argentina. Córdoba: Universidad Nacional de Córdoba, 2018.

¿Cómo estudiamos la historieta argentina? In: GAGO, Sebastián Horacio; LOMSACOV, Pablo Iván (Ed.). Viñetas bajo la lupa: algunas claves de lectura sobre historieta argentina. Córdoba: Universidad Nacional de Córdoba, 2018.

ZOLBERG, Vera. Para uma sociologia das artes. São Paulo: Senac, 2006. 